
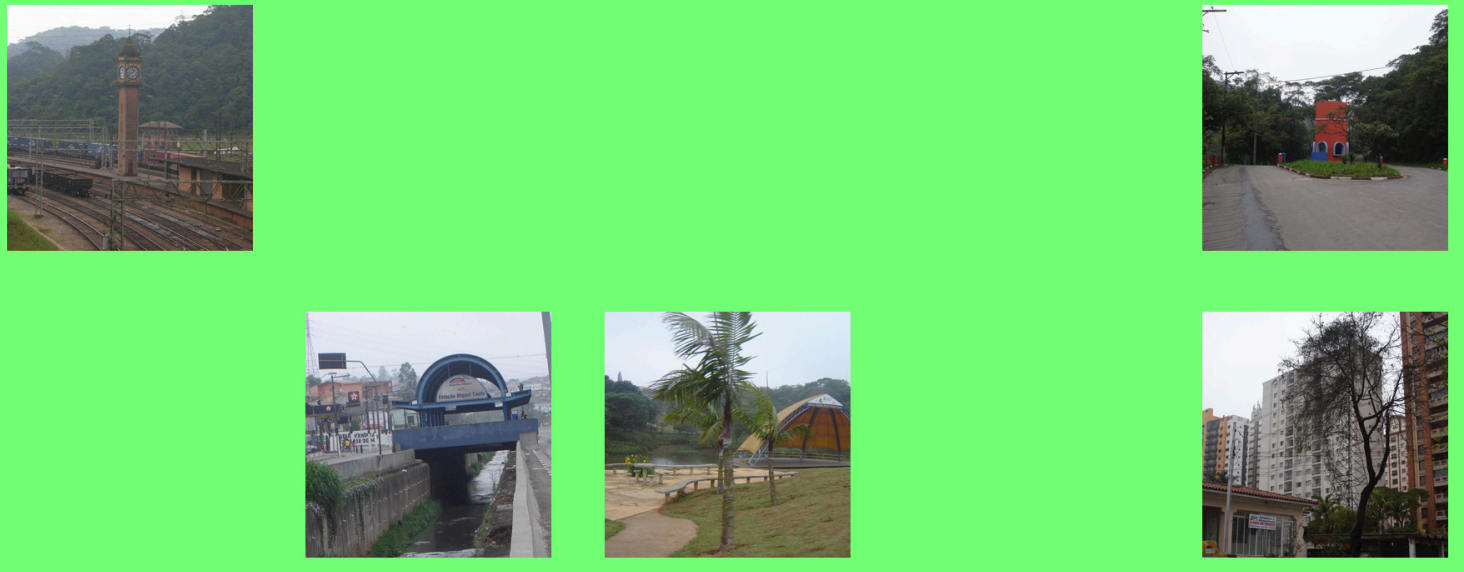

a participação em conselhos como instrumento de gestão municipal
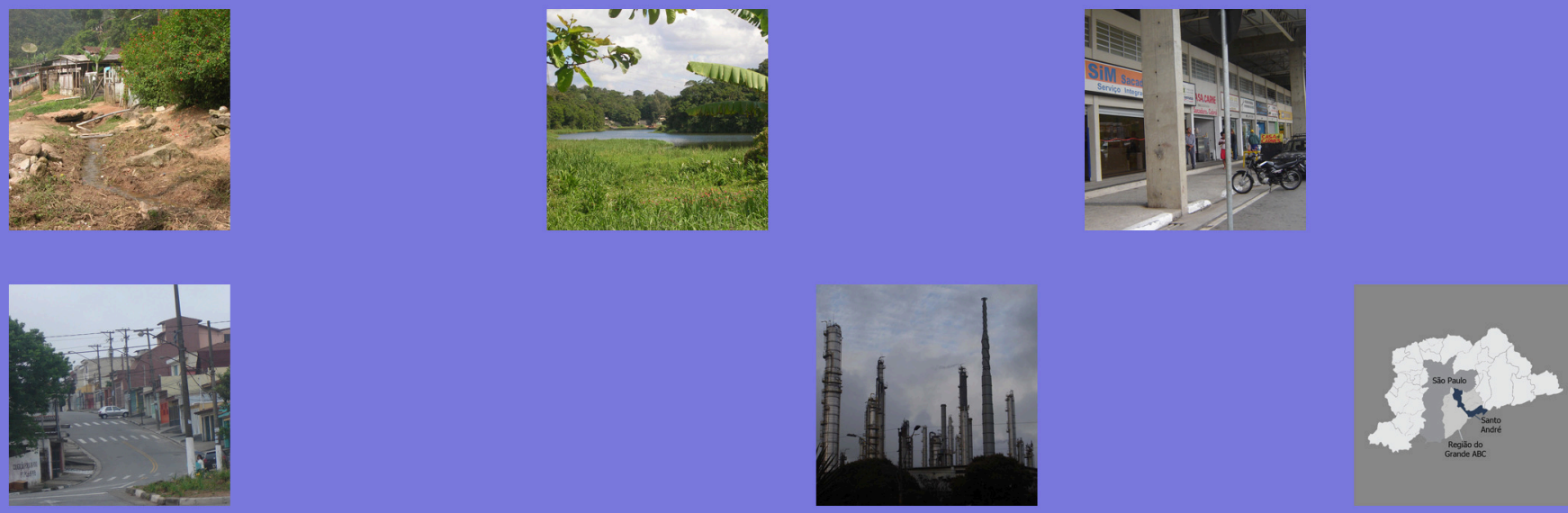

Paula Raquel da Rocha Jorge Vendramini 


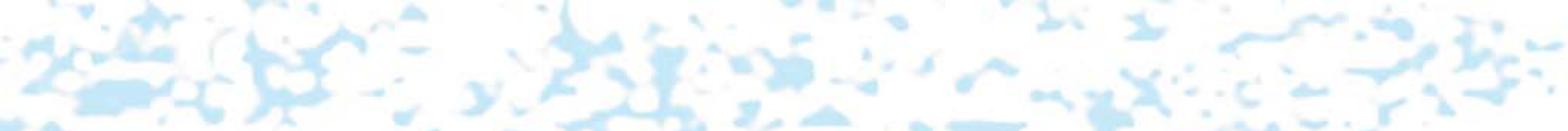

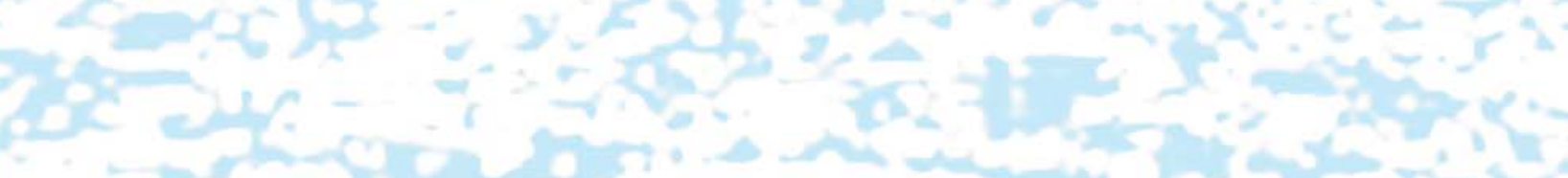

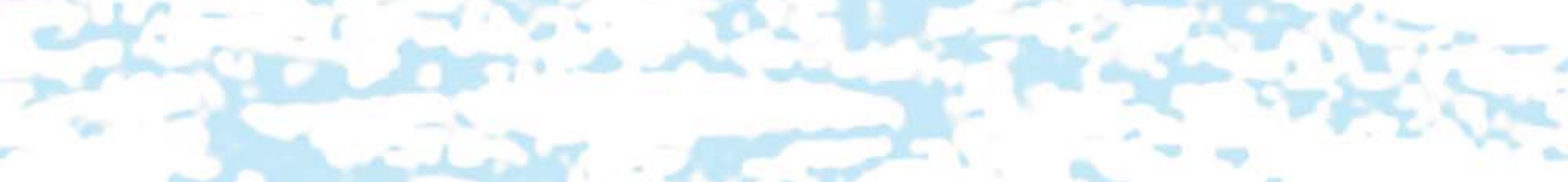

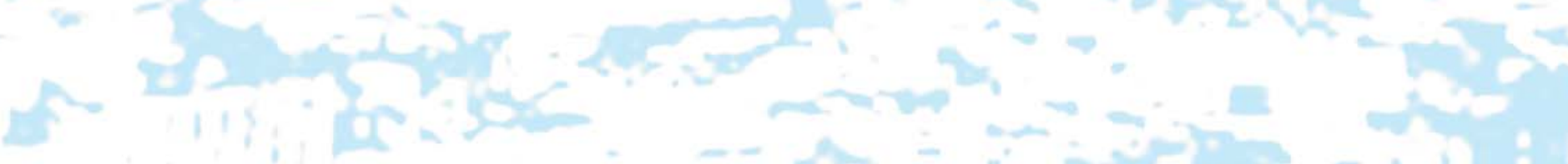

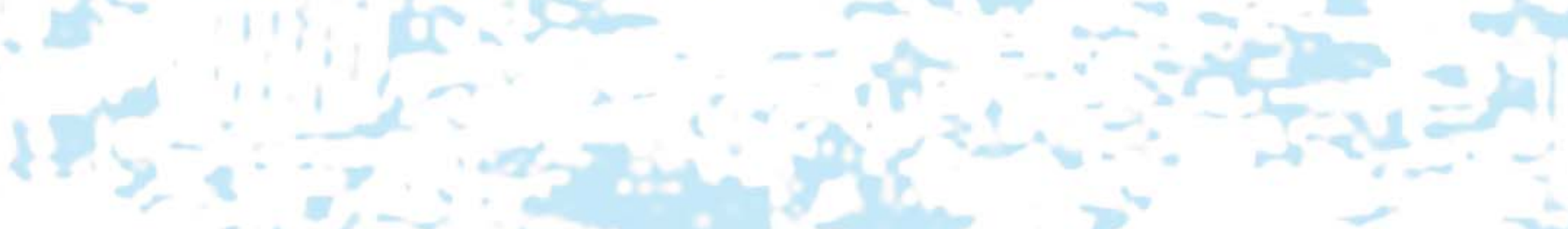

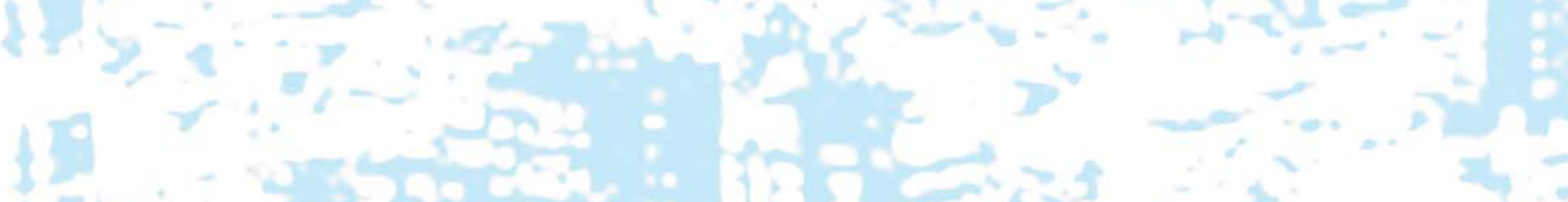
is of hom

ar

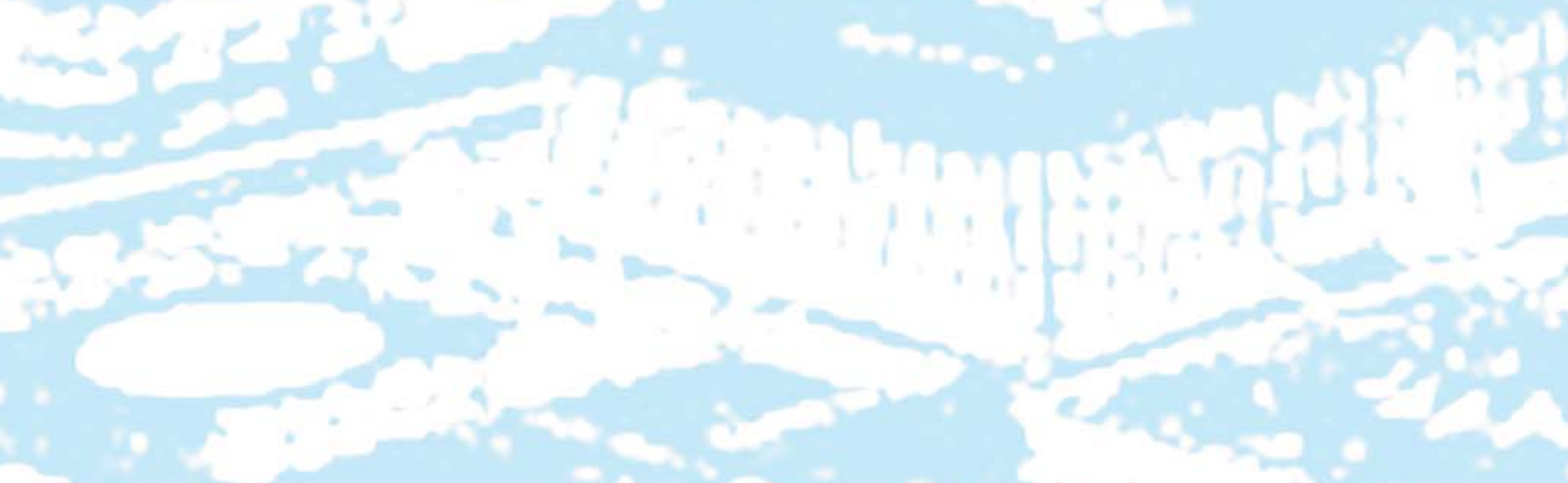

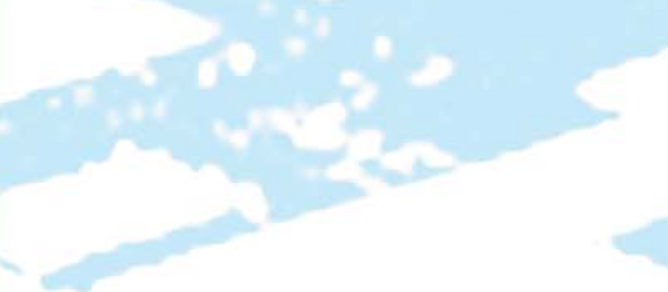

30
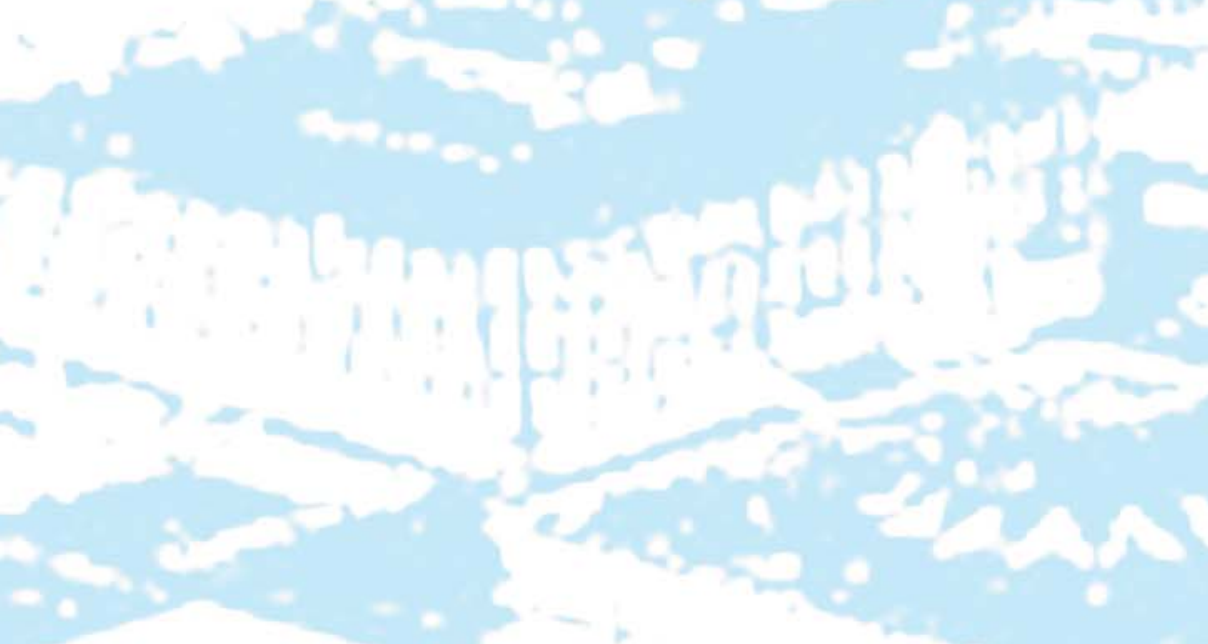

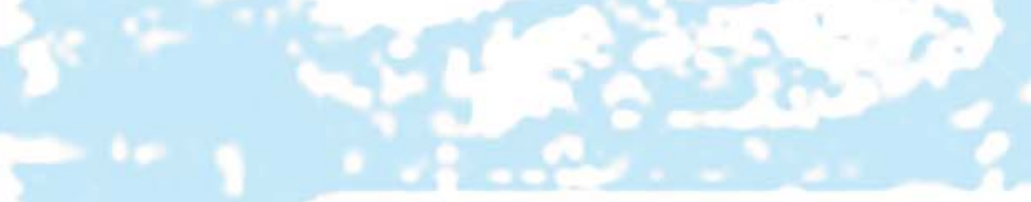

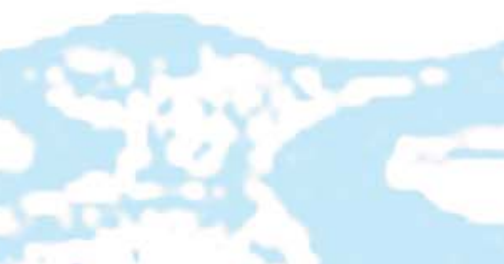

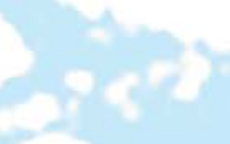

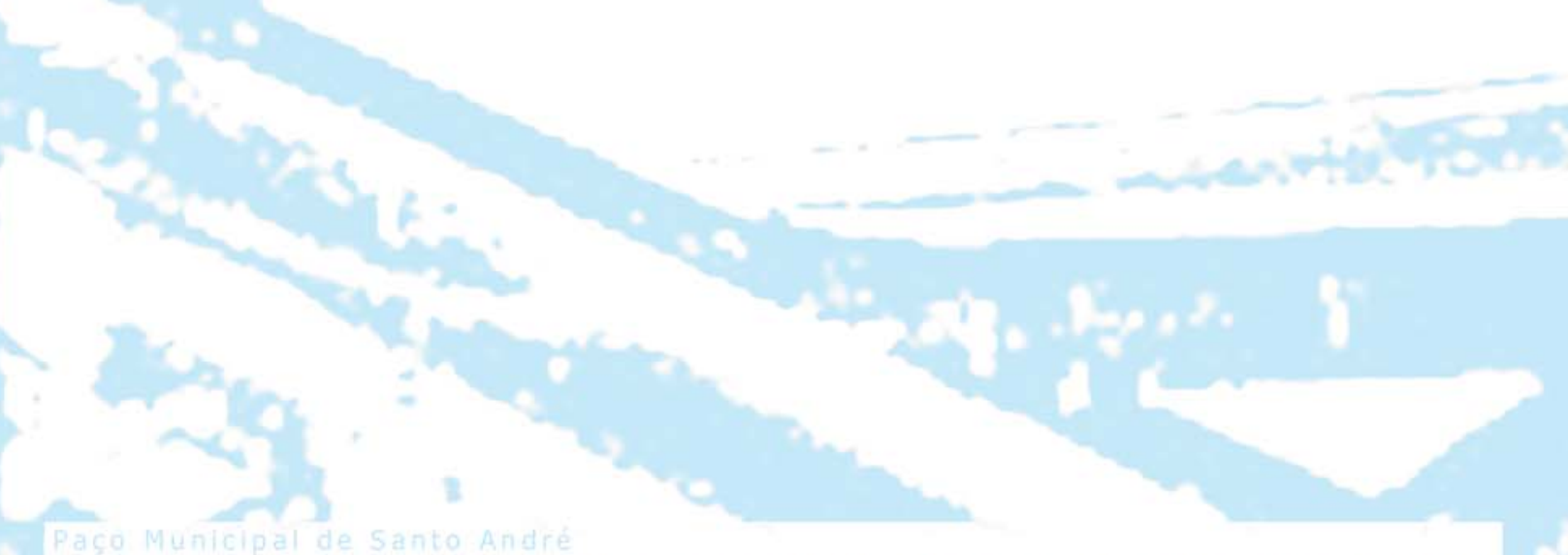

anaters 


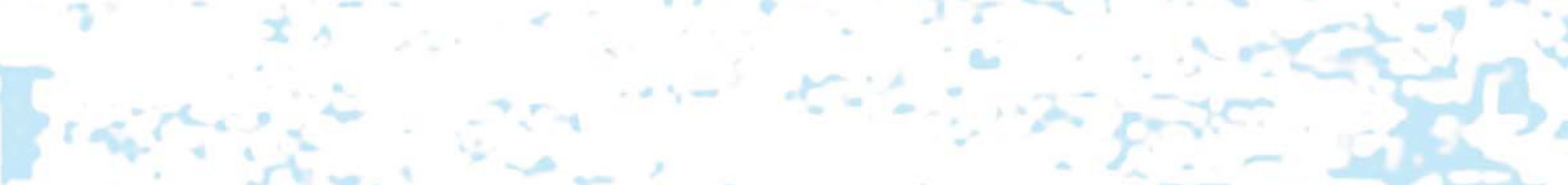

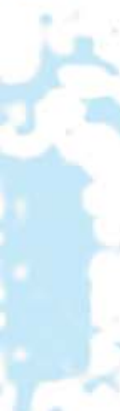

to

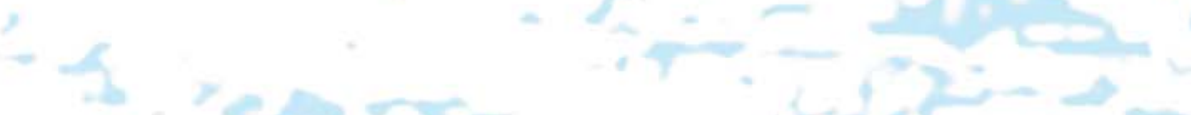
$\therefore \rightarrow-2,3 x-$

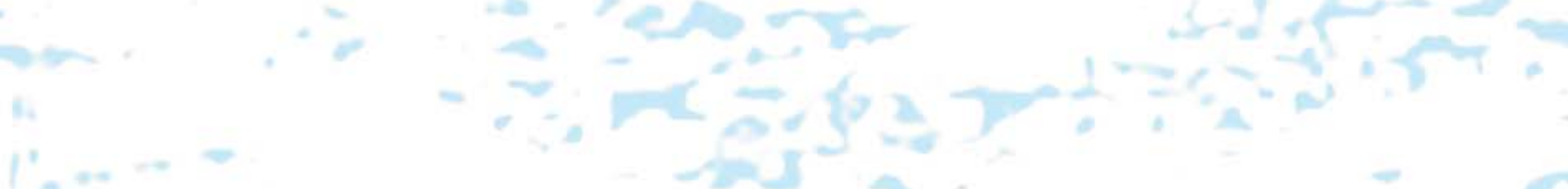

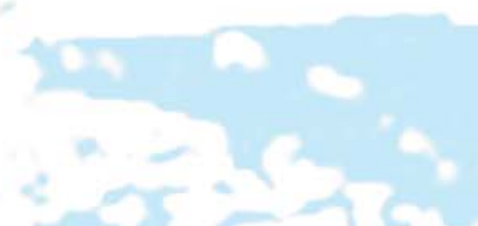

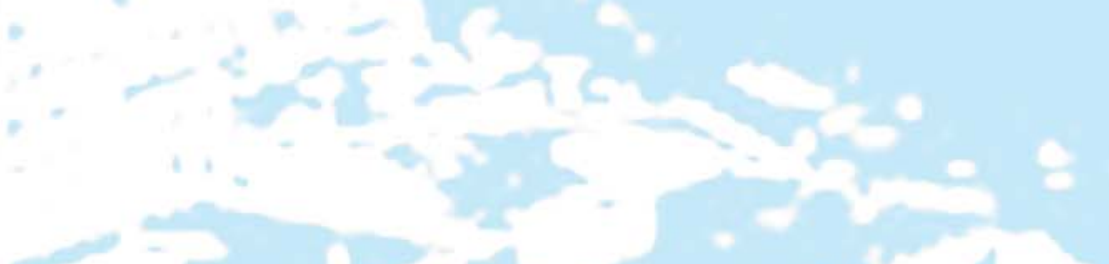

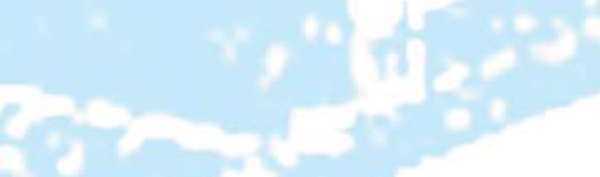

208

है

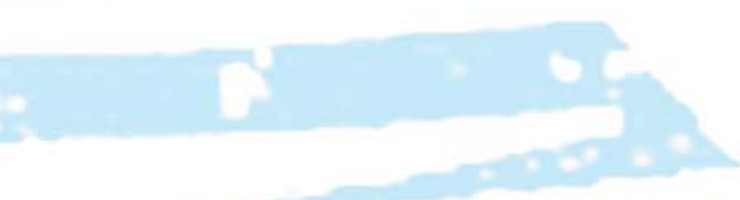

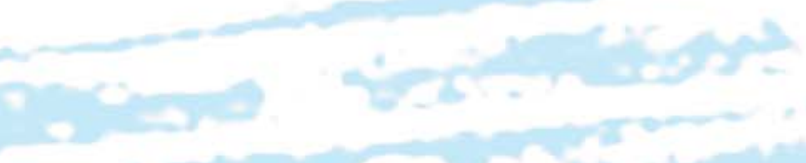

(a) tactit (x) 

PAULA RAQUEL DA ROCHA JORGE VENDRAMINI

\section{A PARTICIPAÇÃO EM CONSELHOS COMO INSTRUMENTO DE GESTÃO MUNICIPAL}

Tese apresentada ao programa de PósGraduação em Saúde Pública para a obtenção do título de Doutor em Ciência.

Área de concentração: Saúde Ambiental

Orientador: Prof. Dr. Arlindo Philippi Jr.

São Paulo

2010 
É expressamente proibida a comercialização deste documento tanto na sua forma impressa como eletrônica. Sua reprodução total ou parcial é permitida exclusivamente para fins acadêmicos e científico, desde que na reprodução figure a identificação do autor, título, instituição e ano da tese. 
Ao Paulo. 



\section{AGRADECIMENTOS}

Em primeiro lugar aos meus pais Celeste Maria dos Santos Rocha Jorge e Manuel Diniz Jorge pelo apoio constante, incondicional e essencial para que este doutorado fosse possível.

Aos meus filhos Vinícius Jorge Vendramini e Caio Jorge Vendramini pela compreensão nos inúmeros dias de trabalho árduo neste trabalho.

Ao Prof. Dr. Arlindo Philippi Jr. que me acolheu inúmeras vezes neste percurso.

À minha amiga e ex-orientadora Profa. Dra. Gilda Collet Bruna pela constante disponibilidade e ajuda essencial.

Ao Prof. Dr. Antonio Carlos Rossin pela grande ajuda na qualificação e na pré-banca e aos professores Ana Lúcia Britto e Klaus Frey pela ajuda na pré-banca.

A todos os meus companheiros de Projeto MEGA Valdir Fernandes, Marcelo Assis, Mariana Rodrigues, Michelle Ramos, Jullyana Abduch e em especial à Juliana Pellegrini Cezare. E aos demais amigos da FSP: Alceu Galvão Jr, Ana Luiza Spínola, Euder Martins, Juliana Zuquer, Maria Luiza Padilha, Sulema Pioli, Sonia Coutinho, e em especial à Glória Barini.

Ao grupo SIADES pelas discussões que contribuíram para o desenvolvimento deste trabalho.

À três amigas imprescindíveis! Juliana Marques, Marcia Lucas e Angélica Alvim.

Às funcionárias da Secretaria de Pós-Graduação da Faculdade de Saúde Pública da Universidade de São Paulo que vão muito além de cumprir suas funções de funcionárias públicas: Angela Maria de Andrade, Maria Aparecida Mendes, Renilda Maria de Figueiredo Shimono, a agora colega 
Samantha Lemos Turte e Vânia Santos. E aos funcionários da biblioteca: Maria Lúcia Ferraz, José Estorniolo Filho e Maria do Carmo Alvarez.

Aos professores da Universidade McGill, em Montreal no Canadá. Ao Prof. Dr. Raphaël Fischler por me abrir as portas, ao Prof. Dr. David Brown por me receber como aluna, à Profa. Dra. Lisa Bornstein pela ajuda direta em vários momentos e à Profa. Dra. Jeanne Wolfe (in memorian) por me acolher em sua sala. Também à Gladys Chan e à Anand Sood pelo apoio e amizade.

Aos funcionários da Prefeitura Municipal de Santo André e aos conselheiros que nos concederam entrevistas.

À Ana Maria Vendramini Costa pela revisão deste trabalho.

À CAPES pelo auxílio financeiro. 


\section{RESUMO}

Este trabalho parte do desenvolvimento urbano sustentável e das políticas públicas como forma de promovê-lo. Os conselhos gestores de políticas públicas estão presentes em todos os níveis de governo, especialmente após a Constituição Federal de 1988. Tomou-se então para análise o município de Santo André pertencente à Região Metropolitana de São Paulo e quatro de seus 23 conselhos municipais relacionados à: Política Urbana, Política Ambiental, Orçamento Participativo e Gestão da Área de Mananciais. Para alcançar o objetivo de analisar o funcionamento dos conselhos municipais de Santo André, buscando reconhecer os pontos em que são exemplares e as ineficiências, foi realizada pesquisa de campo e entrevistas com gestores municipais e conselheiros. As principais conclusões são que Santo André é um caso exemplar em gestão compartilhada, com diversas experiências positivas que, indo muito além das exigências legais de abertura de canais de participação, reiteram a disposição do governo municipal em abrir para a sociedade civil canais de diálogo e deliberação. Porém, não existe uniformidade na atuação dos conselhos e ainda existem problemas, principalmente relacionados com a paridade numérica e a disparidade de condições para que haja um real compartilhamento de poder nos conselhos.

Palavras-chave: desenvolvimento urbano sustentável; conselhos; Santo André. 



\section{ABSTRACT}

This work parts from sustainable urban development and the public policies as a way to promote it. The public policies management councils are present in all levels of the government, especially after the 1988 Federal Constitution. It was taken for analysis the city of Santo André, which belongs to the metropolitan region of São Paulo, and four of its 23 municipal councils related to: Urban Policy, Environmental Policy, Participatory Budget and Management of the Source Water Area. To achieve the objective of analyzing the municipal councils of Santo André, trying to recognize the places in which it is exemplary and its inefficiencies, we carried out field research and interviews with municipal managers and council members. The main conclusions are that Santo André is an exemplary case of shared management, with various positive experiences that, going far beyond the legal requirements for openings channels of participation, reaffirm the willingness of the municipal government to open channels for civil society dialogue and deliberation. However, there is no uniformity in the actions of the councils and there still are problems, mainly related to the numeric parity and the disparity of conditions so that there is a real sharing of power in the councils. However, there is no uniformity in the performance of councils and there are still problems, mainly related to numeric parity and disparity of conditions so that there is a real sharing of power in the councils.

Key-words: $\quad$ sustainable urban development; councils; Santo André. 

1 INTRODUÇÃO _ 23

1.1 OBJETIVO GERAL

1.2 OBJETIVOS ESPECÍFICOS — 29

1.3 ESTRUTURA DA TESE _

2 METODOLOGIA_ 31

2.1 A PESQUISA _ 31

2.2 O PROJETO MEGA E SUA RELAÇÃO COM ESTE TRABALHO __ 32

2.3 DESENVOLVIMENTO DA PESQUISA PARA A TESE __ 35

2.3.1 Pesquisa Documental e Pesquisa Bibliográfica Exploratória___ 35

2.3.2 Entrevistas com Gestores, Observação e Visitas Técnicas___ 36

2.3.3 Estágio de Doutorado no Exterior___ 36

2.3.4 Análise Bibliográfica _ 37

2.3.5 Entrevistas com Conselheiros Municipais _ 37

2.3.6 Tratamento dos Dados _ 42

3 CONSELHOS MUNICIPAIS E GESTÃO LOCAL__ 45

3.1 DESENVOLVIMENTO SUSTENTÁVEL_— 45

3.2 O DESENVOLVIMENTO SUSTENTÁVEL E AS CIDADES _—

3.3 O NOVO CONTEXTO MUNDIAL__ 56

3.4 GOVERNANÇA _ 59

3.5 POLÍTICAS PÚBLICAS _ 67

3.6 PARTICIPAÇÃO_—

3.7 GESTÃO LOCAL —

3.8 CONSELHOS

3.9 ORÇAMENTO PARTICIPATIVO DO PLATEAU-MONT-ROYAL _

3.10 CONSIDERAÇÕES DO CAPÍTULO _ 99

40 MUNICÍPIO DE SANTO ANDRÉ: RESULTADOS DA PESQUISA__ 105

4.1 O MUNICÍPIO DE SANTO ANDRÉ _— 107

4.1.1 A Área Urbana de Santo André___ 111

4.1.2 A Área da Subprefeitura de Paranapiacaba e Parque Andreense ___ 121

4.1.3 Gestão Participativa __ 126

4.2 ENTREVISTAS COM OS GESTORES DE POLÍTICAS PÚBLICAS ___ 139

4.2.1 Secretaria de Desenvolvimento Urbano e Habitação _ـ 142

4.2.2 SEMASA _ 145

4.2.3 Secretaria de Orçamento e Planejamento Participativo ___ 148

4.2.4 Subprefeitura de Paranapiacaba e Parque Andreense 1152

4.3 A REGULAMENTAÇÃO DOS CONSELHOS __ 155

4.3.1 CMPU _ 158

4.3.2 COMUGESAN _ 160

4.3.3 CMO 162

4.3.4 CRPPA 163

4.4 ANÁLISE DAS ENTREVISTAS COM OS CONSELHEIROS ___ 165

4.4.1 Questão 01 • O Papel do Conselho na Prática ___ 167

4.4.2 Questão 02 • As Atividades como Conselheiro ___ 183

4.4.3 Questão 09 - As Principais Vantagens Decorrentes da Existência do Conselho __ 195

4.4.4 Questão 10 - As Principais Dificuldades para o Funcionamento do Conselho __ 209 
4.4.5 Questão 15 - Diferenças de Atuação entre os Conselheiros que são Funcionários e Gestores Públicos e os da Sociedade Civil

4.4.6 Questão 11 a Questão 14 • Questões Relacionadas à Informação para a Participação nos Conselhos

4.4.7 Questão 11 - Você acha que os Conselheiros são Suficientemente Informados para Participar do Conselho?

4.4.8 Questão 12 - Como você se mantém Informado para Participar do Conselho?

4.4.9 Questão 13 - Que tipo de Informação você acha que os Conselheiros deveriam receber para Melhorar a Qualidade de sua Participação no Conselho?

4.4.10 Questão 14 • De que forma estas Informações poderiam chegar até os Conselheiros?

4.5 CONSIDERAÇÕES FINAIS DO CAPÍTULO __ 276

5 DISCUSSÃO DO FUNCIONAMENTO DOS CONSELHOS MUNICIPAIS DE SANTO ANDRÉ 6 CONCLUSÕES

ANEXO A - TERMO DE CONSENTIMENTO ESCLARECIDO

ANEXO B - QUESTIONÁRIO PARA ENTREVISTA COM OS GESTORES DE POLÍTICAS PÚBLICAS DE SANTO ANDRÉ

ANEXO C - QUESTIONÁRIO PARA ENTREVISTAS COM OS CONSELHEIROS

MUNICIPAIS 


\section{LISTA DE TABELAS}

Tabela 1: consolidação do número de conselheiros entrevistados. 41

Tabela 2: papel do conselho - contextos 176

Tabela 3: atividades no conselho - contextos 189

Tabela 4: vantagens da existência do conselho $\cdot$ contextos 203

Tabela 5: dificuldades para o funcionamento do conselho - contextos 220

Tabela 6: diferenças de atuação no conselho - contextos 240

Tabela 7: informações no conselho - contextos 251

Tabela 8: informações no conselho - contextos (continuação) 260

Tabela 9: informações no conselho · contextos (continuação) 266

Tabela 10: informações no conselho · contextos (continuação) 274 



\section{LISTA DE FIGURAS}

Figura 1: etapas do trabalho 32

Figuras 2 e 3: centro antigo de Santo André __ 112

Figuras 4 e 5: bairro Casa Branca___ 113

Figuras 6 e 7: Marginal Guarará ___ 114

Figuras 8 e 9: Vila Pires (esq.) e Jardim Ipanema (dir.) ___ 114

Figuras 10 e 11: Estação de Tratamento de Água (esq.) e Estádio Bruno Daniel (dir.)

Figuras 12 e 13: Clube Aramaçan (esq.) e Parque da Juventude (dir.) ___ 115

Figuras 14 e 15: Parque do Pedroso _ـ 116

Figuras 16 e 17: Centro novo _ 117

Figuras 18 e 19: Shopping ABC (esq.) e Hospital Mario Covas (dir.) ___ 117

Figuras 20 e 21: Parque Central__ 117

Figuras 22 e 23: eixo da Avenida Prestes Maia ___ 118

Figuras 24 e 25: Estação Santo André e SESC _ـ 119

Figuras 26 e 27: presídio (esq.) e Condomínio Prestes Maia (dir.) ___ 119

Figuras 28 e 29: Sacadura Cabral, urbanização realizada pelo Projeto SAMI __ 119

Figuras 30 e 31: Parque das Nações (esq.) e Pólo Petroquímico (dir.) ___ 120

Figuras 32 e 33: conjunto habitacional _ـ 120

Figuras 34 e 35: Parque Andreense, Gleba $2 \ldots 122$

Figuras 36 e 37: Parque Andreense, Gleba $2 \ldots 123$

Figuras 38 e 39: Parque Andreense, Gleba $2 \ldots 123$

Figuras 40 e 41: Parque Andreense, Gleba $3 \_124$

Figuras 42 e 43: Parque Andreense, Gleba $3 \ldots 124$

Figuras 44 e 45: Parque Andreense, Gleba $3 \ldots 124$

Figuras 46 e 47: Chácara Carreras _ـ 125

Figuras 48 e 49:Vila de Paranapiacaba___ 126

Figura 50: relação de representação entre os conselhos estudados ___ 158 



\section{LISTA DE MAPAS}

Mapa 1: localização do Plateau-Mont-Royal e a divisão da subprefeitura em três distritos

Mapa 2: localização - Estado - RMSP - ABC - Santo André 108

Mapa 3: Município de Santo André 109

Mapa 4: principais eixos de Santo André

Mapa 5: SPPA - Parque Andreense e Paranapiacaba 121

Mapa 6: área do Projeto do Eixo Tamanduatehy 129

Mapa 7: regiões do OP de Santo André 162 



\section{LISTA DE GRÁFICOS}

Gráfico 1: Papel do Conselho - contexto A _ 177

Gráfico 2: Papel do Conselho - contexto B _ 177

Gráfico 3: Papel do Conselho - contexto A+B _ـ 178

Gráfico 4: Papel do Conselho - contexto $C \_178$

Gráfico 5: Papel do Conselho - contexto D_ 179

Gráfico 6: Papel do Conselho - contexto C+D _ 179

Gráfico 7: Papel do Conselho - contexto E 180

Gráfico 8: Papel do Conselho - contexto F_ 180

Gráfico 9: Papel do Conselho - contexto G_ 181

Gráfico 10: Papel do Conselho - contexto H__ 181

Gráfico 11: Atividades - Contexto A _ 190

Gráfico 12: Atividades - Contexto B 190

Gráfico 13: Atividades - Contexto C 191

Gráfico 14: Atividades - Contexto D _ 191

Gráfico 15: Atividades - Contexto E_ 192

Gráfico 16: Atividades - Contexto F__ 192

Gráfico 17: Atividades - Contexto G 193

Gráfico 18: Atividades - Contexto H 193

Gráfico 19: Atividades - Contexto I____ 194

Gráfico 20: Vantagens - Contexto A _ 204

Gráfico 21: Vantagens - Contexto B _ 204

Gráfico 22: Vantagens - Contexto C— 205

Gráfico 23: Vantagens - Contexto D 206

Gráfico 24: Vantagens - Contexto E _ 206

Gráfico 25: Vantagens - Contexto F__ 207

Gráfico 26: Vantagens - Contexto G_ 207

Gráfico 27: Dificuldades - Contexto A__ 221

Gráfico 28: Dificuldades - Contexto B _ـ 221

Gráfico 29: Dificuldades - Contexto C__ 222

Gráfico 30: Dificuldades - Contexto D__ 223

Gráfico 31: Dificuldades - Contexto E__ 223

Gráfico 32: Dificuldades - Contexto F_ 224

Gráfico 33: Dificuldades - Contexto G__ 225

Gráfico 34: Dificuldades - Contexto H__ 225

Gráfico 35: Atuação - Contexto A _ 241

Gráfico 36: Atuação - Contexto B _ 241

Gráfico 37: Atuação - Contexto C 242

Gráfico 38: Atuação - Contexto D _ 243

Gráfico 39: Informações - Contexto A__ 251

Gráfico 40: Informações - Contexto B__ 252 
Gráfico 41: Informações - Contexto C 252

Gráfico 42: Informações - Contexto D

Gráfico 43: Informações - Contexto E

Gráfico 44: Informações - Contexto F

Gráfico 45: Informações - Contexto $G$

Gráfico 46: Informações - Contexto H

Gráfico 47: Informações - Contexto I

Gráfico 48: Informações - Contexto J

Gráfico 49: Informações - Contexto K

Gráfico 50: Informações - Contexto L

Gráfico 51: Informações - Contexto M

Gráfico 52: Informações - Contexto N 


\section{LISTA DE SIGLAS}

AMA-Paranapiacaba Associação dos Monitores Ambientais de Paranapiacaba

CETESB

CIDA

COMUGESAN

CMO

CMPU

CONAMA

CONDEPHAAT

CRPPA

EESC

ETA

ETE

FAPESP

FSP

FUMGESAN

GEPAM

LOM

NEPA

OCDE

ONG

ONU

OP

PIIS
Companhia Ambiental do Estado de São Paulo

Agência Canadense para o Desenvolvimento Internacional

Conselho Municipal de Gestão e Saneamento Municipal de Santo André

Conselho Municipal de Orçamento

Conselho Municipal de Política Urbana

Conselho Nacional de Meio Ambiente

Conselho de Defesa do Patrimônio Histórico, Artístico e Turístico do Estado de São Paulo

Conselho de Representantes de Paranapiacaba e Parque Andreense

Escola de Engenharia de São Carlos

Estação e Tratamento de Água

Estação e Tratamento de Esgoto

Fundação de Amparo à Pesquisa do Estado de São

Paulo

Faculdade de Saúde Pública

Fundo Municipal de Gestão e Saneamento Ambiental

Gerenciamento Participativo de Áreas de Mananciais

Lei Orgânica Municipal

"National Environmental Policy Act"

Organização de Cooperação para o Desenvolvimento

Econômico

Organização não Governamental

Organização das Nações Unidas

Orçamento Participativo

Projeto Integrado de Inclusão Social 


\begin{tabular}{|c|c|}
\hline PMSA & Prefeitura Municipal de Santo André \\
\hline PNUMA & Programa das Nações Unidas para o Meio Ambiente \\
\hline PT & Partido dos trabalhadores \\
\hline Projeto MEGA & $\begin{array}{l}\text { Avaliação Estratégica do Processo de Implementação } \\
\text { das Políticas de Desenvolvimento e Meio Ambiente no } \\
\text { Município de Santo André - SP }\end{array}$ \\
\hline RMSP & Região Metropolitana de São Paulo \\
\hline SABESP & $\begin{array}{l}\text { Companhia de Saneamento Básico do Estado de São } \\
\text { Paulo }\end{array}$ \\
\hline SAMI & Santo André Mais Igual \\
\hline SEMASA & $\begin{array}{l}\text { Serviço Municipal de Saneamento Ambiental de Santo } \\
\text { André }\end{array}$ \\
\hline SIADES & $\begin{array}{l}\text { Sistema de Informações Ambientais para o } \\
\text { Desenvolvimento Sustentável }\end{array}$ \\
\hline SISNAMA & Sistema Nacional de Meio Ambiente \\
\hline SOPP & Secretaria de Orçamento e Planejamento Participativo \\
\hline SDUH & Secretaria de Desenvolvimento Urbano e Habitação \\
\hline SPPA & Subprefeitura de Paranapiacaba e Parque Andreense \\
\hline
\end{tabular}



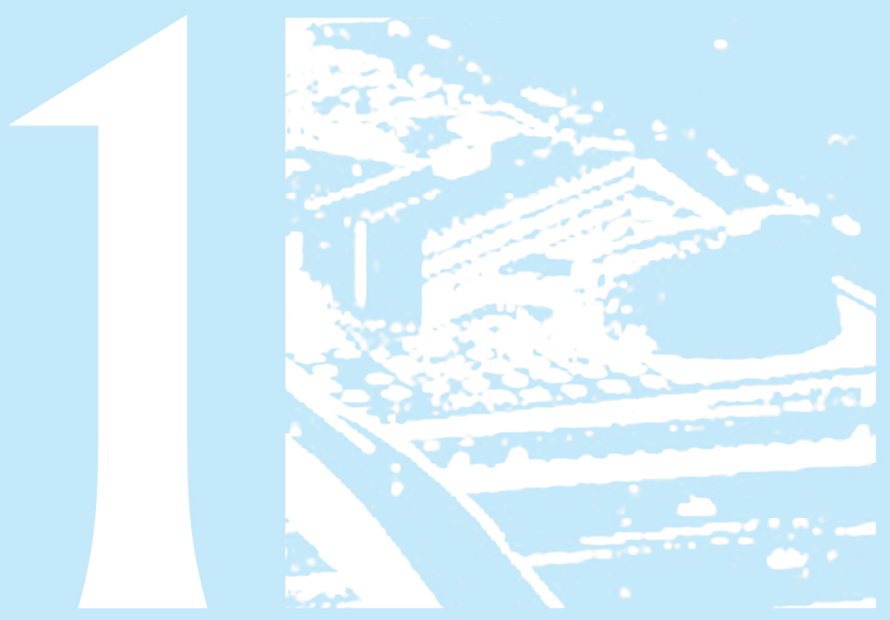

I N TRODUCAO 



\section{INTRODUÇÃO}

Os remanescentes de ambiente natural nas cidades ${ }^{1}$ são reduzidos, e, na maioria dos municípios encontram-se fragmentados e dispersos. Algumas cidades instituíram um sistema de áreas verdes formados por parques e recursos hídricos. Porém, mesmo sendo bastante reduzido, esse ambiente natural presta serviços insubstituíveis aos cidadãos. $O$ banco genético de fauna e flora ou a absorção dos resíduos gerados pelas atividades humanas dependem de área natural. É também no campo que são produzidos alimentos, energia e materiais importados pelas cidades, e trabalhados em seus laboratórios.

Com essas características, os problemas ambientais devem ser compreendidos como parte de um cenário maior, a sustentabilidade. Em prol desta, busca-se reduzir os impactos cooperando com a preservação dos recursos naturais em escala planetária. Satterthwaide (2005) revela que as previsões da Organização das Nações Unidas (ONU) quanto à urbanização para o ano 2000 não foram alcançadas. Estavam previstas formação de 27 mega-cidades $^{2}$ e, na realidade, na virada do século, só existiam 18. Além disso, em 2004 constatou-se que, a previsão de população urbana ainda não era superior à rural no ano 2000, estimando-se que haveria inversão desta afirmação somente em 2007.

Mesmo com esta situação a sustentabilidade urbana continua sendo assunto urgente: afinal, não são apenas as grandes cidades que precisam conciliar o desenvolvimento sócio-econômico com o ambiental. Além disso, há ainda pesquisadores que consideram difícil separar ambientes

\footnotetext{
${ }^{1}$ As cidades são entendidas como sede do município.

2 A divisão das Nações Unidas da ONU previu em 1973-75 que existiriam 27 Mega-cidades até o ano 2000 e em 1984-85, estimou em 23 (United Nations, 1975; United Nations, 1987 apud Sattewaite, 2005).
} 
urbanos de não urbanos (COSTA, 1999), ou, como Acselrad (2009) aponta, há dificuldade de restringir o estudo de sustentabilidade urbana às cidades.

Tanto a globalização como o desenvolvimento sustentável afloraram como questões de planejamento na década de 1980. Como conseqüência da globalização, houve perda do poder dos Estados com o aumento de poder de organizações supra-nacionais e de grandes empresas multinacionais. Estas mudanças significaram a transferência de atividades típicas do setor público para o setor privado, como no caso das empresas privatizadas, fragmentando o sistema político.

Neste contexto, o papel do governo local tem sido ampliado no mundo todo. No Brasil, a partir da Constituição Federal de 1988 os municípios receberam mais autonomia, e, em conseqüência, mais atribuições administrativas. Nesta nova realidade são necessárias políticas municipais para dar conta das novas atribuições, inclusive o desenvolvimento urbano sustentável. Além disso, as prefeituras - principalmente dos pequenos municípios brasileiros - não contam com recursos humanos capacitados e com os recursos financeiros necessários para esta administração.

Na década de 1980, três fatores trouxeram para a discussão a questão da descentralização com aumento do poder municipal: o primeiro, diz respeito ao enfraquecimento dos governos nacionais decorrente da globalização; o segundo, a associação da democratização à descentralização (PINHO; SANTANA, 1988); e o terceiro trata da emergência das questões ambientais que têm na escala local a sua expressão mais nítida (DOWBOR, 2003).

Assim, a década de 1980 foi marcada além do já mencionado decrescente poder do Estado, decorrente da globalização, pela crescente participação da sociedade civil organizada nas decisões públicas, principalmente nas cidades. A constituição de 1988 ampliou os canais de democracia representativa, que, segundo Gohn (2007a) decorre da 
associação entre elementos da democracia direta com a democracia representativa, por meio, por exemplo, de conselhos, que proliferaram no Brasil na década de 1990.

Este período foi marcado por dois fatores: o crescente envolvimento de atores sociais na gestão de políticas; e o questionamento tanto do padrão autoritário e excludente existente na política nacional quanto da capacidade de atender às demandas sociais (TATAGIBA, 2000).

Nessa nova conformação a administração inclui a participação da população que, de um lado pode pressionar o poder público em prol das mudanças, enquanto de outro, precisa ser conscientizada e capacitada. Assim como os cidadãos, precisam de capacitação, os municípios precisam dominar instrumentos de gestão pública que organizem e facilitem o enfrentamento da complexidade do desenvolvimento sustentável. Decorre daí a necessidade de melhorar o processo de formulação e avaliação de políticas públicas, aprimorando assim a governança local: tanto na forma da gestão, quanto nos resultados obtidos.

Percebe-se então que é através da participação da população que se tem a oportunidade de quebrar o ciclo do clientelismo ${ }^{3}$, transferindo uma situação de dependência para uma situação de responsabilidade compartilhada onde haja a busca de construção de objetivos conjuntos. Por isto, para Guerra (2006) existem três desafios a serem enfrentados: a gestão da complexidade; a necessidade de eficácia e a legitimidade das decisões.

Segundo estes objetivos, diversos mecanismos estão sendo criados, em diversos países, inclusive no Brasil. Nesta forma de gestão, inclui-se a governança participativa também conhecida como democracia deliberativa, pois é um instrumento democrático deliberativo e empoderante (GAVENTA, 2001). Para Bresser-Pereira (2007, p.6), "é um modelo de 3 "[...] método de resolução de negócios públicos por meio de procedimentos diretos,
privilegiando interesses particulares (GOHN, 2007, p.53). 
governança porque envolve outros atores, além do próprio governo, no processo de governar". No entanto, existem diversas formas de participação popular na gestão pública. Algumas são trabalhadas na literatura internacional, como o referendo, o plebiscito ou a iniciativa popular. No Brasil, a criação dos conselhos, por sua vez, responde à demanda dos cidadãos por espaço na administração e não tem base em estudos acadêmicos de outros países (CALDERÓN; MARIN, 2002).

Foi nos municípios que os conselhos se proliferaram, até porque, sua existência em alguns casos, é condição para o repasse de verbas. Bava (2005) estimou que no Brasil existem 27 mil conselhos paritários e deliberativos, a maioria nos municípios ${ }^{4}$. Esses conselhos gestores se tornam formas de ampliação da esfera pública, uma vez que fortalecem os canais existentes para a formação de opinião e a tomada de decisão, contribuindo, assim, para a inserção de novos temas na agenda política (DANIEL, 2000).

Segundo Guerra (2006) deve-se ter cuidado para não valorizar a forma participativa em detrimento do conteúdo gerado por este processo participativo. Assim sendo, é importante entender quem participa, como se dá essa participação, quais os consensos e conflitos gerados e, principalmente, se existe direcionamento na tomada de decisão. É que o conceito de poder local é mais abrangente que o do governo local, pois inclui as novas formas de participação popular. Não é a sede do governo, mas o espaço de gestão político administrativa. Assim, segundo Gohn (2007a), a governança local tem como objetivo articular o poder local com o governo local, o segundo inserido no primeiro. Reiterando esta colocação, a Agenda 21 , documento criado na Rio $92^{5}$ chama a atenção para a necessidade de desenvolver estratégias participativas para a promoção do desenvolvimento

\footnotetext{
${ }^{4}$ Existem outras estimativas bastante díspares, como a de TONELA (2006) que estimou em 15 mil o número de conselhos municipais.

${ }^{5}$ Convenção internacional que aconteceu na cidade do Rio de Janeiro no ano de 1992, chamada de "Cúpula da Terra", "Rio 92" ou "Eco-92",
} 
sustentável. Este documento indica a necessidade de se estabelecer parcerias entre os setores público e privado, sem apontar quais seriam os mecanismos para que isto aconteça. Os conselhos podem ser a opção.

Atualmente, no Brasil, os conselhos são os responsáveis pela gestão das políticas públicas em diversos municípios. Eles têm a prerrogativa de serem canais de gestão compartilhada, de forma paritária entre representantes do poder público e da sociedade civil organizada, para a solução dos problemas públicos. São instituições que visam fortalecer a democracia, apresentando elementos da democracia direta, uma vez que inclui membros da sociedade civil, deliberando assuntos públicos e, elementos da democracia representativa, já que estes são representantes eleitos por seus pares (LÜCHMANN, 2007; ANASTÁCIA; AZEVEDO, 2002). Estes são também reconhecidos como instituições híbridas, por serem formados por representantes do governo e da sociedade civil. Esses conselhos têm sido o expoente da democracia deliberativa no Brasil, principalmente nos municípios (MONTEIRO; FLEURY, 2006).

Camargo (2003) afirma que, mesmo com duas décadas de história, o problema é que muitas vezes os conselhos não conseguem exercer a influência desejada na gestão pública. Segundo esta autora, isto questiona a capacidade deliberativa de fato desses conselhos, pois podem ser suscetíveis à manipulação política. Neste caso, estes mecanismos perderiam a capacidade de contribuir com o processo de construção da sustentabilidade urbana, uma vez que a sociedade civil não estaria contribuindo de fato no processo decisório.

Segundo Frey (2000, p.251) os estudos de políticas públicas têm dado enfoque principalmente em casos empíricos, apresentando validade apenas situacional. Sente-se a ausência de estudos na dimensão processual. Por isto o objetivo desta tese é focalizar os processos de gestão de políticas, através dos conselhos municipais. 
Assim, este trabalho toma como caso de estudo o município de Santo André, na Região Metropolitana de São Paulo (RMSP). Dois fatores principais levaram a esta escolha. O primeiro diz respeito à situação geográfica do município. Santo André pertence à região do Grande $A B C$, na RMSP, formada pelos municípios de Santo André, São Bernardo do Campo e São Caetano do Sul, que, com suas iniciais dão nome à região, e inclui ainda Diadema, Mauá, Ribeirão Pires e Rio Grande da Serra e tem sua mancha urbana conurbada com os municípios vizinhos. Ao mesmo tempo, parte se seu território é pouco ocupada e está em Área de Proteção e Recuperação dos Mananciais. O segundo está no pioneirismo de Santo André na adoção de mecanismos participativos na gestão municipal deste 1989 com o orçamento participativo, mas com maior ênfase na década de 1990, com diversos projetos e conselhos municipais, tornando-o um caso para estudo.

Assim, como desenvolvimento sustentável e sua aplicação nas cidades, através da sustentabilidade urbana, tem sido a meta da maioria dos municípios nesta mudança de século, as políticas públicas são a forma de materializar estas ambições. Tomando-se Santo André como caso de estudo, dentre os 23 conselhos municipais, destacam-se quatro como principais agentes da sustentabilidade urbana, a saber: o CMPU, por ser 0 gestor da política urbana; o COMUGESAN, por administrar a política ambiental; o CMO, por ser o maior canal receptor de demandas da população naquele município; e o CRPPA, por ser o conselho de representantes dos habitantes de metade da área municipal que está totalmente inserida em área de proteção e recuperação de mananciais. Cada um deles é individualmente importante para a gestão ambiental urbana, mas não se pode desprezar a necessidade de uma interação sólida entre si. A sustentabilidade urbana de Santo André depende, em grande parte, de cada uma destas instituições e das relações entre elas. 


\subsection{OBJETIVO GERAL}

- Analisar o funcionamento de conselhos municipais de Santo André, visando identificar progressos e fragilidades para propor ajustes e melhorias.

\subsection{OBJETIVOS ESPECÍFICOS}

- Construir referencial teórico que dê suporte à análise e interpretação dos dados levantados em campo;

- Caracterizar o município de Santo André, tanto do ponto de vista do território e sua ocupação, quanto dos processos de gestão participativa que vêm ocorrendo;

- Descrever e discutir o processo de gestão de políticas públicas em Santo André, a partir de entrevistas com os gestores; e

- Analisar e discutir o funcionamento dos conselhos, por meio de entrevistas cedidas pelos conselheiros.

\subsection{ESTRUTURA DA TESE}

Esta tese está organizada em seis capítulos. Este primeiro consta da introdução e dos objetivos do trabalho e o segundo capítulo apresenta a metodologia utilizada. 
O terceiro capítulo é fruto de revisão da bibliografia para se construir o referencial teórico sobre desenvolvimento sustentável e conselhos municipais; incluindo outros temas que apóiam esta tese, como: governança, políticas públicas e participação social na gestão pública. Neste se estabelece uma ligação entre a problemática do desenvolvimento sustentável e o papel das áreas urbanas. Também conduz o leitor a compreender as novas formas de gestão urbana, principalmente após a Constituição Federal de 1988 e os novos espaços de reivindicação e deliberação sobre políticas públicas: os conselhos.

O capítulo 4 concentra a sistematização de dados levantados em campo. Inicia apresentando Santo André, com suas especificidades urbanas e de gestão democrática. Relata as entrevistas com os gestores municipais mostrando os mecanismos de formulação e implementação das políticas públicas. Passa então o foco para os conselhos, examinando-se a legislação municipal e o regimento destes colegiados para, na seqüência, analisar as entrevistas realizadas com os conselheiros.

No quinto capítulo, discutem-se os resultados encontrados, buscando identificar os avanços dos conselhos e os aspectos que ainda são um entrave para a plena participação social. Também busca compreender se, mesmo em municípios que incorporam e estimulam a democracia deliberativa desde a década de 1990 - logo após a promulgação da Constituição Federal de 1988 -, o processo de tomada de decisão nos conselhos municipais pode apresentar fragilidades.

No sexto e último capítulo são apresentadas as conclusões da tese. 

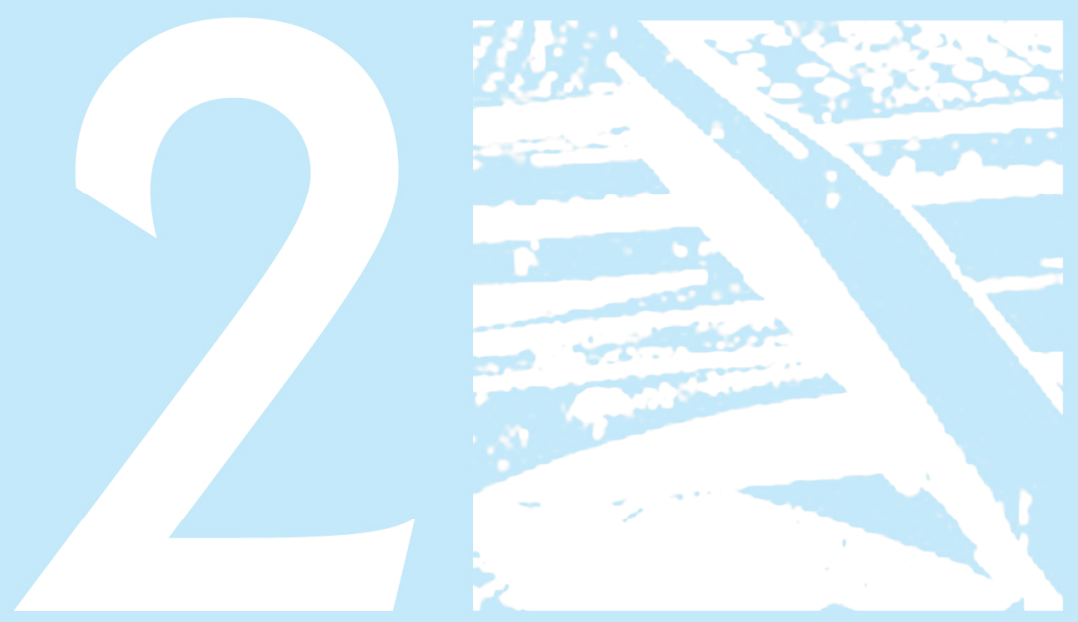

METO D OLOGIA 



\section{METODOLOGIA}

\subsection{A PESQUISA}

Os conselhos municipais ${ }^{6}$ são instrumentos institucionalizados de participação da sociedade civil organizada na gestão municipal. Esta pesquisa parte do particular e da observação destes conselhos e utiliza um raciocínio indutivo podendo generalizar dados particulares. Esta forma de pesquisa teve início com Francis Bacon (15611626) e tornou-se muito utilizada principalmente entre as ciências sociais (GIL, 1999).

A figura 1 mostra as fases da pesquisa. Para seu delineamento empreendeu-se uma etapa exploratória, com o objetivo de conhecer o problema e estabelecer as hipóteses. Esta fase envolveu pesquisa bibliográfica e documental, entrevistas com gestores municipais, observação dos conselhos, visitas de campo a Santo André e o estágio de doutorado no exterior ${ }^{7}$.

Para estabelecer as fases seguintes da pesquisa - fase descritiva e fase explicativa - foram estruturadas entrevistas, inseridas no contexto do Projeto MEGA ${ }^{8}$. Destas resultou material de análise que corroborou a definição da hipótese de pesquisa: o processo de tomada de decisão nos conselhos municipais, apesar de apresentar progressos importantes, apresenta fragilidades, mesmo em municípios que incorporam e

${ }^{6}$ Previstos na Constituição Federal de 1988 e na Lei Orgânica Municipal de Santo André de 1990.

7 Suporte aos estudos desta tese realizado em Estágio de doutorado no Exterior na Universidade McGill em Montreal, Canadá, durante o primeiro semestre de 2008, com apoio financeiro da CAPES.

8 "Avaliação Estratégica do Processo de Implementação das Políticas de Desenvolvimento e Meio Ambiente no Município de Santo André - SP", com participação da autora. 
estimulam a democracia deliberativa a partir da Constituição Federal de 1988.

Nesta pesquisa parte-se da análise de conselhos municipais instituídos e em operação, tomando para estudo o município de Santo André. Procura-se compreender como as decisões dos conselhos vêm sendo tomadas e, se existem fragilidades neste processo.
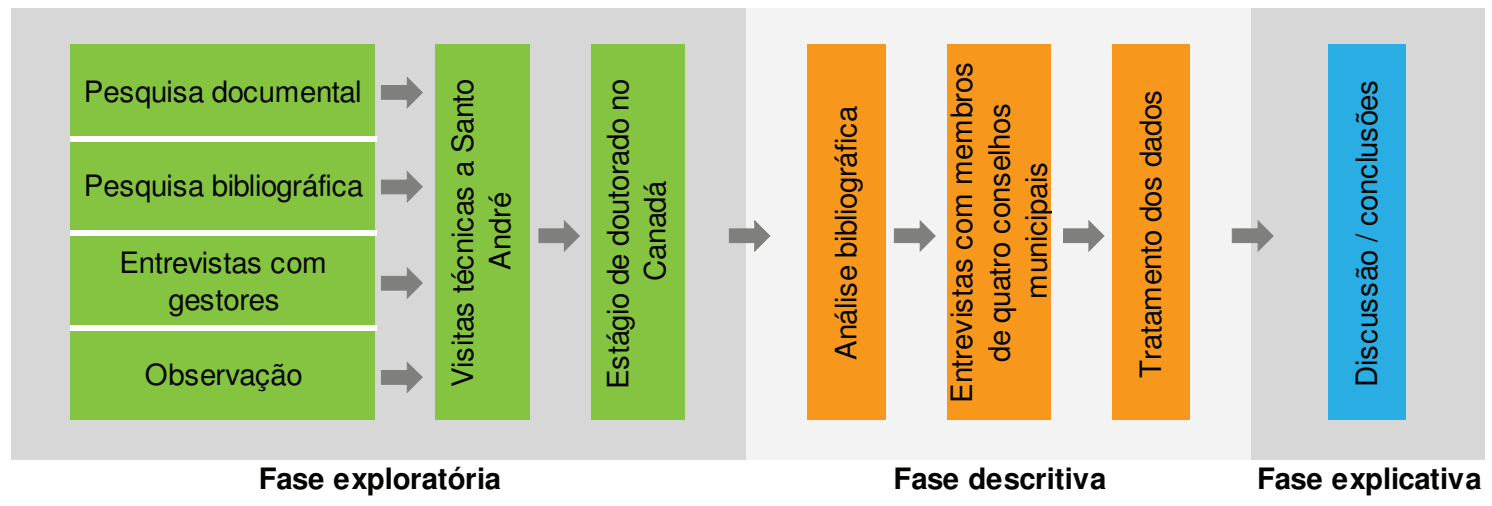

Figura 1: etapas do trabalho

Fonte: organizada para esta tese pela autora. Vendramini, 2010.

\subsection{O PROJETO MEGA E SUA RELAÇÃO COM ESTE TRABALHO}

Este trabalho é parte do projeto MEGA (Avaliação Estratégica do Processo de Implementação das Políticas de Desenvolvimento e Meio Ambiente no Município de Santo André - SP), com apoio financeiro da FAPESP, dentro do programa "Políticas Públicas 7" entre 2007 e 2009.

O MEGA teve como objetivo desenvolver uma análise estratégica de processo de gestão ambiental, no contexto da promoção da qualidade de vida e do desenvolvimento sustentável. O projeto foi desenvolvido por equipe de professores, alunos e pesquisadores da Faculdade de Saúde Pública e da Escola de Engenharia de São Carlos, ambas da Universidade de São Paulo, assim como com o apoio de professores de 
outras instituições nacionais e internacionais em diversas oficinas, e foi dividido em duas etapas, de acordo com especificação da própria FAPESP. A primeira etapa, de seis meses - primeiro semestre de 2007 -, foi preparação para a segunda etapa de dois anos - desenvolvida em 2008 e 2009.

Para o desenvolvimento do Projeto MEGA, onde se insere o projeto de pesquisa da autora, anteriormente mencionado, foram realizadas pesquisas de campo. A primeira fase do trabalho, de caráter exploratório, desenvolveu-se extenso levantamento e análise documental; foram também realizadas entrevistas com gestores locais de diversas secretarias e órgãos municipais que tinham ligações de trabalho com os processos relacionados às políticas públicas de Santo André: Subprefeitura de Paranapiacaba e Parque Andreense; Secretaria Municipal de Saúde; Secretaria de Planejamento e Orçamento Participativo; Secretaria de Desenvolvimento Econômico; Secretaria de Educação; Secretaria de Desenvolvimento Urbano; Secretaria de Administração e Modernização; Serviço Municipal de Saneamento Ambiental de Santo André (SEMASA); Departamento de Parques e Áreas Verdes e Ouvidoria. Ainda nesta etapa foram realizadas duas visitas técnicas que trouxeram à equipe um conhecimento mais profundo do município. A primeira foi acompanhada por uma gerente da Subprefeitura que apresentou à equipe as diversas tipologias de ocupação da região, que é Área de Proteção e Recuperação dos Mananciais. A segunda visita foi viabilizada pelo SEMASA, e acompanhada por um arquiteto da Secretaria de Planejamento e Orçamento Participativo que apresentou à equipe a área urbana do município, com seus diversos padrões de ocupação e os principais projetos urbanos em andamento.

$\mathrm{Na}$ segunda fase do projeto, foram realizados diversos levantamento de dados:

Foi desenvolvida pesquisa junto à população da área da Subprefeitura de Paranapiacaba e Parque Andreense (SPPA) através de 
questionário quantitativo que levantou a percepção desta população com relação às políticas ambientais daquela região.

Foi realizada pesquisa junto aos alunos das escolas de ensino fundamental e médio da região da SPPA através de questionários quantitativos e qualitativos que levantou a percepção dos alunos com relação às políticas ambientais da região.

Foi desenvolvida pesquisa qualitativa - por meio de questionários realizados com perguntas abertas para entrevista - sobre a estrutura e o funcionamento dos conselhos municipais com os conselheiros da sociedade civil organizada e do poder público em quatro conselhos municipais: o Conselho Municipal de Política Urbana (CMPU), o Conselho Municipal de Gestão Ambiental e Saneamento de Santo André (COMUGESAN), o Conselho Municipal de Orçamento (CMO) e o Conselho de Representantes de Paranapiacaba e Parque Andreense (CRPPA).

Por fim, foi aplicado questionário qualitativo e quantitativo com os gestores da Subprefeitura de Paranapiacaba e Parque Andreense.

O material para o projeto MEGA e para os trabalhos individuais dos pesquisadores mestrandos e doutorandos envolvidos foi levantado em conjunto pela equipe do projeto, estabelecendo-se coordenadores para cada segmento do trabalho, de acordo com seu enfoque de pesquisa. Além dos questionários e entrevistas, a equipe participou de reuniões de conselho tanto ordinárias quanto reuniões de devolutiva do Projeto MEGA, e reuniões de pesquisa com os gestores municipais. Foram realizadas ainda oficinas de trabalho que contaram com a participação de pesquisadores do Projeto, professores de outras instituições nacionais e internacionais, assim como representantes da PMSA e dos conselhos estudados ${ }^{9}$.

9 A autora contribuiu como membro do grupo de pesquisa para a preparação destas oficinas
e seminários desenvolvidos no Projeto MEGA, e teve a responsabilidade de organizar dois VENDRAMINI, Paula R. Jorge A participação em conselhos como instrumento de gestão municipal 
Para esta tese foram utilizadas quatro entrevistas da fase exploratória do projeto MEGA com gestores das instituições que coordenam os quatro conselhos estudados: Secretaria de Desenvolvimento Urbano, que é responsável pelo CMPU; Serviço Municipal de Saneamento Ambiental de Santo André (SEMASA), responsável pelo COMUGESAN; Secretaria de Planejamento e Orçamento Participativo, responsável pelo CMO; e a Subprefeitura de Paranapiacaba e Parque Andreense, responsável pelo CRPPA. Foram também utilizadas nove das 20 questões que compõem as entrevistas realizadas com os membros destes conselhos, selecionadas em função da pertinência com o tema do trabalho e se respeitando a autoria dos demais trabalhos relacionados ao projeto MEGA, desenvolvidos por outros pesquisadores mestrandos e doutorandos, acompanhados por pósdoutorandos.

\subsection{DESENVOLVIMENTO DA PESQUISA PARA A TESE}

\subsubsection{Pesquisa Documental e Pesquisa Bibliográfica Exploratória}

Foi realizada pesquisa documental no município de Santo André, onde se levantou e analisou textos de lei; mapas indicando equipamentos urbanos; informes de Paranapiacaba, SEMASA e da prefeitura, planos e organogramas setoriais; sumários de dados do município; plano diretor; além de compilação de material digital disponível em sites oficiais da prefeitura e das secretarias de Santo André. discussão de resultados parciais, com participação de professores de outras instituições Nacionais e Internacionais, com o apoio de Videoconferência, realizado na FSP.USP. 
Paralelamente houve o levantamento e análise de material bibliográfico relacionado aos conselhos municipais de Santo André e os processos participativos no município [figura 1 - fase exploratória].

\subsubsection{Entrevistas com Gestores, Observação e Visitas Técnicas}

Realizou-se visitas ao município e reuniões com os gestores municipais, assim como participação em reuniões de conselho ${ }^{10}$. Como forma de confirmar ou refutar impressões obtidas em conversas com atores do governo municipal de Santo André, foi desenvolvida uma série de entrevistas com gestores públicos envolvidos nos processos de formulação e acompanhamento de políticas públicas das diversas áreas do município, gerando um diagnóstico preliminar [anexo B]. Duas visitas técnicas acompanhadas por gestores públicos de Santo André contribuíram para o delineamento do problema, nesta fase exploratória [figura 1 " fase exploratória].

\subsubsection{Estágio de Doutorado no Exterior}

O estágio de doutorado no exterior realizado pela autora ocorreu na Universidade McGill, em Montreal, Canadá, contribuindo para a ampliação do repertório sobre participação social na gestão local. Nesta oportunidade foram acompanhados processos participativos no município de Montreal, com especial interesse para o orçamento participativo do PlateauMont-Royal ${ }^{11}$. Um extenso levantamento bibliográfico também foi realizado

${ }^{10}$ Coordenada e desenvolvida parcialmente pela autora.

${ }^{11}$ O Plateau-Mont-Royal é uma das subprefeituras de Montreal e estava iniciando o seu processo de orçamento participativo no período do estágio, primeiro semestre do 2008. Além dele, foram acompanhados alguns projetos do Centre D'écologie Urbaine de 
naquela oportunidade e os professores da universidade orientaram os trabalhos teóricos e práticos naquele período [figura 1 - fase exploratória].

\subsubsection{Análise Bibliográfica}

Para que fosse estabelecida a base teórica desta tese, foi realizada pesquisa bibliográfica de modo que fossem explicitados os conceitos relacionados aos conselhos municipais e respectivo contexto sóciopolítico. O levantamento e a seleção do material bibliográfico foi realizado junto a duas bibliotecas, utilizando-se tanto os acervos físicos, quanto os banco de dados com trabalhos científicos disponíveis nestas instituições. As bibliotecas utilizadas foram: a biblioteca da Faculdade de Saúde Pública da Universidade de São Paulo e a Biblioteca da Universidade McGill em Montreal, no Canadá [figura 1 - fase exploratória].

\subsubsection{Entrevistas com Conselheiros Municipais}

Nesta parte da fase descritiva do trabalho, foram realizadas entrevistas com conselheiros do poder público e da sociedade civil do município de Santo André ${ }^{12}$ [anexo C]. Foram quatro os conselhos municipais entrevistados. Dentre os 22 conselhos temáticos existente no município, foram selecionados os conselhos de meio ambiente (COMUGESAN), de política urbana (CMPU), do orçamento participativo (CMO) e o da área de manancial (CRPPA). O COMUGESAN foi selecionado por ser o conselho que trabalha diretamente com os assuntos ambientais no município. O CMPU pela forte interface entre as questões urbanas e ambientais, principalmente em

Montreal (CEU), entre eles os indicadores de sustentabilidade do Milton Parc, bairro onde se localiza o CEU.

12 Desenvolvida pelo grupo de pesquisa com participação relevante da autora. 
uma cidade inserida em contexto de região metropolitana como é Santo André. O CMO, conselho que gere o orçamento participativo, por ser 0 conselho que recebe as demandas de intervenção no município vindas de seus cidadãos, com forte influência na ocupação e no desenvolvimento urbano da municipalidade. Por fim, o CRPPA apresenta estreita ligação com a área de mananciais de Santo André, pois o território gerido por esta subprefeitura está totalmente inserido em Área de Proteção e Recuperação dos Mananciais. A partir desta seleção de conselhos foram estruturadas e aplicadas entrevistas aos conselheiros, tanto do poder público, quanto da sociedade civil organizada [figura 1 - fase explicativa].

O roteiro desta entrevista foi montado de acordo com os princípios colocados por Minayo (2008) onde cada questão permite ampliar e aprofundar a comunicação, contribuindo para que as visões, os fatos, e as relações formadas pelo entrevistado apareçam. Cada questão contribui para que se forme um cenário do conteúdo pesquisado: o funcionamento dos conselhos municipais. As entrevistas são um instrumento de pesquisa qualitativa.

A formulação de cada questão foi realizada em uma oficina de trabalho interna com os membros do projeto MEGA, de forma a estabelecer os objetivos das perguntas, tanto àquelas para fornecer material de análise diretamente para o projeto, quanto às que foram utilizadas indiretamente pelos mestrados e doutorados dos pesquisadores da equipe MEGA. A partir dos objetivos definidos, as questões foram formuladas, e para sua aplicação os pesquisadores foram treinados para ir a campo. Houve cuidado para que não houvesse indução das respostas, bem como houve ajuste do vocabulário, de forma a evitar problemas de compreensão entre pesquisadores e respondentes, dado que o público a ser entrevistado tinha nível de escolaridade muito heterogêneo. Assim sendo, nesta oficina de 
trabalho utilizou-se as técnicas ensinadas na disciplina "Discurso do Sujeito Coletivo"13.

A entrevista desenvolvida foi composta de três partes ${ }^{14}$. Das 20 questões que compõem a segunda parte da entrevista, apenas nove foram utilizadas nesta tese, sendo que cinco delas relacionam-se ao funcionamento geral do conselho:

Questão 01. Você pode me explicar qual o papel do conselho na prática?

Questão 02. Quais são as suas atividades como conselheiro?

Questão 09. Pela sua experiência, quais são as principais vantagens decorrentes da existência do conselho?

Questão 10. E quais são as principais dificuldades para o funcionamento do conselho?

Questão 15. Na sua opinião, existe uma diferença de atuação entre os conselheiros que são funcionários e gestores públicos e os da sociedade civil?

Outras quatro são relacionadas diretamente à informação para a tomada de decisão:
Questão 11. Você acha que os conselheiros são suficientemente informados para participar do conselho?

Questão 12. Como você se mantém informado?

13 Ministrada na Faculdade de Saúde Pública pelos professores Fernando Lefèvre e Ana Maria Cavalcanti Lefèvre em janeiro de 2008 e que teve participação de membros da equipe, inclusive da autora desta tese.

${ }^{14}$ A primeira é formada por um grupo de questões que caracterizam os conselheiros quanto à idade, profissão, tempo de conselho, local de moradia, escolaridade, entre outros. A segunda parte é composta de 20 questões qualitativas que, como foi explicado, fornecem material para diversas pesquisas do grupo MEGA. Por fim, a terceira parte é um questionário quantitativo sobre governança que subsidiou um mestrado dentro do escopo do projeto. Alguns pesquisadores concentraram seus trabalhos em um dos conselhos pesquisados, enquanto outras pesquisas, como esta, definiram temas que foram trabalhados transversalmente nos quatro conselhos [ANEXO 2]. 
Questão 13. Que tipo de informação você acha que deveria receber para melhorar a qualidade da sua atuação no conselho?

Questão 14. De que forma você acha que estas informações poderiam chegar até você?

Antes de ir a campo, pesquisadoras do projeto MEGA ${ }^{15}$ realizaram pré-testes da entrevista com o objetivo de avaliar a compreensão das perguntas pelos entrevistados e verificar o tempo de aplicação dos questionários, de modo a poder programar a ida a campo. O pré-teste foi realizado com três conselheiros do Conselho Municipal de Meio Ambiente e Desenvolvimento Sustentável - CADES do município de São Paulo. Os problemas encontrados foram corrigidos ${ }^{16}$.

Durante a pesquisa buscou-se entrevistar os conselheiros titulares, tanto do poder público, quanto da sociedade civil nos quatro conselhos. Por motivos de diferenças no período do mandato e de organização das atas entre os conselhos houve adaptações na forma de definição dos nomes a serem entrevistados em cada um deles, como segue:

No CMPU houve a intenção de entrevistar todos os titulares. Após cessadas as tentativas de contato com estes conselheiros, foram contatados os suplentes com maior participação nas reuniões segundo as atas do conselho. Foram entrevistados 15 conselheiros do poder público e 14 da sociedade civil.

No COMUGESAN o critério para a seleção dos conselheiros foi a freqüência às reuniões, verificada pelas atas. Foram entrevistados 15 conselheiros do poder público e 15 da sociedade civil.

\footnotetext{
15 Entre elas a autora desta tese.

${ }^{16}$ No segundo semestre de 2008 a equipe, formada por cinco pesquisadores, foi a campo entrevistar os membros dos quatro conselhos municipais selecionados de Santo André
} 
No CMO também se partiu da meta de entrevistar todos os titulares. Junto à sociedade civil considerou-se o mandato anterior, uma vez que o mandato em vigor estava no início e os conselheiros não tinham adquirido experiência. Após esta etapa, buscou-se substituir os conselheiros que não foram localizados ou que não puderam conceder entrevista por membros da gestão vigente que tinham participado em outros mandatos do conselho. Com relação aos conselheiros do poder público, utilizou-se também o critério de entrevistar os titulares, e quando necessário, foram substituídos por suplentes. Foram entrevistados 14 conselheiros do poder público e 15 da sociedade civil.

No CRPPA, buscou-se entrevistar os conselheiros que tiveram maior freqüência às reuniões e que estavam a mais tempo no conselho. Foram realizadas 16 das 18 entrevistas programadas, sendo 8 conselheiros do poder público e 8 da sociedade civil [tabela 1].

Tabela 1: consolidação do número de conselheiros entrevistados.

\begin{tabular}{|c|c|c|c|c|}
\hline & \multicolumn{2}{|c|}{ CMPU } & \multicolumn{2}{|c|}{ COMUGESAN } \\
\hline & Total & Entrevistado & Total & Entrevistado \\
\hline Poder público & 19 & 15 & 15 & 15 \\
\hline \multirow[t]{3}{*}{ Sociedade civil } & 19 & 14 & 15 & 15 \\
\hline & \multicolumn{2}{|c|}{ CMO } & \multicolumn{2}{|c|}{ CRPPA } \\
\hline & Total & Entrevistado & Total & Entrevistado \\
\hline Poder público & 19 & 14 & 9 & 8 \\
\hline Sociedade civil & 19 & 15 & 9 & 8 \\
\hline
\end{tabular}

Fonte: Preparada pela autora, 2010.

Foram ao todo realizadas 104 entrevistas para esta etapa do trabalho. As entrevistas foram gravadas com o consentimento prévio dos entrevistados, observando-se os aspectos éticos, de acordo com a resolução CNS 196/96 da FSP.USP [anexo A]. Os roteiros de entrevista e questionário 
utilizados foram submetidos ao comitê de ética desta faculdade sob protocolo 1599 e aprovados em julho de $2008^{17}$.

\subsubsection{Tratamento dos Dados}

As entrevistas aplicadas geraram respostas qualitativas e abrangentes. Para sua análise, as respostas foram separadas por conselho, dado que foram quatro conselhos pesquisados, e, em cada conselho, classificadas por representação - conselheiros do poder público e da sociedade civil. Em seguida, cada uma das respostas foi ouvida, buscando-se os significados nela inseridos [figura 1 " fase descritiva]. Para cada um desses significados foram criadas categorias. Estas categorias permitiram que se obtivesse uma visão de conjunto e que se quantificasse a freqüência de cada categoria por grupo. Por fim, foram realizadas as comparações entre os diversos grupos e a teoria correspondente [figura 1 - fase explicativa].

Este procedimento de análise encontra respaldo teórico no método de interpretação desenvolvido por Minayo (2008) onde a autora estabelece etapas de interpretação de dados qualitativos; nesta interpretação primeiro compreende-se o contexto sócio-histórico do grupo social entrevistado; em seguida, organizam-se os dados, classificando-os por categorias. Por fim, articulam-se os dados com a teoria. Também o procedimento de análise utilizado encontra-se em ressonância com a técnica da criação do "Discurso do Sujeito Coletivo"18, que separa as questões, cria categorias para classificar as respostas, quantifica a freqüência do

17 O pedido foi encaminhado pelo Projeto MEGA ao comitê de ética da Faculdade.

18 Este "Discurso do Sujeito Coletivo" é composto com trechos de respostas organizados na forma de "discurso". Para esta técnica existe um software que facilita o procedimento, o Qualiquantisoftware (LEFĖVRE; LEFĖVRE, 2003). Mesmo buscando respaldo teórico na técnica do Discurso do Sujeito Coletivo para a forma de análise das respostas às questões qualitativas, esta pesquisa não gerou o discurso proposto por entender que tal recurso não contribuiria para a qualidade dos resultados específicos deste trabalho. 
aparecimento de cada categoria de resposta no conjunto dos entrevistados e, permite a geração de um discurso de um "sujeito" que representa aquela categoria de resposta.

Nas quantificações das respostas quatro situações geraram respostas não válidas: quando o entrevistado não respondeu a pergunta; quando o entrevistado respondeu algo que não tem relação com a pergunta; quando a resposta foi induzida pelo entrevistador; e quando o entrevistador pulou a pergunta.

Por fim, foi desenvolvida a análise e discussão dos dados, com luz na base teórica desenvolvida; e foram delineadas as conclusões [figura1 - fase explicativa]. 


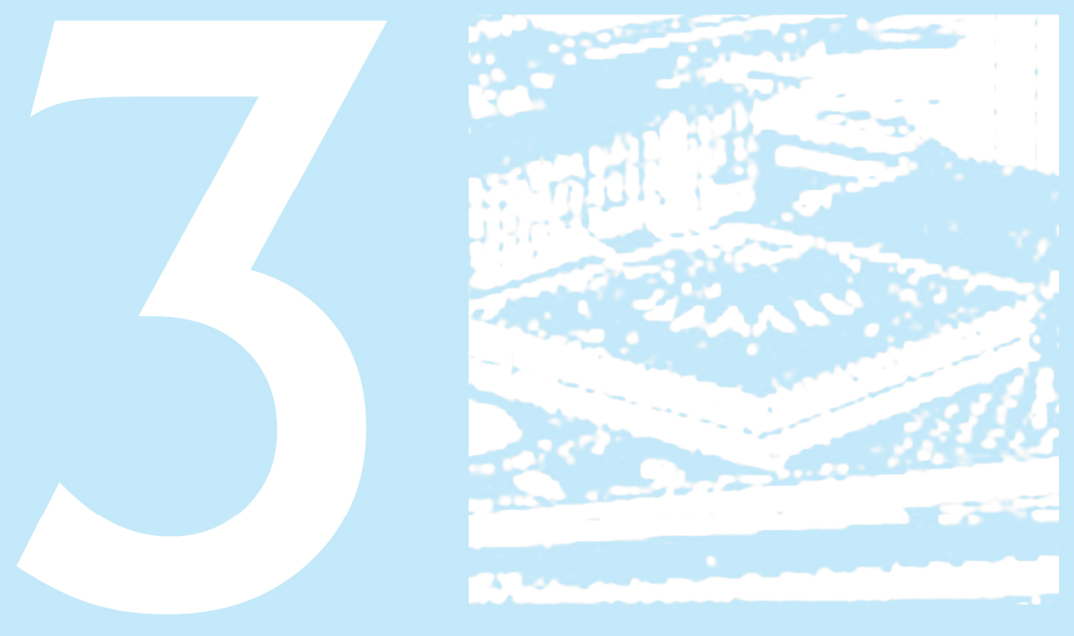

2

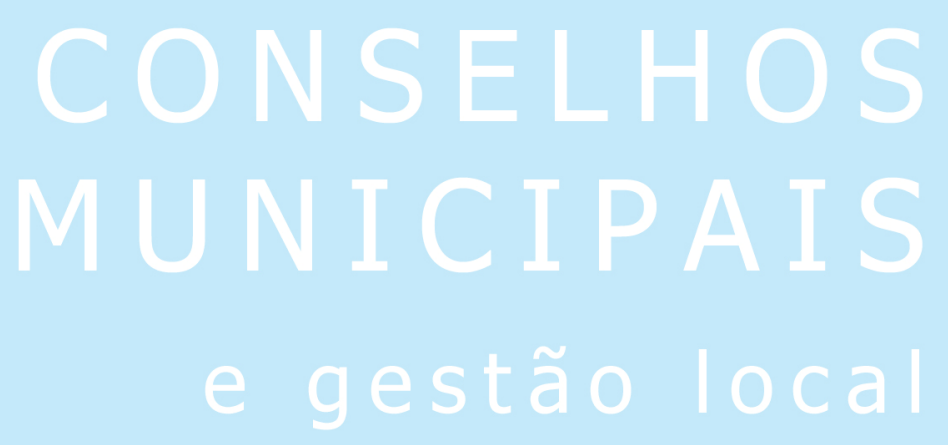





\section{CONSELHOS MUNICIPAIS E GESTÃO LOCAL}

Neste capítulo são apresentados os referenciais teóricos utilizados para a discussão dos resultados da pesquisa. Inicia-se com 0 objetivo de promover o desenvolvimento sustentável na área urbana, considerando a implementação de políticas públicas municipais. No contexto da globalização, o enfraquecimento do poder do Estado e o aumento da participação social abriram espaço para que fossem criados os conselhos municipais como instituições híbridas para a gestão de políticas públicas. São estes conselhos o foco desta tese.

\subsection{DESENVOLVIMENTO SUSTENTÁVEL}

Na década de 1960, as grandes obras de engenharia, tais como represas, complexos industriais, usinas nucleares, entre outras, trouxeram impactos negativos ao meio ambiente. Também ocorreram grandes desastres como o vazamento de petróleo de Santa Bárbara nos Estados Unidos que poluiu extensas áreas. Isto associado à força de estudos apresentado no livro Primavera Silenciosa em 1962 (CARSON, 1964) e o Limites do Crescimento em 1972 (MEADOWS, 1974) que evidenciavam a fragilidade e os limites dos ecossistemas naturais, assim como os efeitos cumulativos da poluição, alertando para uma crise ambiental planetária.

Como resposta à percepção desta crise entrou em vigor nos Estados Unidos em $1^{\circ}$ de janeiro de 1970 o "National Environmental Policy $A c t^{\prime \prime}$ (NEPA), como a primeira lei ambiental de caráter preservacionista que procurou controlar os impactos negativos no ambiente. Nesta mesma época, como resposta às questões ambientais emergentes, a ONU passou a realizar 
sistematicamente conferências para discutir os problemas ambientais. A primeira "Conferência da Nações Unidas para o Ambiente Humano" foi realizada em Estocolmo em 1972 e nela determinou-se a criação do Programa das Nações Unidas para o Meio Ambiente (PNUMA). As diversas constituições nacionais elaboradas depois deste evento passaram a inserir em seu texto o direito do cidadão a um meio ambiente saudável, incluindo a brasileira, homologada em 1988, considerada uma das mais avançadas em matéria ambiental (MILARÉ, 2004).

Na década de 1980, no Brasil, o Sistema Nacional de Meio Ambiente (SISNAMA) foi criado em 1981 através da Lei Federal número 6.938/1981, instituindo um sistema para tratar do ambiente, com a participação de um conselho nacional, o CONAMA, que reúne membros do poder público e sociedade civil, ampliando a participação da população em geral. Nesta mesma década, a ONU delegou a uma comissão chefiada pela primeira ministra da Noruega, Gro Brundtland, a tarefa de reexaminar os principais problemas ambientais e de desenvolvimento do planeta sob 0 ponto de vista da sustentabilidade. O resultado foi apresentado na forma de relatório intitulado "Nosso Futuro Comum", apontando que o crescimento econômico e ambiental está próximo do limite da capacidade de sustentação do meio ambiente. $E$, por isto, este documento enfatiza a necessidade de poder contar com o desenvolvimento sustentável como sendo "aquele que atende às necessidades do presente sem comprometer a possibilidade de as gerações futuras atenderem a suas próprias necessidades" (BRUNDTLAND, 1991, p.46). Em seguida, a autora delimita duas características principais do documento: a primeira diz respeito às necessidades, com enfoque àquelas essenciais dos pobres que devem receber a maior prioridade; a segunda é a "noção das limitações que o estágio da tecnologia e da organização social impõem ao meio ambiente, impedindo-o de atender às necessidades presentes e futuras" (BRUNDTLAND, 1991, p.46). Para Foladori (1999) a primeira destas características está relacionada à equidade das gerações 
presentes e tem caráter social, enquanto a segunda, tem relação com a garantia de um mundo físico para as futuras gerações - como está atualmente ou melhor - tendo assim caráter técnico. Desse modo, para se alcançar a sustentabilidade, necessita-se buscar a eqüidade intra e intergeracional (VOJNOVIC, s/d).

A mais importante destas convenções internacionais, foi a denominada "Cúpula da Terra", "Rio 92" ou "Eco-92", que aconteceu na cidade do Rio de Janeiro no ano de 1992, enfatizando o controle dos impactos das atividades humanas, controle esse a ser realizado por intermédio da Agenda 21. Este é um documento que propõe objetivos a serem alcançados durante o século XXI, seja por meio de mitigações ou pela ausência de impacto negativo no meio ambiente, sendo, por isto, tida como cartilha básica para o desenvolvimento sustentável (MILARÉ, 2004). Nos diálogos que se seguiram à Agenda 21, incluiu-se o aspecto social como indissociável dos aspectos econômicos e ambientais da sustentabilidade, de modo que haja coexistências destes três fatores: sustentabilidade ambiental, sustentabilidade econômica e sustentabilidade social, resultando assim naquilo que vem sendo chamado sustentabilidade ampliada (BEZERRA; FERNANDES, 2000).

Alguns autores incluem também outros elementos como essenciais para a sustentabilidade. Dentre estes, os mais citados são o elemento territorial (MAGNAGHI, 1998), que considera a importância do sítio, o elemento cultural e o institucional (BEZERRA; FERNANDES, 2000). Considera-se a inter-relação territorial e ambiental, uma vez que o território que dá suporte a uma ocupação faz parte do ambiente e, portanto, está incluído nas considerações ambientais. O elemento cultural refere-se ao respeito à cultura das populações envolvidas, tanto no seu modo de vida, quanto em relação a seu patrimônio, sua preservação e relacionamento com outras culturas. Esta atenção também está incluída no aspecto social da sustentabilidade. É importante ressaltar que, condições institucionais 
favoráveis são realmente necessárias para qualquer forma de desenvolvimento, incluindo o sustentável. Então, a institucionalidade é condição de sustentabilidade e não um de seus fatores.

O desenvolvimento sustentável é aquele que é socialmente justo, ambientalmente correto e economicamente viável, ou seja, apóia-se no tripé social, ambiental e econômico. Deste modo, para se alcançar a sustentabilidade necessita-se buscar a equidade intra e inter geracional, o que significa dizer: potencializar os três aspectos da sustentabilidade, tanto para promover a equidade para a população atual do planeta, quanto para manter essas condições para que as populações futuras também possam manter sua qualidade de vida.

Discute-se muito em que condições haverá sustentabilidade e quando esta será alcançada, principalmente ao se focalizar as diferenças intergerações, ao mesmo tempo em que as intragerações com relação às questões ambientais, sociais e econômicas (LEE, 2006).

O desenvolvimento sustentável tem, como foi mostrado, três aspectos principais. Dada a flagrante urgência dos problemas mundiais, como o do aquecimento global ou a produção de alimentos para a crescente população, alguns autores preferem priorizar o aspecto social, por considerálo o mais relevante, uma vez que envolve a qualidade de vida da população. Esta é a postura adotada aqui, porém, considera-se que, para se obter a plena satisfação da equidade social, o aspecto econômico e o ambiental devem ser atendidos, como segue. O econômico deve dar suporte à realização pessoal, gerando emprego, promovendo a inovação e desenvolvendo a tecnologia, criando espaços em que o desenvolvimento do indivíduo seja possível. Fala-se mais sob a forma de igualdade de oportunidades que de igualdade de condições, levando ao desenvolvimento e à satisfação pessoal, com ética e dignidade para cada indivíduo. Portanto, as ações desenvolvimentistas socialmente justas precisam fornecer tais 
condições, sendo economicamente viáveis. Com relação ao meio ambiente, este precisa ser saudável e utilizado dentro dos limites que permitam, tanto manter a diversidade biológica, quanto os serviços insubstituíveis prestados por ele, tais como assimilação de dejetos ou produção de alimentos, de forma que todas as pessoas tenham condições dignas de vida. Recursos como energia e alimentos, ambiente saudável, estabilidade climática, descarte dentro das possibilidades de absorção do ambiente, devem ser empregados de forma que seja possível uma vida digna para a geração atual e para as gerações futuras, como garantia de qualidade de vida, o que também é um objetivo social.

A qualidade das condições de vida da sociedade é o alvo, mas a atenção também não pode ser desviada dos fatores econômicos e ambientais. Os estudos mais amplos realizados por Meadows (1974), Meadows (et al., 2008) e Brundtland, (1991) indicam que os recursos ambientais, associados ao tamanho da população, sua taxa de crescimento, seu estilo de vida, bem como à tecnologia disponível fatalmente atingirão um ponto de ruptura em que a população total não pode mais ser atendida. É necessário encontrar um novo equilíbrio, por isto é preciso desenvolver uma forma de atingi-lo.

A teoria da modernização ecológica apresentada por Mol (2000) surgiu a partir de pesquisas das áreas de sociologia ambiental e outros cientistas sociais que tinham como objeto de estudo a deterioração e reforma ambiental. Diz respeito às mudanças de abordagem destes acadêmicos que aconteceram, tanto no discurso ambiental, quanto nas práticas sociais e nas instituições que lidam com o meio ambiente. Apesar de não existir um pensamento único entre os estudiosos, existem pontos em comum, que dizem respeito: ao papel da ciência e tecnologia como potencial contribuintes para a solução e prevenção dos problemas ambientais; a importância da participação de atores de mercado e do governo para a reestruturação ecológica; a mudança do governo central tradicional para um 
formato mais descentralizado, flexível e consensual, abrindo oportunidades para atores não estatais; à não aceitação de discursos que contrapõem os interesse econômicos e ambientais, assim como aqueles que pregam 0 completo negligenciamento do meio ambiente (MOL, 2000).

O fato é que a noção de sustentabilidade está cada vez mais amalgamada com à de desenvolvimento. Depois da Rio 92, pode-se notar duas tendências principais: houve um "esverdeamento" dos projetos para que recebam investimentos das agências multilaterais; houve um esforço das Organizações Não Governamentais (ONGs) em substituir a idéia de progresso pela de sustentabilidade, como uma forma de organizar o desenvolvimento "centrado no povo" (ACSELRAD, 2009, p.44).

As diversas abordagens do tema desenvolvimento sustentável são tratadas por Frey (2001, p.13). Neste artigo o autor apresenta três vertentes: uma econômico-liberal, defendida pelo relatório Brundtland, que, segundo o autor não traz propostas de adequação dos processos decisivos nem das condições de poder existentes, abrindo a possibilidade de teóricos neo-liberais utilizarem esta vertente para defender 0 seu modelo 'laissez-faire' de capitalismo; a segunda ecológico-tecnocrata de planejamento, aponta os limites do meio ambiente em suportar o desenvolvimento da forma que vem acontecendo, e se apóia na "expertise" profissional para planejar os caminhos para a adequação a esses limites ambientais, que pode ser de forma criativa e holística, como defende Sacks ${ }^{19}$, ou conservadora, como defendida por Ophuls; a terceira abordagem, denominada "Sustentabilidade estribada na sociedade: a abordagem política de participação democrática", considera que as redes de

19 Em seu livro "Desenvolvimento includente, sustentável e sustentado", Igancy Sachs apresenta uma série de artigos que tratam do desenvolvimento de países não desenvolvidos.Nele o autor desenvolve questões importantes como o Emprego como forma de inclusão social, e apresenta um caminho de política para alcançar este objetivo baseado na produção de biomassa, valorização dos recursos internos destes países e na transformação de empregos de baixa produtividade em empregos de alta produtividade (SACKS, 2004). 
negociação põem cada vez mais pressão no sistema político e a democracia representativa se mostra insuficiente para lidar com estas novas exigências. O Planejamento é entendido "não apenas como orientado pelas necessidades da população, mas também conduzido por ela". Assim, pode-se dar condições para que haja o empoderamento da população, transformando o poder social em poder político.

Por estes exemplos aqui citados, pode-se notar cada vez mais a sólida ligação entre as questões puramente ambientais - como a de Mol e as de desenvolvimento sustentável como as de Acselrad e Frey - com as práticas socialmente inclusivas, tanto em seus propósitos, quanto na forma de ação, que requer a participação dos diversos atores para a construção de estratégias de ação.

Um aspecto chama atenção de Acselrad (2009, p.45): 0 termo sustentabilidade ainda está vago e é tido e utilizado como "algo bom, desejável, consensual". Por isto, a definição de sustentabilidade que sobressair será utilizada para "que se discriminem, em seu nome, as boas práticas das ruins". Tem-se então a idéia de processo relacionada à de sustentabilidade, uma vez que, para se poder dizer se algo é sustentável ou não, é necessário recorrer a uma comparação no tempo entre o presente e o futuro esperado.

Também a expressão desenvolvimento sustentável, segundo Foladori (1999) apesar de rica em significados, também é vaga; e segundo Costa (1999) tem sido generalizada pelo "senso comum", o que faz pensar na relação entre estes termos. O conceito de desenvolvimento sustentável tem servido como "guarda-chuva", abrangendo diversas propostas que caminham na direção de uma maior justiça social, de ambientes mais saudáveis e de relações de "compromisso com o futuro". Isto traz duas conseqüências: a associação do conceito com projetos de diversas abordagens, mas que trazem um núcleo comum; e a banalização do termo 
decorrente de seu uso freqüente e impreciso, natural dos termos da moda (COSTA, 1999).

De fato, apesar de existirem eixos orientadores para 0 desenvolvimento sustentável, não se sabe ainda ao certo como seria a sociedade resultante desta forma de desenvolvimento. Há, porém, indicações de processos que podem conduzir a uma aproximação do modelo de conquista de uma sociedade justa com vitalidade econômica e qualidade ambiental. Esta tese trabalha com a perspectiva de que as políticas públicas, e os planos de ação decorrentes, devem cumprir parte relevante deste desafio, como será apresentado.

\subsection{O DESENVOLVIMENTO SUSTENTÁVEL E AS CIDADES}

A cidade se caracteriza por ser o local da concentração: concentração de pessoas que acarreta na concentração de atividades antrópicas. Também é nas cidades que há concentração de riqueza e conhecimento. É nelas que se manifestam as oportunidades, empregos, instituições de ensino, opções de lazer, os fluxos sociais, culturais econômicos e de poder (ALVA, 1997). Assim, não é de se espantar que as cidades atraiam a juventude rural e estimulem a migração rural-urbana. Entretanto, ao se pensar no ambiente urbano apenas como ambiente construído, nota-se que seriam raros os ambientes não urbanos. As áreas rurais, por exemplo, seriam espaços com características urbanas principalmente no que diz respeito às relações sociais nelas presentes (COSTA, 1999). O desenvolvimento sustentável urbano, de fato, é difícil de ser separado do desenvolvimento sustentável rural. Alguns autores julgam irrealista restringir os estudos de sustentabilidade urbana às cidades (ACSELRAD, 2009). 
Costa (1999) apresenta duas formas de aproximação do tema da sustentabilidade urbana: a primeira se apóia em dados estatísticos como que no início do século XX, apenas $10 \%$ da população mundial vivia em cidades, e que no final desse mesmo século praticamente metade da população do planeta situa-se em área urbana e ainda, que esta proporção continua crescendo (SIRKIS, 2003) -; a outra, preferida pela autora, se apóia no fato de o espaço urbano ser o resultado material das relações sociais, e ser um agente transformador destas relações. Estes são dois motivos para se trabalhar com a sustentabilidade urbana.

O desenvolvimento sustentável, apesar de ser uma demanda mundial, tem especificidades condizentes com as inúmeras realidades locais do planeta. Assim sendo, diversidade de culturas, ecossistemas, vocações econômicas, riquezas locais e sistemas de gestão pública fazem com que este tipo de desenvolvimento necessite da atenção local, do detalhe e do específico. As cidades, por serem o ponto de concentração dos povos com suas culturas, economias, instituições e demandas ambientais, e por serem normalmente o menor nível de governo com autonomia, são a escala mais apropriada de intervenção para o desenvolvimento urbano sustentável.

Com a ressalva da imprecisão dos termos ligados à sustentabilidade, pode-se buscar esclarecer 0 que vem a ser desenvolvimento urbano sustentável. Para Acselrad (2009), a aplicação da noção de sustentabilidade no desenvolvimento das cidades expressa um movimento duplo. De um lado, os diversos atores sociais das cidades incorporam em suas discussões e práticas a questão ambiental. Por outro lado, as agências multilaterais incluem em suas exigências que projetos de desenvolvimento urbano e de infra-estrutura, entre outros, incorporem a solução dos entraves ambientais que geram.

Existe novamente um aspecto vago no termo desenvolvimento urbano sustentável segundo Costa (1999) e Acselrad 
(2009). Uma conseqüência desta imprecisão pode ser o seu uso como "rótulo de marketing' entre as cidades no panorama da competição global em que estão inseridas.

Para Costa (1999) não se pode dizer que exista uma forma urbana típica da era informacional, pós-moderna, como havia na era industrial. Há, segundo Acselrad (2009), uma movimentação por parte de agentes sociais que buscam construir uma rede mundial de cidades sustentáveis, visando elaborar seus atributos. Porém considera-se que existem premissas com relação à espacialização das cidades sustentáveis. Nenhuma proposta de centros urbanos sustentáveis aprova o espraiamento da mancha urbana, o uso de automóveis, a separação rígida de usos do solo e a segregação espacial das classes sociais. Existem propostas espaciais bem detalhadas como é o caso das cidades compactas ou do novo urbanismo que expressam estes valores.

A cidade compacta é resultante da visão européia das cidades sustentáveis, onde: as centralidades são tanto definidas quanto servidas por nódulos de transporte público, nos pontos mais densos da mancha urbana; existe mistura de usos que busca evitar o deslocamento para os assuntos do dia a dia; suas fronteiras são definidas de forma a evitar o espraiamento da mancha urbana; e buscam-se formas de eficiência na utilização de recursos energéticos e de transporte. Esta cidade é planejada em oposição à mancha urbana fragmentada e não densa que é geradora de tráfego, energeticamente dispendiosa e ineficiente com relação às redes de infra-estrutura e serviços públicos (ROGERS, 2001). O movimento das cidades sustentáveis da Califórnia, apresentado por Costa (1999), trabalha com a associação de grupos da sociedade civil organizada que atuam na área ambiental com agências governamentais, buscando construir uma área metropolitana sustentável. Seus princípios urbanos têm semelhanças com as demais iniciativas de cidades sustentáveis: a contenção do espraiamento urbano; a mistura de usos nos bairros para diminuir o deslocamento diário 
da população; o incentivo ao transporte público; a ocupação dos vazios urbanos; entre outros. O que torna a experiência interessante, e mais próxima das tentativas brasileiras de desenvolver centros urbanos mais sustentáveis é a forma participativa. Nas palavras de Costa (1999, p.66) "[...] o que torna o caso interessante é o fato de ele representar o acordo possível, a consolidação de um processo de discussão envolvendo diretrizes e estratégias das diversas organizações e agências governamentais que de fato atuam na região".

O desenvolvimento urbano sustentável incorpora os conceitos de cidades sustentáveis, expressos, por exemplo, pelas cidades compactas, e avança na forma de gestão que deve incluir a participação dos atores sociais, incluídos aqui os de mercado, na discussão com o Estado objetivos comuns para a cidade, buscando acabar com a segregação espacial e democratizando os serviços em bases ambientalmente responsáveis.

No caso da promoção da sustentabilidade urbana as ações se organizam, em grande parte, na forma de novos paradigmas e valores. Estudando os mecanismos para se conseguir intervir em um determinado sistema com eficiência, Meadows (1997) chama atenção para os pontos de alavancagem. Para esta autora, a forma mais eficiente de conseguir mudanças significativas é transcendendo paradigmas; isto leva tempo para ser incorporado pela cultura da população. No entanto, alguns atores sociais podem contribuir para esta mudança de postura, como, por exemplo: as ONGs, igrejas, escolas e até a mídia, que trazem contribuições ao processo educativo, facilitando a tarefa da política educacional. Deste modo, é através da gestão ambiental urbana que se procura garantir o avanço do processo de promoção do desenvolvimento sustentável. 


\subsection{O NOVO CONTEXTO MUNDIAL}

Na mesma época em que o conceito de desenvolvimento sustentável emergiu, década de 1980, outro fenômeno mundial também eclodia como processo irreversível que afeta a todos: a globalização. Para Eaty e Ivanova (2005) a globalização é um fenômeno que influencia o comportamento humano e, por si só, não é boa nem má, mas deve ser compreendida e administrada. Como acontece com os termos ligados à sustentabilidade, globalização é uma palavra da moda, e é preciso cuidado ao utilizá-la, uma vez que, segundo Bauman (1999), tem o destino de explicar muitas experiências e tornar-se imprecisa. 0 termo globalização "refere-se primordialmente aos efeitos globais, notoriamente não pretendidos e imprevistos, e não às iniciativas e empreendimentos globais" (BAUMAN, 1999, p.67). Para Acselrad (2009) as cidades têm um papel cada vez mais importante para a acumulação de capital e, ao mesmo tempo, são afetadas pelos efeitos da reestruturação produtiva ${ }^{20}$ e da globalização em seus sistemas de transporte urbano, assim como pela segregação espacial. Tornase necessário mostrar aqui qual a influência da globalização na forma como os municípios são governados neste início de século XXI.

A produção mundial está fortemente concentrada em grandes empresas. Aproximadamente um quarto de tudo o que é produzido no planeta é feito por cerca de 500 grandes companhias. Estas empresas se organizam em grandes redes que se fazem sentir até nos mais longínquos

\footnotetext{
20 "O processo de reestruturação produtiva foi a reorganização do sistema e dos processos produtivos e a reorganização dos sistemas de gestão que vieram como resposta aos problemas de crise econômica mundial da década de 1970 (como a queda na produtividade industrial). [...] Com o processo de reestruturação produtiva, houve a "fragmentação organizacional do processo de produção", resultando na descentralização da atividade produtiva e no aumento da racionalização dos processos, culminando com o fechamento de um grande número de fábricas. Nesse processo de "externalização difusa das atividades produtivas" as unidades produtivas passam a ser menores e menos especializadas" (MARQUES, 2010, p.29 e 30) (BRUNA, 2006).
} 
municípios (DOWBOR, 2003). Dada a compressão espaço/tempo descrita por Harvey (2004) em que a velocidade de movimentação aumenta, uns se movem mais rápido do que outros. A economia se move instantaneamente, o que a torna livre das restrições espaciais, do território. Os mecanismos da política econômica deixaram de funcionar uma vez que o capital não tem mais endereço físico, e os fluxos financeiros ficaram fora do controle dos governos nacionais. Os Estados não controlam mais a economia e existe um caráter de anonimato destas forças internacionais (BAUMAN, 1999). Tem-se então que, se os Estado não têm soberania total, eles não são mais as únicas unidades importantes nas relações internacionais (KJAER, 2004).

Na década de 1980, uma onda de reformas do setor público caracterizada por privatizações, principalmente nos países ocidentais, transferiu para o setor privado atividades características do setor público. Houve a transferência para organizações supra-nacionais por parte do poder dos Estados. As organizações da sociedade civil ficaram mais envolvidas com os serviços públicos e estas mudanças resultaram numa grande fragmentação do sistema político (KJAER, 2004). Houve, então, o surgimento de ONGs de âmbito global, muitas criadas para suprir demandas ambientais. Estes fenômenos descritos ganham expressão e as nações passam a ter que lidar com esta nova realidade de compartilhamento de poder no nível global. Associa-se a este contexto a crise econômica que aconteceu naquela época. Este cenário provocou uma forte pressão sobre os governos de cima para baixo.

Ainda na mesma década de 1980, o Brasil passava por uma quebra do crescimento econômico do período militar e por um grande endividamento do governo, isto associado à explicitação dos problemas urbanos relacionados à desigualdade. Estes fatores convergiram para os fortes movimentos de redemocratização do país (ALVIM et al., 2007). Este contexto nacional, também provocou uma forte pressão, mas esta, de baixo para cima. 
Estas pressões, tanto de cima para baixo, quanto de baixo para cima, foram exercidas não apenas no Brasil, mas sobre os diversos governos nacionais. Na América Latina, por exemplo, houve vários governos autoritários que deram lugar a governos democráticos nas décadas de 1970 e 1980. As nações foram compelidas a repensar as relações entre sociedade e governo. Para Santos Junior (2001) foram três os fenômenos comuns a muitos países da América Latina. Além da democratização de diversos Estados nacionais, antes regidos por regimes militares, as economias nacionais buscaram inserir-se no movimento de globalização e a esfera local foi revalorizada como a escala apropriada para a promoção do desenvolvimento social. O Estado, como agente que reivindica o monopólio dos meios de coerção e do uso deles em seu território soberano, como define Max Weber já não atende mais às necessidades (BAUMAN, 1999). Há uma pressão sobre os governos para incorporarem novas formas de gestão que se distanciem dos modelos tradicionais e autoritários, formas essas que insiram participação da sociedade e maior transparência (SILVA; CRUZ; MELO, 2007). Gohn (2007a, p.36), quando aborda esta problemática, resume da seguinte forma:

[...] a ampliação da esfera pública, por parte de setores organizados da sociedade civil em luta pela construção de suas identidades, e os efeitos das reformas que configuram novo papel para o Estado na sua relação com a sociedade criaram os elementos para a constituição de um novo conceito na ciência política: o de governança.

O conforto de saber que as coisas estavam pelo menos controláveis tecnicamente, que havia um painel de controle, um centro, uma comissão diretora em um centro administrativo com o qual acostumou-se durante a era moderna, foi rompido. "Ninguém parece estar no controle agora" (BAUMAN, 1999, p.66). É exatamente esta perda de poder sentida pelos governos que os fez fomentar a participação popular na produção de políticas públicas, como forma de buscar neutralizar as práticas predatórias entre agentes públicos e cidadãos (BOSCHI, 1999). 
Neste novo posicionamento do Estado há uma transferência parcial de poder do governo para a sociedade civil. O antigo estado prestador de serviços torna-se co-produtor do bem público. Ele não é mais responsável por oferecer sozinho todos os serviços. Ele pode, através de parcerias ou contratos transferir para os agentes sociais ou o setor privado algumas ações. Ainda assim, o Estado é o responsável por garantir tais serviços. Trata-se então de uma alternativa para a velha gestão baseada na hierarquia (KISSLER, HEIDEMANN, 2006). Quanto às políticas públicas, 0 governo passa a ser apenas um dos atores envolvidos nos processos de formulação, implantação e avaliação, fazendo com que os contornos entre público e privado fiquem turvos (STOKER, 1998).

Putnam (2006, p.24) apresenta um modelo simples de desempenho institucional: "demandas sociais $\rightarrow$ interação política $\rightarrow$ governo $\rightarrow$ opção de política $\rightarrow$ Implementação". Nele, os cidadãos têm suas demandas e os partidos políticos junto com outros grupos articulam as prioridades. Às autoridades cabe, quando muito, deliberar sobre o que fazer e, se a opção não for "não fazer nada", adotar uma política para tanto, e implementá-la. Há a necessidade de sensibilidade e eficácia na utilização dos recursos, normalmente limitados, para atender às demandas.

\subsection{GOVERNANÇA}

As definições mais espontaneamente utilizadas de governança remetem à democracia local, com a participação cidadã no centro. O debate sobre governança aborda principalmente as relações entre a sociedade civil e os poderes locais (BOURDIN, 2001). A extensão do conceito de governança não está bem definida. Pode ir do mais restrito administração - ao mais amplo - poder público. Isto traz uma controvérsia 
na forma e no conteúdo obrigatório da governança (OSMONT, 1998). Governança tem sido tratada como um conceito suficientemente amplo para incluir o governo, indivíduos, instituições públicas e privadas para administrar os problemas comuns. Isto pode acontecer de maneira formal e institucional, mas pode também ser informal. Em função do almejado estabelecimento de objetivos comuns, raramente é necessária a utilização da coerção para a implantação das decisões tomadas neste tipo de processo, o que é útil para um Estado enfraquecido. Para Kissler e Heidemann (2006), esta alteração na forma de gestão política posiciona o Estado como ativador dos processos participativos de resolução dos problemas, o que valoriza o papel do setor privado e do terceiro setor perante o setor público. Gohn (2007a) afirma que foi justamente a perda de algumas funções do Estado que induziu o surgimento de diversas arenas de discussão geradas pelas parcerias entre 0 setor público e o "privado-comunitário". "[...] A governança foi criada para dar conta dos novos processos que as políticas de globalização impuseram, enfraquecendo o conceito, então vigente, de governabilidade" (GOHN, 2007a, p.37).

Souami (1998) faz uma crítica considerando vago o conceito de governança. Para ele a participação da população e a democracia local são evocados de forma evasiva e cheia de precauções. O autor afirma que a finalidade é indeterminada e o objetivo encantador. O governo é aberto a todos os atores do urbano para a negociação e coordenação das ações e dos meios.

Para Habermas (2009) existe um ganho importante no resultado de ações de diversos atores quando estas se baseiam na comunicação horizontal. O autor parte da distinção entre trabalho e interação para explicar este fenômeno e afirma que o trabalho é uma ação instrumental, orientada por regras técnicas e saber empírico, combinada com uma escolha racional, orientada por estratégias e saber analítico. Esta ação racional parte de condições dadas para realizar fins definidos, organizando os 
meios adequados segundo critérios de controle eficiente da realidade. Esta é a forma pela qual o homem se emancipa progressivamente da natureza. A ação racional distingue-se da ação comunicativa dada pela interação seguindo "normas de vigência obrigatória". Nesta comunicação existem expectativas recíprocas de comportamento que precisam ser entendidas e reconhecidas entre os "sujeitos agentes". As normas sociais são criadas através das relações entre os sujeitos. Nos dois casos o não cumprimento das regras tem conseqüências diferentes. Violar as regras técnicas da ação instrumental leva a um fracasso perante a realidade por não se conseguir o que se pretende. Um comportamento "desviado" que viola as regras da ação comunicativa provoca sanções, que estão vinculadas às normas apenas por convenção. Aprender a lidar com estas regras requer um aprendizado de habilidades. "As habilidades capacitam-nos a resolver problemas e as motivações permitem-nos praticar a conformidade com as normas" (HABERMAS, 2009, p.57-58). Pode-se distinguir os sistemas sociais pelo tipo de ação - instrumental ou comunicativa - que predomina. A ação comunicativa é o instrumento que permite que haja interação e organização entre os atores na busca de consensos e trocas de saberes sem coação externa, valendo-se apenas de regras internas aos grupos.

A ação comunicativa de Habermas se apóia justamente em relações horizontais de comunicação. São estas as interações que compõem as redes. Todas as definições de governança se referem a algo mais amplo que governo e focam de alguma forma no papel das redes para atingir objetivos comuns (KJAER, 2004). Dada a destacada importância da inclusão da participação social na gestão municipal, torna-se importante compreender que os principais movimentos sociais atuam por meio de redes. Isto acontece principalmente através da internet, ampliando as relações sociais, que podem tanto ser locais, quanto internacionais, ou em qualquer escala intermediária. Esta é uma forma de exercitar o que Habermas denominou "agir comunicativo", que resulta na criação de novos saberes a partir da 
comunicação, gerando inovações socioculturais (GOHN, 2007b). Para Bovaird (2005) o interesse pela governança local por si só aumenta o interesse pelas redes sociais. Existe uma relação muito próxima entre governança, participação e redes sociais e, com o sucesso da campanha para presidência de Barack Obama, que contratou um dos criadores do facebook para assessorá-lo, as redes ganharam ainda mais destaque como elementos poderosos de opinião pública (WILLARD, 2009). Para Castells (2003), as redes são processos de transformação e de dominação na sociedade atual, a qual o autor denomina "sociedade em rede". Embora as redes tenham existido em outras épocas, a tecnologia da informação disponibiliza a "base material" para que ela penetre em toda a sociedade.

As redes dependem de alguns fatores para funcionar: precisam ser auto-organizadas, as organizações que as compõe devem ser interdependentes e é necessário que haja cooperação e solidariedade nas relações intra-redes (Frey, 2007). Governança pode ser definida como "redes inter-organizacionais auto-organizadas caracterizadas pela interdependência, troca de recursos, regras de jogo e significante autonomia com relação ao Estado" (RHODES, 1997 apud BOVAIRD, 2005, p.219); ou "como uma ação conjunta via rede de todos os "stakeholders" em prol do bem da coletividade" (KISSLER; HEIDMANN, 2006, p.483); ou ainda afirmam que governança refere-se a redes de atores auto-governadas e autônomas (STOKER, 1998). A maioria dos autores, porém, utiliza o conceito de rede para qualificar a participação social no processo de governança, focando ou não na construção de políticas públicas (FERNANDES, 2003; FREY, 2007; RAMOS-PINTO, 2006).

Estes dois recursos associados, a organização em redes e a comunicação eletrônica na forma de governo eletrônico, são tecnologias que, segundo Camargo (2003) podem conferir às decisões dos governos a essencial transparência. É fato que estes dois conceitos, governança e redes, não podem ser dissociados, e as redes são entendidas no mínimo como uma 
forma de articulação e cooperação de atores sociais que compõem a governança. Gohn (2007a) ressalta que as redes com um objetivo estratégico produzem articulações e resultados relevantes, desde associações comunitárias, redes temáticas específicas incluindo as redes de governança, que, através da internet, articulam experiências de administração pública. "As redes de atores, que se formam em torno de políticas específicas, podem ser consideradas como tipos antagônicos ao tipo institucional de 'hierarquia"' (FREY, 2000, p.221). Toda esta interação horizontal promove a ação Comunicativa.

Lee (2006) afirma que as inovações institucionais são essenciais para combater o desafio de construir comunidades que podem se auto-governar em diversas escalas. É uma enorme tarefa que apenas se inicia. A governança qualifica o uso da autoridade do Estado. Envolve, portanto, a forma como o poder é exercido, como é a relação entre o Estado e os grupos organizados da sociedade nos processos de tomada de decisão e de monitoramento e implementação das políticas públicas (ANASTACIA; AZEVEDO, 2002). Este processo de gestão partilhada requer novas habilidades do gestor público, uma vez que ele deve saber envolver e articular os diversos atores do processo participativo de tomada de decisão. Vale ressaltar que os resultados esperados da governança são similares aos esperados dos governos tradicionais, o que muda, é a forma de atingi-los (STOKER, 1998).

Como a governança tem a ver com a forma com que a gestão é realizada e seu conceito ainda está muito amplo e pouco preciso, vários autores buscam explicitar quais condições seriam necessárias para a garantia de sua qualidade. Para Frey (2007) é essencial a existência de um ambiente de confiança mútua e um ambiente de cooperação. Fernandes (2003) coloca como necessário que exista desenvolvimento institucional somado à capacitação de todas as partes envolvidas e incentivo ao envolvimento de lideranças autênticas e à sua livre expressão. Quando fala 
de capacitação, ela afirma ser necessário o investimento em qualificação, tanto dos administradores e técnicos locais, como do setor privado, das ONGs, comunidade organizada ou não, setor privado ou das cooperativas, ou seja, de todos os atores envolvidos no processo.

O que tem sido denominado como governança são todas as estratégias de coordenação dos atores sociais na construção de políticas (IVO, 2002). Frey (2007) distingue duas correntes no que diz respeito à definição de governança. A primeira enfatiza o potencial democrático das novas abordagens de gestão conjunta, enquanto a outra, o aumento da eficiência e efetividade do Estado. Em seu artigo ele conclui que, nos três casos analisados (Porto Alegre, Santos e Curitiba), as ações públicas buscaram trazer efetividade e eficiência de resultados além de participação. O autor afirma ainda que o novo pragmatismo da gestão urbana busca associar a participação dos diversos atores com gerenciamento efetivo. Outra definição, que inclui, tanto a forma, quanto o resultado da gestão, trata a governança como as formas de interação dos atores entre si para influenciar positivamente os resultados das políticas públicas (BOVAIRD; LOFFLER, 2003). "Governança é o processo através do qual, sociedades e instituições tomam suas decisões importantes, determinam quem estará envolvido nestas decisões e como prestarão contas" (WILLARD, 2009).

Para Ckagnazaroff (2009), a governança local no Brasil "trabalha principalmente com aspectos voltados para a inclusão social e a democratização, onde se reconhece, também, a importância da coordenação". O autor não inclui a eficiência e efetividade do Estado nesta abordagem, o que pode indicar uma negligência destes aspectos. Santos Junior também ressalta este enfoque, quando afirma que o sentido da governança mais freqüente é "[...] como a interação entre governo e sociedade, com análises centradas na questão dos arranjos institucionais que coordenam e regulam a relação entre governo e os atores sociais dentro de um sistema político". Assim, o foco de análise recai nas "relações de 
cooperação e conflito entre as diversas categorias de atores" na gestão municipal (SANTOS JUNIOR, 2001, p. 60). É preciso cuidado para não imaginar, primeiro, que todos os conflitos necessariamente resultem em acordo, pois alguns podem não ser negociáveis, e segundo, não imaginar que todos os atores têm recursos suficientes para participar das negociações. Ainda para Santos Junior (2001), torna-se necessário construir indicadores capazes de avaliar o desempenho governamental para que possam ser analisadas as boas práticas de gestão municipal. $\mathrm{O}$ autor não mostra a necessidade de incluir indicadores de resultados que possam indicar a citada eficiência e efetividade da ação pública.

Foi o Banco Mundial que deu impulso a estas reflexões na busca de condições que, no contexto da década de 1980 poderiam garantir um Estado eficiente. Nesta abordagem, desloca-se a atenção estritamente econômica da ação do Estado para o envolvimento das questões sociais e políticas da gestão pública. Para que as agências multilaterais forneçam crédito aos governos, é necessário que este passe pelo "teste da democracia", com índices razoáveis de respeito aos direitos humanos, aos padrões ecológicos, à transparência democrática e à coalizão entre os atores sociais, que, segundo Gohn (2007a), são ingredientes da boa governança. "Desde as origens do conceito de desenvolvimento sustentável no relatório Brundtland, em 1987 ficou clara a necessidade de uma nova abordagem para a governança" (WILLARD, 2009) e as tecnologias da comunicação têm auxiliado nesta nova abordagem, uma vez que promovem o engajamento dos atores de diversos setores e instituições, seja através da comunicação móvel, da mídia social ou das redes sociais "on-line"(WILLARD, 2009).

Para Kjaer (2004), o Banco Mundial está relacionado com a governança de três formas. Em primeiro lugar, a boa governança é uma condição para o banco ceder empréstimos para os países pobres, uma vez que no século XXI, deixou de financiar programas para melhorar a governança e passou a requerer a boa governança como condição para 
ceder financiamentos. Segundo, o banco utiliza os preceitos de boa governança internamente, melhorando a prestação de contas perante seus Estados membros. Por fim, o Banco Mundial é um caso de relevância quando o assunto é boa governança.

Para Frey (2008), entretanto, o Banco Mundial está sujeito à vontade da comunidade internacional para o desenvolvimento e, como conseqüência, pela lógica neo-liberal ${ }^{21}$. Mesmo o conceito de boa governança do Banco Mundial tendo sido dirigido aos governos nacionais, os municípios têm suas práticas políticas influenciadas pelo contexto social e político de seus países, e adotam os mesmos princípios. Discute-se se os conceitos do Banco Mundial sobre empoderamento, participação e capital social não buscam aumentar a capacidade das populações excluídas de se auto-ajudar e assumir a responsabilidade por si.

Para Maricato (2000, p.131) "a crescente importância da autonomia das cidades [...] chega a evocar o retorno das "Cidades-Estado". A Agenda Habitat II $^{22,}$ assim como a Organização de Cooperação para o Desenvolvimento Econômico $(\mathrm{OCDE})^{23}$ e o Banco Mundial atribuíram às cidades grande importância no cenário mundial, pregando a descentralização e a afirmação do poder local, as parcerias e a auto-gestão dos serviços coletivos, velhas reivindicações de movimentos de esquerda, movimentos populares e ONGs (MARICATO, 2000).

A governança não é uma fórmula de sucesso. É na verdade um processo de gestão que inclui a experimentação, diálogo, debate e

21 "A famosa cartilha do "Consenso de Washigton", elaborada num seminário realizado entre 14 e 16 de janeiro de 1993, sob a orientação de Fred Bergsten, em um destacado think tank de Washington, o Institute for International Economics, estabelece literalmente dez pontos a serem seguidos pelos países interessados nesse "modelo" de adesão ao capitalismo global, que inclui, entre outros, pontos tão didáticos e sintéticos quanto "as empresas estatais deverão ser privatizadas" (FERREIRA, 2003, p. 138). Os dez

22 Esta agenda foi criada na conferência da ONU para os Assentamentos Humanos em 1996, em Istambul.

23 É uma organização que envolve os Estados mais ricos do mundo. 
conflito e a busca de consenso. Isto pode estar na raiz do enfoque que é dado à forma da governança sobre os resultados que produz. A governança municipal pode ser entendida como o processo de gestão em que a prefeitura inclui e estimula a participação social com o objetivo de produzir políticas públicas que: conduzam ao desenvolvimento sustentável; estejam alinhadas às necessidades e prioridades de seus cidadãos; e produzam resultados efetivos; evitando-se a utilização do poder de coerção próprio do Estado.

\subsection{POLÍTICAS PÚBLICAS}

Com este novo ambiente, onde a governança responde à diminuição do poder do Estado utilizando instrumentos que abrem espaço para a participação cidadã na gestão pública e dada a importância dos governos municipais na melhoria da qualidade de vida dos cidadãos e na busca do desenvolvimento sustentável, torna-se necessário compreender como a ação governamental se concretiza. Isto acontece através das políticas públicas.

Segundo Philippi Jr. e Bruna (2004, p. 691) política pública é "o conjunto de diretrizes estabelecido pela sociedade, por meio de sua representação política, em forma de lei, visando à melhoria das condições de vida dessa sociedade".

Souza (2006), em seu artigo teórico sobre políticas públicas considera que a definição mais conhecida seja a de Laswell, onde é essencial responder quem ganha o quê e por quê para as decisões e análises sobre políticas públicas. Mas a autora apresenta outras definições como a de Dye (1984 apud SOUZA, 2006) que afirma que política pública pode ser definida como "o que o governo escolhe fazer ou não fazer", ou a de Peters (1986 
apud SOUZA, 2006) que diz que política pública é composta pelas atividades dos governos que influenciam a vida dos cidadãos, sejam elas diretas ou delegadas. Nesta mesma linha, Guerra (2006) define política pública como um sistema de cooperação em matéria de ação pública.

Alguns críticos vêm estas definições como muito técnicas, desprezando o ambiente político no qual essas idéias são geradas. Além disso, estas definições concentram sua atenção no governo, excluindo as interações, cooperações que acontecem no processo. Apesar destas críticas, nas diversas definições de políticas públicas tem-se em mente que o todo é mais importante que a soma das partes. A ideologia, as instituições, os interesses, os indivíduos e as interações são considerados pelos diversos autores, embora a importância que cada um dá a cada elemento varie. Como as políticas públicas têm forte impacto na economia e na sociedade, é importante que expressem as relações entre estado e a sociedade afetada (SOUZA, 2006).

Quando o governo assume que deve fazer algo sobre um problema ou quando uma demanda interessa eleitoralmente, ela entra na agenda política. Para chamar a atenção do governo para uma dada questão, é necessário que exista pressão popular ou que se tenha indicadores claros apontando para a necessidade de intervenção ou para o descaso da administração sobre $o$ assunto.

Essas considerações apontam para, os principais elementos das políticas públicas reorganizados a partir de Souza (2006, p.37). A política pública é abrangente e não se limita a leis e regras; é uma ação intencional, com objetivos a serem alcançados; permite distinguir entre o que o governo pretende fazer e o que, de fato, faz; embora tenha impactos no curto prazo, é uma política de longo prazo; envolve vários atores e níveis de decisão, embora seja materializada através dos governos, e não necessariamente se restringe a participantes formais, já que os informais são também 
importantes; e envolve processos subseqüentes após sua decisão e proposição, ou seja, implica também implementação, execução e avaliação.

As políticas públicas são fundamentalmente escolhas feitas pelas instâncias de decisão, que se quer participativas. Se os recursos naturais são escassos, trata-se além de economizá-los de questionar se serão utilizados para produzir alimentos ou guerras, como expressou Acselrad (2009) de forma dicotômica. A ideologia, os valores e as idéias assumem papel importantíssimo neste processo, e, o sistema de formulação de políticas públicas se divide em coalizões que se diferem justamente por estes atributos (SOUZA, 2006). Para Acselrad (2009) a questão da sustentabilidade é uma questão política de se determinar quem ganha e quem perde nos processos de mudança sociológica, logo, torna-se necessário estar atento para a diferenciação social quando as transformações ambientais favorecem um grupo social em detrimento de outro. Os problemas sócio-ambientais não dependem apenas do alcance do crescimento econômico, nem somente de um planejamento eficiente orientado pelos limites ambientais, mas principalmente da superação de conflitos e justiça social. Frey (2001, p.14) afirma que a solução para estes entraves é uma "questão eminentemente política". Prejudica-se "quem tem menor capacidade de influenciar o Estado e rejeitar a localização de práticas espaciais portadoras de risco em suas proximidades" (ACSELRAD, 2009). Durante o período de autoritarismo no Brasil houve um projeto de modernização que impulsionou a industrialização e a urbanização. Nesta época foram tomadas as principais decisões que levaram à realocação da população de baixa renda na periferia, que são áreas com pouca infraestrutura de transporte, educação, saneamento e saúde (AVRITZER, 2002). Estas são algumas das questões que a sustentabilidade urbana tem como desafio neste século XXI. Costa (1999, p.62) se reporta a uma busca por uma nova ética e pelo retorno de uma vida social mais solidária e democrática. As propostas devem resistir ao crivo da "assimetria das relações 
de poder, ou a quase impossibilidade de uma solidariedade capitalista". A gestão urbana é formada de processos complexos que sofrem a influência da grande variedade de atores sobre as suas estratégias de coordenação, ajustes e consensos (CHEVALIER, 1998).

"Apesar da comunidade internacional se reportar unanimemente favorável à concepção de desenvolvimento sustentável, dificilmente consegue-se reconhecer esse suposto compromisso com a defesa do meio ambiente e das gerações futuras nas ações atuais" (FREY, 2001, p.1). O autor afirma que houve vários frutos do debate sobre sustentabilidade, como investimento em ciência e pesquisa ambiental, a estabilização dos movimentos ambientais transnacionais e a criação de arranjos institucionais assim como negociações e fóruns de debate, mas a criação de políticas públicas em todos os níveis de governo tem-se mostrado incapazes de traduzir as demandas ambientais.

Cada vez mais a legislação dos diversos países encoraja a formulação de políticas através de processos participativos. Além do arcabouço legal, vários partidos utilizam propostas participativas para se diferenciar dos demais, e, quando assumem governos, criam instrumentos de participação. Os conselhos setoriais e o orçamento participativo são duas formas de participação brasileiras que surgiram deste processo (PINHO; SANTANA, 1998). Como a sustentabilidade e as políticas públicas são resultado de escolhas, trazer a população afetada e interessada para as instâncias de decisão parece ser um caminho promissor.

Faria (2003) aponta o alargamento da gama de atores que participam do processo de formulação de políticas públicas. O que inicialmente era realizado por: a) políticos; b) burocratas; e c) grupos de interesse, neste novo cenário amplia somando-se ainda: d) mercados financeiros; e e) atores não governamentais, que aqui são entendidos como sociedade civil em suas diversas formas de organização. 
Nos trabalhos brasileiros e na maioria dos trabalhos internacionais atuais sobre políticas públicas locais fica evidente a necessidade de mobilizar diversos atores da sociedade civil e incluir as redes. BOURDIN (2001) afirma que isto não é uma tradição da ação pública francesa. Por outro lado, existe a prática de consulta à população por ocasião de projetos novos, embora com resultados aquém do esperado. Além disso, segundo PHILIPPI JR. BRUNA (2004) é necessário que exista uma gestão integrada das políticas.

A ênfase dos estudos sobre políticas públicas recai sobre 0 processo de formulação, e não no processo de avaliação destas políticas. Isto ocorre, talvez, pelo status do processo decisório junto aos pesquisadores (FARIA, 2003). A avaliação de políticas aborda dois processos importantes. 0 primeiro diz respeito à tomada de decisão, o que envolve valores e disputas políticas. Este é mais complicado de ser avaliado, uma vez que inclui a verificação de resultados segundo um escala de valores. O outro enfoca o resultado da política através do resultado dos planos, programas e projetos que a compõem, o que pode ser feito através de dados e indicadores, sendo mais pragmático e mensurável. Busca-se construir modelos de formulação de políticas que, em sua concepção, incluam formas de aferição de resultados, como, por exemplo, indicadores. Então, para avaliar políticas públicas é necessário gerar estes indicadores tanto qualitativos quanto quantitativos que permitam verificar em que grau o resultado das políticas foram alcançados, assim como a qualidade do processo de tomada de decisão. Para tanto, pode-se definir o objetivo geral de uma política e dividi-lo em objetivos específicos com metas mensuráveis por estes indicadores (ALVIM et al., 2007). É necessário que se faça a ressalva colocada por Foladori (1999), pois os indicadores medem majoritariamente as questões técnicas, principalmente porque são resultados de estudos disciplinares em uma área interdisciplinar, não conseguindo captar com eficiência a diversidade das sociedades. Apreendem apenas as questões da sociedade como um bloco face o meio 
ambiente e é preciso estar atento para captar as diferenças internas de uma sociedade para respaldar as questões relacionadas à eqüidade (FOLADORI, 1999).

Além das análises de políticas públicas baseadas na forma como a política é instituída, o que inclui as forças políticas atuantes no processo de tomada de decisão ("Politics Analysis") e dos resultados alcançados pela dada política ("Policy Analysis") Frey (2000) apresenta a "Polity Analysis" que trata das instituições políticas e da estrutura institucional em que determinada política é constituída.

Esta tese se identifica com a análise das políticas públicas com base na forma com é instituída, embora se considere que os resultados destas políticas sejam igualmente importantes. Porém ao se pensar que prejudica-se quem tem menor capacidade de influenciar o Estado, incluir nos processos de tomada de decisão a sociedade civil como um todo torna-se também uma ferramenta de justiça social. Se um grupo tem influência no processo de formulação de políticas públicas, faz pressão e fiscaliza a ação do governo, passa a ser co-autor de seus resultados, caso a política seja implementada de forma eficiente e efetiva.

\subsection{PARTICIPAÇÃO}

A participação da sociedade civil nos processos de formulação e implementação de políticas públicas acontece no Brasil há duas décadas e ainda é um processo em construção. Até a década de 1980, a pouca participação existente era formada por movimentos sociais ${ }^{24}$

${ }^{24}$ Movimentos sociais são "ações sociais coletivas de caráter sócio-político e cultural que viabilizam distintas formas da população se organizar e expressar suas demandas" variam da simples denúncia à pressão direta ou indireta. As redes sociais são novas formas de 
reivindicativos como associações de bairros ou demandas por serviços de saúde, com objetivos específicos e negociáveis, tais como: creches, escolas, postos de saúde, urbanização de favelas. Estes movimentos buscavam bens coletivos de natureza negociável, e não questionavam princípios e valores (ANASTACIA; AZEVEDO, 2002). No final daquela década, os movimentos populares, que já eram mais freqüentes e visavam a ampliação dos canais de acesso do cidadão ao processo de tomada de decisão, moldaram o ambiente em que se formaram as assembléias constituintes dos três níveis de governo: a constituição brasileira (1986-1988); as constituições estaduais (1988-1989); e as leis orgânicas municipais (1989-1990) (CALDERÓN; MARIN, 2002). Nestas leis, e em políticas setoriais dos três níveis de governo, foram instituídos os conselhos setoriais, com funcionamento razoavelmente uniforme, mas com grau de organização e independência bem variável. Com o anseio da sociedade em participar diretamente da gestão, o modelo de democracia representativa deixou de atender as necessidades da população. A participação pública na tomada de decisão passou, então, a constar no ordenamento jurídico de alguns países de diversas formas (FURRIELA, 2002) ${ }^{25}$.

Esta nova forma de associativismo é mais propositiva e menos reivindicativa tendo um caráter mais estratégico, tornando as grandes manifestações mais raras. A "Participação Cidadã" é o conceito que suporta estas novas ações e a noção de cidadania foi ampliada para além do direito

movimentos sociais e a internet é seu principal instrumento. É o exercício do agir comunicativo de Habermas. "são fontes criadoras de criatividade e inovações socioculturais [...] expressam energias de resistência ao velho que os oprime, e fontes revitalizadas para a construção do novo". Não são necessariamente bons. Existem os movimentos sociais conservadores, xenofóbicos, religiosos e raciais, que incitam a intolerância e terrorismo. "Os movimentos sociais progressistas atuam segundo uma agenda emancipatória, realizam diagnósticos sobre a realidade social e constroem propostas" (GOHN, 2007).

25 Ou como experiências de gestão, como as Cidade Californianas, onde a forma de atuação do movimento das cidades sustentáveis, descrito por Costa (1999) expressa o conceito de Razão Comunicativa de Habermas e está mais próximo dos conselhos instituídos no Brasil, uma vez que o poder público e a sociedade civil organizada discutem seus saberes e constroem um consenso. 
ao voto, com o objetivo de fortalecer a sociedade civil, para criar caminhos para uma nova realidade social. Cidadania está associada a direitos e deveres (GOHN, 2007a).

A Habitat 2 afirma que, para solucionar os problemas urbanos é necessário encorajar o diálogo entre os diversos atores, sejam ONGs, setor privado ou o setor público, pois, dada a magnitude dos problemas dos assentamentos humanos, a sociedade deve usufruir do conhecimento e das capacidades de cada cidadão (UN HABITAT, 1996). ALVA (1997) afirma ainda que, para que esses problemas sejam enfrentados, é necessário que se tenha, além dos mecanismos de participação, uma visão mais holística, que pode ser representada pelo desenvolvimento sustentável.

A redefinição da noção de cidadania ocorrida na década de 80 auxilia na promoção de uma sociedade que reconhece seus membros como "sujeitos portadores de direitos", o que inclui o direito de participar na gestão da sociedade. Como conseqüência, surgiram os espaços públicos que têm como objetivo promover um amplo debate na sociedade civil, e conseqüentemente, incluir temas e interesses que estavam fora da agenda política. Como exemplos destes espaços de democratização da gestão estatal têm-se conselhos, fóruns, câmaras setoriais e OPs (DAGNINO, 2002).

Santos Jr. (2001) se apóia no trabalho de Dahl (1997, apud SANTOS JUNIOR, 2001) e afirma que a responsividade contínua de um governo às preferências dos seus cidadãos é a característica chave da democracia, desde que os cidadãos sejam todos considerados politicamente iguais, sendo capazes de formular e expressar suas preferências e de seus concidadãos ao governo, tanto através de ação individual, quanto de coletiva e de ter suas preferências consideradas pelo governo, sem discriminação do conteúdo ou da fonte. Existem oito condições necessárias para que a democracia seja mantida: "'(i) liberdade de formar ou aderir a organizações; (ii) liberdade de expressão; (iii) direito de voto; (iv) elegibilidade para cargos 
públicos; (v) direito de líderes políticos disputarem apoio e votos; (vi) fontes alternativas de informação; (vii) eleições livre e idôneas; (viii) instituições para tornar as políticas governamentais dependentes de eleições e de outras manifestações de preferência"' (DAHL 1997 apud SANTOS JUNIOR, 2001, p.70). $O$ autor ressalta ainda que estas condições institucionais têm variado de amplitude e forma nos diversos regimes, tanto ao longo do tempo, quanto na atualidade.

Para que a democracia seja efetiva, devem ser incorporados outros níveis de poder além do Estado. Levy (1997), baseada em Held (1987, apud Levy) descreve as características da democracia representativa: a participação direta dos cidadãos na regulação das instituições chave da sociedade, incluindo o local de trabalho e a comunidade; reorganização dos partidos políticos, tornando seus membros representantes diretamente controlados pelos membros inscritos; ação de 'partidos participativos' em parlamentos e congressos; manutenção de um sistema institucional aberto para assegurar a possibilidade de experimentação de formas políticas (LEVY, 1997, p.48). "Igualdade de votos; participação efetiva; compreensão qualificada das matérias debatidas; controle financeiro da agenda pelo "demos"; incorporação de todos os cidadãos no processo" seriam condições para a democracia ser exercida (LEVY, 1997, p.50).

No Brasil, por um lado, a assembléia constituinte ocorreu sob o controle de "atores políticos ligados ao regime autoritário" (AVRITZER, 1998; MARTINS, 1987 apud AVRITZER, 2002, p.18). Por outro, houve um "vigoroso" processo de democratização a partir da década de 80 com um rearranjo nas estruturas políticas, que foi campo fértil para a entrada de novos atores na cena política gerando transformações (TONELLA, 2006). Como conseqüência, questões como a reforma agrária ou a forma do sistema político não foram resolvidas pela Carta Magna, mas houve abertura de espaços para um conjunto de políticas participativas inovadoras, como o OP e os conselhos setoriais (AVRITZER, 2002). Tonella (2006) aponta a 
democracia como a arena para que não aconteçam rupturas definitivas. Um regime democrático é a única forma de garantir a possibilidade de participação e de renovação da forma de fazer política.

A participação dos cidadãos é uma forma diferenciada de democracia representativa (JACOBI, 2002). Gohn (2007a) chama de democracia deliberativa esta associação entre a democracia direta e a democracia representativa, proporcionada pelos conselhos.

Houve uma mudança no cenário da participação no final no século XX. Dois fatores contribuíram para isto. O primeiro foi a existência prévia de mobilização popular, através dos movimentos sociais, e o segundo foi a inserção da participação na agenda política o que permitiu que novos espaços públicos não estatais se instalassem. A sociedade civil organizada torna-se parceira permanente da participação cidadã e esta passa a ser concebida como uma intervenção social periódica e planejada ao longo do circuito de formulação e implementação de uma política pública. Mas, para que a participação cidadã ocorra de fato, é necessário que os sujeitos de uma comunidade estejam organizados e mobilizados articulando suas idéias (GOHN, 2007a). Em algumas camadas sociais, porém, a associação é motivada pela exclusão social e é vista como forma de conseguir melhora na qualidade de vida. Neste contexto surge a solidariedade e o sentimento de "pertencer", unindo-se esforços para se obter os resultados almejados (TEIXEIRA, 2005).

A participação pode acontecer segundo três níveis de profundidade: quando há apenas consulta; quando muitas pessoas participam, mas apenas algumas têm poder de decisão; e quando todos os participantes deliberam (GOHN, 2007a). Este é, entretanto, o único caminho para que uma sociedade seja democrática, seja com a participação de seus cidadãos de forma individual ou representando organizações da sociedade civil. Ressalta-se que é no plano local onde se concentram as forças sociais 
da comunidade e que é gerada a coesão social, a solidariedade e as forças emancipatórias para a mudança; e o poder de uma comunidade não existe se não for organizado, aglutinado em função de objetivos legítimos que criem laços de identidade sócio-cultural e política (GHON, 2004). Os conselhos gestores e o orçamento participativo são a expressão da mobilização da população em torno da participação em estruturas políticoadministrativas da cidade, e compõem um dos 10 eixos temáticos das lutas e demandas dos movimentos sociais no Brasil identificados por Gohn (2007b).

A literatura sobre governança, em particular a recente versão francesa, desenvolveu três grandes idéias: a sociedade civil, que permeia as relações entre a esfera política propriamente dita e a sociedade; as parcerias entre o setor publico e o setor privado; e na construção de percepções, conhecimentos e crenças comuns, o que não implica numa coalizão de interesses mas num trabalho comum que não exclui jogos de oposição (BOURDIN, 1998). Para Boudin (2001) a mobilização e a organização dos saberes são condições para a implementação de políticas públicas verdadeiras, mas a grande quantidade de atores, suas características individuais e a diversidade de interesses tornam a mobilização mais penosa.

Um aspecto importante é que não é qualquer participação que interessa para a boa governança. A governança pressupõe participação social buscando atingir três objetivos: desenvolver uma agenda de objetivos comuns com a sociedade, promover a gestão compartilhada dos problemas municipais e, como consequêencia possibilitar o controle social das ações governamentais. A sociedade deve ser capaz de garantir espaços onde se discutam as políticas públicas, os recursos públicos e as estratégias de ação do Estado (BAVA, 2005), e assim garantir a inserção dos diversos grupos de interesse no processo (SOUZA, 2006). Os espaços existentes para esta discussão no Brasil - os conselhos gestores - estão juridicamente definidos e garantem caráter legal às suas deliberações. A participação, que vai além da busca da sociedade por mais espaço no processo decisório, é a forma mais 
direta de se trabalhar com objetivos comuns e partilhados entre governo e sociedade. Como nenhum dos atores envolvidos em processos de gestão de problemas locais tem sozinho o conhecimento e os recursos para resolvê-los, a interação entre atores é positiva. Este potencial de ação sobre as carências locais é maior se os atores envolvidos forem locais ou regionais, em detrimento de atores estaduais ou nacionais (KISSLER; HEIDEMANN, 2006).

As idéias surgidas de processos participativos podem funcionar como mapas, pois ninguém mais que o cidadão sabe suas preferências na hora de aplicar o dinheiro público. Para que isto aconteça, a participação deve ocorrer de maneira que se obtenham as vantagens do conhecimento do sítio, decisões legítimas e monitoramento pela sociedade. As autoridades devem assumir o papel de mobilizadores dos atores sociais relevantes e representativos. A associação entre o poder público e a sociedade soma valor às decisões. Os funcionários das prefeituras contribuem apresentando caráter técnico, trazendo o entendimento, os dados e o realismo, enquanto os demais atores, sejam eles sociedade civil organizada, cidadãos, empresários ou militantes, fornecendo as demandas, as prioridades e a diversidade. Na verdade, a solução dos problemas não deve depender exclusivamente de administradores que não os sentem. $\mathrm{A}$ população conhece as demandas porque as enfrenta em seu dia a dia. Se ela participa da tomada de decisão, se sente um pouco dona do projeto, fiscaliza e cuida, conversa com os vizinhos e pode se organizar em torno das soluções (DOWBOR, 1993). Para Burton (2009) o engajamento da comunidade leva a decisões e implementações melhores. $O$ autor afirma que o envolvimento comunitário agrega valor à decisão pública. Cabe saber se os representantes da população estão preparados para participar. "[...] o discurso da participação, portanto, lança exigências e busca articular a democratização do processo com a eficácia dos resultados - onde a primeira aparece como condição realizadora da segunda" (TATAGIBA, 2002, p.47). 
Quanto mais desenvolvidos os sistemas de participação cívica, maior é a chance de que os cidadãos sejam capazes de cooperar em benefício mútuo. Eles são uma forma importante de capital social. Isto acontece por quatro motivos (PUTNAM, 2006, 183): "os sistemas de participação cívica aumentam os custos potenciais para o transgressor em qualquer transação individual"; promovem regras de reciprocidade que são reforçadas pela cadeia de relacionamentos; "facilitam a comunicação e melhoram o fluxo de informações sobre a confiabilidade dos indivíduos"; incorporam os êxitos alcançados em colaborações anteriores e criam modelos para as futuras colaborações. Numa comunidade cívica a cidadania se caracteriza pela participação nos negócios públicos. Isto implica em direitos e deveres iguais para todos os cidadãos, ou seja, em igualdade política. Ela se mantém coesa por relações "horizontais de reciprocidade e cooperação". Os cidadãos "virtuosos" da comunidade cívica regem suas ações por valores como a solidariedade, a confiança e a justiça. Por fim, forma uma rede de associações e estruturas sociais de cooperação (PUTNAM, 2006, p.100-104). Isto reitera o valor da ação comunicativa descrita por Habermas (2009).

Thomas Jefferson $(1743$ - 1826) dizia que o depósito de poder da sociedade está no próprio povo e, ao se constatar que a população não está esclarecida o suficiente para exercer seu controle com todo o seu discernimento, a solução passa a ser: informar através da educação (BURTON, 2009). A contribuição da educação é necessária tanto para capacitar a população quanto os técnicos do poder público para a tomada de decisão, não só pelo conhecimento local indispensável na hora de definir prioridades ou soluções alternativas, como também para o arcabouço teórico sobre desenvolvimento urbano ou desenvolvimento sustentável, por exemplo, que deve permear todas as decisões. A capacitação é um instrumento indispensável para a qualidade da governança, tanto na tomada de decisão quanto na obtenção dos resultados, quando da execução da 
decisão tomada ${ }^{26}$. Além da capacitação, a informação qualificada e disseminada faz parte das condições para a governança e esta informação tem que ser adaptada aos diferentes públicos-alvo.

A participação é um processo que tem a educação como premissa e como resultado. Na outra via, tem-se o processo educativo no retorno. A participação também exerce um processo educativo valioso sobre o cidadão: melhora a auto-estima, torna o indivíduo confiante em sua capacidade de controlar outros aspectos de sua vida, faz com que ele pense em seus interesses, cria condições para expressar aspectos de sua identidade, tais como ser ecologista e, por fim, torna o cidadão mais sociável contribuindo para a coesão social (BURTON, 2009). Para Gohn (2007a, p.43), a principal função da participação deve ser o caráter educativo que exerce sobre as pessoas, "à medida que fornecem informações, os capacitam para a tomada de decisão e desenvolvem uma sabedoria política, [...] contribuem para o desenvolvimento de competências e habilidades a partir das experiências que vivenciam".

[...] a própria sociedade precisa ser democratizada e assumir uma cultura de participação e também uma ética de responsabilidade pública. Os conselhos poderão contribuir para isso exigindo que os representantes sejam eleitos em assembléias das entidades ou de fóruns mais amplos e que haja espaços de interlocução em que o cidadão nãoorganizado possa participar (TEIXEIRA, 2000, p. 108).

Os processos educativos e a sensação de pertencimento proporcionados pela participação social contribuem para que o cidadão, agora fortalecido, utilize os canais participativos para a formulação de políticas públicas e o monitoramento da sua implementação, que são

26 Pode-se exemplificar este aspecto apresentando uma experiência mexicana de gestão de bacia hidrográfica, o que requer a cooperação de prefeitos de cidades vizinhas, nem sempre alinhados politicamente, onde foi a Universidade de Guadalajara preparou uma capacitação através da programação de uma visita a dois casos de sucesso, um no Canadá e outro nos Estados Unidos. Mesmo com os curtos mandatos de 3 anos para 0 executivo municipal, estas visitas têm conseguido motivar os prefeitos e o projeto tem sido mantido ao longo das gestões (MONTERO et al, 2006). 
essenciais para alcançar a boa governança visando o desenvolvimento sustentável (MONTERO et al., 2006). Participação digna necessita certas condições, como: o grau correto de politização; um compromisso e um envolvimento sério; o reconhecimento da dignidade de todos os participantes; e procedimentos que garantam que tanto a participação em si, quanto quaisquer resultados alcançados sejam reais e eficazes (BÜHLER, 2002). Desta forma, a participação assume o papel de agente promotor da boa governança.

A legitimidade do governo pode ser instituída tanto orientada pela entrada, "input oriented", quanto orientada pela saída, "output oriented", ou ainda, o que é mais comum, por uma combinação das duas em diferentes graus de participação. Quando é orientada pela entrada, a legitimidade decorre de acordos entre os cidadãos, que devem obedecer as regras geradas. Desta forma, ela se estabelece através de procedimentos democráticos que são aceitos pela maioria. Quando é orientada pela saída, a legitimidade deriva dos resultados das políticas públicas, que devem ter o bem comum como objetivo (KJAER, 2004). Esta forma de entender a legitimidade pode ser ligada com o conceito de governança apresentado, onde a "input oriented" está relacionada com a forma participativa e inclusiva da governança e a "output oriented" com a eficiência e efetividade do Estado.

Mesmo com a inclusão dos processos participativos na Constituição Federal brasileira, duas ressalvas devem ser feitas. Em primeiro lugar, deve-se considerar que a adesão à participação da sociedade civil, com a predisposição à negociação e o estabelecimento de ações conjuntas entre poder público e cidadãos não acontece de maneira uniforme nas diversas instâncias de governo e localidades (DAGNINO, 2002). Em segundo,

Os desafios para ampliar a participação estão intrinsecamente vinculados à predisposição dos governos locais de criar espaços públicos e plurais de articulação e 
participação, nos quais os conflitos se tornam visíveis e as diferenças se confrontam, como base constitutiva da legitimidade dos diversos interesses em jogo (JACOBI, 2002, p.452).

A sociedade deve garantir espaços para poder discutir suas necessidades. Alguns destes espaços estão institucionalizados, como os conselhos e o OP. Entretanto, estes espaços devem permear a sociedade, ser também não institucionais e até virtuais. Assim, como o indivíduo sozinho não carrega todo o conhecimento, a sociedade civil age de forma comunicativa, cria consensos, se aparelha e troca conceitos. Faz parte de um processo educativo que se soma à educação formal e cria condições de se organizar para poder participar, colaborar, pressionar e criar consensos com o poder público.

\subsection{GESTÃO LOCAL}

Para que haja instituições governamentais eficazes nas localidades, é necessário que haja mudanças do governo do estado e do país. Mesmo assim, o governo local costuma ser mais eficaz e importante na vida da maioria das pessoas que o nacional. Além disso, não é possível que os governos nacionais e as agências internacionais cumpram suas responsabilidades globais sem eficácia de instituições governamentais locais como parceiras (SATTERTHWAITE, 2005). Os governos municipais sofreram mudanças na arena decisória: uma progressiva municipalização e descentralização das políticas públicas; mecanismos de democracia deliberativa foram instituídos; a criação de um "welfare" municipal com a instituição de um "sistema político redistributivo de renda, serviços e bens públicos" (SANTOS JUNIOR, 2001). 
Tanto governos social-democratas, quanto conservadores utilizam a idéia de descentralização transformando-a em consenso internacional. Na América Latina, e nos demais países em processo de redemocratização a transferência de poderes para o governo, entidade ou órgãos locais passou a ser entendida como essencial para a superação do autoritarismo anterior. Mesmo assim pode-se vislumbrar duas vertentes. Os governos tradicionais almejam a descentralização como forma de modernização gerencial da gestão pública, enquanto os social-democratas vislumbram a possibilidade de aproximar o governo dos cidadãos, tornando-o mais acessível e aumentando a participação, o controle e a responsabilização social (ROLNIK; SOMEKH, 2001).

Os espaços públicos locais podem ser definidos como "os múltiplos processos de concertação e os engajamentos mútuos de parceiros de direito público e privado, tais como grupos de habitantes, organismos profissionais, ONGs, empresas e órgãos de administração pública municipais, estaduais e federais" (AVRITZER; PEREIRA, 2005, p.20). É através destes espaços que as práticas de gestão das políticas públicas se desenvolvem nos municípios. O desafio é aumentar os níveis de participação democrática dos cidadãos e, ao mesmo tempo, aumentar a eficiência da máquina burocrática estatal. Os municípios receberam novas competências que alteraram o funcionamento das instituições públicas e as características dos profissionais necessários para dar conta destas mudanças (AVRITZER; PEREIRA, 2005).

Poder local é um conceito mais abrangente que governo local, principalmente com estes novos formatos de gestão pública. Além do poder público instituído, o poder local é exercido pelo poder econômico, político e social das famílias e poder carismático de líderes. Inclui-se nele as novas formas de participação e organização popular. Caracteriza-se por ser o espaço de gestão político administrativo e não como simples sede das elites. A governança local busca articular os elementos do governo local com os de 
poder local, que inclui as parcerias, a gestão compartilhada e os diversos atores (GOHN, 2007a).

Alguns autores reconhecem que o município recebe novas demandas e afirmam que a gestão municipal não está preparada para lidar com elas. Vojnovic (s/d), Dowbor (2003) e Camargo (2003) enfatizam a falta de mecanismos para as administrações municipais lidarem com as questões de sustentabilidade das quais ficaram responsáveis. Estes mecanismos estão sendo aprimorados e incluem a participação na gestão pública, que, segundo Gohn (2004, p.24) "não é para substituir o Estado, mas para lutar para que este cumpra o seu dever [...]". É necessário, porém, cuidado, pois o conceito de cidadania, que passou a ser essencial para o de sociedade civil a partir anos 1990, foi incorporado nos discursos oficiais e ganhou novos contornos mais próximos da idéia de participação civil, incluindo os exercícios da civilidade e de responsabilidade social, homogeneizando os atores. Esta alteração pode levar à tentativa de responsabilização dos cidadãos, através de parcerias nas políticas sociais governamentais em arenas políticas.

A participação e a descentralização são, então, processos estratégicos para a caminhada em direção ao desenvolvimento sustentável. A Agenda 21 enfatiza a necessidade de participação para a implementação de estratégias eficazes visando a obtenção do desenvolvimento sustentável, quando fala da necessidade de parcerias com as partes interessadas incluindo os indivíduos. Porém, Camargo (2003) aponta que nos balanços de 10 anos da Rio 92 ficou patente a falta de mecanismos de governança, de forma a fortalecer a capacidade de gestão dos governos no sentido, tanto de aumentar a própria participação, quanto a eficácia dos resultados. Lee (2006) mostra certo ceticismo ao avaliar a Agenda 21. Para o autor, assim como outros instrumentos que pretendem levar ao desenvolvimento sustentável, este procura permitir que, tanto as gerações atuais, quanto as futuras tenham condições de alcançar suas necessidades. De partida, considera que estes passos não levam necessariamente à uma economia 
sustentável, afinal não é obvio que alcançando os objetivos da Agenda 21, que parecem viáveis na economia atual, sejam iniciados esforços para alcançar metas mais difíceis; depois, é inerentemente difícil de especificar quais seriam as necessidades das gerações futuras. "Não é possível articular a meta do desenvolvimento sustentável em termos concretos" (LEE, 2006, p.10).

É necessário que existam estruturas de governança local eficazes e na maioria das pequenas cidades e centros urbanos em países não desenvolvidos, estas não são evidentes. Há muitos fatores que limitam a criação de estruturas de governança adequadas, ou que limitam as suas possíveis ações para resolver os problemas de pobreza ou de degradação ambiental. O despreparo técnico e financeiro torna-se um impeditivo para que os pequenos municípios possam atingir um grau desejável de autonomia (TONELLA, 2006). Boa governança da cidade deve incluir ações para garantir que a infra-estrutura e os serviços urbanos estejam disponíveis para todos dentro de seus limites, assim como transparência na gestão e no uso dos recursos públicos. (SATTERTHWAITE, 2005). A discussão sobre a importância de se fortalecer o poder municipal já estava na pauta da gestão pública no Brasil. Respondendo a esta demanda, a constituição brasileira (1988) contempla esta questão e aumenta as responsabilidades dos municípios brasileiros. Em 2001, a lei federal 10.257 chamada de Estatuto da Cidade (BRASIL, 2001) reitera esta importância e oferece instrumentos para que os municípios brasileiros possam fazer exercer a função social da cidade através da função social da propriedade, de forma a direcionar o desenvolvimento urbano para o desenvolvimento sustentável. Para que se possa potencializar as oportunidades que as cidades oferecem e, paralelamente, minimizar seus impactos, é necessário que os governos locais apoderem-se de instrumentos de gestão adequados, tanto a estas exigências, quanto ao cidadão deste início de século que se torna mais participativo e mais questionador. Segundo Ckagnazaroff (2009), 
recentemente as administrações de algumas capitais procuram conciliar descentralização municipal com orçamento participativo e os conselhos setoriais.

A Constituição de 1988 (BRASIL, 1988) é universalista quanto aos direitos sociais, redistributiva quanto à renda e democrática quanto à gestão pública. (SANTOS JUNIOR, 2001). Nela tem-se: título II "Dos Direitos e Garantias Fundamentais" - discorre sobre os direitos individuais e coletivos, sociais e políticos. Amplia o espaço para que a cidadania seja exercida. A "participação popular, por meio de organizações representativas, na formulação das políticas e no controle das ações em todos os níveis" pertence à Seção da "Assistência Social". Quando aborda os objetivos da Seguridade Social, no artigo 194, o inciso VII assegura o "caráter democrático e descentralizado da gestão administrativa, com a participação da comunidade, em especial de trabalhadores, empresários e aposentados". A partir da Carta Magna, as legislações específicas, as constituições estaduais e as leis orgânicas municipais passaram a incorporar o formato participativo em seus textos (Constituição, baseado em TONELLA, 2006). Na década de 1990, como conseqüência da Constituição, diversas políticas nacionais foram regularizadas e incluíram a idéia de participação da sociedade por meio de conselhos na gestão das políticas (CKAGNAZAROFF, 2009).

Os diversos municípios do país receberam atribuições que muitas vezes são incompatíveis com a estrutura política municipal, principalmente as cidades com pequena população. O governo local para dar conta destas atribuições, tem que capacitar seus funcionários e incluir novos atores. Gerir as novas atribuições e os novos espaços políticos participativos, como os conselhos municipais, pode, no primeiro momento sobrecarregar estas administrações, mas pode se transformar em uma forma de agregar conhecimento e compartilhar o poder, estimulando o crescimento das forças sociais que são visíveis no nível local. Dado que as políticas públicas 
brasileiras, principalmente as numerosas políticas municipais, são cada vez mais geridas por conselhos gestores, tem-se que, o bom funcionamento destas instituições torna-se essencial, tanto para a construção de uma agenda política com objetivos compartilhados com os cidadãos, quanto para a consecução de políticas eficientes e efetivas.

\subsection{CONSELHOS}

Os conselhos surgem, historicamente, sempre em momentos de crise. A origem dos conselhos remonta a três situações. A primeira resulta de organizações revolucionárias, como as histórias: Revolução Francesa (1789); conselhos da Comuna de Paris (1871); os Soviets de Petrogrado (1905); e a Revolução Russa (1917). Na segunda situação os conselhos tornam-se organizações do poder nos locais de trabalho, assumindo a forma de assembléias operárias. Ocorreram principalmente na Europa, como as experiências na Itália (1906), Espanha (final do século XIX e a partir de 1955), Berlim (1953) ou Hungria e Polônia (1956). A terceira surgiu como instância de negociação de demandas dos trabalhadores nos países de capitalismo avançado. Atualmente são instrumentos de descentralização e de participação e assumem formatos diferentes nos diversos países. No Brasil, a origem dos conselhos foi em experiências informais realizadas por movimentos sociais ${ }^{27}$, ou como estratégias de luta operária em fábricas, como respostas à inércia dos sindicatos (TEIXEIRA, 2000).

A década de 1990 caracterizou-se pelo envolvimento de atores e forças sociais na criação dos novos formatos de gestão de políticas

\footnotetext{
27 O autor usa como exemplo o Movimento de Saúde da zona leste de São Paulo, cujos membros foram eleitos diretamente pela população e o conselho acabou sendo reconhecido pela Secretaria Estadual de Saúde.
} 
públicas, por um lado, e, por outro, uma crise no setor público e o agravamento dos problemas sociais. Como resultado tem-se o questionamento do padrão de poder autoritário e excludente, e, ao mesmo tempo, a capacidade do Estado de atender às demandas sociais (TATAGIBA, 2002). É neste cenário que os conselhos proliferaram no Brasil. Surgiram como conseqüência da diminuição do poder do Estado e do aumento da influência das organizações da sociedade civil ocupando a lacuna de poder. Para Teixeira (2005, p.90) contribui para isto "o desgaste dos partidos políticos e a ineficácia da representação parlamentar face à centralização do poder no Executivo". A Constituição Federal de 1988 criou estruturas de ampliação da democracia representativa para uma forma deliberativa, criando mecanismos institucionais de participação que alteraram a estrutura de poder e criam espaços para a gestão compartilhada das políticas públicas. A intenção é criar mecanismos capazes de gerar consensos. Apesar de Teixeira (2000) considerar uma ilusão atribuir aos conselhos o papel de principal instrumento de participação cidadã, estes têm sido os estruturadores da democracia deliberativa no Brasil, principalmente nos municípios, e representam uma nova institucionalidade no Estado Brasileiro (TONELLA, 2006). Neles, membros do poder público e da sociedade civil são reconhecidos como iguais e constituem uma instância de deliberação (MONTEIRO; FLEURY, 2006). Fazem parte do novo espaço público não estatal, onde representantes da sociedade civil e do poder público se unem para "a gestão de parcelas da coisa pública que dizem respeito ao atendimento das demandas sociais" (GOHN, 2004, p.23).

Para Habermas (2003, p. 91) a esfera pública não compõe uma estrutura normativa que diferencie competências ou papéis, portanto se diferencia de uma instituição ou organização. Para o autor, ela é uma "rede adequada" para que sejam trocados conteúdos, opiniões, tomadas de decisões, filtrando e sintetizando, condensando opiniões públicas. Ela utiliza a ação comunicativa. Para Daniel (2000) os conselhos gestores de políticas 
públicas são formas de ampliação desta esfera pública, porque são novos canais que fortalecem os canais existentes para formação de opinião e tomada de decisão e ainda inserem novos temas na agenda política.

Estes colegiados são resultado, de um lado de um rompimento das características hierárquicas das políticas públicas dada pela maior autonomia dos municípios, de outro, da inclusão dos direitos sociais coletivos na gestão local (AVRITZER; PEREIRA, 2005).

Este processo de gestão através do ingresso da cidadania organizada na máquina do Estado possibilita conhecer seu funcionamento e seus limites e estimula a construção de uma relação de co-responsabilização e de disputa, visando produzir consensos cada vez mais qualificados (JACOBI, 2002, p.452).

A esfera pública como definida por Habermas é um processo de interação entre diversos grupos, entidades, organizações e movimentos sociais com espaço e funções diferentes da esfera estatal. Os novos atores têm o papel de influenciar as decisões governamentais e são interlocutores da ação comunicativa (TONELLA, 2006).

Os conselhos foram criados para o exercício da cidadania. São instituições que visam fortalecer a democracia. Apresentam elementos da democracia direta e indireta simultaneamente, buscando a inclusão de setores da população anteriormente excluídos. A participação direta nos conselhos não se realiza de forma individual, mas sob a representação através de membros eleitos de organizações da sociedade civil, o que é elemento da democracia indireta (LÜCHMANN, 2007; ANASTÁCIA; AZEVEDO, 2002). Avritzer e Pereira (2005) assim como Teixeira (2000) também denominam os conselhos como instituições híbridas, mas, para eles, o que atribui este caráter é o compartilhamento por atores governamentais e da sociedade civil nos processos deliberativos.

A quantidade de conselheiros varia de acordo com a regulamentação de cada conselho. No regimento interno também são 
definidas quais as entidades, entre os atores locais, que melhor representam os diferentes interesses no assunto tratado. Algumas das instituições representadas elegem seu conselheiro em assembléias ou fóruns abertos, enquanto outros já estão inseridos no conselho pelo regimento como decorrência do cargo que ocupam. Os conselhos representam um avanço no processo de participação social na tomada de decisão, mas ainda com limitações em suas realizações (HADDAD, 2005). Precisam assumir seu papel de espaço de explicitação e acomodação de conflitos e de decisão compartilhada (PONTUAL; ARAÚJO, 2005), assim como de controle da sociedade civil sobre o Estado (GOHN, 2007a). Mesmo sendo um instrumento de deliberação participativa institucionalizada há 20 anos, muitas vezes exercem pouca influência na gestão pública. Por esse motivo, tem-se levantado dúvidas quanto à sua capacidade deliberativa de fato, uma vez que os conselhos podem ser suscetíveis à manipulação política (CAMARGO 2003).

Os termos conselhos setoriais, gestores ou de políticas públicas referem-se aos mesmos conselhos (TEIXEIRA, 2000; TATAGIBA, 2002) apresentando atribuições de formulação e implementação de políticas públicas e participando de planejamento e fiscalização das ações governamentais. Os conselhos paritários têm metade dos membros que os compõem da sociedade civil e metade do poder público. O regimento interno é aprovado em plenária e encaminhado para o prefeito. Nele estão definidas a quantidade de membros e as categorias de entidades que têm direito a representação no colegiado. As instituições que irão representar a sociedade civil são eleitas por seus pares e os membros do poder público são escolhidos pelo executivo municipal. Eles podem ter poderes apenas consultivos ou poderes deliberativos. Seus membros não são remunerados e as reuniões são abertas à participação da sociedade, com direito à voz, mas sem direito a voto. Assim, os conselhos permitem a participação de grupos organizados da sociedade na elaboração, implementação e controle social de 
políticas públicas. Em outras palavras "definem o que deve ser feito, fiscalizam e avaliam o que foi feito" (ASSIS; VILLA, 2003). Por permitirem a co-gestão de políticas públicas, são uma forma de ampliar a democracia, abrigando a negociação entre os diferentes grupos de interesse existentes na sociedade (REPENTE, 2000). Para Gohn (2007a) são agentes de inovação e espaço de negociação de conflitos, constituindo a principal novidade em termos de políticas públicas deste início de milênio.

Os conselhos de representantes foram propostos pela primeira vez na Lei Orgânica do Município de São Paulo em 1989 como um espaço político não estatal no âmbito das subprefeituras. Os processos de orçamento participativo de algumas cidades também acontecem com apoio de conselhos paritários, formados por representantes das diversas subregiões do município e por membros do poder público suficientes para obter a paridade - Este é o caso de Santo André. Ao contrário dos conselhos setoriais apresentados anteriormente, que têm como objetivo gerir as políticas públicas de um determinado setor da administração pública, tanto os conselhos de representantes quanto os de OP são canais de recepção de demandas da população e prestação de contas.

Os conselhos surgiram como forma de alterar a estrutura de poder criando espaços de gestão compartilhada das políticas públicas. Eles têm sido o expoente da democracia deliberativa no Brasil, principalmente nos municípios (MONTEIRO; FLEURY, 2006). Estes colegiados têm ainda a função de empoderar a comunidade, tornando-a protagonista da sua história, direcionando os cidadãos para o seu crescimento, autonomia e a melhora de sua qualidade de vida. Para Fulks e Perissinotto (2006) a palavra poder, que está implícita em empoderamento, tem como definição genérica a "relação de conflito e de predominância" ou a "capacidade de influenciar o processo decisório, isto é, de impor aos outros um determinado curso de ação em relação a um assunto específico" (FULKS; PERISSINOTTO, 2006, p.67). Existem duas formas de saber quem está no poder, o "método 
posicional" e o "método decisional". O primeiro, está relacionado às posições estratégicas de poder ocupadas pelos indivíduos em dada comunidade; o segundo, associa-se ao "indivíduo ou grupo que, num processo decisório específico e conflituoso, [consiga] fazer com que suas preferências [prevaleçam] sobre as preferências dos demais" (FULKS; PERISSINOTTO, 2006, p.68).

O Estado tem papel fundamental na mobilização para a participação pública, mas, em locais onde existe uma história de governos descomprometidos com o bem-estar social evidenciam-se as dificuldades em se efetivar essa mobilização e a confiança é essencial para que a parceria entre Estado e sociedade se efetive (BONFIM; SILVA, 2003). Não existe infra-estrutura para a participação que funcione como atrativo, se o Estado não estiver engajado com o processo. Por isso, alguns trabalhos ponderam formas para que determinada demanda possa entrar para a agenda política. Souza (2006) aponta três caminhos. O primeiro diz respeito ao problema em si e à disposição para enfrentá-lo. O segundo relaciona-se com a política, expressa como ideologia partidária ou processo eleitoral. O último reconhece a força dos participantes visíveis do processo político, que inclui políticos, mídia, partidos e os grupos de pressão. Os conselhos abrem espaço para que a sociedade se coloque, mas, se não houver pressão social eles podem se tornar inoperantes (ALVIM et al., 2007). Bava (2005) também destaca a necessidade de se manter grupos de pressão ativos. Para o autor, mesmo que os eleitos se mostrem propensos a estimular processos participativos é necessário que haja pressão popular para mantê-los na agenda política. Afirma ainda: "[...] não conheço governo que abra mão do seu poder sem ser interpelado pela sociedade civil. Não podemos atribuir aos governantes uma tarefa que é da sociedade civil" (BAVA, 2005, p.37). A falta de pressão da população pode permitir que o Estado cumpra seu papel mobilizador dos processos participativos apenas de forma burocrática, comprometendo os resultados desses fóruns. 
A transparência do governo também pressupõe decisões políticas e econômicas para que as informações e sua comunicação possam ser disseminadas de forma ampliada. É necessário que haja disposição do poder público na definição de "o que informar?", "como atingir as diversas camadas de população?" e "qual a mídia adequada para efetivar a comunicação?" (SILVA; CRUZ; MELO, 2007). Existem limites para que a transparência se expresse de fato, pois não existem mecanismos de ordenação do relacionamento entre poder público e sociedade civil que controlem prestação de contas, autorização, responsividade e sanção (GURZA et al. apud LÜCHMANN, 2007).

Haddad (2005, p.96) aponta esses limites

As conseqüências disso são os limites colocados nesse diálogo, como os que nós vimos aqui: limites da democracia participativa, limites de conselhos que passam a ser meramente consultivos, não participativos e que, por isso, não avançam, limites de conselhos que não são paritários, limites de conselhos no qual a participação é definida pelo Estado e não pela sociedade, limites de acordo de compromissos que não são cumpridos, limites em relação ao acesso à informação e, finalmente, limites devido ao fato que essa participação não opera com recursos e, conseqüentemente, não opera com a política propriamente dita.

Uma das atribuições dos conselhos, principalmente entre os membros representantes da sociedade civil, é controlar o poder público, o que inclui a ação fiscalizatória, de transparência e de participação na gestão e no planejamento (TEIXEIRA, 2005).

Algumas dificuldades iniciais para a instalação dos conselhos nos municípios, decorrem dos limites que estas práticas democráticas impõem aos valores como o clientelismo e o paternalismo a muito enraizados na cultura política nacional (GOHN, 2007a). Em alguns casos os conselhos foram criados sob um discurso democratizante e uma prática 
"fantasmagórica", de cima para baixo, com o objetivo de legitimar um "pseudo processo democrático" (GOHN, 2007a, p.54).

A paridade nos conselhos ainda pode ser um entrave. "Participar de forma igualitária no processo de tomada de decisão, não apenas com caráter consultivo, mas também deliberativo, ainda é uma das principais metas dos conselhos municipais, porém a mais difícil de alcançar." (MONTEIRO; FLEURY, 2006, 231). Diversos trabalhos, como o de Teixeira (2000) apontam dificuldades com a paridade. Numericamente, estabelecer e manter a paridade em um conselho parece ser uma tarefa simples, mas, existe uma assimetria nas condições de participação dada por diversos fatores: os membros do poder público têm como trabalho diário as funções relacionadas com a administração pública e as reuniões de conselho se somam a elas, enquanto os representantes da sociedade civil têm no conselho uma outra atividade que se soma às profissionais e pessoais. 0 preparo para participar das discussões também tende a um desnível. Os conselheiros do governo normalmente têm grau de instrução maior e sua formação é direcionada para suas atividades no setor público, além de conhecer os aspectos técnicos e administrativos e estar familiarizado com o vocabulário, o que não acontece com freqüência entre os membros da sociedade civil. Além disso, há desigualdade no acesso às informações relevantes para a tomada de decisão. Teixeira (2000) afirma que existe uma assimetria de condições para a participação e que os membros da sociedade civil são heterogêneos e, em geral, de difícil articulação. Perissinoto ${ }^{28}$ também destaca as desigualdades entre as representações com relação às possibilidades de participação. Para os membros do poder público, o conselho é uma decorrência de seu expediente de trabalho e para os da sociedade civil é mais uma atividade em seu trabalho cotidiano. A natureza social fragmentada é outro limite para a capacidade de atuação dos conselhos na democratização das relações sociais e políticas e no controle da

28 Na apresentação do livro de Tonella (2006). 
gestão pública (TATAGIBA, 2002). Tonella (2006) constata que as atividades de capacitação servidas pelos órgãos públicos normalmente têm sido de pouca eficácia.

Outro fator que pode atravancar o funcionamento dos conselhos é o alto número de funções administrativas que podem ir postergando a inclusão de questões importantes na agenda (TEIXEIRA, 2000). Ivo (2002) constata que apesar da cultura democrática cada vez mais se afirmar como valor, existe um descontentamento com os resultados práticos dessas conquistas.

Bava (2005) diz que os conselhos setoriais se proliferam nos municípios e que em 2005 já existiam aproximadamente 27 mil conselhos paritários e deliberativos no país, a maioria nos municípios. Parte da responsabilidade por esta profusão de conselhos do nível municipal é seu caráter obrigatório como condição para o repasse de recursos. Porém, Tonella (2006) considera cedo para estabelecer um padrão único para os conselhos.

Para que os conselhos sejam de fato instrumentos de democracia, retoma-se Dahl (1997, apud SANTOS JUNIOR, 2001) que afirma que a responsividade contínua de um governo às preferências dos seus cidadãos é a característica chave da democracia.

A captação das preferências da população através de seus representantes nos conselhos e a resposta eficiente e efetiva do Estado devem ser os principais produtos da existência destes colegiados para que eles funcionem como elementos de governança. O Estado brasileiro abriu espaço para que estes instrumentos de democracia deliberativa se instalassem nos três níveis de governo como local onde os conflitos são evidenciados e os consensos gerados em um processo de contínua prática da democracia. Os cidadãos precisam estar preparados para assumir seu papel nestes espaços. 0 agir comunicativo deve permear as relações dentro dos 
conselhos e fora deles construindo os saberes em relações horizontais para que os representantes da sociedade civil possam expressa-los nos fóruns deliberativos. O Estado necessita ser pressionado para ampliar os espaços de co-gestão dos assuntos públicos. Esta pressão fez com que o Estado criasse estes espaços e precisa continuar existindo para que eles se aprimorem. Para que isto possa acontecer, é necessário mitigar as disparidades de condições entre representantes do poder público e da sociedade civil nestes colegiados. Considera-se que este é um processo valioso em construção, tanto que os processos participativos desenvolvidos no Brasil servem de modelo para gestões locais em outros países, como apresentado no exemplo que segue.

\subsection{ORÇAMENTO PARTICIPATIVO DO PLATEAU-MONT-ROYAL}

O orçamento participativo brasileiro é um processo estudado $^{29}$ e referenciado internacionalmente. Em 2008 a autora acompanhou o "Budget Participatif du Plateau-Mont-Royal", em Montreal, no Canadá. O Plateau-Mont-Royal é uma das subprefeituras de Montreal, e adota o OP desde 2006. Através de um acordo com o "Centre D'écologie Urbaine de Montréal" foi possível acompanhar o ciclo de 2008 desde o início, mas não até o final, uma vez que o estágio de doutoramento naquele país foi concluído em agosto daquele ano.

Já no primeiro slide das as apresentações realizadas para 0 processo de OP destaca-se a seguinte frase: "De Porto Alegre à Montréal" fazendo clara referência ao caso que inspirou o caso canadense. Como preparação para o primeiro ciclo do orçamento participativo, uma comissão do Plateau-Mont-Royal veio à Porto Alegre aprender com o caso de sucesso.

${ }^{29}$ Como, por exemplo, os estudos de Wampler (2007 e 2008) e o de Anne Latendresse (2004) citados nesta tese. 
A região da subprefeitura foi dividida em três distritos [mapa 1] e, em sua terceira edição, o "Budget Participatif du Plateau", contou com as seguintes etapas (PLATEAU-MONT-ROYAL, 2008):

- Etapa 1 - oficinas de iniciação com o objetivo de explicar para a população que não havia participado de nenhuma edição anterior, o que é o orçamento participativo; quais são os assuntos de competência da subprefeitura e quais se referem a outras esferas de governo; como o orçamento se organiza; quais foram as demandas priorizadas nas edições anteriores e em que estágio de implementação se encontravam. Esta etapa foi realizada três vezes em cada um dos três distritos, sete reuniões aconteceram em francês, sendo que uma reunião foi proposta em português, por ser o bairro onde se concentra a colônia de Portugal, e apenas uma em Inglês, na parte mais próxima à universidade McGill, por ser local de moradia da população anglofônica no bairro;

- Etapa 2 - foram realizadas as primeiras assembléias de distrito, onde as propostas foram levantadas e discutidas entre cidadãos, sendo em seguida submetidas à coordenação do processo. Cada participante pode submeter apenas um projeto em seu nome;

- Etapa 3 - é uma atividade interna à administração pública, visando separar os projetos que são de responsabilidade da subprefeitura; e avaliar seus custos, viabilidade e impactos. Nesta fase, os projetos que não se enquadram nas atribuições da subprefeitura são encaminhados para as estâncias pertinentes;

- Etapa 4 - realizada por meio das segundas assembléias de distrito: quando são escolhidos os projetos mais importantes 
e os representantes do distrito para a reunião de deliberação

- "le Sommet annuel".

- Etapa 5 - "le Sommet annuel", assembléia para a escolha dos projetos para toda a subprefeitura.

- Etapa 6 - adoção do orçamento pelo Conselho da subprefeitura $^{30}$. É quando ocorre a oficialização das escolhas populares.
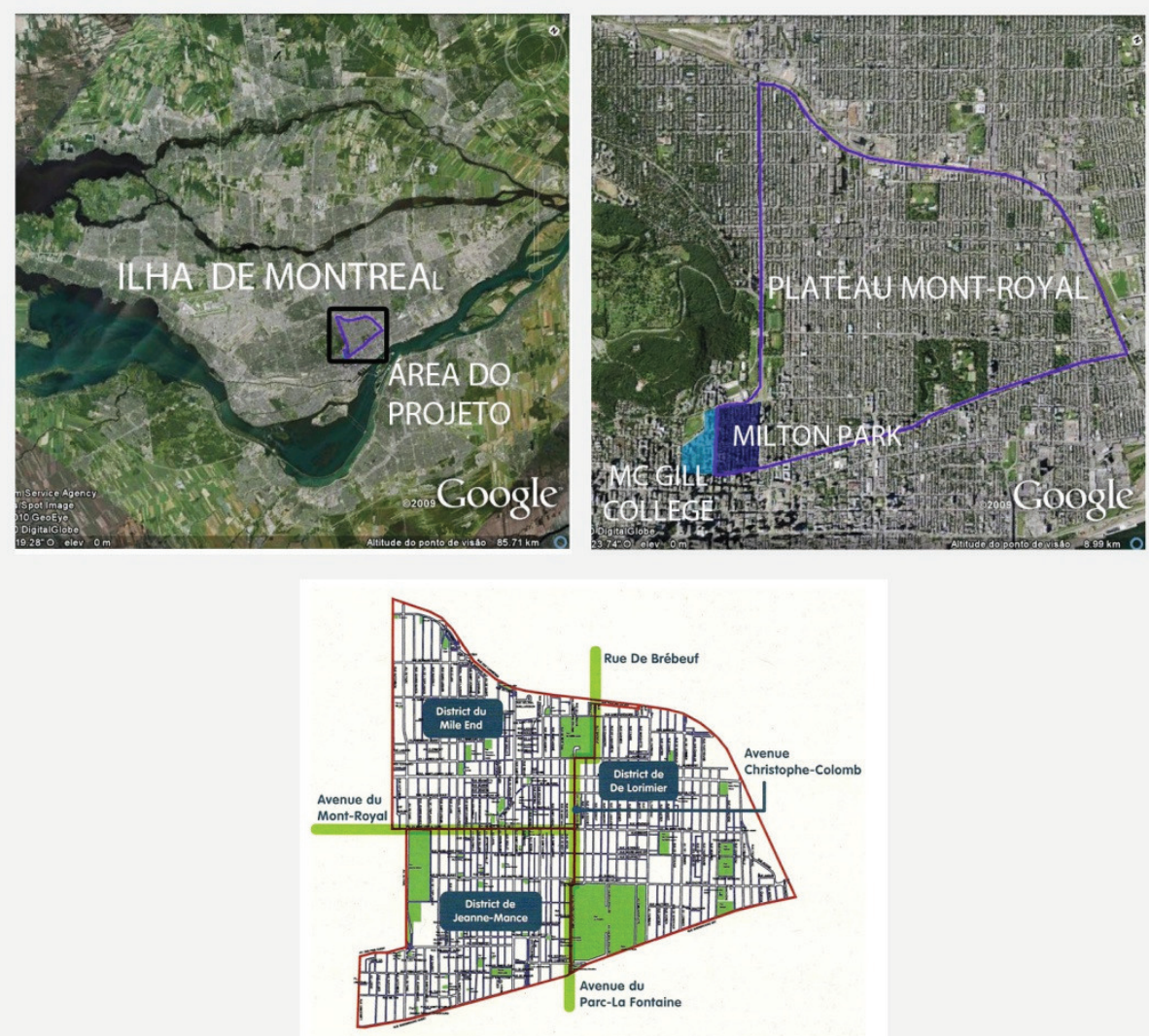

L'arrondissement du Plateau-Mont-Royal

Mapa 1: localização do Plateau-Mont-Royal e a divisão da subprefeitura em três distritos

Fonte: Preparado por esta tese a partir do Google por Bozeda, 2010 e PLATEAU-MONT-ROYAL $(2008$, p.8)

Apesar do envolvimento do grupo Centro de Ecologia Urbana de Montreal e da Subprefeitura do Plateau, notou-se o pouco envolvimento da população com o processo. 0 número de participantes em 2008, até o

30 "conseil d'arrondissement" no original

VENDRAMINI, Paula R. Jorge * A participação em conselhos como instrumento de gestão municipal 
momento que o processo foi acompanhado, era bem menor do que os envolvidos em 2007. Em um balanço realizado, foram levantadas duas possibilidades para esta queda na participação: problemas com a divulgação; e falta de demandas importantes por parte da população.

Lepage (2008) em sua coluna do jornal La Presse, fez duras críticas ao orçamento participativo, chamando-o de "exercício de demagogia". Diz que desta forma, os gestores eleitos abrem mão de seu poder deliberativo para seus cidadãos, de certa forma, abdicando de sua função, e privando de voz um grande número de cidadãos que não têm nem tempo e nem capacidade de participar, pois pelo voto, todos participam igualmente. Esta autora não recrimina a participação em si, pois a considera saudável, necessária e benéfica. No entanto, por razões de equidade, representatividade e eficácia, a democracia também precisa que chefes qualificados estejam conscientes das preocupações e necessidades de sua comunidade, e do interesse de todos, e não apenas de ativistas. Estas afirmações causam estranheza, tanto pela contradição entre o valor da participação e as críticas a não inclusão de todos os cidadãos, quanto, pelo fato de que a província de Quebec, incluindo Montreal, tem grande tradição na participação popular nas decisões de gestão ambiental e urbana, como aponta Gauthier (2005). Ocorre também que este é o mesmo tipo de participação que acontece na França, como conforme Bourdin (2001).

\subsection{CONSIDERAÇÕES DO CAPÍTULO}

O desenvolvimento sustentável é um desafio para os diversos níveis de administração pública. Garantir a justiça social, a adequação ambiental e a viabilidade econômica dos diversos processos das atividades humanas tem se mostrado uma tarefa complexa e pouco precisa. 
Esta complexidade aumenta quando se consideram os aspectos intra e intergeracionais. A maioria das abordagens delineia ligações entre as questões de desenvolvimento sustentável com as práticas socialmente inclusivas, tanto na forma de ação, quanto em seus propósitos, através da participação dos diversos atores na construção de estratégias de ação. Costa (1999) apresentou duas abordagens possíveis para essa problemática do desenvolvimento sustentável que levam a valorizar o estudo do desenvolvimento urbano sustentável. A primeira é a grande e crescente concentração de população mundial em áreas urbanas; a segunda, decorre do fato de que o espaço urbano, por um lado, é resultado das relações sociais e, por outro, pode ser um agente transformador destas relações.

Embora não haja uma definição exata da forma urbana típica desta era informacional, ou pós-moderna, existem premissas derivadas das principais propostas com relação às cidades sustentáveis. Nessas premissas o espraiamento da mancha urbana deve ser evitado, assim como o uso de automóveis. As cidades devem ter uma mistura de usos que torne os trajetos a pé mais freqüentes e um sistema de transportes públicos, preferencialmente alimentado por fontes limpas de energia, que torne o uso do carro desnecessário para a maioria das atividades rotineiras. Existem então, algumas propostas mais detalhadas espacialmente, como é o caso das cidades compactas e do novo urbanismo. Destaca-se a proposta das cidades sustentáveis da Califórnia que, mesmo apresentando as premissas descritas acima, têm o foco no processo participativo de tomada de decisão e não na forma urbana. Esta é uma experiência mais próxima da brasileira, onde o planejamento urbano tem cada vez mais um caráter de inclusão da população, seja na construção de planos diretores, que após a promulgação Estatuto da Cidade (BRASIL, 2001) em 2001 têm que ser participativos, seja nos conselhos gestores da política urbana municipal que são criados em alguns nos municípios. 
O desenvolvimento urbano sustentável incorpora as premissas de cidades sustentáveis descritas acima e avança na forma de gestão, que deve incluir os diversos atores sociais para discutir objetivos comuns, evitando os processos de segregação espacial e democratizando os serviços públicos.

O grande motivo para que estes espaços de decisão política fossem abertos para a participação da população está na perda de poder do Estado decorrente do processo de globalização, que transferiu para organizações supra-nacionais parte de seu poder. As organizações da sociedade civil se tornaram mais envolvidas com os serviços públicos e 0 sistema político se fragmentou (KJAER, 2004). Esta ruptura criou um desconforto num mundo acostumado a ter um centro de controle das diversas situações, afinal, "ninguém parece estar no controle agora" (BAUMAN, 1999, p.66). Os Estados fragilizados transferiram parte de seu poder para a sociedade civil, tornando-se co-produtores do bem público e trabalhando através de parcerias entre os setores público e o privado.

Existe, então, a necessidade de adequação da gestão pública; o Estado enfraquecido precisa incluir seus cidadãos nas instâncias de poder para ganhar legitimidade. Assim, a forma participativa ganha ênfase nos estudos de governança. Apesar desta ênfase de grande parte dos trabalhos na forma participativa da governança, entende-se que as ações públicas precisam ser efetivas e eficientes, além de participativas.

Desse modo, a interação entre a sociedade civil organizada e o poder público é valorizada. Estas novas formas de gestão trazem à tona o conceito de redes compostas por relações entre indivíduos ou instituições que são facilitadas pelas ferramentas de tecnologia da informação. A interação promovida por essas redes dá suporte à ação comunicativa como fala Habermas (2009), que é resultado da interação horizontal entre atores 
na busca de consensos sem coação externa, valendo-se apenas das regras informais internas ao grupo.

A discussão sobre governança foi impulsionada pelo Banco Mundial, que estabelece como condição para a cessão de financiamentos, que os países passem pelo "teste da democracia", comprovando ter respeito aos direitos humanos e aos padrões ambientais, assim como transparência, o que é necessário para a governança (GOHN, 2007a).

Soma-se a este cenário, o aumento da autonomia e das conseqüentes responsabilidades das administrações municipais. A progressiva descentralização impulsionada pela Constituição Federal de 1988 trouxe para os municípios atribuições para as quais estes não estavam preparados. Esta mesma Carta Magna criou e incentivou à implementação de mecanismos de inclusão de representação da sociedade civil organizada nos processos deliberativos de gestão de políticas públicas, que, segundo Jacobi (2002) é uma forma diferenciada de democracia representativa. Esta participação tende a enriquecer as políticas públicas, uma vez que nenhum dos atores envolvidos em processos de gestão de problemas locais tem sozinho o conhecimento e os recursos para resolvê-los, o que torna a interação entre eles, positiva. Quanto mais desenvolvido o sistema de participação cívica, maiores são as chances de que os cidadãos trabalhem em prol de objetivos comuns, como diz Putnam (2006). A intenção dos processos participativos é criar mecanismos capazes de gerar consensos.

Os conselhos brasileiros fazem parte do novo espaço público não estatal, para que representantes da sociedade civil organizada e do poder público se unam para juntos gerirem assuntos públicos, inclusive as políticas públicas. Estes conselhos abrem espaço para que a população se posicione, mas dependem de pressão social para se tornarem operantes (ALVIM et al., 2007). Foram criados para fortalecer a democracia através do exercício da cidadania. A participação nos conselhos acontece através de 
membros eleitos da sociedade civil organizada que representam suas instituições e de membros do poder público escolhidos pelo executivo. São então consideradas instituições híbridas. Os conselhos surgiram como forma de alterar a estrutura de poder, criando espaços de gestão compartilhada das políticas públicas, e por isto têm sido o elemento mais importante da democracia deliberativa brasileira (MONTEIRO; FLEURY, 2006); assim têm a função de empoderar a comunidade, tornando os cidadãos mais autônomos e melhorando sua qualidade de vida, além de torná-los fiscais da ação pública.

Haddad (2005) aponta diversos limites que ainda persistem em alguns conselhos, como: a não garantia de paridade entre poder público e sociedade civil; a não deliberação, tornando os conselhos meramente consultivos; o não cumprimento de compromissos estabelecidos; a falta de acesso às informações; a escolha de participantes pelo Estado e não pela sociedade civil; e o fato de alguns conselhos não operarem com a política propriamente dita. Ivo (2002) diz que a cultura democrática cada vez mais se afirma como valor, mas que ainda existe um descontentamento com os resultados práticos destas conquistas. Reconhece-se estas dificuldades, mas observa-se que os mecanismos participativos brasileiros servem de modelo para algumas experiências no exterior. Os conselhos se proliferaram principalmente nas cidades. Como conseqüência da diversidade de municípios brasileiros - tanto com relação ao tamanho, recursos humanos e financeiros disponíveis, quanto com relação à pré-disposição política de seus líderes à inclusão de processos democráticos na administração dos assuntos públicos - existem municípios com diferentes graus de abertura para a participação em conselhos e existem conselhos em diferentes condições de funcionamento. 



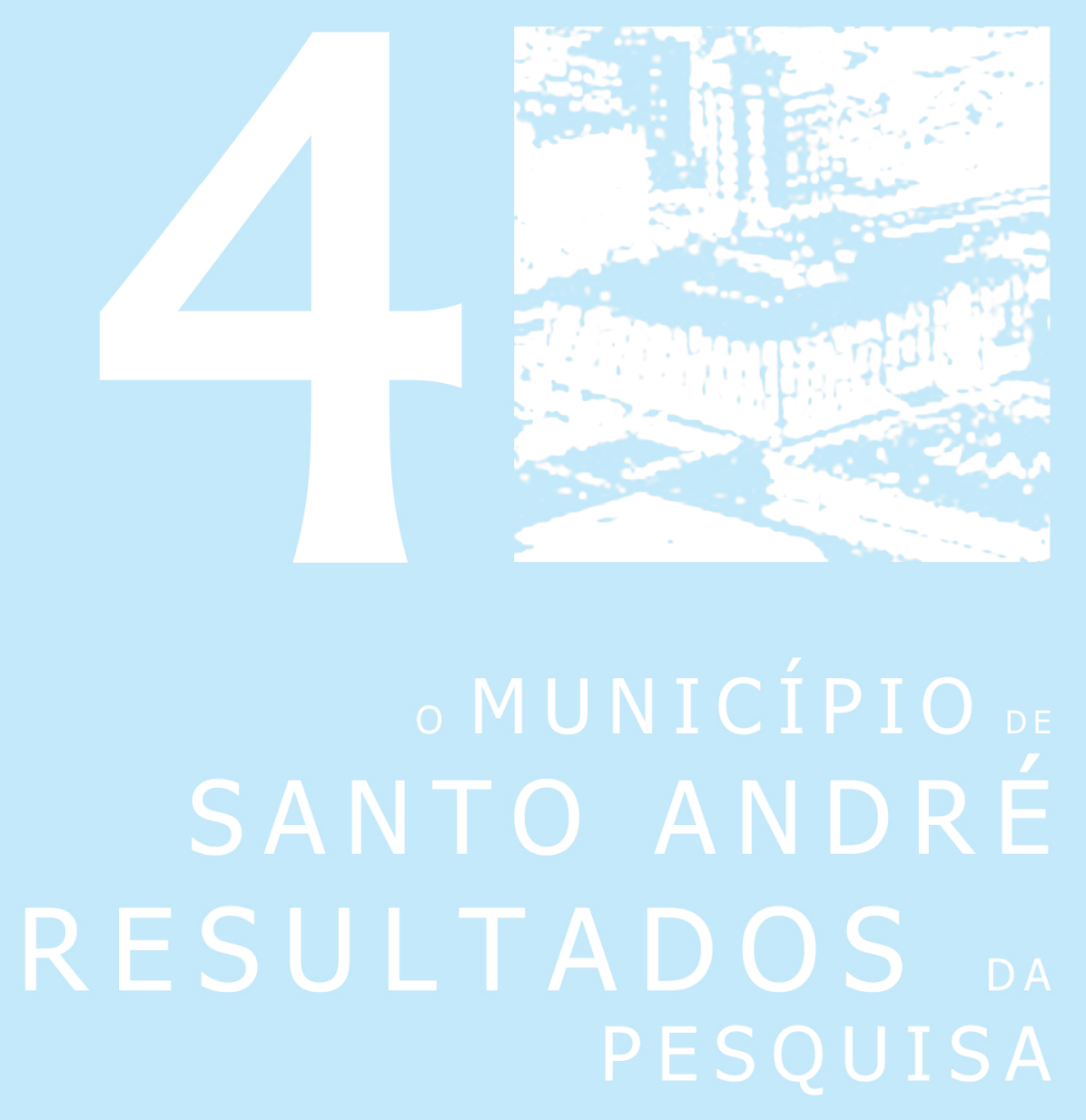





\section{MUNICÍPIO DE SANTO ANDRÉ: RESULTADOS DA PESQUISA}

Neste capítulo são organizados e analisados os dados de campo, dados documentais e entrevistas. Inicia apresentando o município de Santo André, com suas principais características, pequenos mapas e fotos obtidos em visitas de campo realizadas em carro da prefeitura e com acompanhamento de profissionais ligados à área de planejamento territorial e urbano do município ${ }^{31}$. Além das características territoriais, são expostos os aspectos administrativos, principalmente no que tange à gestão participativa municipal.

As entrevistas são apresentadas em duas etapas. O primeiro bloco de entrevistas foi realizado na fase exploratória do projeto e busca explicitar como se dá o processo de formulação de políticas públicas no município e sua implantação. Para tanto, foram entrevistados quatro gestores locais ${ }^{32}$ que trabalham com gestão de políticas públicas nas instituições municipais relacionadas aos quatro conselhos estudados neste trabalho:

- representantes da Secretaria de Desenvolvimento Urbano e Habitação, que gere o Conselho Municipal de Política Urbana (CMPU);

- representantes do Serviço Municipal de Saneamento Ambiental de Santo André (SEMASA), autarquia que gere o Conselho Municipal de Gestão e Saneamento Municipal de Santo André (COMUGESAN);

${ }^{31}$ Assim como em visitas da equipe de pesquisadores do Projeto MEGA.

${ }^{32}$ Foi desenvolvido um Termo de Consentimento Esclarecido, que informou os entrevistados de seus direitos, tais como interromper a entrevista sem nenhum ônus, e onde a equipe se compromete a manter o anonimato das respostas. Por este motivo, em nenhum local do trabalho serão apresentados os nomes dos entrevistados. 
- representante da Secretaria de Orçamento e Planejamento Participativo, secretaria que gere o Conselho Municipal de Orçamento (CMO), responsável pelo funcionamento do Orçamento Participativo (OP) de Santo André;

- e, por fim, o representante da Subprefeitura de Paranapiacaba e Parque Andreense, que gere o Conselho de Representantes de Paranapiacaba e Parque Andreense (CRPPA).

Antes do segundo bloco de entrevistas, apresenta-se a regulamentação dos quatro conselhos. Dois deles, regidos por leis, e, os outros dois, pelo regimento interno.

Em seguida, inicia-se o segundo bloco de entrevistas que trata do funcionamento dos conselhos propriamente ditos. Aqui foram analisadas nove das vinte questões aplicadas aos conselheiros municipais (conforme o item Metodologia - Entrevistas aos Conselheiros Municipais), tanto representantes do poder público, quanto da sociedade civil. As respostas foram analisadas de forma horizontal, ou seja, questão a questão. Primeiro analisou-se por conselhos e representação, como, por exemplo, conselheiros do poder público no CMPU. Em seguida a análise foi feita por conselho, independente da representação, e, no final, uma visão geral dos quatro conselhos. Trechos dos discursos dos entrevistados, que visam exemplificar as respostas dadas, estão entremeados com as análises das entrevistas.

Sempre que determinado dado é apresentado para os quatro conselhos, buscou-se manter a seqüência destes na ordem de análise: CMPU, COMUGESAN, CMO e CRPPA, visando facilitar a leitura. Os dois primeiros são semelhantes, pois referem-se a gestores de políticas públicas. Os dois últimos têm sua similaridade baseada no objetivo, de ser um canal 
de acesso das demandas da população ao poder público e um local de prestação de contas do poder público perante a população. Para auxiliar no acompanhamento do trabalho, foram montados gráficos respeitando-se a ordem de conselhos e as seguintes cores: azul para CMPU; verde para COMUGESAN; laranja para CMO e roxo para CRPPA. Para os quatro conselhos, optou-se por cores mais escuras para os conselheiros do poder público e mais claras para os da sociedade civil.

Todos os dados utilizados para o desenvolvimento desta análise referem-se à gestão que terminou em 2008 e foram colhidos entre 2007 e 2008. Este material aqui apresentado subsidia a análise da qualidade da atuação dos conselhos, em Santo André.

\subsection{O MUNICÍPIO DE SANTO ANDRÉ}

O Município de Santo André pertence ao chamado Grande ABC da Região Metropolitana de São Paulo (RMSP) composto por: Santo André, São Bernardo do Campo e São Caetano do Sul, que, com suas iniciais dão nome à região, que inclui ainda Diadema, Mauá, Ribeirão Pires e Rio Grande da Serra [mapa 2]. Esta região do Grande ABC localiza-se a sudeste do município de São Paulo e desenvolveu-se com a expansão industrial, principalmente automobilística, em meados do século XX. Após o grande incremento da produção industrial durante o milagre econômico da década de 1970, a indústria de Santo André, assim como aconteceu em vários países, passou por uma forte crise. Nas décadas seguintes iniciou-se a chamada reestruturação econômica e o emprego nas indústrias, assim como a arrecadação dos municípios industriais, diminuiu. 

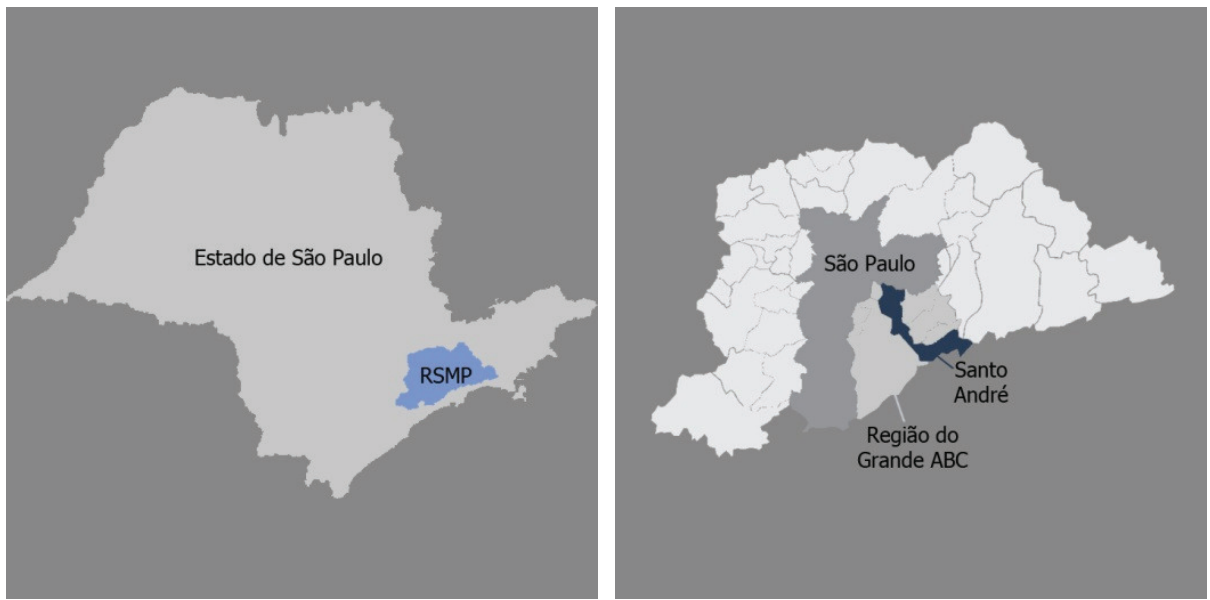

Mapa 2: localização - Estado - RMSP - ABC - Santo André

Fonte: Preparado por esta tese por Bozeda, 2010.

O município tem seu território dividido em duas partes por um braço da represa Billings, e cada uma delas tem uma ocupação bem distinta. A área a noroeste abriga 99\% dos aproximadamente 650 mil habitantes (censo IBGE 2000) e é conurbado com São Paulo, São Caetano do Sul e São Bernardo do Campo e Mauá. Separados da mancha urbana principal pelo braço do Rio Grande, os $55 \%$ da área municipal que compõem a parte sudeste abrigam apenas $1 \%$ da população e estão em Área de Proteção e Recuperação dos Mananciais. É nesta parte da cidade que fica a Vila de Paranapiacaba ${ }^{33}$ [mapa 3].

A porção d'água que separa Santo André em duas partes não é transposta no território do município nem por ponte, nem por balsa. Isto faz com que, para passar de um lado para o outro, seja necessário dar a volta pelo norte, passando por Mauá, Ribeirão Pires e Rio Grande da Serra, ou pelo sul, passando por São Bernardo do Campo.

33 Paranapiacaba é uma vila construída pela Companhia de Estrada de Ferro inglesa no século XIX. Atualmente pertence ao município e é patrimônio histórico tombado pelo Conselho de Defesa do Patrimônio Histórico, Artístico e Turístico do Estado de São Paulo (CONDEPHAAT). 


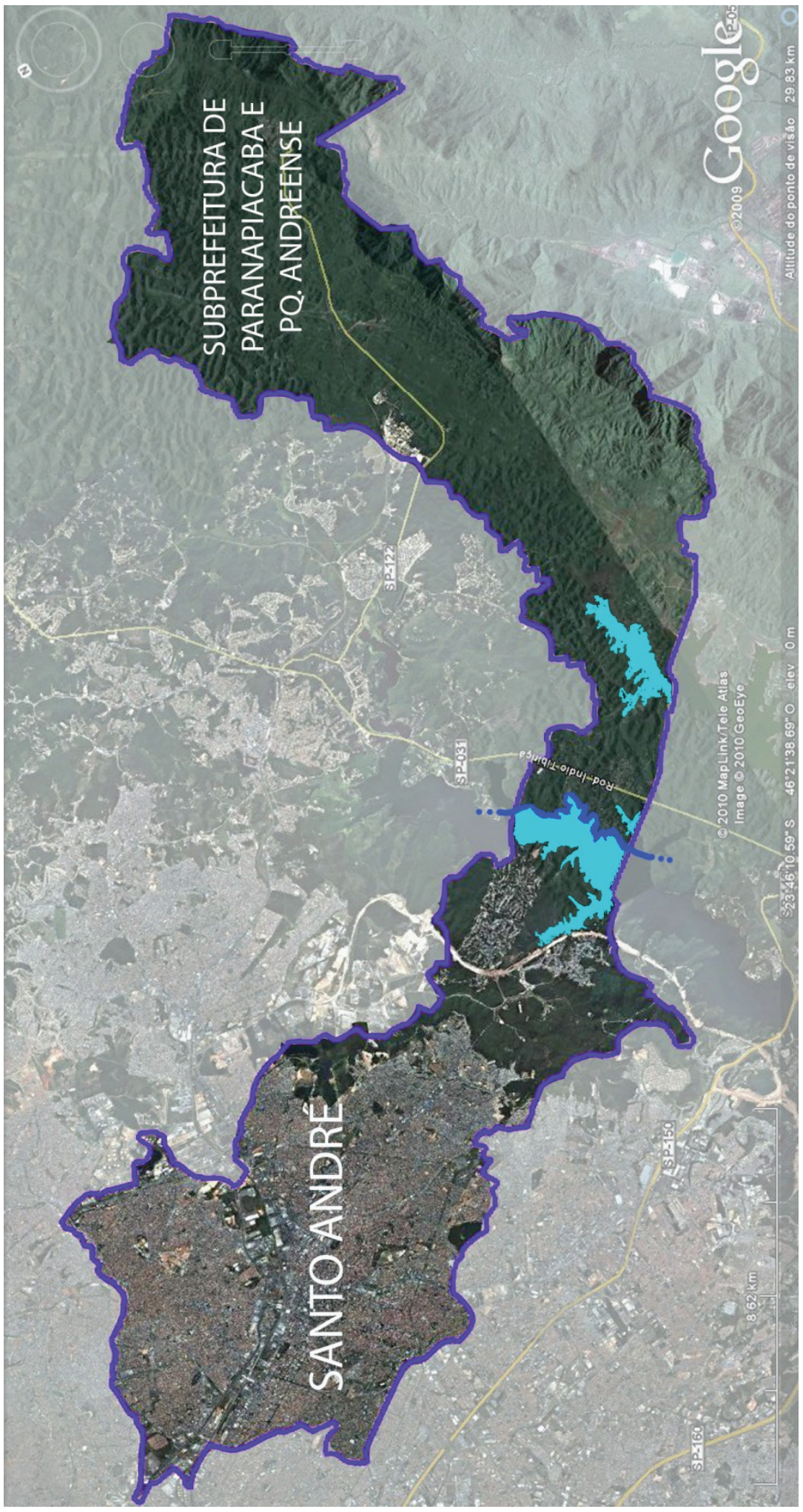

Mapa 3: Município de Santo André

Fonte: Preparado por esta tese a partir do Google por Bozeda, 2010. 
O Município de Santo André abriu espaço para a gestão participativa a partir de 1989, com os primeiros anos do orçamento participativo, ainda consultivo naquela época. A presença do ex-prefeito Celso Daniel foi muito marcante no governo de Santo André, fato este que pode ser reiterado pelo resultado da pesquisa apresentada por Morais (2004) que demonstra que o cidadão andreense faz uma associação entre município e prefeito. Em seu segundo mandato, este administrador reiterou a disposição de abrir canais de comunicação entre poder público e sociedade civil: tornou o orçamento participativo um fórum deliberativo; criou o PIIS/SAMI; também implantou o Projeto Cidade Futuro que em 2001 se divide em Projeto Eixo Tamanduatehy e Projeto Cidade Futuro; e o Plano Diretor Municipal participativo em 2001; finalmente criou inúmeros conselhos municipais que atuam até os dias de hoje em Santo André. Vale ressaltar que, como será apresentado, dois destes projetos receberam prêmios: o SAMI e o Plano Diretor Municipal.

A gestão participativa de Santo André tem sido pioneira e fruto de diversos trabalhos acadêmicos, servindo de exemplo para outros municípios, que observam seu funcionamento e utilizam como referência. Por outro lado, por ser pioneiro, Santo André tem dificuldade em encontrar exemplos de outros municípios com sucesso neste tipo de gestão, principalmente exemplos de cidades em regiões metropolitanas ocupando área de mananciais, que possam servir de exemplo para o governo andreense.

Outro problema enfrentado é a falta de certezas e muita experimentação necessária na formação de novos processos. Tem-se a noção de que existem ganhos, mas que a gestão participativa não está totalmente construída, e que, se foram realizadas conquistas, ainda há muito que caminhar. 


\subsubsection{A Área Urbana de Santo André}

A visita oficial à área urbana de Santo André foi realizada no segundo semestre de 2007 utilizando-se transporte cedido pelo SEMASA e foi acompanhada por um arquiteto da Secretaria de Desenvolvimento Urbano e Habitação. Nessa ocasião visitou-se a porção noroeste do Município, onde se concentra a população.

Pôde-se identificar uma estrutura viária que tem como eixo principal de acesso a Av. dos Estados, continuação da Av. do Estado paulistana, que acompanha o curso do rio Tamanduateí e a ferrovia que liga a capital paulista a Santos. Foi neste eixo que se instalaram as grandes indústrias do município e que foi parcialmente abandonado por estas a partir dos anos de 1970. Atualmente, estes galpões, cujo uso original foi industrial, estão cedendo lugar a novos usos, tais como Shopping Centers ou Conjuntos Habitacionais. É na Av. dos Estados que se encontra o Parque Celso Daniel e, no extremo leste desta avenida, próximo à divisa com o município de Mauá, encontra-se o Polo Petroquímico de Capuava. Partem deste eixo em direção ao sul três outras vias importantes: Av. Capitão Mario Toledo de Camargo, chamada de Marginal Guarará, a Av. Pereira Barreto e a Av. Prestes Maia [mapa 4]. 


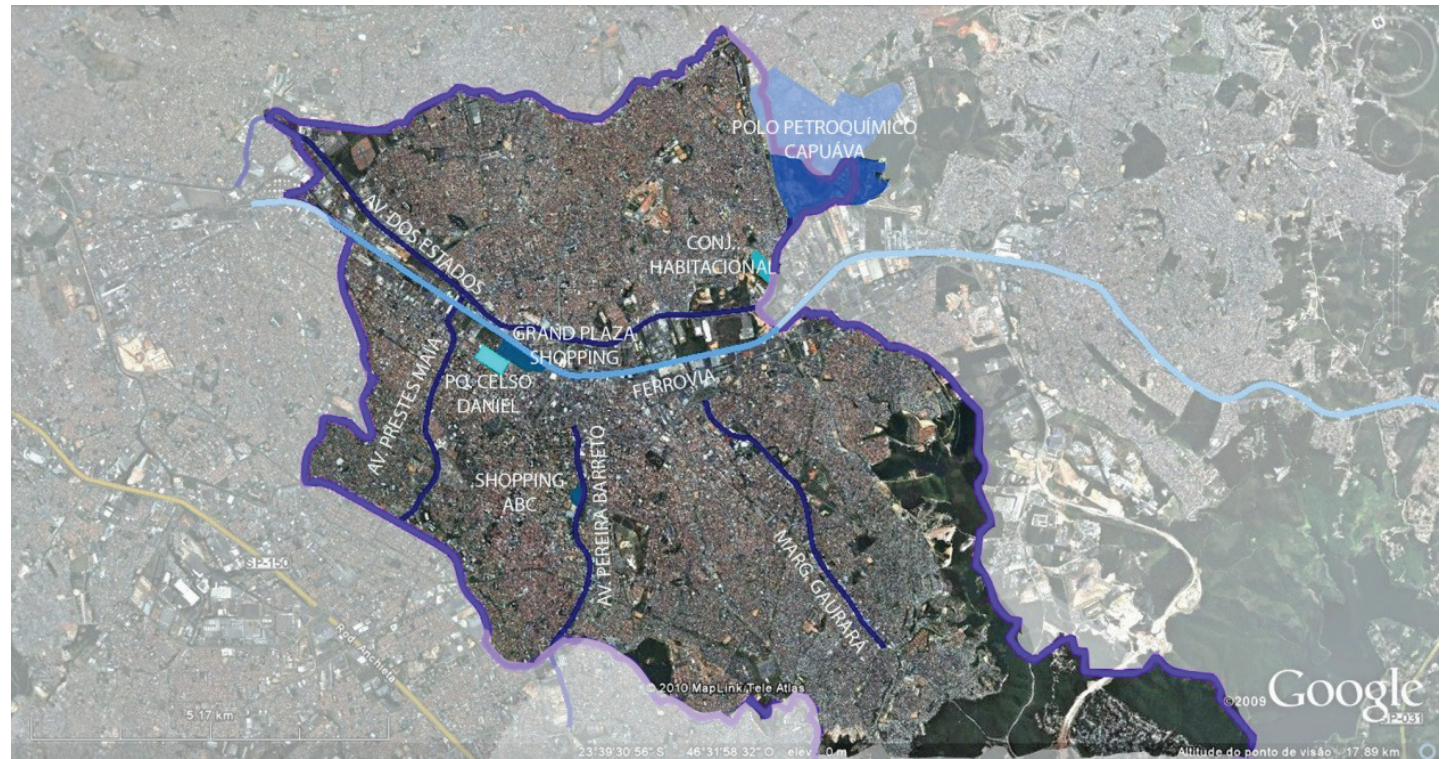

Mapa 4: principais eixos de Santo André

Fonte: Preparado por esta tese a partir do Google por Bozeda, 2010.

O centro antigo de Santo André [figuras 2 e 3] situa-se próximo da ferrovia, e, em seu entorno estão alguns dos bairros mais antigos do município, como o bairro Casa Branca [figuras 4 e 5], onde coexistem residências e indústrias. Suas construções datam do início do século XX. Os pequenos galpões industriais do antigo centro foram adaptados e atualmente estão ocupados por supermercados, concessionárias de automóveis, entre outros, que convivem com pequenas e grandes indústrias, como é o caso da Firestone, de pneus.

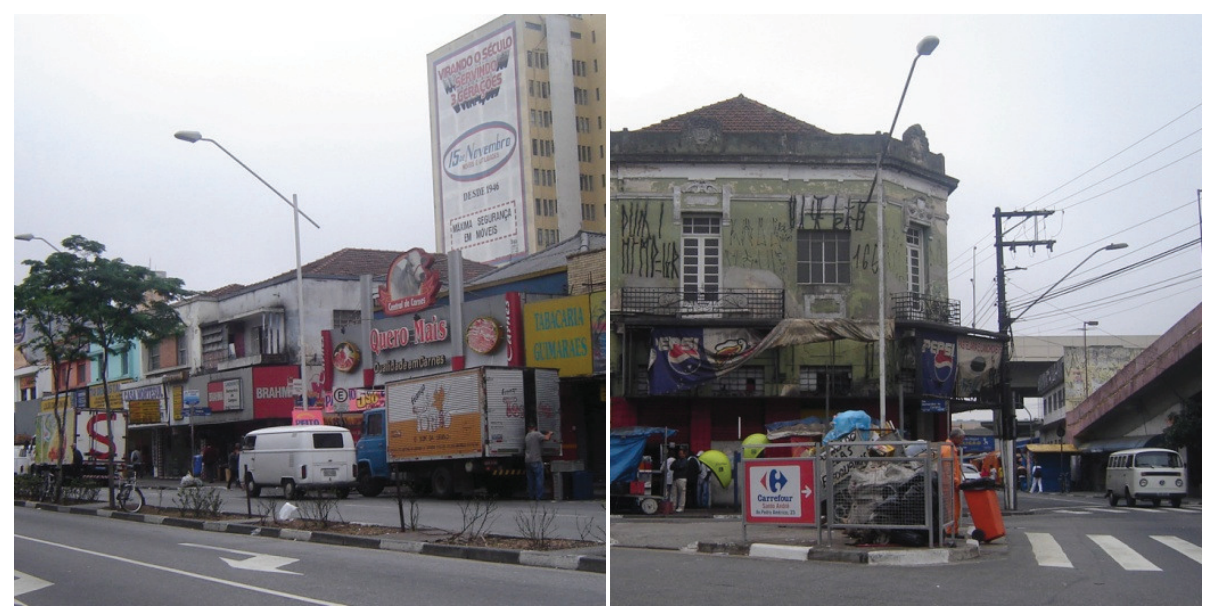

Figuras 2 e 3: centro antigo de Santo André Fonte: Projeto MEGA, 2007. 

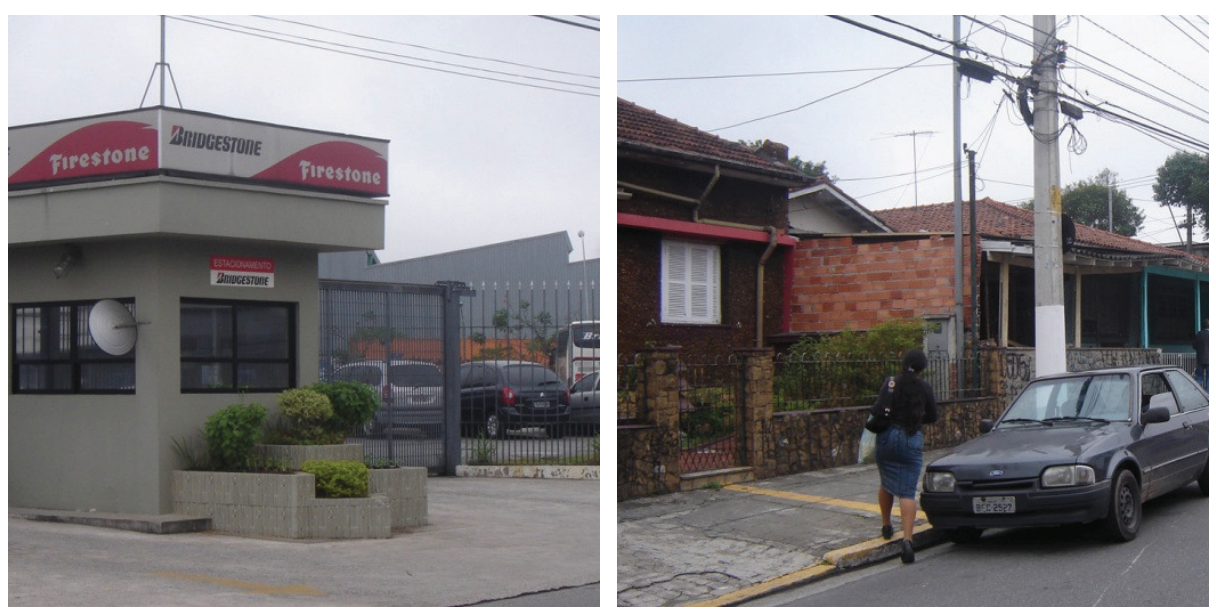

Figuras 4 e 5: bairro Casa Branca

Fonte: Projeto MEGA, 2007.

A Chamada Marginal Guarará, formada pela Avenida Capitão Mario Toledo de Camargo, acompanha o córrego Guarará [figuras 6 e 7]. Ela é o eixo de ligação com o sul da cidade e o Parque Pedroso e, para tanto, abriga um corredor de ônibus. Ladeando esta avenida encontram-se bairros com características bastante distintas, como, por exemplo, a Vila Pires [figura 8]: bairro de classe média com construções de meados do século XX com ruas largas onde moravam operários e funcionários administrativos das indústrias instaladas no entorno; ou exemplo do Jardim Ipanema [figura 9], do lado oposto da Marginal Guarará, que ocupado irregularmente, teve sua situação regularizada. Este último é formado por lotes pequenos e médios e abriga população de baixa renda. 

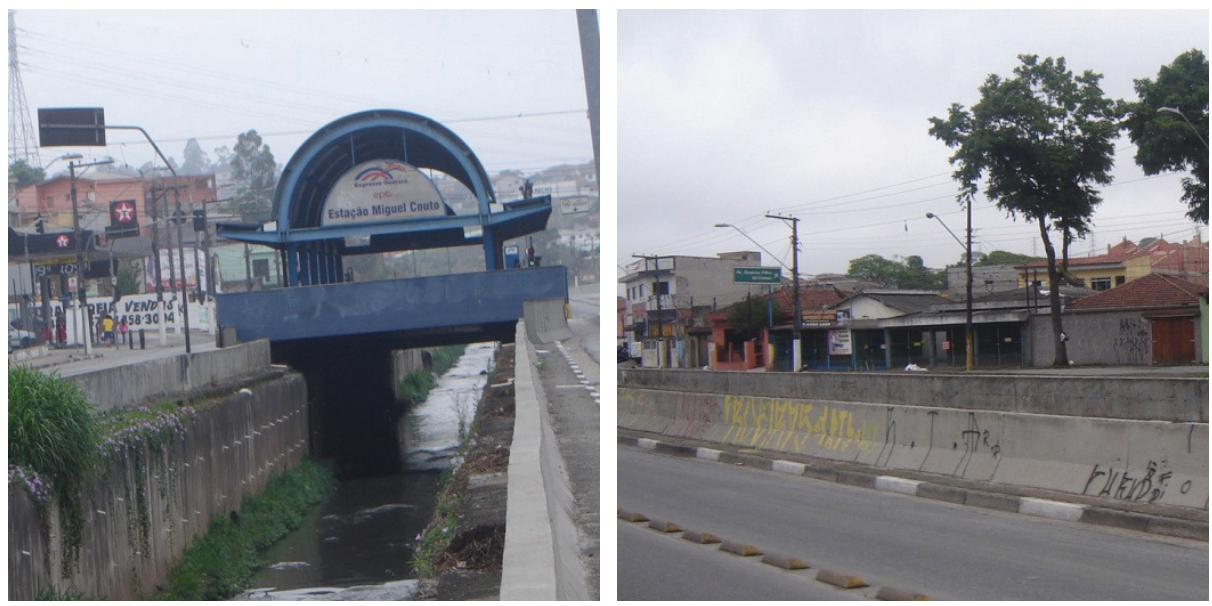

Figuras 6 e 7: Marginal Guarará Fonte: Projeto MEGA, 2007.
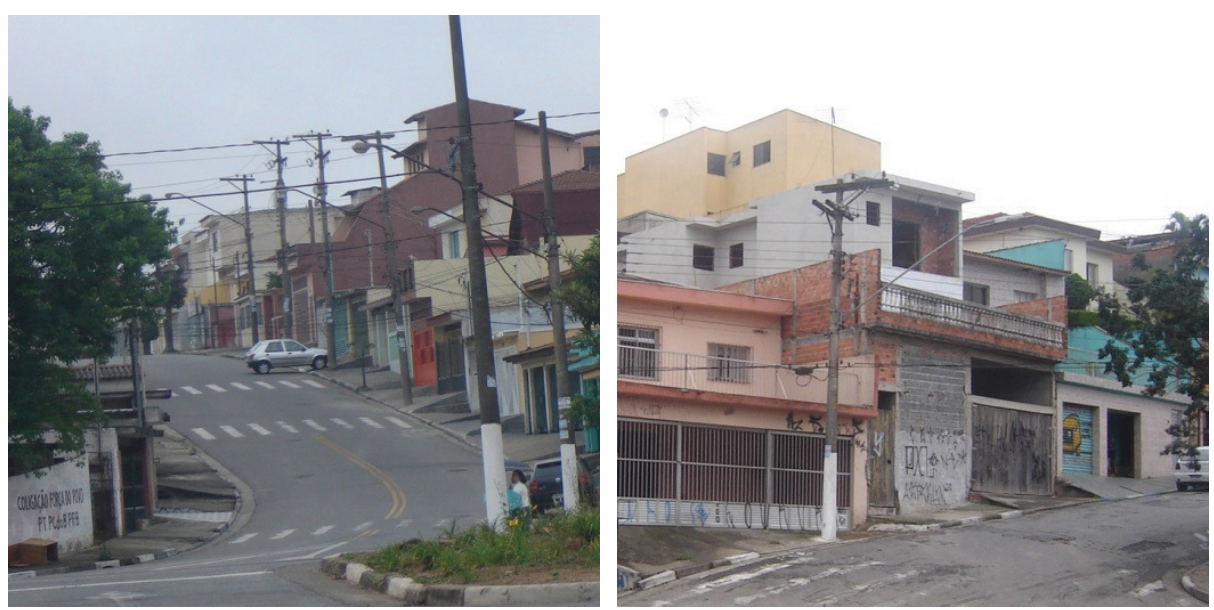

Figuras 8 e 9: Vila Pires (esq.) e Jardim Ipanema (dir.)

Fonte: Projeto MEGA, 2007.

Ainda na Marginal Guarará estão localizados: uma Estação de Tratamento de Água (ETA) [figura 10], administrada pelo SEMASA, e que trata $5 \%$ da água potável consumida no município ${ }^{34}$; o Estádio Bruno Daniel [figura 11], construído na década de 1970 sobre um antigo lago formado pelo represamento do córrego; O Clube Aramaçan [figura 12]o Cemitério Santo André, em cujo entorno foi demarcada um grande área como Zona Especial de Interesse Social (ZEIS) e o Parque da Juventude [figura 13].

34 O restante da água potável do município, assim como a maior parte do tratamento de efluentes é negociada com a Companhia de Saneamento Básico do Estado de São Paulo, a SABESP. 

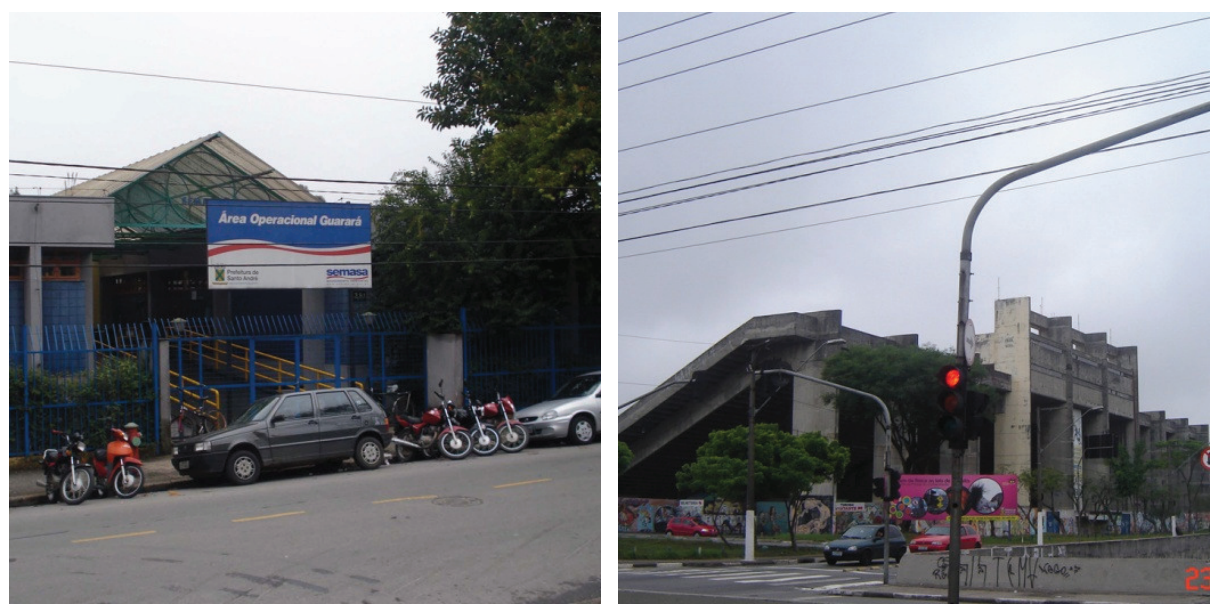

Figuras 10 e 11: Estação de Tratamento de Água (esq.) e Estádio Bruno Daniel (dir.)

Fonte: Projeto MEGA, 2007.
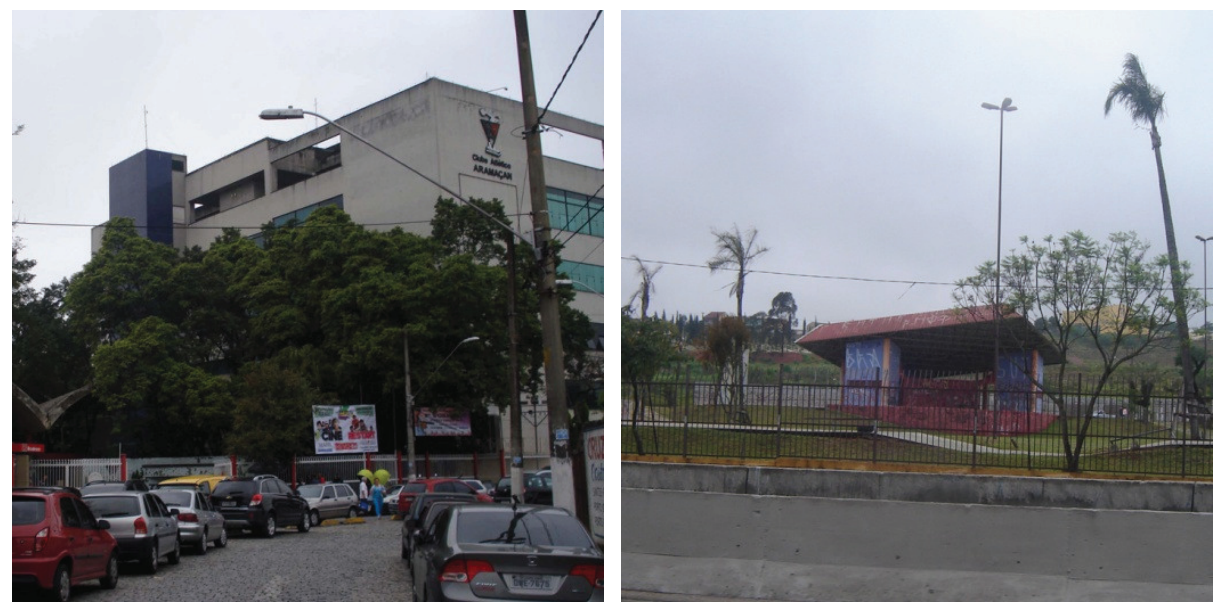

Figuras 12 e 13: Clube Aramaçan (esq.) e Parque da Juventude (dir.) Fonte: Bozeda, 2010 (esq.) e Projeto MEGA, 2007 (dir.).

No extremo sul da marginal Guarará localiza-se uma Área de Recuperação e Proteção dos Mananciais chamada Parque do Pedroso [figuras 14 e 15], local com ocupação menos densa e que margeia o braço do Rio Grande que divide o Município. Nesta região, existe uma grande de ocupação sobre a área de mananciais o que acarreta problemas ambientais e de abastecimento. 

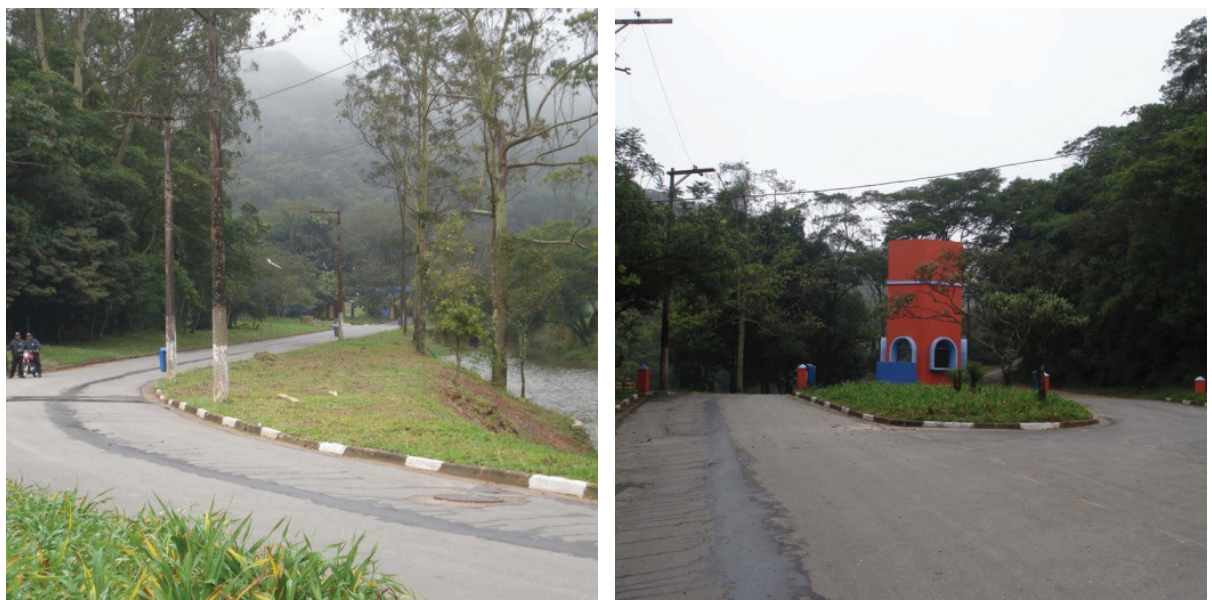

Figuras 14 e 15: Parque do Pedroso

Fonte: Bozeda, 2010.

O segundo eixo viário com origem na Av. dos Estados, passa pelo centro novo do município [figuras 16 e 17] e continua na Av. Ramiro Corleone e Av. Pereira Barreto. O centro do município tem um processo de verticalização consolidado que teve origem na década de 1980. Aqui estão localizados os bairros de alto padrão, como o Jardim Boa Vista, a Vila Assunção e a Vila Gilda. Ao longo da Av. Ramiro Corleone encontra-se o Shopping ABC [figura 18] e uma grande concentração hospitalar, que inclui o Hospital Estadual Mario Covas [figura 19], como também o Parque Central [figuras 20 e 21], onde está instalada a Sabina Escola Parque do Conhecimento parque este, que teve origem numa área encravada entre fundos de lotes e cujas ocupações irregulares formam a Favela Gamboa, localizada na área do parque, e que está em processo de remoção das famílias para a região de Capuava. 

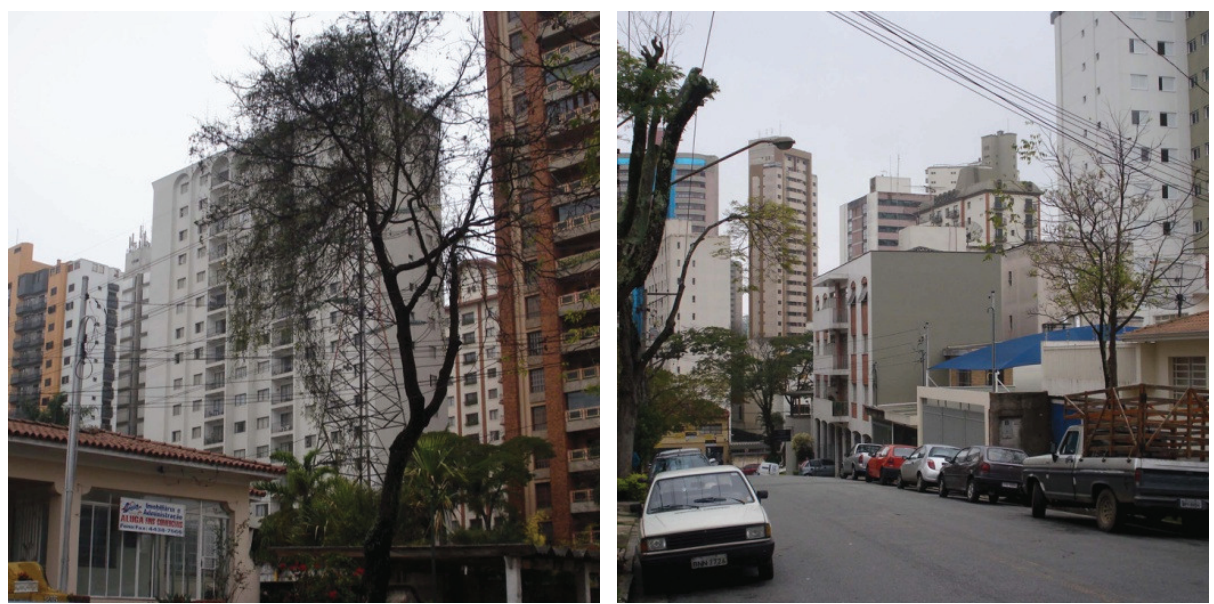

Figuras 16 e 17: Centro novo Fonte: Bozeda, 2010.
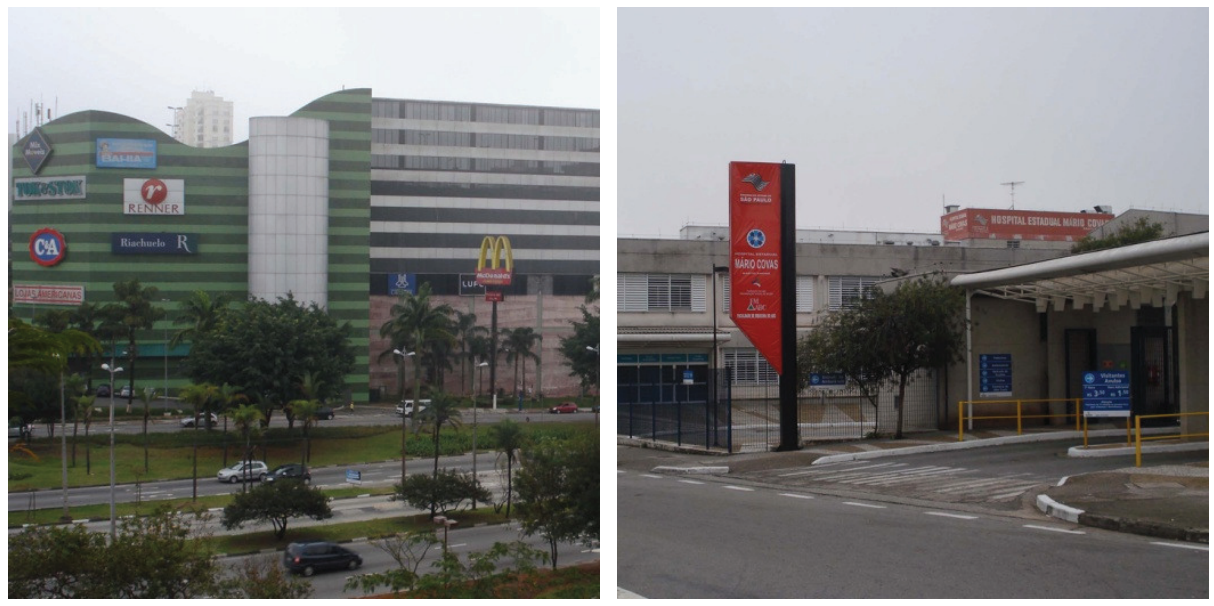

Figuras 18 e 19: Shopping ABC (esq.) e Hospital Mario Covas (dir.) Fonte: Bozeda, 2010.
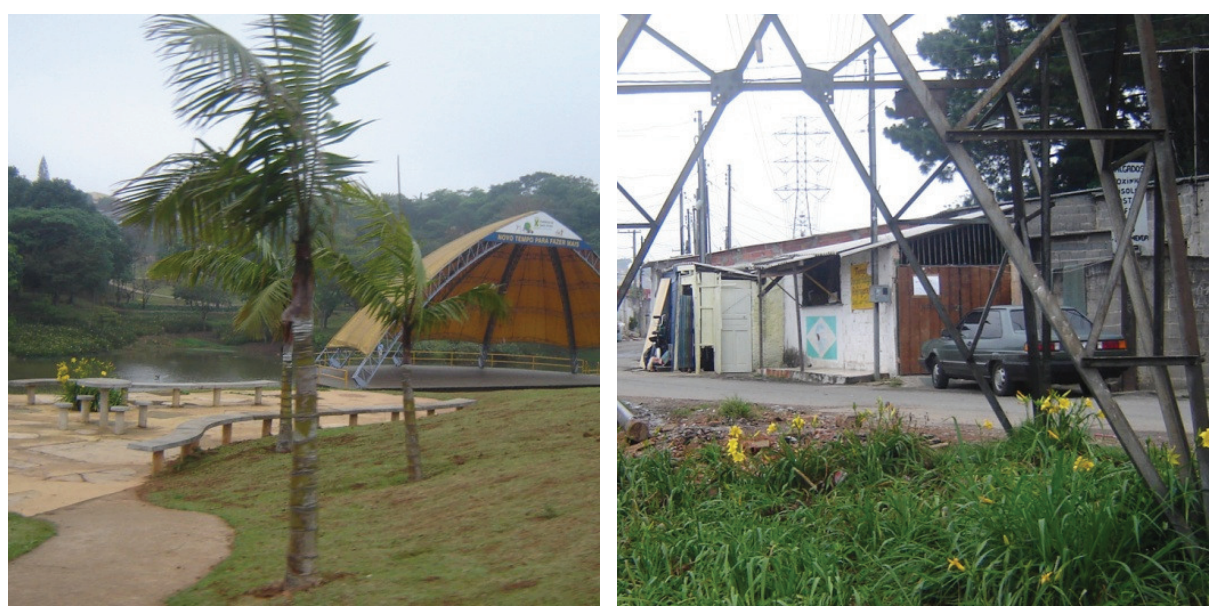

Figuras 20 e 21: Parque Central Fonte: Projeto MEGA, 2007. 
Por fim, o terceiro eixo [figura 22 e 23] com origem na Av. dos Estados, é o da Av. Prestes Maia, que liga Santo André a São Bernardo do Campo. Ainda em sua origem, próximo ao eixo do rio Tamanduateí, encontra-se a Estação Santo André [figura 24], que é composta por estação rodoviária, terminal de ônibus urbano e estação de trem. Neste eixo estão ainda localizados o SESC [figura 25], o Cadeião [figura 26] e o Condomínio Prestes Maia [figura 27], que foi construído pela prefeitura para abrigar famílias removidas de área de risco e favelas. Aqui também está localizada a favela Sacadura Cabral [figura 28 e 29], urbanizada em 1997 pelo Projeto Santo André Mais Igual (SAMI) com o Centro de Negócios e Serviços Sacadura Mais Igual, onde há um posto de atendimento da prefeitura, além de comércio de conveniência.
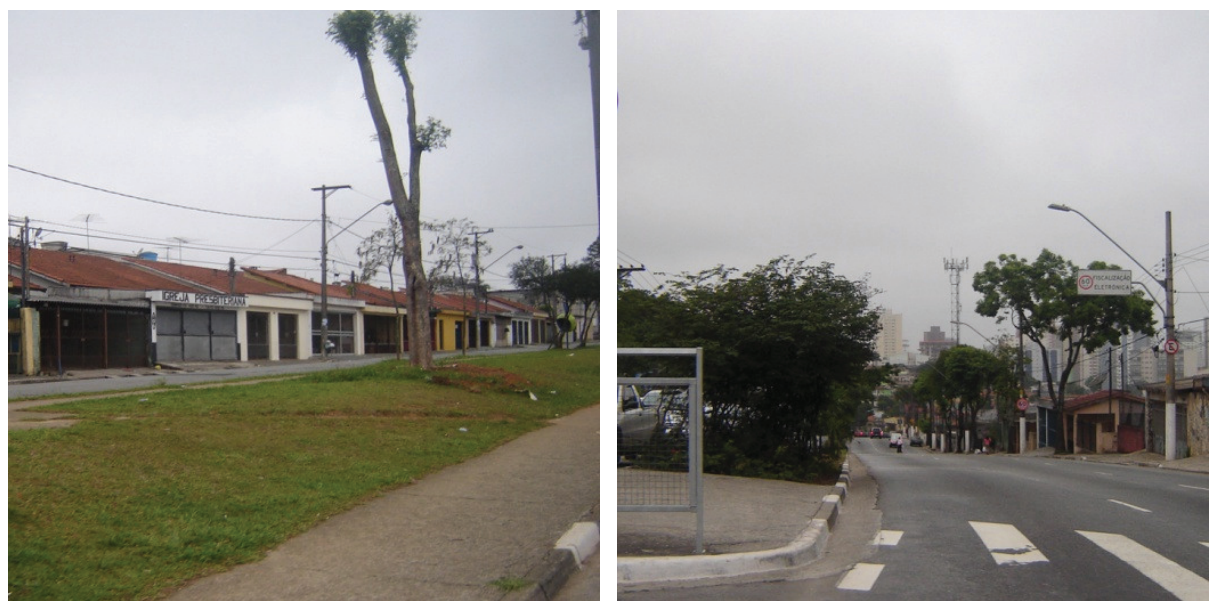

Figuras 22 e 23: eixo da Avenida Prestes Maia Fonte: Projeto MEGA, 2007. 

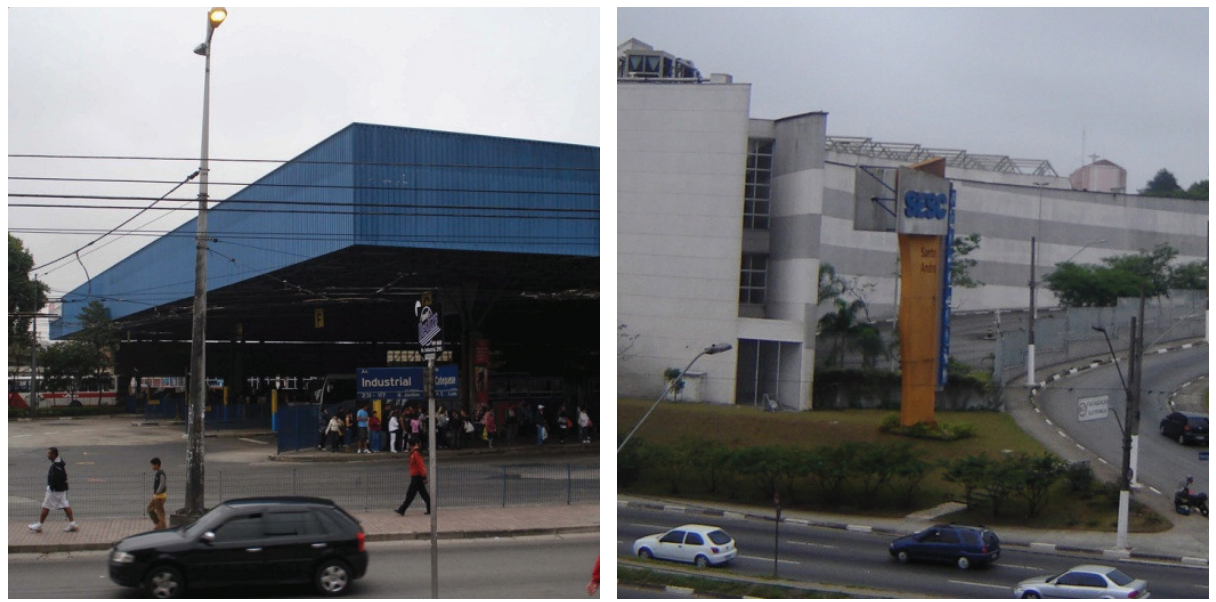

Figuras 24 e 25: Estação Santo André e SESC Fonte: Bozeda, 2010.
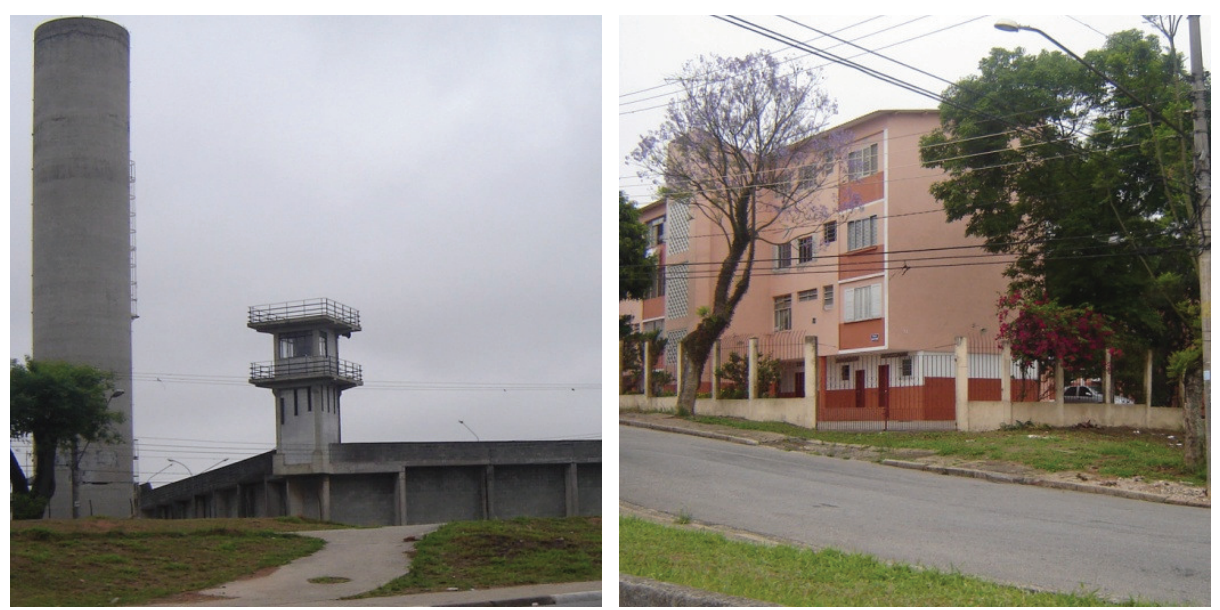

Figuras 26 e 27: presídio (esq.) e Condomínio Prestes Maia (dir.) Fonte: Projeto MEGA, 2007.
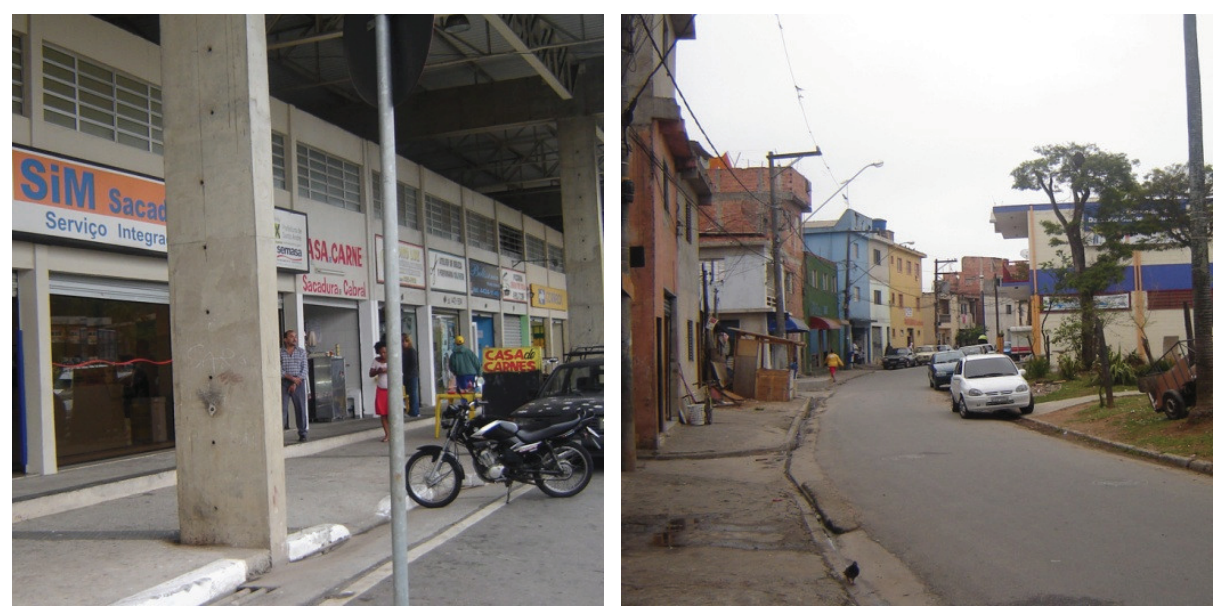

Figuras 28 e 29: Sacadura Cabral, urbanização realizada pelo Projeto SAMI Fonte: Projeto MEGA, 2007. 
Do outro lado da Av. dos Estados, na porção norte do município, encontra-se o segundo subdistrito de Santo André, o Parque das Nações [figura 30], de ocupação recente. Nesta está o bairro Capuava, próximo do pólo industrial [figura 31] que leva o seu nome, que abriga conjuntos habitacionais e lotes da prefeitura. É próximo a esta região que as famílias removidas da favela Gamboa estão sendo alocadas [figuras 32 e 33]. Nesta área do município acontece atualmente um "boom" imobiliário, verticalizado, com o surgimento de vários edifícios residenciais produzidos pelo mercado imobiliário.
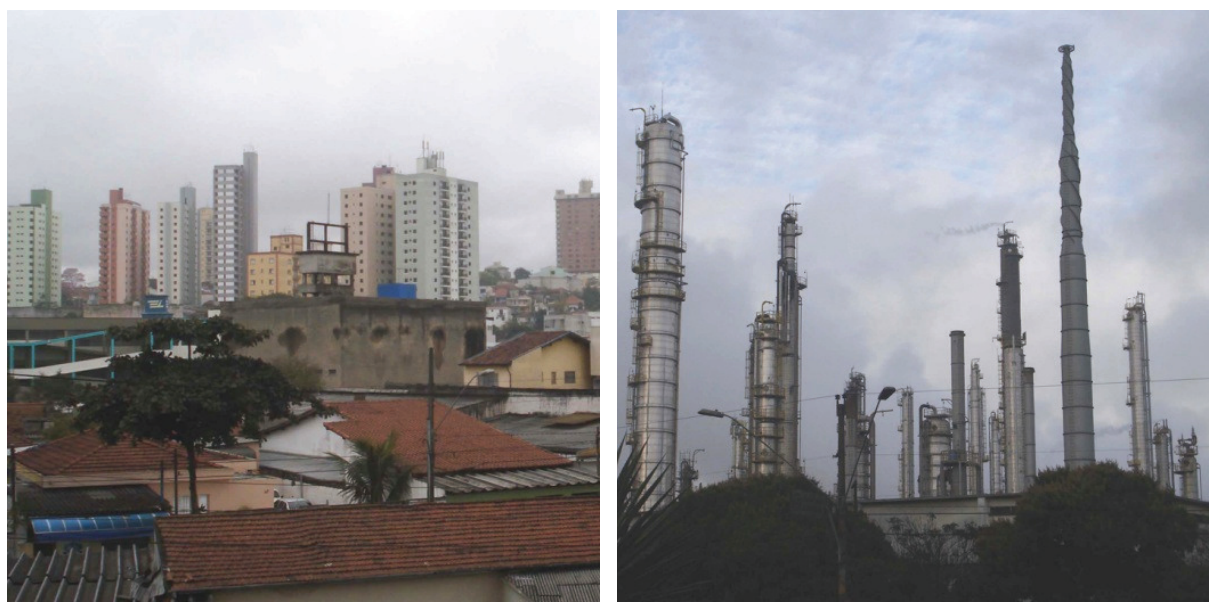

Figuras 30 e 31: Parque das Nações (esq.) e Pólo Petroquímico (dir.) Fonte: Bozeda, 2010.
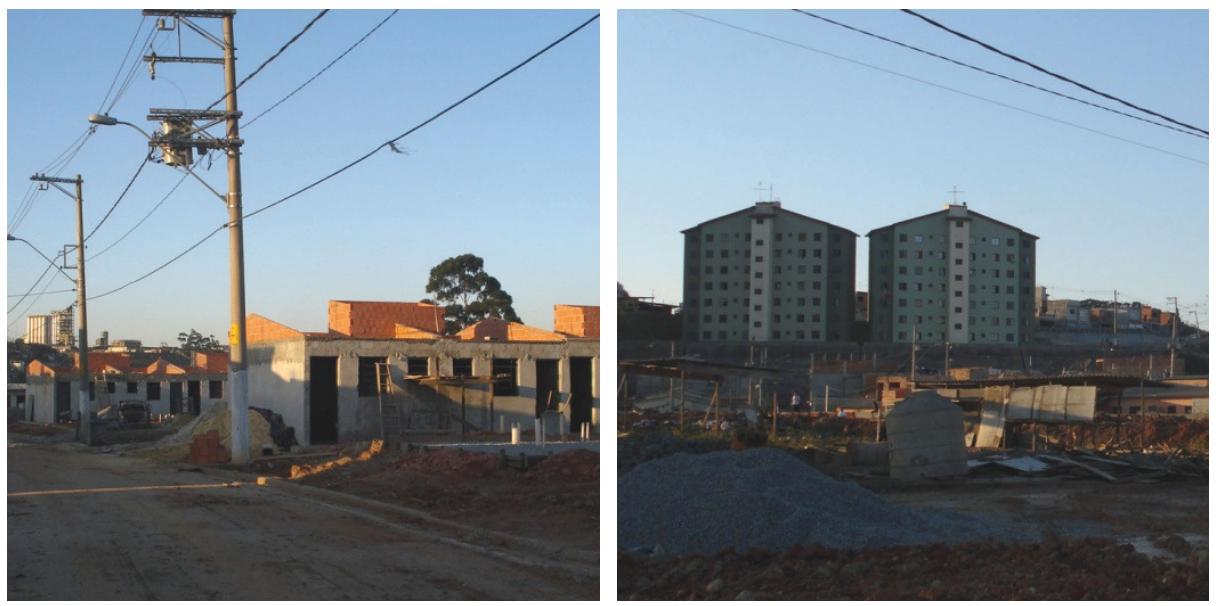

Figuras 32 e 33: conjunto habitacional Fonte: Bozeda, 2010. 


\subsubsection{A Área da Subprefeitura de Paranapiacaba e Parque Andreense}

A visita à área da Subprefeitura de Paranapiacaba e Parque Andreense (SPPA) foi realizada no primeiro semestre de 2007 com apoio da própria subprefeitura que cedeu uma van. A equipe de pesquisa foi acompanhada por uma Gerente da Subprefeitura de Paranapiacaba e Parque Andreense. Esta é a Região a sudeste do município, geograficamente apartada na mancha urbana principal pelo braço da Represa Billings, sendo uma área de Proteção e Recuperação de Mananciais [mapa 5].

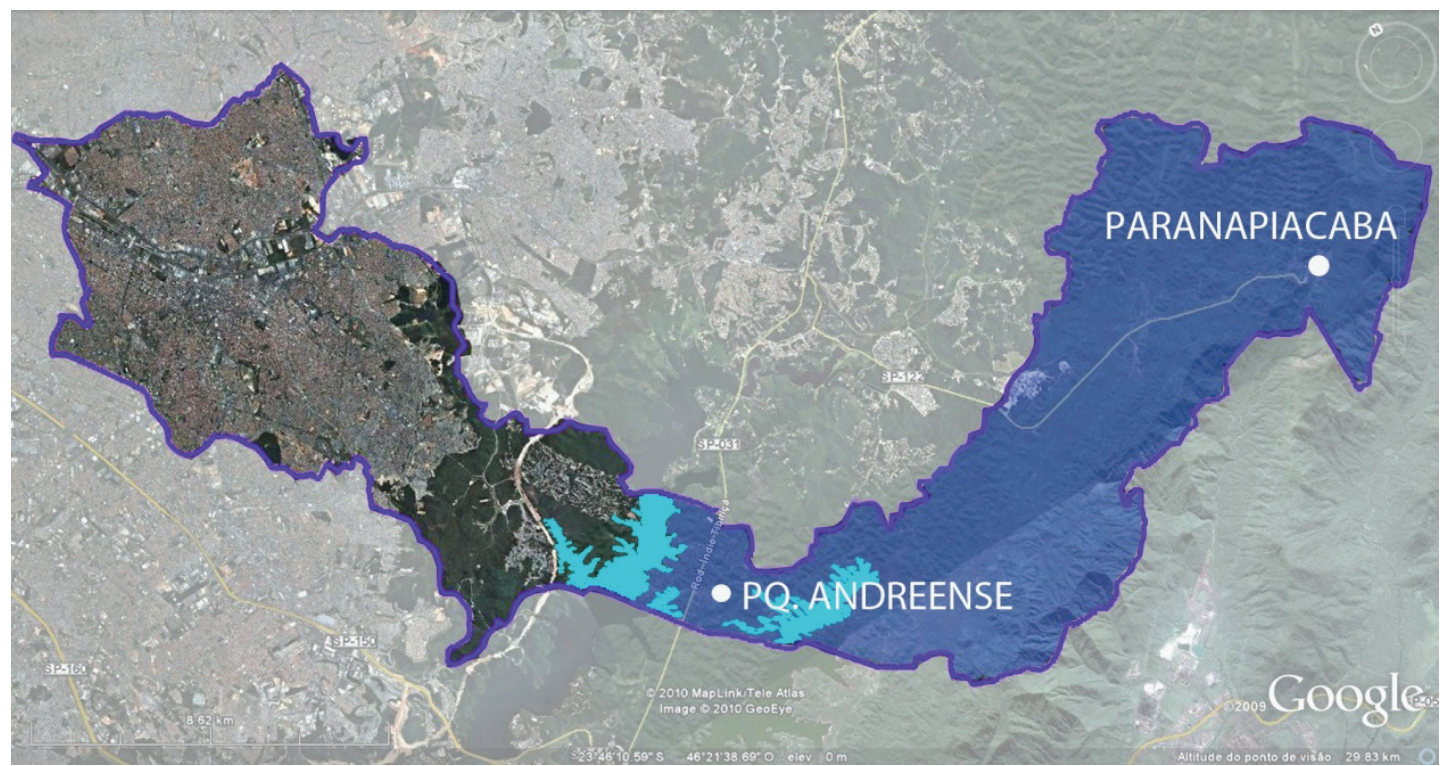

Mapa 5: SPPA - Parque Andreense e Paranapiacaba

Fonte: Preparado por esta tese a partir do Google por Bozeda, 2010.

A região da SPPA é composta por 22 loteamentos, todos aprovados entre as décadas de 1950 e 1970 pela prefeitura de Ribeirão Pires $^{35}$ e cinco núcleos de favela, dos quais quatro são muito pequenos e, por isso, são chamados de ruas. Estes loteamentos não são clandestinos, mas são irregulares, uma vez que a ocupação não condiz com o projeto, e não está de acordo com a legislação que regula a ocupação de Áreas de

${ }^{35}$ Até o final do século XX, esta área estava em disputa pelas prefeituras de Ribeirão Pires e de Santo André. Este foi um dos motivos da criação da Subprefeitura de Paranapiacaba e Parque Andreense (SPPA) e da compra da Vila de Paranapiacaba por parte da PMSA. 
Proteção dos Mananciais. A subprefeitura está trabalhando para a regularização fundiária, buscando resolver essas questões. Para evitar que as ocupações aumentem, é realizada fiscalização quinzenal em toda a área da SPPA.

Existem duas centralidades na região, a Vila de Paranapiacaba e o Parque Andreense. Nesses dois pontos se localizam as escolas e os postos de saúde que atendem toda a subprefeitura. A funcionária, que guiou esta saída a campo teve o cuidado de caracterizar a ocupação da área em quatro situações urbanas distintas:

1. Lotes pequenos: é a ocupação dos loteamentos acima mencionados, que, por terem sido demarcados de forma artesanal, resultaram em lotes grandes ao lado de lotes muito estreitos, e são objeto de projeto de regularização fundiária. Compõem este cenário as Glebas 1, 2, $3,5,15,16,17$, sendo que foram visitadas as glebas 2 e 3 .

A Gleba 2 [figuras 34 a 39] está localizada muito próxima à Represa Billings. Não há rede de água ou esgoto nesta área, que, em alguns pontos, corre a céu aberto, contribuindo para a poluição do solo e da água nesta área de mananciais. Existe sim a coleta de resíduos, que são levados para um aterro sanitário no município.
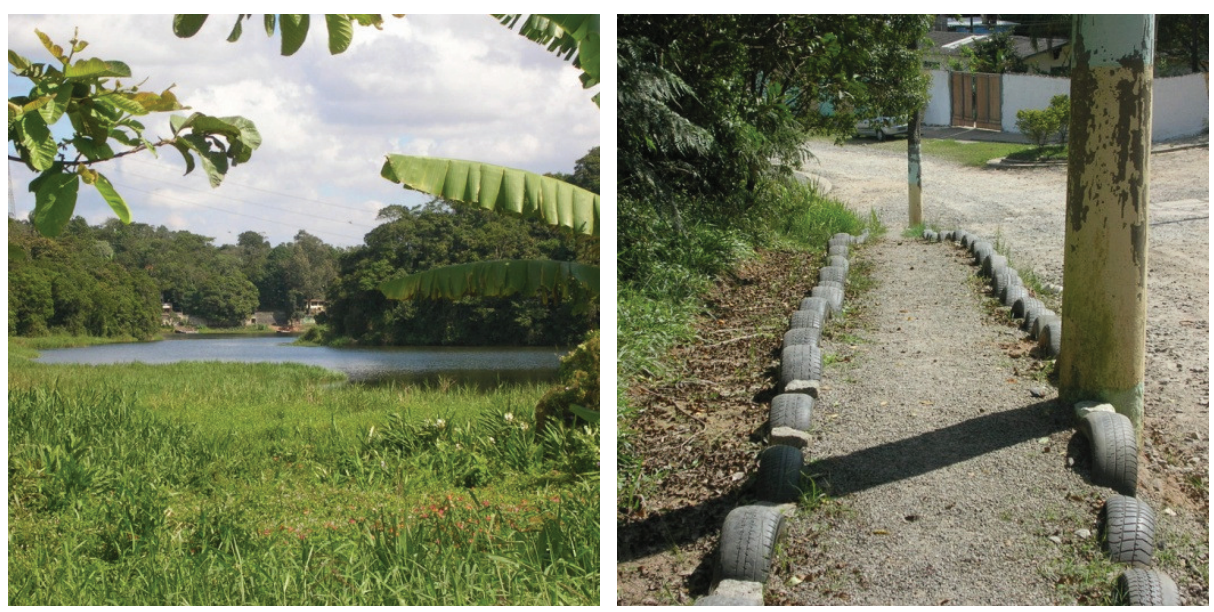

Figuras 34 e 35: Parque Andreense, Gleba 2

Fonte: Projeto MEGA, 2007. 

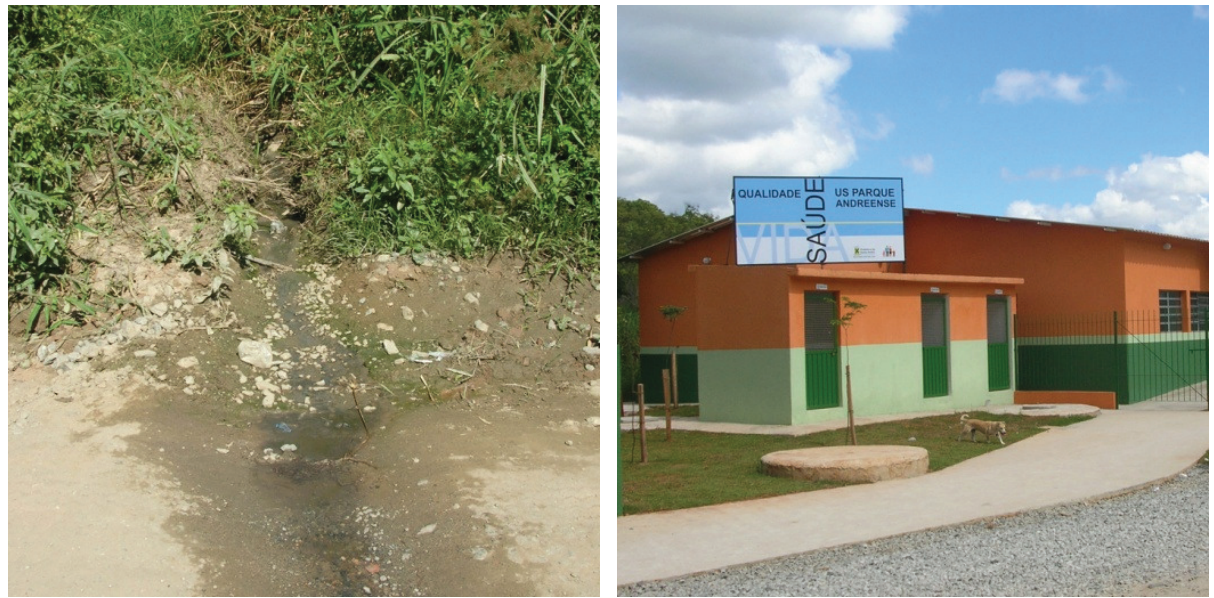

Figuras 36 e 37: Parque Andreense, Gleba 2 Fonte: Projeto MEGA, 2007.
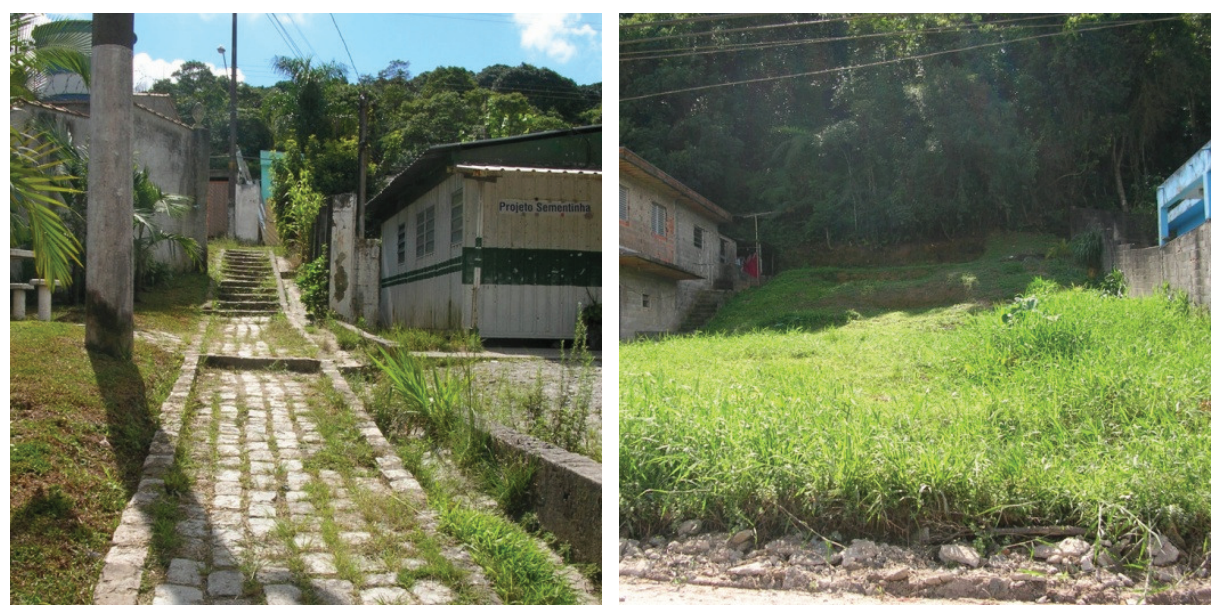

Figuras 38 e 39: Parque Andreense, Gleba 2

Fonte: Projeto MEGA, 2007.

A Gleba 3 [figuras 40 a 44] foi o local do projeto Gerenciamento Participativo de Áreas de Mananciais (GEPAM), realizado pela PMSA e a Agência Canadense para o Desenvolvimento Internacional (CIDA). Em função da existência deste projeto, alguns quarteirões foram asfaltados e as calçadas mantêm áreas gramadas para garantir a permeabilidade do solo. Nesta gleba existem ocupações diversas, como um clube de campo e um pesqueiro ou pequenas casas isoladas no morro. É aqui também que se localiza a Estação de Tratamento de Esgoto (ETE) [figura 45] que recebe efluentes de algumas residências, não atendendo toda a comunidade. 

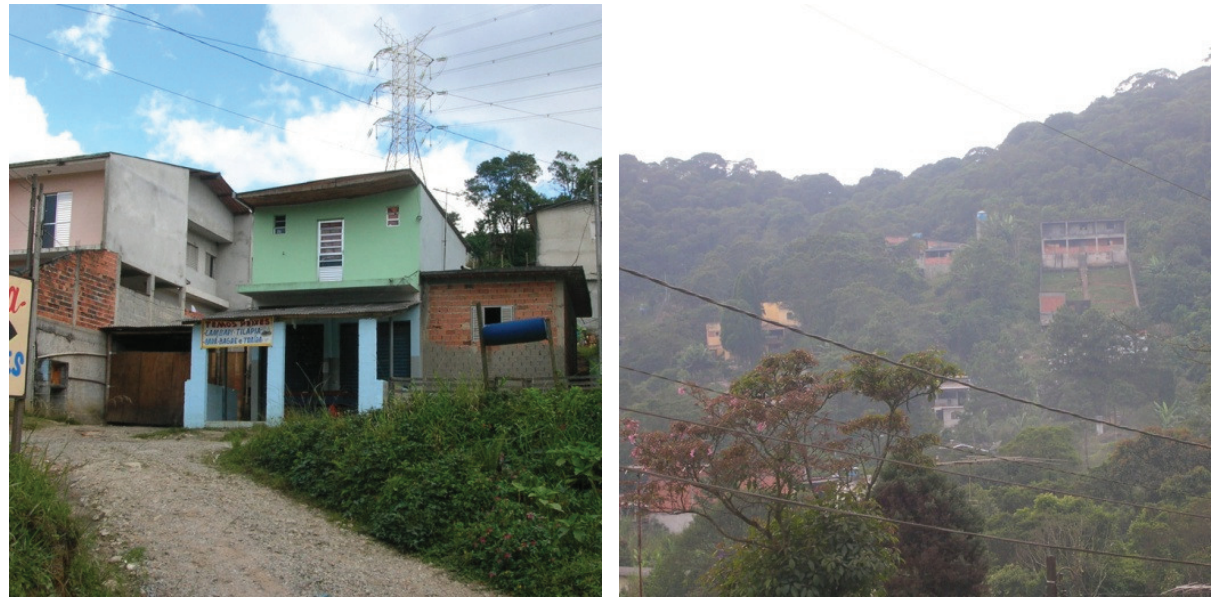

Figuras 40 e 41: Parque Andreense, Gleba 3

Fonte: Projeto MEGA, 2007.
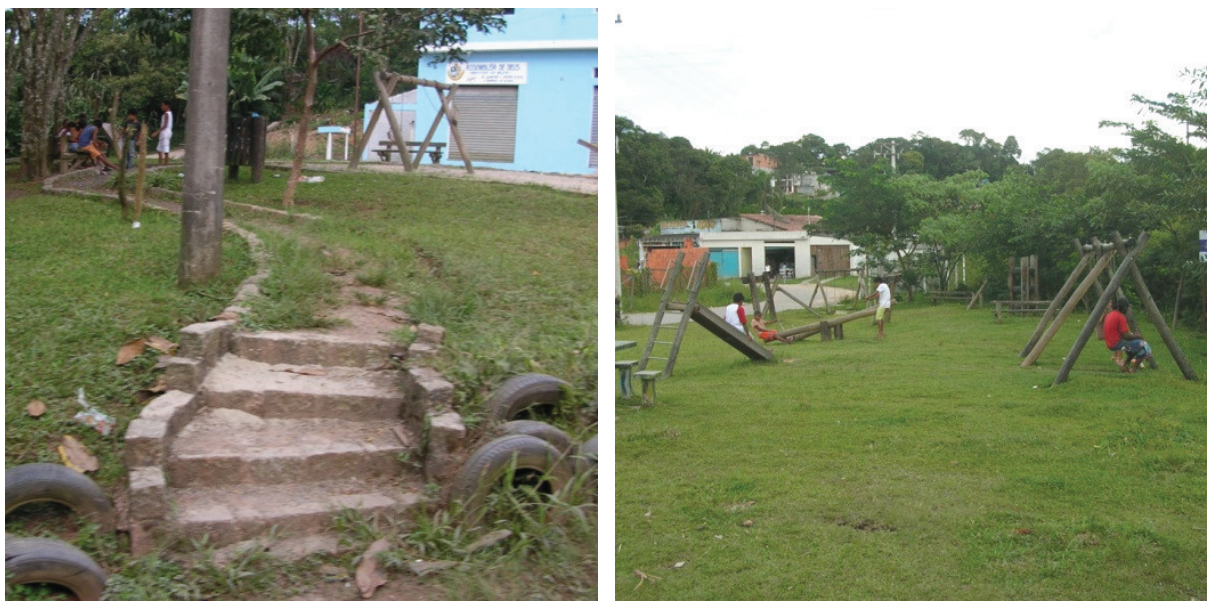

Figuras 42 e 43: Parque Andreense, Gleba 3

Fonte: Projeto MEGA, 2007.
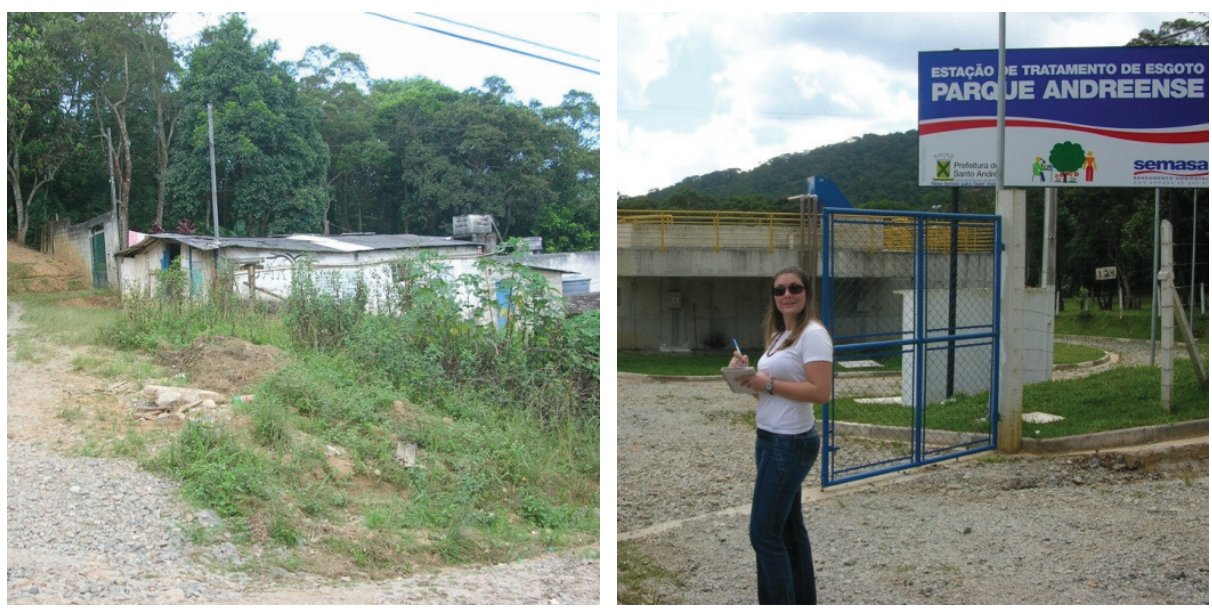

Figuras 44 e 45: Parque Andreense, Gleba 3

Fonte: Projeto MEGA, 2007. 
2. Favela: a Chácara Carreras [figuras 46 e 47] é o único núcleo que se encontra nesta situação, além das já mencionadas "ruas". A favela é conurbada com um bairro de Rio Grande da Serra e abriga 500 habitantes. Aqui não há rede de esgoto e as famílias não recebem água de caminhões pipa por não poder arcar com os custos. 0 abastecimento é feito por captação em minas ou no pequeno lago que recebe os efluentes da favela e onde as crianças brincam. A poluição resultante disto é causa de insalubridade entre os moradores da favela. A prefeitura disponibiliza transporte para as crianças irem à escola e para a utilização do posto de saúde, ambos na Vila de Paranapiacaba. A população é organizada e montou uma associação chamada AMA-Paranapiacaba.
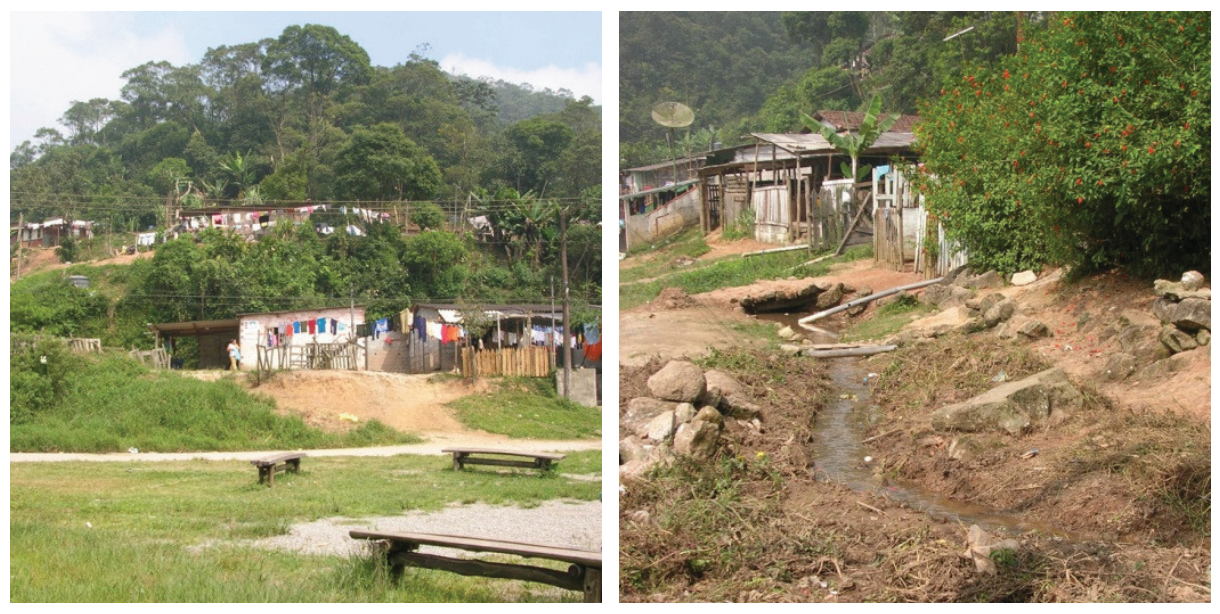

Figuras 46 e 47: Chácara Carreras

Fonte: Projeto MEGA, 2007.

3. Vila de Paranapiacaba: ocupada no final do século XIX, esta vila abrigou os operários ingleses durante a construção da ferrovia que liga São Paulo ao porto de Santos. Em 1987 os equipamentos ferroviários e a área natural de Paranapiacaba foram tombados pelo CONDEPHAAT Conselho de Defesa do Patrimônio Histórico, Artístico e Turístico do Estado de São Paulo (CIDADES HISTÓRICAS BRASILEIRAS, 2010). A PMSA adquiriu esta Vila em 2001 e procura manter suas características históricas e estimular o seu desenvolvimento apoiado no turismo histórico e natural [figuras 48 e 49]. 

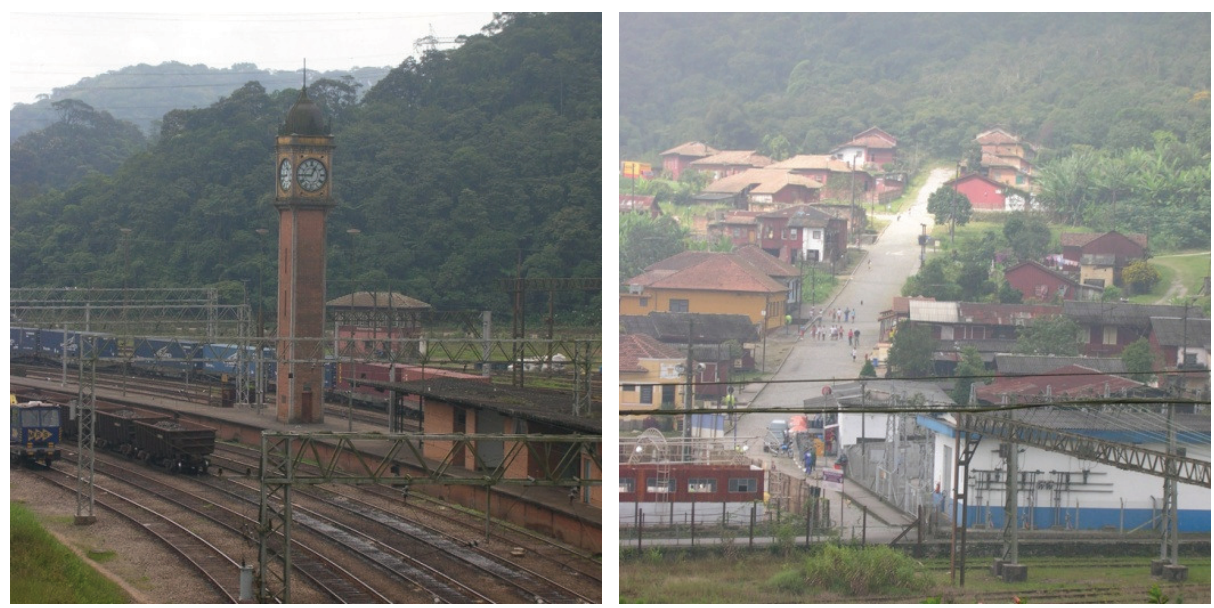

Figuras 48 e 49:Vila de Paranapiacaba Fonte: Projeto MEGA, 2007.

4. Lotes grandes ou pequenas chácaras: Este tipo de ocupação está presente no Bairro Joaquim Eugênio de Lima. São pequenas chácaras que com ocupação esparsa.

\subsubsection{Gestão Participativa}

Durante as últimas gestões, Santo André recebeu vários prêmios por resultados em políticas e inovação na administração pública, principalmente durante o governo do prefeito Celso Daniel (WAMPLER, 2007). A gestão municipal de Santo André é também reconhecida pelos acadêmicos em seus trabalhos justamente, por produzir experiências novas em políticas públicas (MELO, 1996). Celso Daniel foi uma figura muito importante no município de Santo André. Vários trabalhos acadêmicos citamno nominalmente, sempre de forma positiva. Daniel foi prefeito de Santo André pelo Partido dos Trabalhadores (PT) entre 1989-1992 e foi re-eleito em 1997-2000 e 2001, tendo sido assassinado um ano após a posse de seu terceiro mandato. No entanto, sua importância tem reflexos no processo de gestão participativa. Wampler (2007) afirma que o ex-prefeito era popular e carismático. Ele incentivou de diversas formas o engajamento direto da 
sociedade civil, empoderando o cidadão e criou novos canais de comunicação entre estado e sociedade, quebrando velhas barreiras. Massutti (2006) também atribui a Celso Daniel o início do processo participativo no município. De fato, vários projetos que remetem ao conceito de mobilização social e participação pública tiveram início na gestão de Celso Daniel entre eles, o Orçamento Participativo, o Projeto Cidade Futuro, o Projeto Integrado de Inclusão Social (PIIS) que se transformou no Santo André Mais Igual (SAMI), e os conselhos setoriais municipais.

Uma pesquisa sobre identidade do cidadão andreense, desenvolvida no final do segundo mandato de Daniel, perguntou aos cidadãos como seria Santo André se fosse uma pessoa. Como resultado obteve-se a descrição do prefeito: meia idade, engenheiro, gestor público renomado e oriundo da classe média, características do prefeito, o que denota uma liderança personalizada (MORAIS, 2004). Para Morais (2004) foram os projetos participativos que contribuíram para afirmar a identidade coletiva do cidadão andreense e para impulsionar um modelo de desenvolvimento municipal pautado na participação. Para este autor, a participação, assim como a mídia e a política urbana, pode transformar a auto-imagem do cidadão.

Apesar do grande número de experiências participativas, Santo André, assim como a maioria dos municípios latino-americanos, não tem processos sistematizados de avaliação dessas experiências. A maior parte dos estudos restringe-se a descrever as divergências entre $O$ que foi programado e aquilo que foi realizado (MENDES; BÓGUS; AKERMAN, 2004).

Os quatro conselhos setoriais pesquisados em Santo André para esta tese têm características diversas entre si. O CMPU e o COMUGESAN são conselhos setoriais de fato, pois tratam de assuntos técnicos ligados a setores administrativos da prefeitura. O CMPU trabalha com a política urbana municipal e o COMUGESAN é o conselho municipal do 
meio ambiente. Nestes dois, os assuntos técnicos preenchem a pauta e os membros, mesmo os da sociedade civil, estão, de alguma forma, ligados profissionalmente aos assuntos tratados ${ }^{36}$. Já o CMO é, na verdade, o fórum onde se realiza a etapa de tomada de decisão do Orçamento Participativo Municipal. Sua estrutura é bem diferente dos demais conselhos estudados. Para sua organização o município é dividido em 19 regiões, e os conselheiros da sociedade civil são eleitos em assembléias locais, um por região. Eles são escolhidos pela população e normalmente exercem liderança em sua comunidade, podendo ser membro de organizações da sociedade civil. 0 papel do CMO é selecionar e priorizar as diversas demandas das regiões trazidas para debate pelos conselheiros eleitos. O CRPPA também tem um aspecto territorial importante. Ele é o fórum de debate dos problemas da região da SPPA, única subprefeitura de Santo André. Como foi explicado, esta região fica geograficamente isolada do restante do município. A ocupação do território é muito diferente daquela que ocorre na parte urbana de Santo André. Aqui, a densidade é extremamente baixa e toda esta área da subprefeitura está inserida em Área de Proteção e Recuperação dos Mananciais.

Apresentam-se a seguir projetos e iniciativas participativas do governo municipal de Santo André:

Em 1997 o município de Santo André iniciou o Projeto Eixo Tamanduatehy como conseqüência de dois processos em andamento na cidade. $O$ primeiro é a articulação regional com os demais municípios do $A B C$ Paulista em que Santo André estava envolvido, buscando o planejamento urbano integrado pautado nos parâmetros do Desenvolvimento Sustentável, uma vez que grande parte do $A B C$ está em Área de Proteção e Recuperação dos Mananciais. O segundo é o envolvimento da administração municipal

\footnotetext{
${ }^{36}$ No CMPU, tem-se como participante, por exemplo, um representante do setor imobiliário e dois dos movimentos de habitação. No COMUGESAN, pode-se citar dois representantes de associações e organizações não governamentais ambientalistas.
} 
com o processo participativo do Projeto Cidade Futuro, que previa a criação de metas de desenvolvimento sustentável, e que discutiu as possibilidades de desenvolvimento em Santo André, após a grande diminuição da participação do setor secundário na economia do município (SOMEKH; CAMPOS NETO, 2005).

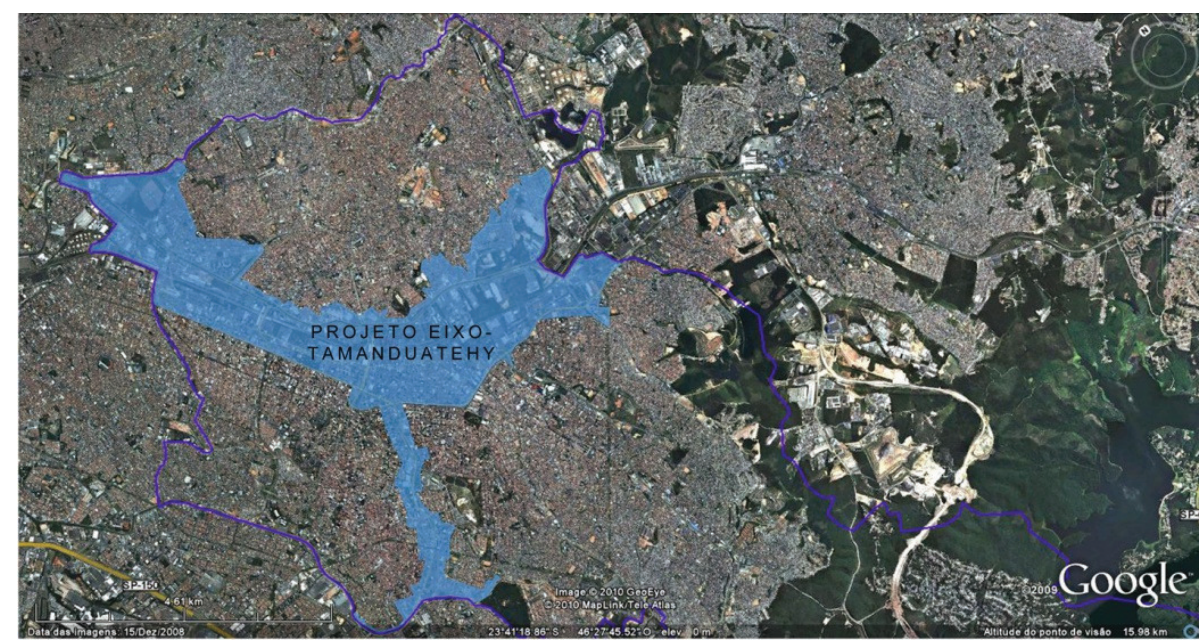

Mapa 6: área do Projeto do Eixo Tamanduatehy

Fonte: Preparado por esta tese a partir do Google por Bozeda, 2010.

A área do projeto abrange uma faixa de $8 \mathrm{Km}$ [mapa 6] que acompanha o curso do Rio Tamanduateí. Foi entre o rio e a ferrovia que se instalaram as grandes plantas industriais das quais poucas, como a Pirelli e a Rhodia, continuam em atividade. A maioria destes galpões estava abandonada, em contraste com as boas condições de acessibilidade do local, já que o rio que dá nome ao projeto é ladeado pela Avenida dos Estados que passa por São Caetano do Sul e chega em São Paulo nos bairros do Ipiranga e da Mooca (SOMEKH; CAMPOS NETO, 2005).

Este projeto foi desenhado no formato de uma operação urbana, mas com uma abertura para a participação da comunidade maior do que o previsto no Estatuto da Cidade. Neste caso, do Projeto Eixo Tamanduatehy a participação da sociedade civil foi além da representação no processo de controle da operação urbana (Artigo 33, Inciso VII do Estatuto da Cidade, BRASIL, 2001). A população participa na definição de projetos 
que a integram, muitas vezes escolhidos em ciclos de OP do município. O Projeto Eixo Tamanduatehy teve início num contexto de construção de canais participativos pelas secretarias municipais de Santo André e de processos de "participação ampliada" como o OP (SANTORO, 2005). Este projeto teve também o papel de fortalecer a gestão municipal na medida em que fomentou um processo de participação popular que se ampliou para o município através do Projeto Cidade Futuro, citado a seguir, e que se integrou com o já existente Orçamento Participativo, como, por exemplo, na aprovação do Projeto Santo André Mais Igual (SAMI), que será apresentado a seguir, e que está sendo desenvolvido na área da Operação Urbana do Eixo Tamanduateyh.

Por outro lado, o projeto não teve até 2005 um grande impacto. Embora tenha qualificado o sistema viário, teve resultados pouco integrados. Mesmo com este panorama de abertura de participação para a sociedade civil, o projeto foi pouco debatido. A causa pode ter sido o caráter não reivindicatório da participação popular, já que havia pouca população da área e poucos conflitos (SANTORO, 2005). Para Somekh e Campos Neto (2005) as dificuldades para a implementação do projeto são de ordem econômica e fundiária, mas, o mercado, que já havia se dado conta do potencial da área, já implantou shopping centers, uma universidade e um centro empresarial na região.

No que concerne à prática de discussão de projetos com a população e de canais de participativos de planejamento, o projeto teve início como Projeto Cidade Futuro, que é considerado referência para municípios e institutos que trabalham com experiências municipais. Este tipo de iniciativa tem o papel de capacitar a população para a participação na construção de políticas públicas, embora seja um processo ainda em construção. Santo André tem se mostrado um dos municípios com esta cultura participativa fortemente enraizada e muito divulgada, diferentemente da maioria dos municípios brasileiros (SANTORO, 2005). 
O Projeto Cidade Futuro teve início em 1997. No início este era o nome dado ao projeto de revitalização urbana do Eixo Tamanduatehy. Em 1999 ele mudou seu foco para que, através de um processo participativo, fossem gerados objetivos e metas de médio e longo prazo para o município de Santo André. Criou-se, no projeto, um documento chamado "Cenário para um Futuro Desejado". Como parte do projeto foi realizada uma conferência chamada de "Primeira Conferência da Cidade" em 2000. Em 2001, os grupos de trabalho já para a "Segunda Conferência da Cidade" elaboraram e aprovaram um relatório de metas e ações a serem implementadas pela administração municipal (SANTO ANDRÉ, 2009).

Morais (2004) conta que o projeto foi lançado com participação de funcionários da prefeitura, lideranças da sociedade civil e representantes de Santo André nas três instâncias do legislativo (municipal, estadual e federal). Santoro (2005) atribui ao Projeto Cidade Futuro um grande avanço no diálogo entre Estado e cidadão e a capacitação da população para discutir os problemas urbanos. Ressalta ainda que, apesar de ser um projeto em construção após anos de governos que sufocaram a manifestação cidadã, ele foi considerado referência para municípios e instituições. Ao descrever o processo do Projeto Cidade Futuro, Mendes, Bogus e Akerman (2004) ressaltam o papel do prefeito na mobilização da população para o sucesso do projeto. Além disto, tanto a criação de eventos com a participação e contribuições de consultores nacionais e internacionais quanto da inserção do Projeto Cidade Futuro no projeto Merco-Cidades ${ }^{37}$, deram a ele visibilidade, do nível regional ao internacional. Estes autores afirmam ainda que foram definidos indicadores e metas apoiadas nestes indicadores durante o processo de planejamento estratégico, visando facilitar a avaliação do trabalho como um todo.

37 O projeto Merco-Cidades é uma rede de cidades pertencentes ao Mercosul que trabalham com processos participativos para a produção de planejamento estratégico municipal. 
Caetano (2006) relaciona o projeto Santo André Projeto Cidade Futuro com Agenda 21 do município. Em 2005, após a aprovação do Plano Diretor, já em nova fase, o Projeto Cidade Futuro orientou-se para os Objetivos de Desenvolvimento do Milênio da ONU.

Em alguns pontos, o Projeto Cidade Futuro - Agenda 21 foi além da proposta oficial. Como exemplo, pode-se citar que em Santo André o processo envolveu outras instâncias de governo além do órgão ambiental, como a Secretaria de Governo e a Secretaria de Orçamento e Planejamento Participativo. Outro ponto forte do processo foi a participação dos próprios secretários no projeto. $\mathrm{O}$ assassinato do prefeito Celso Daniel e algumas inconsistências metodológicas no Projeto Cidade Futuro foram decisivos para o final da fase Agenda 21. Por esses motivos, quando houve o novo lançamento do projeto em 2005, este veio com uma proposta diferente, porém complementar à Agenda 21: os Objetivos de Desenvolvimento do Milênio.

Em 2001 foi aprovado o Estatuto da Cidade (BRASIL, 2001), lei federal 10.257, segundo o qual Santo André, entre tantos outros municípios brasileiros, deveria desenvolver o Plano Diretor Municipal através de processo participativo e aprová-lo na Câmara Municipal. A Prefeitura Municipal de Santo André apoiou-se no Santo André Projeto Cidade Futuro para a construção do Plano Diretor, uma vez que já tinham sido criadas, de forma participativa, estratégias traduzidas em metas e ações. Para seu fechamento, o Plano Diretor Municipal envolveu, ainda em processo participativo, 200 delegados eleitos representando os diversos atores, entre eles empresários, representantes de ONGs, representantes de movimentos sociais, acadêmicos, entidades técnicas e de pesquisa e administradores no município. Este plano foi aprovado e transformado em lei em 2004 (CAETANO, 2006). Gragnani (2007) também cita o Plano Diretor de Santo André como resultado de processo participativo e alinhado com o Estatuto da Cidade (BRASIL, 2001), mas não faz a ligação entre o Projeto 
Cidade Futuro e o Plano Diretor. Vale ressaltar que o Plano Diretor Municipal de Santo André ganhou um prêmio da Fundação Getúlio Vargas como uma das melhores experiências de gestão municipal ${ }^{38}$.

Outro processo participativo, entre os realizados pela prefeitura de Santo André, é o Projeto Integrado de Inclusão Social (PIIS) que em 2001 passou a se chamar Santo André Mais Igual (SAMI). O SAMI é um programa habitacional que vai além da urbanização e saneamento. Ele promove programas que buscam a autonomia da população beneficiada. No SAMI, atuam as áreas: econômica (emprego e renda), urbana (infra-estrutura e regulação fundiária) e social (como saúde, educação, cultura e assistência social) (MASSUTI, 2006).

Este projeto foi premiado por organismos nacionais $\mathrm{e}$ internacionais, como a ONU (Istambul + 5, 2001 e UN Habitat, Dubai, 2002) e Caixa Econômica Federal (MASSUTI, 2006). Contou com várias parcerias, tanto nacionais como internacionais e abriu vários canais de participação, além de englobar 11 secretarias municipais (MASSUTI, 2006). Buscou manter a população no local de origem, respeitando os vínculos sociais e, para as famílias que deveriam ser removidas buscou opções, tais como, troca de moradia, construção de apartamentos ou embriões de residência. Foram fornecidas cestas de material de construção quando aplicável (CARPIM, 2005).

O processo foi iniciado com a aprovação da demanda de urbanização da favela Capuava no orçamento participativo da cidade. Então, foram realizadas muitas assembléias. O processo foi amplamente descrito pelos autores Massuti (2006) e Carpim (2005). A abundância de reuniões e assembléias é enfatizada nas diversas descrições do projeto, assim como o papel de técnicos e agentes comunitários na comunicação, entre poder 38 Dado fornecido em entrevista com o Secretário Adjunto de Orçamento e Planejamento
Participativo de Santo André. 
público e sociedade civil e a escolha do projeto no orçamento participativo. Fica claro o caráter informativo das tantas reuniões, mas aparentemente o processo decisório está majoritariamente a cargo da prefeitura, pois não foi ressaltado nos diversos trabalhos.

É importante ressaltar que foi a expressiva participação no orçamento participativo da população interessada no projeto que viabilizou esta grande urbanização de favelas de Santo André (MASSUTI, 2006).

Santo André tem 22 conselhos setoriais (PROYECTO INCLUIR, 2006), todos em funcionamento, mas pouco foi encontrado sobre eles na literatura acadêmica. Dos conselhos analisados neste trabalho, existem estudos principalmente sobre o $\mathrm{CMO}$, que abriga o processo de OP do município e um único trabalho que menciona no CRPPA (CAETANO,2006). Além destes conselhos, menciona-se um trabalho que analisou o Conselho Municipal de Educação (CME) ${ }^{39}$.

De todos os processos participativos de Santo André, o mais estudado é sem dúvida o orçamento participativo. Talvez por isso o OP seja o mais controverso. O processo participativo do OP do município de Santo André é realizado através do Conselho Municipal de Orçamento (CMO), que tem por finalidade propor, fiscalizar e decidir sobre a utilização do Orçamento da cidade. O CMO é um conselho paritário sendo que os conselheiros da sociedade civil representam as diversas regiões da cidade.

Em Santo André, o OP teve início na gestão de 1989 a 1992, primeira gestão de Celso Daniel, quando ainda era consultivo. Voltou a existir com a volta do prefeito em 1997 passando a ser deliberativo (WAMPLER, 2007). Durante a gestão de 2005-2008 o orçamento participativo foi desenvolvido em ciclos bienais composto pelas seguintes etapas: divulgação e mobilização; reuniões e plenárias regionais; reunião de prestação de contas; posse do conselho municipal do orçamento; processo de formação

39 Que não é objeto de estudo desta tese. 
dos conselheiros; negociação; envio e aprovação da peça orçamentária na câmara municipal; execução e acompanhamento das obras e serviços; revisão do regimento interno, que proporciona oportunidade de correção de rumos pelos conselheiros experientes; discussão e preparação do OP para o ano seguinte (SANTO ANDRÉ, 2008).

Os diversos trabalhos sobre o Orçamento Participativo de Santo André parecem apontar para um processo evolutivo no que diz respeito ao caráter do conselho que evoluiu de consultivo para deliberativo. As demandas são escolhidas nas plenárias regionais. Elas são apresentadas no conselho e visitadas pelos conselheiros na "Caravana das Prioridades", onde os participantes são levados a cada uma das 19 regiões para conhecer as demandas "in loco". Só após a visita é que as demandas são priorizadas, normalmente por consenso, no conselho. Mais do que reivindicar, a população é levada a decidir através de seus representantes no conselho.

O aprimoramento do funcionamento do CMO também parece ter acontecido com relação ao atendimento das demandas. Um trabalho de 1998 aponta para a implementação de apenas 15\% das prioridades selecionadas pelos cidadãos (ZMITROWICZ; BISCARO, 1998). Outro artigo de 2007 traz números bem diferentes: 298 demandas selecionadas; 250 (84\%) atendidas, 38 (13\%) em andamento e 10 (3\%) a realizar (GRAGNANI, 2007).

Diversos artigos evidenciam o caráter social das decisões do conselho. Gragnani (2007) observa que a maioria das demandas do orçamento participativo tem cunho social. Isto seria decorrente, tanto da tradicional existência de movimentos sociais do município, quanto da melhor articulação e maior participação da população mais carente nos processos do OP.

Dois autores apresentam uma pesquisa em trabalhos distintos. Eles afirmam que quando sobrepostos os mapas de: 
vulnerabilidade social do município; níveis de investimentos realizados pelo orçamento participativo; disponibilidade de infra-estrutura; e pobreza, verifica-se que existe uma concentração de investimentos em áreas de maior vulnerabilidade social, menor infra-estrutura e maior índice de pobreza (PROYECTO INCLUIR, 2006; GRAGNANI, 2007). Esta priorização aponta para um esforço coletivo para a diminuição das desigualdades sociais. $\mathrm{O}$ trabalho do Proyecto Incluir conclui que o orçamento participativo é um poderoso instrumento de combate à exclusão social.

Os conselheiros também são muito positivos quanto ao orçamento participativo. Em entrevista na pesquisa de Massuti (2006), um conselheiro afirma que quando uma demanda é priorizada pelo OP já se pode considerar ganha. $O$ processo do orçamento participativo é valorizado e respeitado pelos conselheiros. Eles confiam na disposição do governo em dividir a responsabilidade sobre os recursos do município, criando espaço de discussão e fornecendo estrutura para que a gestão municipal seja partilhada com a sociedade. O OP possui regras claras de funcionamento que são revistas a cada ciclo, permitindo melhorias e inovações. Este processo evolutivo também atinge os membros do conselho. Freqüentemente, quando um conselheiro é eleito pela primeira vez para participar do CMO, assume a postura de procurar resolver seus próprios problemas e do seu bairro. Quando passa a conhecer o município amadurece, mudando sua postura inicial para priorizar as demandas mais necessárias, independente de estar ou não na sua região (GRAGNANI, 2007). Dois fatores que contribuem para essa mudança são: a familiaridade com a cidade, adquirida através da "Caravana das Prioridades" e a capacitação dos conselheiros no que diz respeito a leis e diretrizes orçamentárias, plano diretor e lei orgânica. Os conselheiros demonstram um forte comprometimento com o processo; valorizam a proximidade com o poder público e concordam que as regiões mais carentes do município foram privilegiadas (PROYECTO INCLUIR, 2006). 
Porém, Wampler (2007; 2008) tem dois trabalhos analisados aqui. Um capítulo de livro (2007) e um artigo (2008). Sua visão do orçamento participativo de Santo André é muito diferente dos demais textos. Para ele, embora o poder público e a sociedade civil tenham igualdade de votos, os representantes da prefeitura têm muito mais acesso à informação, mais entendimento e sabem usar melhor o poder político, além de serem mais unidos. A sociedade depende do governo para ter acesso à informação e o governo não produz uma informação relevante para tomada de decisão. Além disso, os membros da sociedade civil não têm a habilidade de argumentar contra o governo. A paridade do CMO permitiu que, na prática, o governo dominasse as decisões. Para ele, empoderamento e aprendizado público desconectados com a real delegação de autoridade são, na verdade, conceitos ocos. Wampler afirma ainda que o governo pode bloquear a agenda e que os conselheiros trabalham sob as regras do governo. $O$ autor conclui que o orçamento participativo perdeu performance porque os cidadãos não puderam tomar decisões que virassem resultados.

Um ponto importante da análise de Wampler (2007; 2008) que não foi abordado por outro autor é a falta de transparência do governo com relação ao montante disponibilizado para as decisões do OP e a porcentagem do orçamento municipal que isto representa. Para ele, o governo disponibiliza de 20 a 50\% dos gastos com novos investimentos de capital. O poder público, em entrevista para a pesquisa, argumentou que precisava ter controle sobre o restante para implementar projetos em larga escala, o que denota a pouca disponibilidade da prefeitura de Santo André em assumir os riscos políticos de cidadãos, decidindo diretamente sobre o orçamento e aponta para a necessidade de fazer reformas internas na prefeitura. Os conselheiros entrevistados acreditam ter pouco poder sobre 
recursos ou políticas públicas, o que indica que a "accountability" ${ }^{\prime \prime O}$ não está sendo ampliada.

Os textos de Wampler afirmam, em diversas ocasiões, que, o orçamento participativo de Santo André focou na mobilização e educação dos conselheiros e no desenvolvimentos dos processos de tomada de decisão, mas que ainda faltam realizações e transparência para o sucesso do OP. Wampler $(2007 ; 2008)$ observou o incômodo dos conselheiros com relação à falta de clareza sobre os valores disponíveis para atender as demandas priorizadas.

\section{O Conselho de Representantes de Paranapiacaba e} Parque Andreense (CRPPA) trabalha junto com a SPPA, que é responsável por gerir praticamente metade do território de Santo André que se encontra totalmente inserido em Área de Proteção e Recuperação dos Mananciais. Assim como os demais conselhos de Santo André, o CRPPA é paritário e deliberativo.

O conselho foi estudado por Caetano (2006). Para o autor, este tem o papel de elaborar as estratégias de gestão ambiental, patrimonial, da infra-estrutura, e o atendimento das demandas sociais da região. Caetano não chega a fazer uma análise do funcionamento do CRPPA.

$\mathrm{Na}$ busca por trabalhos que falassem dos conselhos gestores de Santo André, encontrou-se também uma análise do Conselho Municipal de Educação (CME) de Santo André (TÓTORA, CHAIA, 2002), e que foi desenvolvida através de entrevistas com seus membros. Nesta pesquisa destacam-se os seguintes achados. Apontou-se que, embora a secretaria forneça informações regularmente para apoiar a tomada de decisão, ainda existe falta de capacitação dos membros do conselho e falta de informação adequada para os trabalhos internos. Os conselheiros mostraram considerar

40 Accoutability - obrigação de um órgão administrativo prestar contas e assumir as responsabilidades pelos seus atos, sejam eles bons ou maus. Responsabilização (MELO, 2007). 
que houve um aumento de diálogo entre poder público e a sociedade e também a democratização das decisões relativas à política municipal, o que é bastante positivo. Eles apontaram também que existe abertura para que qualquer um de seus membros possa propor pauta para as reuniões. Outra conclusão foi que no $\mathrm{CME}$, a totalidade dos conselheiros do poder público apóia o governo e $67 \%$ da sociedade civil têm filiação partidária.

Quando foram perguntados sobre quais seriam os principais motivos de divergências no conselho, foram ressaltadas as discussões sobre o formato de programas e políticas públicas, o que leva a crer que estas políticas públicas são discutidas nas reuniões. Os conselheiros da sociedade civil acham que suas decisões têm influência média na secretaria. Os conselheiros da educação de Santo André afirmam que suas deliberações são executadas pela prefeitura (TÓTORA; CHAIA, 2002).

\subsection{ENTREVISTAS COM OS GESTORES DE POLÍTICAS PÚBLICAS}

$\mathrm{Na}$ fase exploratória desta pesquisa foram realizadas entrevistas em quatro secretarias ou instituições da Prefeitura Municipal de Santo André (PMSA). Buscou-se compreender como é o processo de formulação e de implementação de políticas públicas naquele município. Para tanto, foi pedido a cada secretário ou responsável pela instituição que indicasse um representante para ser entrevistado que trabalhasse diretamente com a gestão das políticas públicas.

Foram realizadas entrevistas nas seguintes instituições: Secretaria de Desenvolvimento Urbano, Secretaria de Orçamento e Planejamento Participativo, SEMASA e SPPA. Estas entrevistas seguiram um roteiro bastante completo. Na primeira parte, mais curta, buscou-se 
compreender a estrutura administrativa da instituição e quais as principais políticas públicas instituídas ou em construção. Na segunda, foi questionado o processo de formulação da política pública; e, as perguntas buscaram levantar como se dá o processo de implementação dessas políticas públicas.

As entrevistas concedidas foram longas, apresentando-se a seguir uma síntese que aborda os pontos mais importantes levantados.

A Secretaria de Orçamento e Planejamento Participativo tem uma função de apoio ao executivo e tem ligação com todas as demais instituições municipais, sendo a coordenadora do programa de governo e seus desdobramentos, planejando e organizando as ações que o compõem. Os demais instrumentos administrativos, tais como o plano plurianual e as diretrizes orçamentárias, devem se adequar às diretrizes do plano de governo. Daí advém a posição dos entrevistados em esclarecer que a autonomia é limitada. Nota-se que existe um forte alinhamento das instituições ao plano de governo, que direciona as ações de cada uma delas. Cada secretaria é responsável por detalhar suas ações e encaminhá-las ao prefeito, buscando atingir as políticas gerais. A continuidade política pela qual o município vem passando é responsável pelo funcionamento atual da gestão de políticas da prefeitura.

Pode-se notar que todos os funcionários com cargos gerenciais têm formação de nível superior em sua área de atuação, e que a escola de administração pública municipal tem um papel importante na preparação dos funcionários. Cada uma das instituições tem uma política de capacitação interna, com diferentes graus de atividade e abrangência.

As principais políticas citadas estão relacionadas com a participação popular. O OP, o CMPU, o Projeto Cidade Futuro e o Plano Diretor Municipal foram citados pelos entrevistados. O SEMASA, talvez por ser uma autarquia, tem um processo de formulação de políticas diferenciado. Utiliza o programa de qualidade da instituição, um grupo de indicadores 
estratégicos e reuniões trimestrais para monitoramento e correção de rumo. O OP é citado como fórum participativo com mais ênfase e freqüência que o COMUGESAN. O entrevistado afirma que nem tudo que é realizado na instituição precisa passar pelo conselho e que o órgão está muito envolvido com as questões de licenciamento.

A tomada de decisão é feita com dados internos, assim como dados de outras instituições, sendo que a SPPA faz pesquisas com a população, muito inferior em número que a população total do município (aproximadamente 1\%). A Secretaria de Orçamento e Planejamento Participativo foi a única que mencionou o departamento de indicadores sócio-econômicos do município.

Entre os pontos positivos mencionados pelos entrevistados pode-se destacar: a participação popular, principalmente através do OP, dado que o próprio conselho só foi mencionado pela Secretaria de Desenvolvimento Urbano e Habitação (o CMPU); o alinhamento das áreas com a política de governo; e a continuidade política. A dificuldade mais explicitada diz respeito às limitações orçamentárias que impedem que se realize todas as demandas da população.

Quanto à implementação das políticas, os entrevistados do SEMASA demonstraram dificuldades em compreender o que é uma política e como ela se materializa. Apesar de ser considerado secretaria, como eles próprios afirmaram, o SEMASA é uma autarquia, e tem um funcionamento diferenciado. Enquanto a Secretaria de Desenvolvimento Urbano e Habitação afirma que o conselho tem um papel importante e que todos elementos da política, como os planos e a legislação, passam pelo conselho (CMPU), o SEMASA afirma que após definida a política, seus componentes são definidos em reuniões de diretoria, com apoio técnico. A Secretaria de Orçamento e Planejamento Participativo e a SPPA também não citam seus conselhos quando apresentam a forma de implementação de suas políticas, porém, 
estes conselhos são espaços para discussão de demandas e monitoramento das ações públicas e não de gestão de políticas públicas como o CMPU e o COMUGESAN.

Não existe uniformidade com relação ao monitoramento do andamento das políticas. Na Secretaria de Desenvolvimento Urbano e Habitação o acompanhamento é realizado pelo conselho e no SEMASA é realizado através dos indicadores. A SPPA faz o monitoramento através do cronograma financeiro e a Secretaria de Orçamento e Planejamento Participativo diz que além do orçamento existe um acompanhamento físico das ações públicas. Os conselhos e os demais fóruns participativos são os principais canais de divulgação de políticas públicas do município.

\subsubsection{Secretaria de Desenvolvimento Urbano e Habitação}

Foi realizada entrevista com uma arquiteta, funcionária da Secretaria e conselheira do CMPU, tendo inicialmente falado do conselho e descrito sua estrutura. A seguir, sequem os resultados dos dados da entrevista expressando o ponto de vista da arquiteta.

Existe capacitação dos funcionários da secretaria decorrente da modernização administrativa que a prefeitura como um todo vem sofrendo e a escola de administração pública de Santo André tem papel importante na capacitação de seus servidores públicos.

As principais políticas públicas da secretaria são: 0 orçamento participativo, uma vez que ele é o maior provedor de demandas da secretaria; o Plano Diretor Municipal e o CMPU. As políticas públicas são criadas em função do Plano Diretor, do OP, das necessidades da cidade e do planejamento da área urbana. Os dados para a tomada de decisão vêm do Plano Diretor e de experiências de outros municípios. Alguns dados externos são necessários, como, por exemplo, do SEMASA, do Governo Federal e da 
Secretaria de Economia e Planejamento do Estado de São Paulo. A participação social é incluída no processo de formulação de políticas públicas através de audiências, conferências e conselhos. É também por esses canais de participação que é realizada a divulgação das políticas públicas, tanto durante, quanto após seu processo de elaboração. Não existe autonomia total na formulação de políticas públicas porque elas derivam de processos democráticos.

Como pontos fortes da formulação de políticas pela Secretaria de Desenvolvimento Urbano e Habitação pôde-se destacar: a gestão democrática, o orçamento participativo, os conselhos e a legislação. As dificuldades ficam por conta das limitações orçamentárias e da legislação, que às vezes dá margem a interpretações distintas; da falta de capacidade de atender à demandada dos processos participativos e da desorganização da população. O processo de formulação de políticas é quase sempre transparente.

Quanto ao processo de implementação das políticas públicas formuladas, é preciso entender que, no OP, é realizada a parte orçamentária em um ano e no ano seguinte é feito o planejamento estratégico. O conselho tem um papel importante nesta etapa da gestão. Com relação à política urbana, tudo passa por ele, tanto a legislação urbana, quanto planos, como, por exemplo, o plano de habitação. A secretaria tem a tarefa de orientar os conselheiros para tomada de decisão, porque nem todos são técnicos da área.

Para a tomada de decisão, eles se apóiam em dados do orçamento participativo, onde as prioridades são elencadas pela população. A variável ambiental é sempre considerada. Se determinado projeto não estiver de acordo com as normas ambientais o SEMASA não aprova; então, não haveria forma de desconsiderar o meio ambiente. 
A secretaria trabalha constantemente em captação de recursos humanos e segue o trâmite geral para ajustes no orçamento. 0 monitoramento do andamento das políticas públicas é de competência do conselho. Em Santo André existe a cultura da população cobrar a prefeitura no cumprimento de promessas. Além do conselho e da própria população, a ouvidoria funciona como canal de cobrança. O acompanhamento é constante, e as informações derivadas do monitoramento interferem no rumo das políticas, que quase sempre caminham de acordo com os prazos estabelecidos e são implementadas até a obtenção dos resultados propostos.

A população deveria saber o que está sendo feito e os resultados parciais das políticas são parcamente divulgados. A divulgação é feita através dos conselhos, publicações oficiais e pelo departamento de comunicação da prefeitura e, na maioria das vezes só acontece quando o projeto está concluído.

Os pontos fortes do processo de implementação de políticas são: o pioneirismo do município em relação à aplicação dos instrumentos do Estatuto da Cidade; a seriedade com que se trabalha, pois, quando assumida uma demanda, ela é desenvolvida até sua conclusão; a participação e a transparência. Uma das dificuldades encontradas acontece pelo fato de Santo André ser pioneiro, existindo dificuldade em encontrar experiências para servir de base para a atuação municipal, principalmente experiências em municípios com características similares à Santo André. Vale ressaltar que, em função do pioneirismo, a Prefeitura Municipal de Santo André é muito consultada por outros gestores municipais. Outra dificuldade decorre da burocracia que às vezes atravanca os projetos. Ainda como dificuldade tem-se a legislação nos diversos níveis de governo sendo muito restritiva, o que torna difícil, por exemplo, aplicar as exigências de acessibilidade numa situação de núcleo habitacional em um morro. Por fim, cita a falta de retorno da população com relação aos projetos implantados. 
O processo de implementação de políticas é sempre transparente e existem muitas políticas públicas multissetoriais no município que envolvem a Secretaria de Desenvolvimento Urbano e Habitação.

\subsubsection{SEMASA}

A entrevista com os representantes do SEMASA foi aplicada na própria instituição e o seu superintendente foi assessorado por outros dois funcionários. Antes de apresentar a conversa com esse representante cabe trazer uma observação feita pelo próprio entrevistado sobre o SEMASA.

\footnotetext{
"O SEMASA, apesar de ser uma autarquia, na estrutura administrativa da prefeitura é considerado uma secretaria. Não no sentido financeiro, porque no financeiro e administrativo é diferenciado, mas em termos de participação. Reunião de secretariado, toda a quintafeira às 8 h00 da manhã, o superintendente está lá."
}

Os dados apresentados a seguir são resultado da entrevista e estão expressos sob o ponto de vista dos entrevistados.

Todos os cargos de gerência do SEMASA, assim como os superiores aos gerentes, são ocupados por funcionários com nível superior. Existe dentro da instituição um plano anual de treinamento que promove educação para os demais funcionários, desde a alfabetização, ministrada por funcionários do próprio SEMASA, até o ensino médio.

A formulação de políticas públicas na instituição segue 0 Plano de Governo proposto, as demandas aprovadas no OP e o planejamento estratégico da própria instituição. Estas são as três linhas mestras que definem as ações e o orçamento, além de impor os limites. Existem demandas que apenas o SEMASA conhece, como a reforma de um reservatório, por exemplo. Quando questionado sobre o processo de 
formulação de políticas públicas, o entrevistado afirma que ele tem estreita ligação com o programa de qualidade do SEMASA. Existem reuniões trimestrais fora da autarquia que reúnem 25 pessoas entre diretores, coordenadores e assessores de diretoria, assim como o superintendente. Nessas reuniões são revistas e discutidas as políticas e programadas ações corretivas. O SEMASA trabalha com indicadores, sendo que 21 deles são estratégicos e sendo trabalhados nessas reuniões. Como apoio à tomada de decisão, citam-se novamente o Plano de Governo, as demandas do OP e o Plano Estratégico da instituição. Foi perguntado se as metas do Projeto Cidade Futuro eram consideradas na formulação de políticas da instituição. Neste momento da entrevista, o documento foi incluído entre aqueles que dão suporte à tomada de decisão.

Com relação aos mecanismos de participação social, o orçamento participativo foi o primeiro fórum de participação lembrado, e considerado o mais importante. O COMUGESAN foi descrito logo em seguida como acolhendo representantes de instituições importantes.

\section{"Este conselho também define algumas diretrizes. Algumas tomadas de decisão também são submetidas a este conselho. Ele é um conselho deliberativo [...], entretanto [...] para eu fazer uma obra nem sempre preciso perguntar para o conselho se pode [...]."}

Todos os planos foram apresentados para o conselho e os conselheiros têm consciência de como o SEMASA funciona. O conselho é muito demandado na questão do licenciamento ambiental e são responsáveis por certas tomadas de decisão.

Determinadas políticas públicas passam por audiências antes de serem apresentadas para a Câmara e não existe procedimento padronizado para divulgar as políticas aprovadas. Algumas incluem campanhas, como a de coleta seletiva. Neste caso, a população é informada e chamada a participar. Os funcionários de caráter técnico do SEMASA são os 
responsáveis por apoiar o delineamento das políticas. Em casos específicos pode haver a contratação de profissionais para dar suporte.

Quanto ao grau de autonomia da instituição pode-se ressaltar que autonomia é diferente de independência. A instituição que participa de uma administração, está ligada à política de seu governo e às demandas do OP. O atual processo de formulação de políticas em Santo André foi sendo desenvolvido com a continuidade administrativa sendo um modelo respeitado e seguido por muitos. Como pontos positivos do processo de formulação de políticas foram citados: o orçamento bem elaborado; a matricialidade com as outras secretarias; o orçamento participativo; o plano de gestão da qualidade; que busca melhoria contínua; a existência de indicadores; e um sistema de georreferenciamento na instituição. Como dificuldades citou-se: a incapacidade de se realizar tudo o que se tem vontade de fazer; a matricialidade que traz demandas; e as necessidades técnicas em contraposição com as necessidades políticas. O processo de formulação de políticas na instituição é quase sempre transparente.

Antes dos entrevistados se sentirem aptos a conversar sobre as características do processo de implementação de políticas públicas de Santo André, houve uma conversa de ajuste de vocabulário e de conceitos entre a equipe de pesquisadores e os entrevistados.

Após definida uma política, seus componentes são definidos em reuniões de diretoria com apoio técnico. O monitoramento é feito através de indicadores do programa de qualidade, indicadores de resultado, e não de ações. E as mesmas são avaliadas pelos resultados. O monitoramento é realizado mensalmente. Os indicadores, em alguns casos, são avaliados diariamente, como os de qualidade da água; uns mensalmente; e outros trimestralmente. As informações do monitoramento interferem totalmente no andamento da política, pois geram os planos de ação. 
As políticas costumam caminhar quase sempre de acordo com os prazos estabelecidos. Quase sempre alcançam os resultados propostos e os resultados parciais são divulgados para o cidadão, inclusive através do COMUGESAN, por meio de entrevistas e reportagens.

O pontos fortes do processo de implementação das políticas públicas são: o monitoramento constante; os conselhos municipais; a matricialidade do governo; a visão de processo; a existência de recursos financeiros. As principais dificuldades são: compatibilizar as demandas das secretarias; a participação, que é o caminho mais interessante, porém mais trabalhoso; o contexto metropolitano que torna mais complexa a gestão do saneamento e a qualidade do ar.

O processo de implementação das políticas é quase sempre transparente. Existem várias políticas multissetoriais com as secretarias de habitação, inclusão social, educação ambiental, saúde pública, além da SABESP, CETESB e Secretaria Estadual do Meio Ambiente.

\subsubsection{Secretaria de Orçamento e Planejamento Participativo}

A entrevista teve início com a explicação, por parte do representante, sobre o funcionamento da secretaria. Por não se tratar de uma secretaria setorial, e sim de uma instituição voltada para as políticas de governo, esta secretaria trabalha com o poder público como um todo e tem uma função transversal. Os dados apresentados a seguir são resultado da entrevista e estão expressos sob o ponto de vista do entrevistado.

A atribuição da secretaria é planejar e organizar as atividades e ações que o governo desenvolve. Eles coordenam o processo de orçamento participativo em Santo André, que é uma importante política de governo. As políticas municipais como um todo, respeitam o programa de governo do prefeito, utilizado no processo eleitoral. No mandado em vigor, 
por exemplo, existem cinco diretrizes que norteiam todas as ações e políticas: educação e identidade cultural; inclusão social; desenvolvimento urbano e ambiental; participação cidadã e modernização e desenvolvimento econômico.

Segue-se então a legislação e formulam-se os instrumentos administrativos. O plano plurianual engloba quatro anos administrativos e entra em vigor no segundo ano de mandato do prefeito eleito, o que significa que, no primeiro ano do mandato seguinte, ainda estará em vigor. Neste plano é definido tudo o que é novo, as políticas que serão implementadas e os novos projetos. O detalhamento deste plano é feito na lei de diretrizes orçamentárias. O orçamento participativo é um dos elementos da diretriz de participação cidadã e modernização, sob responsabilidade da secretaria, onde são definidas as prioridades para saúde, meio ambiente, habitação, e as demais áreas, e que está em seu $11^{\circ}$ ano de funcionamento. Ainda como elemento desta diretriz de participação cidadã, falou-se dos $21^{41}$ conselhos municipais nas mais diferentes áreas.

Os gerentes e os diretores da Secretaria têm nível universitário condizente com a sua área de atuação. Existe uma política de capacitação de funcionários que, tanto forma as pessoas em sua área de trabalho, quanto em ferramentas gerais da prefeitura, tais como softwares de acompanhamento de projetos.

Como apoio à tomada de decisão foram citados: a viabilidade da ação; o público atingido; a disponibilidade de recursos financeiros, técnicos e operacionais; e a inserção nas diretrizes de governo enumeradas anteriormente. Como fonte de dados para esta tomada de decisão apontouse: o departamento de indicadores sócio-econômicos e o sumário de dados produzido por este departamento. Foi também mencionado o controle

${ }^{41}$ Este número diverge do número adotado pela equipe de pesquisa, pois, durante o andamento do projeto MEGA e desta tese foram criados e modificados conselhos, o que fez com que este valor oscilasse. 
gerencial financeiro e de orçamento e os observatórios existentes em algumas secretarias. O Projeto Cidade Futuro é um elemento que faz parte deste processo como planejamento a longo prazo incluído, na diretriz de participação cidadã, mas só foi citado quando questionado diretamente sobre seu papel na gestão.

Existe uma relação entre participação social e formulação de políticas públicas que foi ressaltada com a participação dos conselhos, audiências para a apresentação das políticas e a formulação de estratégias como o próprio Projeto Cidade Futuro, que alimentou o Plano Diretor Municipal e que atualmente envolve o CMPU na formulação os planos setoriais, como habitação, uso do solo, patrimônio, mobilidade urbana, entre outros. O Plano Diretor Municipal de Santo André ganhou um prêmio na Fundação Getúlio Vargas como uma das melhores experiências de gestão municipal. Como o debate foi desenvolvido com a sociedade civil, a aprovação da sociedade se dá no processo de formulação destas políticas. A divulgação para a sociedade das políticas formuladas acontece através de relatórios, outdoors, do CMO e de publicações, como a revista dos 10 anos do orçamento participativo.

Para a formulação das políticas públicas no município utilizase o pessoal técnico das próprias secretarias, raramente precisando recorrer a pessoas contratadas especificamente para esse fim. Esta forma de se estabelecer as políticas municipais decorre da continuidade política. É a quarta administração do PT no município, sendo a terceira seguida e o processo vem sendo aprimorado. Os pontos fortes do processo de formulação de políticas são: a existência de um planejamento estratégico, a participação da população, o comprometimento das áreas com a política central do governo, o respeito que as áreas têm ao planejado e o foco na política. Por outro lado, só foi identificada uma dificuldade no processo: conciliar as diferentes formações dos gestores, que podem ser médicos, arquitetos, administradores, dependendo de sua função. Ressaltou-se que, 
como existem regras claras pré-estabelecidas, as pessoas as respeitam e isto ajuda a diminuir as dificuldades. $O$ entrevistado considera que o processo de formulação de políticas no município é transparente.

Foi ressaltado que, quando se inicia um mandato, ainda está em vigor o plano plurianual da gestão anterior. Se não fosse uma continuação de gestão, como o que vem acontecendo em Santo André nas últimas eleições, seriam feitas modificações neste plano para dar início à nova política. Ainda no primeiro ano de governo é realizado o detalhamento das políticas. Na administração pública tudo passa pelo orçamento e se não estiver previsto no orçamento, nada pode acontecer. O planejamento não é estático e, se houver necessidade de alterações identificadas através do monitoramento, é possível realizar ajustes. O monitoramento da execução dos planos, programas e projetos é realizado dentro do planejamento de orçamento, tanto financeiramente quando fisicamente. Os projetos, quando são criados, são cadastrados num sistema que permite acompanhamento, realizado semanalmente. As políticas, às vezes, andam de acordo com o cronograma e quase sempre são implementadas até a conclusão. Os resultados parciais das políticas, assim como seu andamento, são divulgados com freqüência através das plenárias e o responsável por essa divulgação é o próprio prefeito.

Como pontos fortes do processo de implementação de políticas públicas foram citados os mesmos do processo de formulação, que são: a existência de um planejamento estratégico; a participação da população; o comprometimento das áreas com a política central do governo; o respeito que as áreas têm ao planejado; e o foco na política. Como dificuldade, foram apontadas: a eventual falta de detalhamento de projetos pelas secretarias; e a subestimação dos recursos necessários para sua execução. 
O processo de implementação de políticas é sempre transparente e, por ser uma secretaria de caráter administrativo e transversal, sempre trabalha em conjunto com as outras instituições da administração pública municipal.

\subsubsection{Subprefeitura de Paranapiacaba e Parque Andreense}

A entrevista foi realizada com o representante que iniciou apresentando a estrutura da instituição, com seus três departamentos administrativos. Seguem abaixo os resultados da entrevista expressos sob o ponto de vista do entrevistado.

O planejamento da subprefeitura é realizado no início do mandato e reavaliado anualmente. Todos os funcionários a partir do nível de gerência têm formação com nível superior, e a formação predominante é a de biólogo. A prefeitura tem uma escola de formação de administração pública que é uma escola geral que dá cursos de atendimento ao público. A subprefeitura tem uma prática de estímulo à pós-graduação e à participação em seminários relacionados às atividades da instituição, principalmente quando acontecem em São Paulo, pela proximidade.

O processo de planejamento do município é decorrente do plano de governo do prefeito eleito, e do planejamento estratégico como resultado desse plano. Todas as secretarias desenvolvem atividades de planejamento seguidas dos detalhamentos setoriais e da compatibilização com o orçamento público. Os dados para a tomada de decisão são: dados prontos da própria instituição; dados preparados na instituição para apoiar uma determinada tomada de decisão; dados levantados especificamente para cada política; e, também dados que vêm de outras instituições. Isto além de pesquisa com a população. 
As políticas existentes são consideradas quando da formulação de novas políticas, como no exemplo o Projeto Cidade Futuro, onde se trabalha com uma perspectiva de 15 a 20 anos. Pode-se exemplificar com o viaduto Cassaquera que está sendo construído e que está inserido em uma estratégia para estimular as indústrias já previsto há oito anos.

Os conselhos, o orçamento participativo, a participação dos membros do partido na elaboração do plano de governo e sua aprovação através do processo eleitoral são canais de participação da população no processo de formulação de políticas públicas. O OP é um exemplo de política pública que passa por aprovação social antes de ir para a câmara municipal para aprovação. Quanto à divulgação das políticas, pode-se citar o Projeto Cidade Futuro e o OP como políticas amplamente divulgadas, em contrapartida ao plano estratégico da prefeitura, que não é levado ao conhecimento da população. O que tem mais divulgação é o orçamento participativo. Para a formulação das políticas são utilizados os próprios técnicos da prefeitura. Existem algumas situações especiais em que não há pessoal suficiente ou que se necessita de alguma "expertise" que não está disponível internamente e, então, se contrata pessoal externo. Esse foi o caso do projeto do Eixo Tamanduatehy.

Existe uma amarração entre as ações da instituição e a política do governo. Cabe às instituições detalhar as ações para atingir as políticas e submetê-las ao prefeito. A autonomia das áreas acontece no sentido de indicar as ações para atingir as metas políticas e submeter ao prefeito. O governo definiu determinada meta e a subprefeitura se organiza para cumpri-la.

Os pontos fortes do processo de formulação de políticas públicas são: o planejamento orçamentário; a capacidade técnica da instituição; a continuidade do governo; a participação da sociedade; e a 
facilidade de relacionamento com o governo federal. As dificuldades são: a falta de recursos financeiros; as dificuldades na relação com os órgãos estaduais; e, às vezes, dificuldades na relação com as prefeituras vizinhas. $\mathrm{O}$ processo de formulação de políticas é quase sempre transparente.

A implementação de políticas públicas segue o seguinte processo. Primeiramente é realizado um planejamento onde fica claro para as áreas quais são as suas tarefas, seguido do desdobramento dessas ações. O plano de governo repercute na área em determinadas ações e planeja com a área como realizar o plano. É feito um planejamento no início do governo que é revisto anualmente. As correções são conversadas com o corpo técnico e quem toma a decisão final, na maioria das vezes é o secretário. Se o assunto for relevante há uma consulta anterior ao Prefeito. As decisões são sempre tomadas de acordo com o plano de governo e são priorizadas através de uma avaliação estratégica para que se consiga cumprir o plano de governo. O entrevistado explicitou uma preocupação com questões como a regulação fundiária, que está sendo tratada pela subprefeitura neste momento. Em uma troca de gestão, os técnicos terão muito trabalho para convencer o novo gestor a dar continuidade ao processo. Esta é uma situação onde o conhecimento acumulado por anos de trabalho no local se perde quando há troca de gestores.

Na subprefeitura, a variável ambiental é o ponto de partida para a tomada de decisão. Vale lembrar que a estrutura da subprefeitura foi, inicialmente, derivada do SEMASA, autarquia que trabalha com a gestão ambiental no município.

A distribuição de verbas é realizada pelo planejamento do governo, onde a prefeitura designa um montante negociável para cada setor. Os reajustes são feitos a cada reavaliação do planejamento, que é anual, ou sempre que necessário. Existe um funcionário que é o agente de planejamento que monitora diariamente os programas através do 
cronograma financeiro. Quase sempre as políticas caminham de acordo com o cronograma e sempre são realizadas até sua conclusão, porém, só às vezes é que são divulgadas para a comunidade. Os conselhos são o principal meio de divulgação. São realizadas também algumas publicações e matérias de jornal. Essa divulgação de resultados é feita algumas vezes pela própria subprefeitura, outras pela Secretaria de Comunicação.

Os pontos fortes do processo de implementação de políticas no município são: a continuidade administrativa; a qualidade técnica dos profissionais; o bom desempenho orçamentário; e a inter-relação com o conselho. As principais dificuldades são: o relacionamento com órgãos do estado e com algumas das prefeituras vizinhas; a desarticulação das prefeituras para tomada de decisão conjunta; e o excesso de tarefas para serem realizadas ao mesmo tempo. 0 processo de implementação de políticas foi considerado quase sempre transparente.

Existem vária políticas multissetoriais. Algumas citadas foram a de capacitação de moradores realizada com a secretaria de educação e com a secretaria de desenvolvimento e ação social e o licenciamento ambiental que é realizado junto com o SEMASA.

\subsection{A REGULAMENTAÇÃO DOS CONSELHOS}

A Lei Orgânica de Santo André foi aprovada em 02 de abril de 1990 (SANTO ANDRÉ, 1990), dois anos após a constituição nacional. Este documento afirma que a participação da população através dos conselhos é uma das formas de gestão democrática do município. Estes conselhos estão tecnicamente vinculados ao executivo municipal, que, junto com o legislativo, garantirão as informações e os espaços para seu funcionamento. 
Os conselhos são paritários entre representantes do poder público e da sociedade civil organizada. O mandato é de no máximo dois anos, sendo permitida uma reeleição, e os conselheiros não podem ser remunerados. Porém só estão sujeitos a mandato os conselheiros da sociedade civil. Os membros do poder público são nomeados pelo executivo e não têm mandato estabelecido. É admitida, porém, a troca dos representantes do poder público pelo prefeito quando este assume o cargo. Os poderes executivo e legislativo são os responsáveis, pelo cadastro das entidades interessadas em participar dos conselhos e não podem vetar a participação de nenhuma empresa que manifeste interesse em tomar parte do processo. Cada conselho deverá promover no mínimo uma plenária aberta à participação de todos os cidadãos.

Já na Lei Orgânica Municipal são criados três dos quatro conselhos estudados: o CMPU (que na Lei orgânica ainda é o Conselho Municipal de Desenvolvimento Urbano), o COMUGESAN e o CMO, a serem regulados por leis específicas. Destes, apenas o CMPU e o COMUGESAN foram efetivamente regulamentados por lei. O CMO e o CRPPA seguem apenas seu regimento interno. Dos quatro conselhos estudados, três (COMUGESAN, CMO e CRPPA) têm suas reuniões abertas aos cidadãos sem direito a voto. Apenas o CMPU tem suas reuniões fechadas e, por isso, há obrigatoriedade de promover a Conferência Municipal de Política Urbana a cada dois anos, o que significa dizer, uma vez a cada mandato dos conselheiros.

O CMO tem uma revisão do seu Regimento em cada ciclo de atividades. Isto faz com que ele seja mais dinâmico e que seu funcionamento esteja de acordo com as necessidades de seus membros.

Existe uma imprecisão quanto às atribuições do CRPPA, definidas de forma vaga, como descrito abaixo. Este pode ser um dos 
motivos dos conflitos existentes neste conselho, como mostram os dados a seguir.

Segundo Philippi Jr. e Bruna (2004, p. 678) "é preciso poder contar com uma gestão integrada dos temas pertinentes ao setor, o que se materializa por meio de políticas públicas que geram planos, programas e projetos". Esta integração deve acontecer entre os conselhos, uma vez que estes estão relacionados com as políticas públicas. No regimento de cada conselho são definidas as características de seus membros. Alguns deles especificam entre os representantes do poder público, quais são as instituições de origem, e, entre os representantes da sociedade civil, alguns membros de outros conselhos. No esquema abaixo [figura 50] estão indicadas as relações entre estes eles e as instituições que os gerem. Em cinza, estão os representantes do poder público de cada uma das quatro instituições em outros conselhos; uma ligação mais tênue, uma vez que o funcionário não necessariamente participa do conselho de sua instituição de origem. Em preto, estão os conselheiros da sociedade civil que participam de outro conselho. Apesar de apenas a ligação entre CRPPA e COMUGESAN ser biunívoca, ou seja, o CRPPA tem uma cadeira para o conselheiro do COMUGESAN e vice-versa, as demais relações acabam por ser biunívocas também, uma vez que o conselheiro passa a participar dos dois conselhos de qualquer forma. Não existe representação de conselheiros da sociedade civil entre CRPPA e CMPU, nem entre CMO e COMUGESAN. 


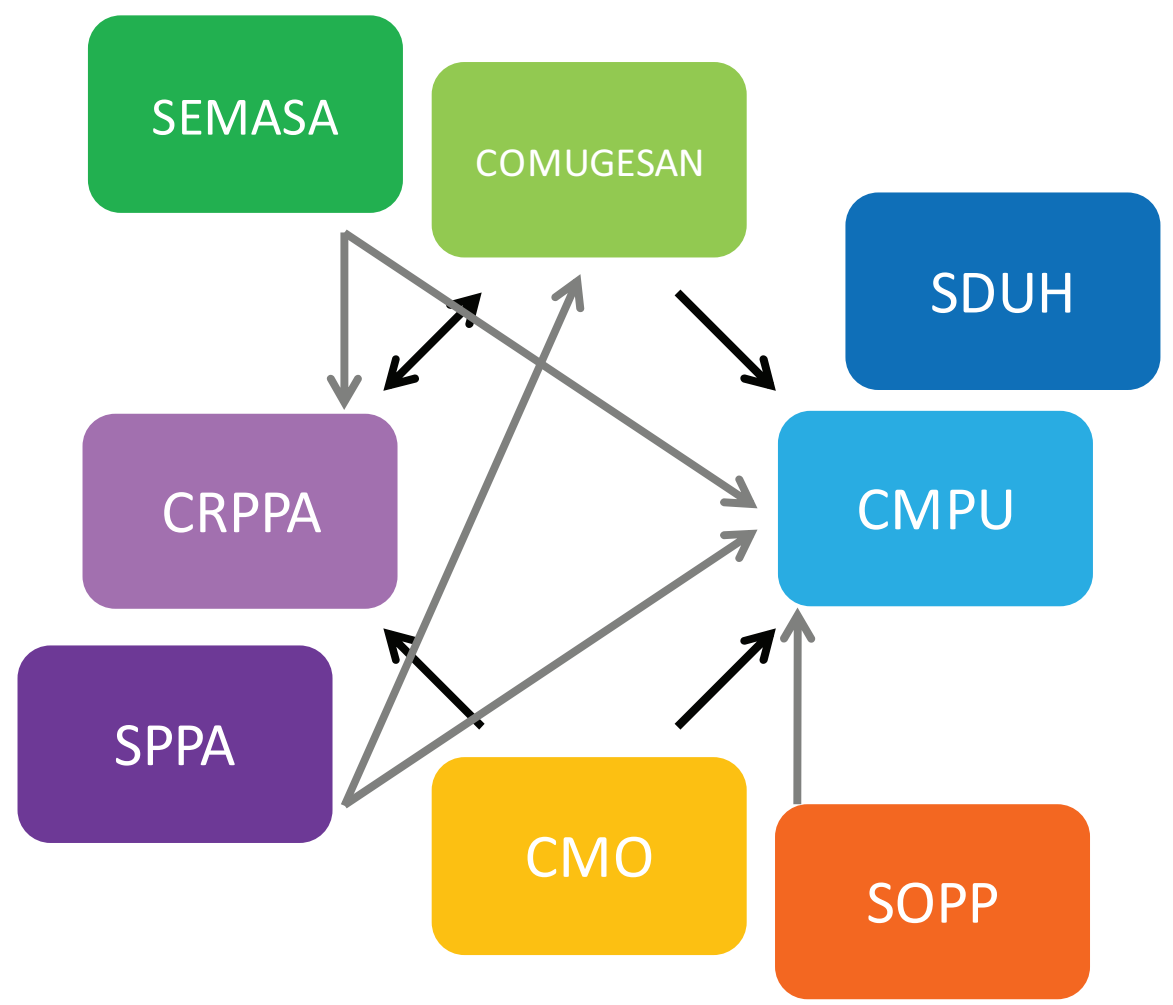

Figura 50: relação de representação entre os conselhos estudados Fonte: Vendramini, 2010

\subsubsection{CMPU}

Embora na lei Orgânica de Santo André (SANTO ANDRÉ, 1990) já tivesse sido criado o Conselho Municipal de Desenvolvimento Urbano em seu artigo 146, o CMPU, tal como funciona atualmente foi criado e regulamentado no Plano Diretor municipal, Lei 8.696/2004 (SANTO ANDRÉ, 2005). O CMPU é composto por 38 conselheiros de forma paritária, sendo 19 indicados pelo executivo municipal e 19 representantes da sociedade civil organizada, eleitos para este fim.

Os representantes do poder público, assim como seus suplentes devem pertencer a áreas relacionadas à política urbana do Município, nomeadamente: Secretaria de Desenvolvimento Urbano, Secretaria de Orçamento e Planejamento Participativo, Secretaria de Inclusão Social e Habitação, Secretaria de Desenvolvimento e Ação Regional, 
Secretaria de Finanças, Secretaria de Serviços Municipais, SEMASA, Subprefeitura de Paranapiacaba e Parque Andreense (SANTO ANDRÉ, 2005).

Os representantes da sociedade civil devem ser: cinco representantes dos empresários, sendo, pelo menos, um do setor imobiliário, um da construção civil e três dos demais setores econômicos; cinco representantes dos movimentos sociais, sendo necessariamente dois dos movimentos de habitação e um de sindicato de trabalhadores; quatro representantes de organizações não-governamentais, entidades técnicas ou profissionais e instituições de ensino ou pesquisa, sendo um de entidade ambiental, um de categoria profissional relacionada a desenvolvimento urbano, um de entidade ligada à preservação do patrimônio e um de instituição de ensino ou pesquisa; cinco representantes dos conselhos municipais afins - Habitação, Saneamento Ambiental, Transporte, Orçamento e Desenvolvimento Econômico.

O Conselho tem como competências: acompanhar a implementação do Plano Diretor, analisando e deliberando sobre questões relativas à sua aplicação; deliberar e emitir pareceres sobre proposta de alteração da Lei do Plano Diretor; acompanhar a execução de planos e projetos de interesse do desenvolvimento urbano, inclusive os planos setoriais; deliberar sobre projetos de lei de interesse da política urbana, antes de seu encaminhamento à Câmara Municipal; gerir os recursos oriundos do Fundo Municipal de Desenvolvimento Urbano; monitorar a concessão de Outorga Onerosa do Direito de Construir e a aplicação da transferência do direito de construir; aprovar e acompanhar a implementação das Operações Urbanas Consorciadas; acompanhar a implementação dos demais instrumentos urbanísticos; zelar pela integração das políticas setoriais; deliberar sobre as omissões e casos não perfeitamente definidos pela legislação urbanística municipal; convocar, organizar e coordenar as conferências e assembléias territoriais; convocar audiências públicas; elaborar e aprovar o regimento interno (SANTO ANDRÉ, 2005). 
O CMPU é regulamentado pelo Decreto 15.176, de 23 de fevereiro de 2005 e pelo Decreto 15.236, de 28 de junho de 2005, que aprova seu regimento interno(SANTO ANDRÉ, 2004a).

\subsubsection{COMUGESAN}

A Lei Orgânica Municipal de Santo André determinou, em 1990 (SANTO ANDRÉ, 1990), que deveria ser criado, pelo poder público o Conselho Municipal de Meio Ambiente, mas apenas em 1998 a lei 7733/98 (SANTO ANDRÉ, 1998) que estabeleceu a política municipal de Gestão e Saneamento Ambiental, instituiu o COMUGESAN.

O COMUGESAN é um conselho deliberativo e paritário composto por trinta membros sendo 15 representantes do poder público, indicados pelo prefeito, e 15 da sociedade civil organizada, eleitos para compor o conselho. Os representantes do poder público devem ser selecionados seguindo as seguintes normas: O Diretor Superintendente do SEMASA, que será seu presidente; O Diretor do Departamento de Gestão Ambiental do SEMASA ou seu representante; $O$ Subprefeito de Paranapiacaba e Parque Andreense ou seu representante e 12 representantes do Poder Executivo Municipal, escolhidos pelo Prefeito (SEMASA, 2004).

Os representantes da sociedade civil devem ser eleitos seguindo a seguinte regra: 3 representantes de organizações da sociedade civil; 3 representantes de associações ligadas aos setores do comércio, indústria ou serviços; 2 representantes de sindicato de trabalhadores; 1 representante de Instituição de Ensino ou Pesquisa; 2 representantes de entidades ligadas a classes de profissionais liberais; 2 representantes de associações e organizações não governamentais ambientalistas, com um ano de existência legal e experiência comprovada em ações de defesa do 
saneamento ambiental, do meio ambiente ou qualidade de vida; 1 representante da sociedade civil pertencente ao Conselho Municipal de Representantes da Subprefeitura de Paranapiacaba e Parque Andreense; 1 representante dos moradores de APRM - Parque Miami, Jardim Riviera e Recreio da Borda do Campo. Todas a instituições representadas devem possuir sede ou subsede em Santo André ou atuação comprovada em seu território (SEMASA, 2004).

Aos membros do COMUGESAN compete: participar da Plenária do COMUGESAN; discutir e votar todas as matérias para apreciação do COMUGESAN; apresentar propostas e sugerir matérias para apreciação do COMUGESAN; pedir vista de documentos referentes apenas de interesse do Conselho; solicitar ao Presidente a convocação de reuniões extraordinárias, justificando seu pedido formalmente; propor inclusão de matérias na ordem do dia, inclusive para reuniões subseqüentes, bem como prioridade de assuntos dela constantes; requerer votação nominal, secreta ou por aclamação; propor o convite, quando necessário, de pessoas ou representantes de entidades, públicas ou privadas, para participarem de reuniões específicas, para trazer subsídios às deliberações do COMUGESAN, com direito a voz, obedecidas as condições previstas neste regimento; propor a solicitação de informações de outros órgãos ou entidades, necessárias ao bom cumprimento das atribuições do COMUGESAN; fazer constar em memória de reunião pontos de vista ou votos divergentes do órgão ou entidade que representa, quando julgar relevante; zelar pelo cumprimento e observância do regimento (SEMASA, 2004).

O atual regimento do COMUGESAN foi aprovado na lei 8.676 de 22 de setembro de 2004. 


\subsubsection{CMO}

O Conselho Municipal do Orçamento é previsto pela Lei Orgânica do Município e regido pelo regulamento aprovado em 2008 (SANTO ANDRÉ, 2008). Suas reuniões são públicas, e os participantes da plenária têm direito a voz, sem direito a voto. O conselho é composto por 38 membros, sendo 19 representantes do poder público indicados pelo prefeito e 19 membros da sociedade civil, cada um representando uma das regiões da cidade [mapa 7].

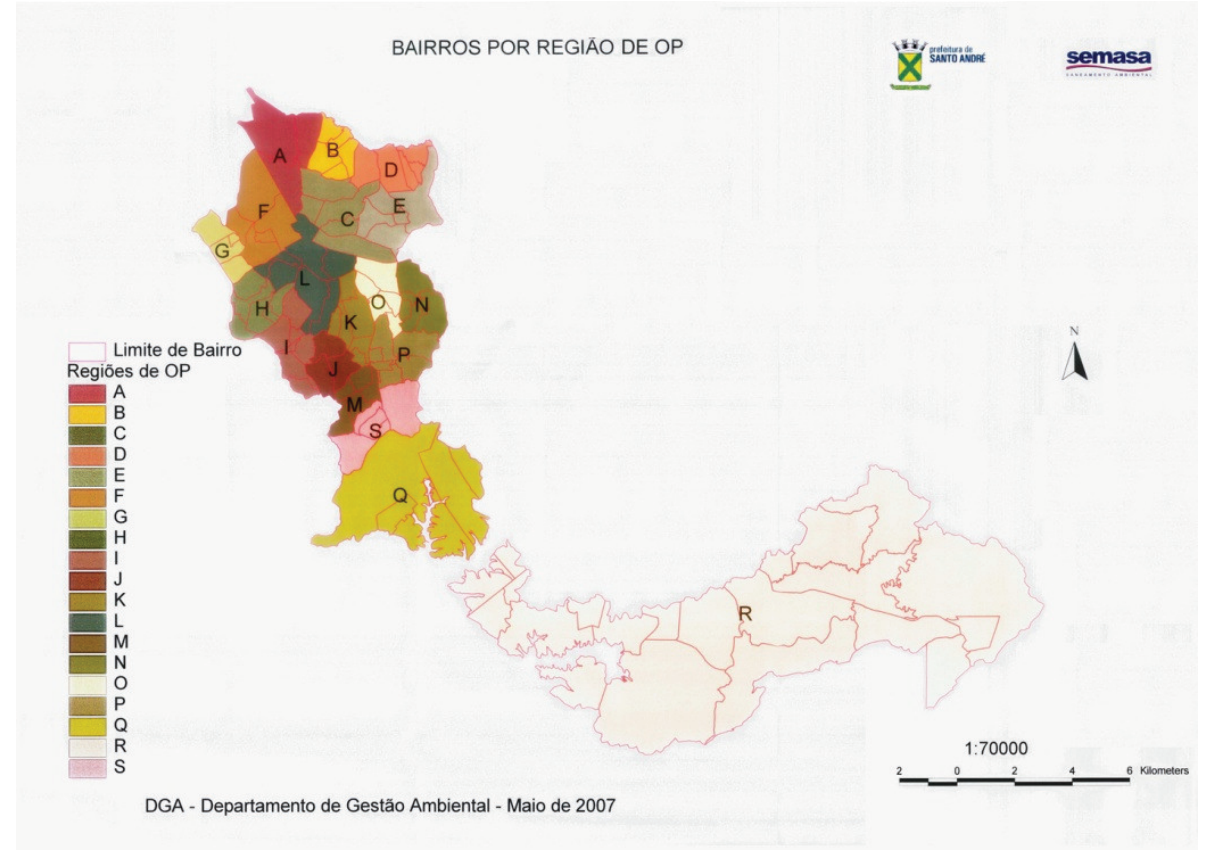

Mapa 7: regiões do OP de Santo André

Fonte: Prefeitura Municipal de Santo André - Secretaria de Desenvolvimento Urbano e Habitação, 2008.

As atribuições do conselho são: deliberar sobre o projeto de lei orçamentária a ser enviado pelo Poder Executivo à Câmara Municipal de Santo André; apreciar e emitir opiniões sobre a proposta de receita (alíquota dos impostos e taxas de serviços) do município; fiscalizar a execução orçamentária, opinando sobre eventuais cortes nos investimentos, incrementos ou quaisquer alterações no projeto inicial; deliberar sobre os assuntos encaminhados à apreciação do Conselho Municipal do Orçamento; 
aprovar a criação e dissolução de Grupos de Trabalho, respectivas competências, composição, procedimentos e prazo de duração; convocar as Reuniões Preparatórias, Plenárias Regionais de Prestação de Contas e Plenárias Regionais Deliberativas; eleger a Coordenação Paritária, escolhendo-a dentre seus membros; acompanhar e avaliar os relatórios fornecidos pela Secretaria Executiva do Conselho Municipal do Orçamento; alterar o dia de reuniões ordinárias, quando houver algum impedimento para que seja realizada no dia previsto; deliberar sobre a metodologia adequada para o Orçamento; e deliberar sobre possíveis modificações a serem introduzidas para os anos subseqüentes inclusive no regimento interno e outros procedimentos do Conselho Municipal do Orçamento (SANTO ANDRÉ, 2008).

Este conselho tem algumas particularidades em seu funcionamento. Uma delas é a Caravana das Prioridades, cujo objetivo é "garantir que todos(as) os Conselheiros e as Conselheiras tomem conhecimento da cidade e da realidade das várias prioridades e ações indicadas ao Conselho Municipal do Orçamento" (SANTO ANDRÉ, 2008). É programada uma visita à todas as regiões representadas no $\mathrm{CMO}$, de forma a que se faça uma parada por região e se apresente aos conselheiros as demandas de cada uma delas. Esta visita é realizada em um ou dois dias, dependendo na necessidade.

\subsubsection{CRPPA}

O Conselho de Representantes de Paranapiacaba e Parque Andreense foi criado no ano de 2001, junto com a Subprefeitura de Paranapiacaba e Parque Andreense. Sua criação foi decorrente de um processo de discussões com a comunidade, seguida de eleição direta nos 
bairros com participação de 837 moradores (CAETANO, 2006). Sua existência não está prevista na Lei Orgânica do município.

O CRPPA, segundo seu regimento, é composto por 20 membros, sendo 10 representantes do poder público e 10 da sociedade civil. Os conselheiros do governo são nomeados pelo prefeito municipal e representam os seguintes segmentos: saúde, educação, cultura, esporte e lazer, SEMASA, obras e serviços públicos e SPPA. Os conselheiros da sociedade civil devem ser eleitos com a seguinte proporção: 1 representante da Região 1 (Gleba 2, Gleba 3 e Jardim Clube de Campo); 1 representante da região 2 (Paranapiacaba e Campo grande); 1 representante da região 3 (Estância Rio Grande, Chácara Carreiras, Jardim Sílvia e Jardim Eugênio de Lima); 1 representante da região 4 (Parque América e Parque Rio Grande); 1 representante dos comerciantes da Subprefeitura; 1 representante de cada um dos seguintes conselhos: saúde, educação, CMO, COMUGESAN; 1 representante de entidade não governamental da região da subprefeitura (SPPA, 2001?).

No regimento não tem uma seção que expresse detalhadamente as atribuições do conselho, sendo expressas apenas no:

Artigo $1^{\circ}$ - $\mathrm{O}$ Conselho de Representantes tem eminentemente caráter público.

$\S 1^{\circ}$ - O Conselho de Representantes tem atribuições de fiscalização, consultivas e deliberativas.

$\S 2^{\circ}$ - O Conselho de Representantes deve agir para estimular o desenvolvimento regional e a ampliação da democracia na gestão da região de Paranapiacaba e Parque Andreense (SPPA, 2001?).

Outro problema do regimento é a falta de atualização. Sabese através de participação nas reuniões que, atualmente, o conselho é composto por 14 membros da sociedade civil e 14 do poder público, mas isto não está oficializado. 


\subsection{ANÁLISE DAS ENTREVISTAS COM OS CONSELHEIROS}

Das 20 questões aplicadas aos conselheiros municipais de Santo André, nove foram utilizadas nesta tese. Para esta análise, as questões foram separadas e salvas em arquivos de som do tipo "MP3" uma a uma, de forma que para cada entrevistado foram gerados 20 arquivos com cada uma das 20 questões.

Estes áudios foram ouvidos e analisados de acordo com a questão, conselho e representação e, a partir deles, foram geradas categorias de significados. Existem então respostas de conselheiros que têm mais de um significado, cada qual pertencente a uma categoria distinta, já que as questões foram abertas e as respostas consideradas por completo. Isto significa dizer que a soma das respostas totaliza bem mais que $100 \%$, sendo que as porcentagens espressas representam a proporção de conselheiros que, em suas respostas, apresentaram conteúdos pertencentes à categoria que está sendo apresentada ${ }^{42}$.

As entrevistas realizadas podem esclarecer algumas particularidades dos conselhos de Santo André. Os dois conselhos que gerem as políticas urbanas de seus setores, o CMPU e o COMUGESAN, deixam este caráter explícito nas análises. Este aspecto é mais forte ainda no CMPU. As Câmaras Técnicas destes conselhos possuem um funcionamento constante que é reiterado pelos entrevistados sempre que o assunto da questão permite. As deficiências na capacitação dos conselheiros são perceptíveis para os quatro colegiados estudados, mas estão mais evidentes nestes conselhos de caráter técnico, cujos membros sentem mais falta de

\footnotetext{
${ }^{42}$ Nas quantificações das respostas quatro situações geraram respostas não válidas: quando o entrevistado não respondeu a pergunta; quando o entrevistado respondeu algo que não tem relação com a pergunta; quando a resposta foi induzida pelo entrevistador; e quando o entrevistador pulou a pergunta.
} 
informações para deliberar. Outra particularidade é o interesse de seus participantes em um sistema de capacitação, melhor expressado pelos representantes da sociedade civil em oposição ao pensamento dos membros do governo que dizem que os conselheiros devem buscar as informações que precisam. Deve-se lembrar que, colher os dados necessários para uma boa atuação no conselho é mais simples para este últimos, pois têm acesso ao que precisam no seu trabalho diário na prefeitura.

O CMO e o CRPPA são dois conselhos de caráter diferente dos anteriores. São espaços para que a sociedade civil possa reivindicar o que julga necessário para sua qualidade de vida. As entrevistas explicitam os papeis dentro do conselho. O poder público é o provedor de informações, aspectos técnicos e limites das ações, enquanto que a sociedade civil traz as informações do "lócus" que só o cidadão possui e as demandas de seus representados. Este último é um aspecto que aparece em todos os conselhos, mas que é mais evidente nestes dois. O caráter deliberativo do CMO e do CRPPA aparece nas entrevistas, mas é muito mais explicitado pelos conselheiros do poder público do que pelos membros da sociedade civil organizada. O papel fiscalizador dos quatro conselhos estudados é muito pouco lembrado nas entrevistas de maneira geral. A exceção fica por conta do poder público do CRPPA, onde $67 \%$ dos entrevistados o mencionam.

Os membros destes conselhos gostariam de receber mais prestação de contas por parte do governo e mais informações que auxiliassem na sua atuação nas reuniões. Para os conselheiros do poder público, estas informações deveriam ser democratizadas através de capacitação, e, para os da sociedade civil, os participantes do conselho devem buscar os dados que precisam para atuar nas reuniões. Vale ressaltar que, de maneira geral, os conselheiros do CMO aprovam a capacitação que recebem, mas, tanto os membros do poder público, quanto os da sociedade civil, sentem falta de conhecer o valor do orçamento com que trabalham. 
O CRPPA é um conselho que enfrenta problemas já superados pelos demais colegiados estudados. Existe uma forte desorganização da sociedade civil para participar das reuniões, muitas faltas, muitos conflitos internos. Este foi o único dos quatro conselhos estudados onde metade das pessoas da sociedade civil afirmaram que os conselheiros não estão suficientemente informados para participar do conselho.

Os membros dos quatro conselhos mostraram que estes conselhos efetivamente agem como um canal de diálogo, tendo a democracia e a participação como pontos positivos. A ampliação da transparência da administração pública foi pouco citada pelos entrevistados e na maioria das vezes por conselheiros do governo. Isto também ocorre com a menção ao compartilhamento de poder.

O que mais chama atenção nas entrevistas é a clareza com que se expressa a tendência dos conselheiros do poder público de votar em bloco, de acordo com a posição oficial. Isto fica mais claro nas respostas dos membros do governo no conselho.

\subsubsection{Questão 01 - O Papel do Conselho na Prática}

A questão número um da entrevista é: "Você pode me explicar qual é o papel do conselho na prática?" O objetivo desta questão é levantar quais são de fato as atividades do conselho ${ }^{43}$.

43 A partir deste ponto, como forma de se preservar a autoria de análises realizadas com estes dados, serão indicadas as concordâncias e discordâncias entre estes resultados e os obtidos no relatório do Projeto Mega entregue para a FAPESP em outubro de 2009: Relatório de pesquisa, parte integrante do projeto MEGA - Avaliação Estratégica do Processo de Implementação das Políticas de Desenvolvimento e Meio Ambiente no Município de Santo André - SP 


\section{CMPU · poder público}

Dos 15 conselheiros do poder público no CMPU que deram respostas válidas para esta questão, nove (60\%) afirmam que o papel do conselho na prática é elaborar, aprimorar e aplicar as leis relacionadas com 0 planejamento urbano municipal e seis (40\%) remetem as funções do CMPU diretamente à gestão da política pública urbana. A deliberação sobre a outorga onerosa e o impacto de vizinhança foi citada por cinco (33\%) conselheiros. Três (20\%) conselheiros disseram que o papel do conselho seria discutir assuntos da cidade, e um (7\%) mais especificamente, afirmou que seria "montar cenários da cidade que queremos". Apenas dois (13\%) conselheiros lembraram que uma das funções do conselho é gerir o Fundo Municipal de Desenvolvimento Urbano. Outras duas respostas foram dadas por apenas um (7\%) conselheiro cada: o conselho seria um canal de diálogo com o poder público e um canal de recepção das demandas da sociedade civil, ambas relacionadas ao dialogo entre governo e sociedade.

"Discutir as questões relevantes da política urbana de Santo André [...] é um espaço importante para a sociedade civil trazer as demandas em relação à política urbana para discussão com o governo. É um canal que o governo tem para entender as demandas da sociedade civil e respondê-las."

CMPU $\cdot$ sociedade civil

Dentre os 13 conselheiros da sociedade civil, membros do CMPU, que deram respostas válidas para esta questão, a resposta mais freqüente foi dada por oito (62\%) conselheiros que afirmaram que o papel do conselho é a elaboração, aplicação e aprimoramento das leis. Sete (54\%) conselheiros atribuem ao conselho o papel de espaço para discutir os assuntos da cidade. Ainda nesta linha, quatro (31\%) conselheiros afirmam que o papel do conselho é montar cenários para construir objetivos comuns, uma cidade melhor. 


\begin{abstract}
"Aplicação do plano diretor e deliberação sobre os planos setoriais do plano diretor e das políticas de impacto urbanístico na cidade, ou seja, ele tem uma atribuição muito pesada. [...] Seria um super-conselho."

"O papel do conselho é estar discutindo, né? E buscando viabilizar algumas pendências para melhorar o município no geral $[\ldots] . "$
\end{abstract}

Várias outras respostas menos freqüentes foram dadas a esta questão. Quatro delas citadas por apenas dois (15\%) conselheiros: o conselho é um espaço de deliberação; o seu papel é gerir as políticas públicas urbanas; gestão do Fundo Municipal de Desenvolvimento Urbano; e o mesmo como canal de participação. Por fim, o papel de fiscalizar e monitorar a ação pública e de delegar sobre a outorga onerosa e o impacto de vizinhança foram mencionados por apenas um (8\%) conselheiro cada.

\title{
CMPU
}

De maneira geral, pode-se afirmar que o CMPU tem a função de gerir a Política Urbana do município e tem efetivamente cumprido essa função ${ }^{44}$. A deliberação sobre a outorga onerosa, que por algum tempo ocupou muito tempo das reuniões do CMPU foi reorganizada para que a Câmara técnica tenha autonomia para decidir, liberando tempo de conselho para as questões de fundo da política urbana.

"Por um longo período a gente estava percebendo que o
papel do CMPU era só referendar decisões que eram
tomadas em algumas câmaras internas, mas algumas
divisões do CMPU. As discussões de fundo mesmo
estavam ficando para trás, por exemplo, muitas das
reuniões deste ano foram usadas só para apreciação e
aprovação dos projetos de outorga onerosa. [...] Nós
estamos transferindo essa atribuição para a câmara
técnica do CMPU, para que isso não venha para discussão

${ }^{44}$ Análise corroborada pelo trabalho de Assis (2009). 
e a gente consiga espaço, de tempo inclusive, para fazer as discussões que são mais importantes."

Por outro lado, respostas que atribuam ao conselho, um papel de canal de comunicação entre governo e cidadão não são muito freqüentes. Isto pode ser atribuído a dois fatores. Em primeiro lugar, a matéria do CMPU é bastante técnica, o que dificulta o acesso do cidadão comum. Em segundo, o CMPU é um conselho fechado à participação de não membros, com exceção da Conferência Municipal de Política Urbana que acontece apenas uma vez a cada dois anos.

\section{COMUGESAN · poder público}

No COMUGESAN, oito conselheiros do poder público deram respostas válidas a esta questão. $O$ papel do conselho mais citado foi discutir a questão ambiental (cinco conselheiros - 63\%). A gestão da política ambiental foi mencionada por apenas dois (25\%) membros do conselho, assim como a função de aprovar o cancelamento de multas aplicadas pelo SEMASA pelo descumprimento da legislação.

"Desenvolver políticas públicas relacionadas com o meio ambiente de maneira global."

A maioria das respostas, seis delas, foi citada por apenas um (13\%) conselheiro, e são: a construção de cenários para um cidade melhor; o conselho como espaço de deliberação; a elaboração, a aplicação e o aprimoramento das leis e planos; canal de recepção das demandas da sociedade civil; participação, canal para receber informações.

"A minha participação no CONUGESAN é menos ativa que no [outro conselho]. O que eu tenho participado do COMUGESAN, a gente tem, no fundo, recebido informes de ações que a administração tem preparado ou feito na cidade. Não tem sido um fórum de decisões. Principalmente no sentido de informar a sociedade, 
principalmente os conselheiros da sociedade civil o que tem acontecido. E para muito dos representantes também, mostrar os trabalhos que desenvolvem nas suas associações, agremiações."

COMUGESAN $\cdot$ sociedade civil

Entre os nove conselheiros da sociedade civil que deram respostas válidas, a mais freqüente foi que o conselho funciona como local de discussão da questão ambiental. Esta resposta foi dada por cinco (56\%) conselheiros.

"O COMUGESAN funciona como órgão fiscalizador e gestor das questões ambientais da cidade, né? Do que está acontecendo que envolve a questão ambiental da cidade de uma maneira geral."

As demais respostas foram citadas por apenas dois (22\%) ou um $(11 \%)$ conselheiro. Por dois membros do conselho foram lembrados: 0 conselho como espaço de deliberação; o papel de fiscalizar e monitorar a ação pública; local onde se recebe informações sobre o andamento da questão ambiental no município; e deliberações sobre o perdão de multas e tarifas. Somente um conselheiro falou que o conselho tem o papel de: elaborar, aplicar e aprimorar as leis e planos; gerir a política ambiental municipal; e de ser um canal de participação.

\section{COMUGESAN}

Existe um consenso entre os conselheiros representantes do governo e os representantes da sociedade civil organizada no COMUGESAN sobre seu principal papel: discutir a questão ambiental ${ }^{45}$. Além de esta resposta ter sido dada pela maioria dos membros das duas representações (63\% do poder público e $56 \%$ da sociedade civil), as demais respostas foram

45 Análise corroborada pelo trabalho de Nunes (2009). 
pouco freqüentes e muito esparsas. Os conselheiros não falam em deliberar, apenas em discutir. Some isto à resposta receber informes dada por 2 conselheiros da sociedade civil e um do poder público.

CMO - poder público

No CMO, 13 conselheiros do poder público deram respostas válidas a esta primeira questão. Destes, oito (62\%) disseram que o papel do conselho é discutir o orçamento municipal e cinco (38\%) apontaram o CMO como espaço de deliberação.

\section{"[...] é uma forma de você conseguir discutir com pelo menos algumas lideranças da cidade como funciona a questão do orçamento público municipal." \\ "O principal papel do conselho é estar deliberando sobre as demandas que vieram das regiões."}

Outras respostas freqüentes entre os entrevistados tratam o CMO como um canal de recepção por parte da prefeitura das demandas da população; canal de diálogo como o poder público e canal de participação e cidadania, cada uma delas sendo citada por três (23\%) conselheiros.

Apenas dois (15\%) membros do conselho falaram do papel de fiscalização e monitoramento do conselho e um (8\%) remeteu ao conhecimento local que só a população pode fornecer e afirmou que o conselho seria o canal por onde este conhecimento chegaria ao poder público.

"[...] e depois acompanhar a execução, cobrar se está sendo feito ou se não está, porque está atrasado o cronograma." 
$\mathrm{CMO} \cdot$ sociedade civil

Entre os 14 conselheiros da sociedade civil que deram respostas válidas, seis (43\%) afirmam que o principal papel do CMO é discutir o orçamento e cinco (36\%) identificam o conselho como canal de recepção das demandas pela sociedade civil. Duas respostas obtiveram quatro (29\%) menções cada. Em uma, o CMO é um canal de diálogo com o poder público, e na outra, local de participação, cidadania ou democracia. Apenas dois (14\%) entrevistados afirmam que o Conselho é um canal onde se busca conhecimento na população.

"O intuito e a prática é você escolher a prioridade para a população. A população participa então tem que escolher a prioridade e levar para a administração as prioridades. Nem sempre, a administração está lá em cima no prédio, ela não sabe qual é a prioridade de cada bairro. Santo André é grande. [...]"

$\mathrm{CMO}$

No CMO, as respostas estavam bastante concentradas em algumas categorias ligadas ao diálogo e à democracia, tanto entre os conselheiros do poder público, quanto entre os da sociedade civil, o que parece bastante positivo. O que chama a atenção é o fato de que cinco (38\%) conselheiros do poder público afirmaram que o CMO é um espaço de deliberação, e nenhum membro da sociedade civil citou esta resposta.

\section{CRPPA - poder público}

No Conselho de Representantes as sete respostas válidas dos membros do poder público estão bastante concentradas, duas delas foram lembradas quatro (57\%) vezes, e são: discutir com a sociedade civil e fiscalização e monitoramento. 
Três conselheiros falaram do aspecto deliberativo (43\%), embora o caráter consultivo prevaleça sobre o deliberativo, como mostram as respostas a seguir:

"Ele é fiscalizador, ele é consultivo e ele é deliberativo. Eu avaliando de uma forma geral ele trabalha mais com na questão consultiva."

"O Conselho ele é consultivo, ele é fiscalizador e ele é deliberativo em algumas questões, não em todas né."

"Organizador da questão orçamentária, do que eles vão investir na região, então também é como se fosse um OP, só que é bem definido, [...] ele tem o objetivo de definir também questões que vão ser realizadas naquele espaço. Isso são alguns encaminhamentos e agora tem decisões."

O conselho funciona também como canal de recepção de demandas da sociedade, e este aspecto foi citado por três (43\%) entrevistados. Dois (29\%) membros do conselho falaram da participação, cidadania e democracia advindas da existência do conselho. Apenas um (14\%) conselheiro apontou como papel do conselho transmitir informações do trabalho da prefeitura para a população.

CRPPA - sociedade civil

Entre os representantes da sociedade civil apenas cinco deram respostas válidas para esta questão, sendo que destes, quatro (80\%) apontaram que o principal papel do conselho é ser um canal de recepção de demandas da sociedade civil.

"Nós acompanha os problema do bairro e leva pro Conselho pra tentar solucionar junto ao poder público [...]."

"Pelo que eu fiquei sabendo ele serviria assim pra gente tá vendo o que tava precisando na rua da gente, nas outras ruas, no bairro e a gente vê direitinho e ir até lá 
fazer um relatório e ir até lá e representar pra eles lá no dia da reunião."

Um (20\%) conselheiro falou da abertura de diálogo com o poder público viabilizada pela existência do conselho, e outro citou a participação. Porém, houve um conselheiro que afirmou que o CRPPA serve para que as decisões previamente tomadas pelo governo sejam "homologadas".

\begin{abstract}
"É discutir né o que acontece, qual vai ser a interferência da prefeitura de fato no bairro. Só que isso acaba não acontecendo de fato né, em tese isso acontece [...] eles acabam utilizando o Conselho como pra homologar decisões já tomadas [...] ou seja, por capacidade ou seja pelo tamanho da intervenção a gente não consegue se alterar alguma decisão já tomada."
\end{abstract}

CRPPA

Entre os 12 entrevistados com respostas válidas no Conselho de Representantes, sete (58\%) falam do conselho como canal receptor de demandas da população, função bem parecida com a do CMO. Esta parece ser a principal função do conselho, embora o regimento seja muito vago e não permita este verificação. $O$ caráter deliberativo do conselho, que está explicito no regimento parece não prevalecer. Entre os conselheiros do poder público, três afirmaram que o conselho tem um caráter deliberativo, dois deles com ressalvas. Entre os membros da sociedade civil nenhum afirmou que o conselho tem o papel de tomar decisões.

\title{
Considerações
}

Após concluídas as análises por conselhos e por representação, as categorias de resposta foram agrupadas por semelhança e foram identificados oito contextos sobre o papel do conselho na prática. Destes oito, quatro foram agrupados dois a dois, como segue: 
Estas respostas estão quantificadas na tabela 2 e expressas nos gráficos 1 a 10 que seguem:

Tabela 2: papel do conselho " contextos

\begin{tabular}{|c|c|c|c|c|c|c|c|}
\hline & $\begin{array}{c}\text { respostas } \\
\text { válidas }\end{array}$ & $\begin{array}{c}\text { Papel do } \\
\text { Conselho } \\
\text { Contexto A }\end{array}$ & $\begin{array}{c}\text { Papel do } \\
\text { Conselho } \\
\text { Contexto B }\end{array}$ & $\begin{array}{c}\text { Papel do } \\
\text { Conselho } \\
\text { Contexto } A+B\end{array}$ & $\begin{array}{l}\text { Papel do } \\
\text { Conselho } \\
\text { Contexto C }\end{array}$ & $\begin{array}{c}\text { Papel do } \\
\text { Conselho } \\
\text { Contexto D }\end{array}$ & $\begin{array}{c}\text { Papel do } \\
\text { Conselho } \\
\text { Contexto C+D }\end{array}$ \\
\hline CMPU PP & 15 & 5 & 1 & 6 & 9 & 6 & 11 \\
\hline CMPU SC & 13 & 9 & 0 & 9 & 8 & 2 & 10 \\
\hline COMUGESAN PP & 8 & 6 & 1 & 6 & 1 & 2 & 3 \\
\hline COMUGESAN SC & 9 & 6 & 0 & 6 & 1 & 1 & 2 \\
\hline CMO PP & 13 & 11 & 3 & 12 & 0 & 0 & 0 \\
\hline CMO SC & 14 & 10 & 5 & 13 & 0 & 0 & 0 \\
\hline CRPPA PP & 6 & 5 & 3 & 7 & 0 & 0 & 0 \\
\hline \multirow[t]{2}{*}{ CRPPA SC } & 6 & 2 & 4 & 4 & 0 & 0 & 0 \\
\hline & & $\begin{array}{l}\text { respostas } \\
\text { válidas }\end{array}$ & $\begin{array}{l}\text { Papel do } \\
\text { Conselho } \\
\text { Contexto E }\end{array}$ & $\begin{array}{c}\text { Papel do } \\
\text { Conselho } \\
\text { Contexto F }\end{array}$ & $\begin{array}{c}\text { Papel do } \\
\text { Conselho } \\
\text { Contexto G }\end{array}$ & $\begin{array}{c}\text { Papel do } \\
\text { Conselho } \\
\text { Contexto H }\end{array}$ & \\
\hline & CMPU PP & 15 & 4 & 5 & 0 & 2 & \\
\hline & CMPU SC & 13 & 2 & 1 & 1 & 2 & \\
\hline & COMUGESAN PP & 8 & 1 & 2 & 0 & 0 & \\
\hline & COMUGESAN SC & 9 & 2 & 2 & 2 & 0 & \\
\hline & CMO PP & 13 & 5 & 0 & 2 & 0 & \\
\hline & CMO SC & 14 & 0 & 0 & 0 & 0 & \\
\hline & CRPPA PP & 6 & 3 & 0 & 4 & 0 & \\
\hline & CRPPA SC & 6 & 0 & & 0 & 0 & \\
\hline
\end{tabular}

Fonte: Vendramini, 2010.

Papel do Conselho - Contexto A: o papel do conselho é o de propiciar o diálogo entre poder público e sociedade civil. Isto também se expressa na forma de cidadania e democracia participativa; 


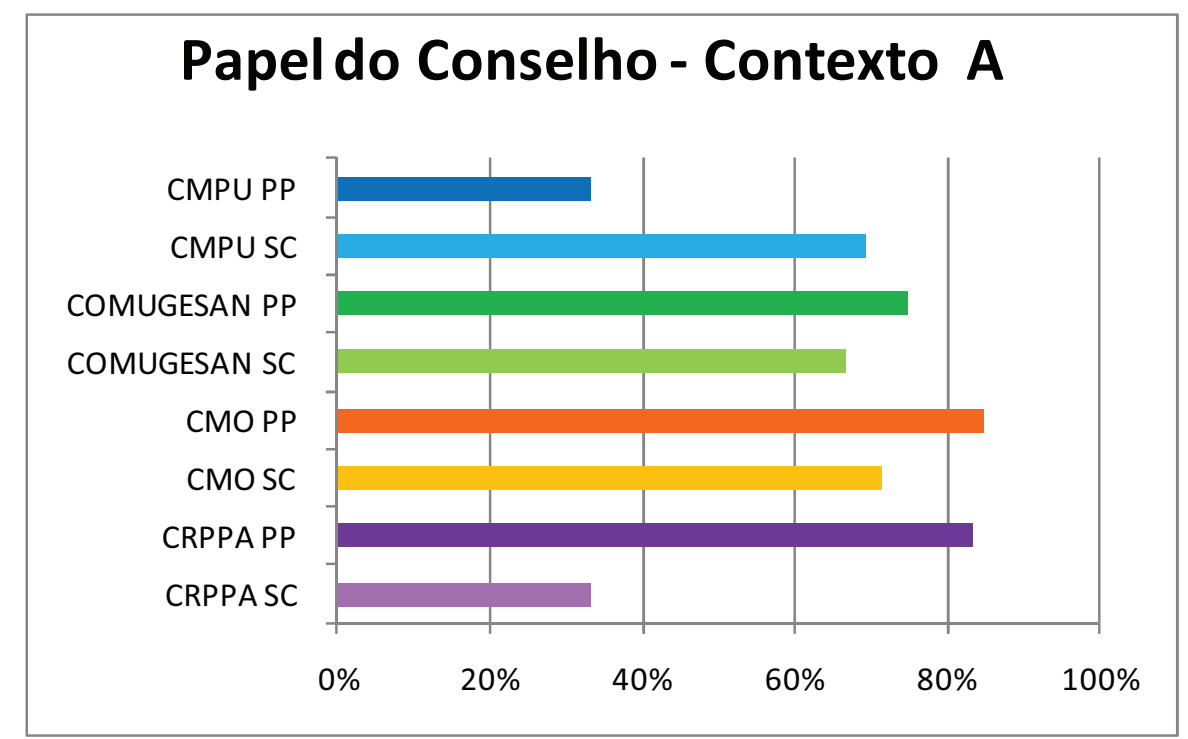

Gráfico 1: Papel do Conselho - contexto A

Fonte: Vendramini, 2010.

Papel do Conselho - Contexto B: também está relacionado com o diálogo, mas, mais especificamente, em receber as demandas advindas da população. Este contexto foi separado do anterior por ser um dos objetivo explícitos do CMO e um objetivo provável do CRPPA, que, como já foi mencionado anteriormente, não deixa claro em seu regimento quais são os objetivos do conselho;

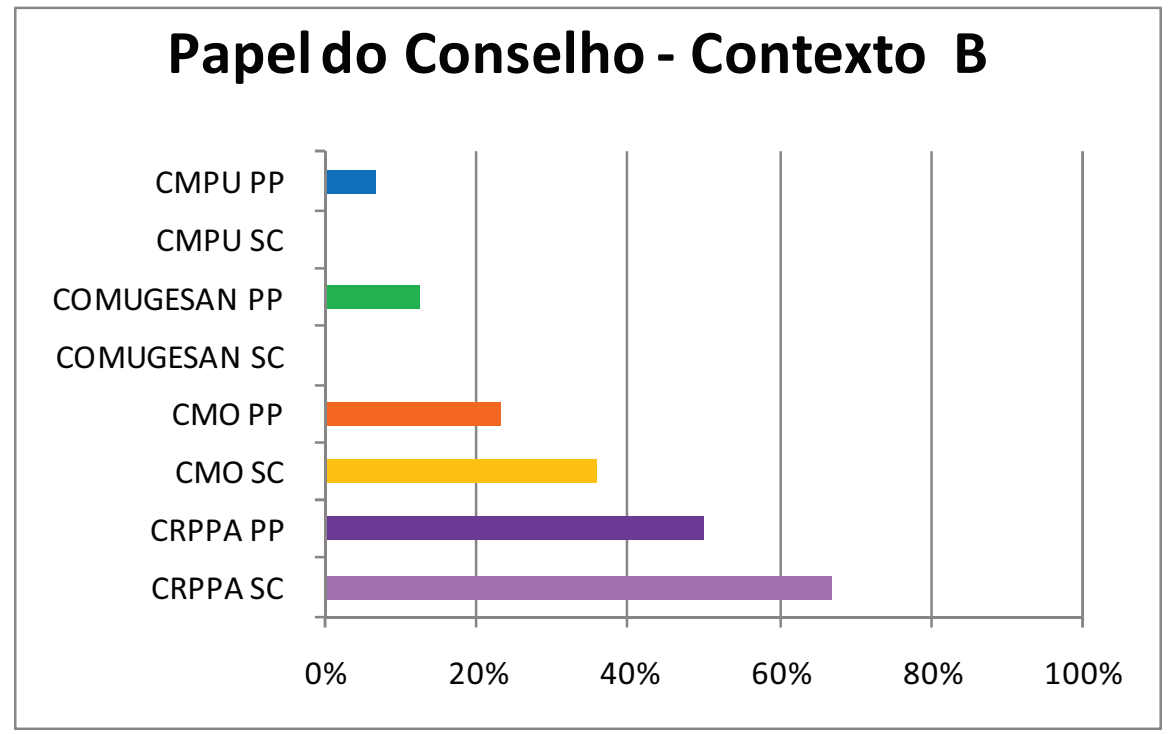

Gráfico 2: Papel do Conselho - contexto B

Fonte: Vendramini, 2010. 
Papel do Conselho - Contexto A+B: aqui são contabilizadas as respostas do contexto $\mathrm{A}$ e $\mathrm{B}$;

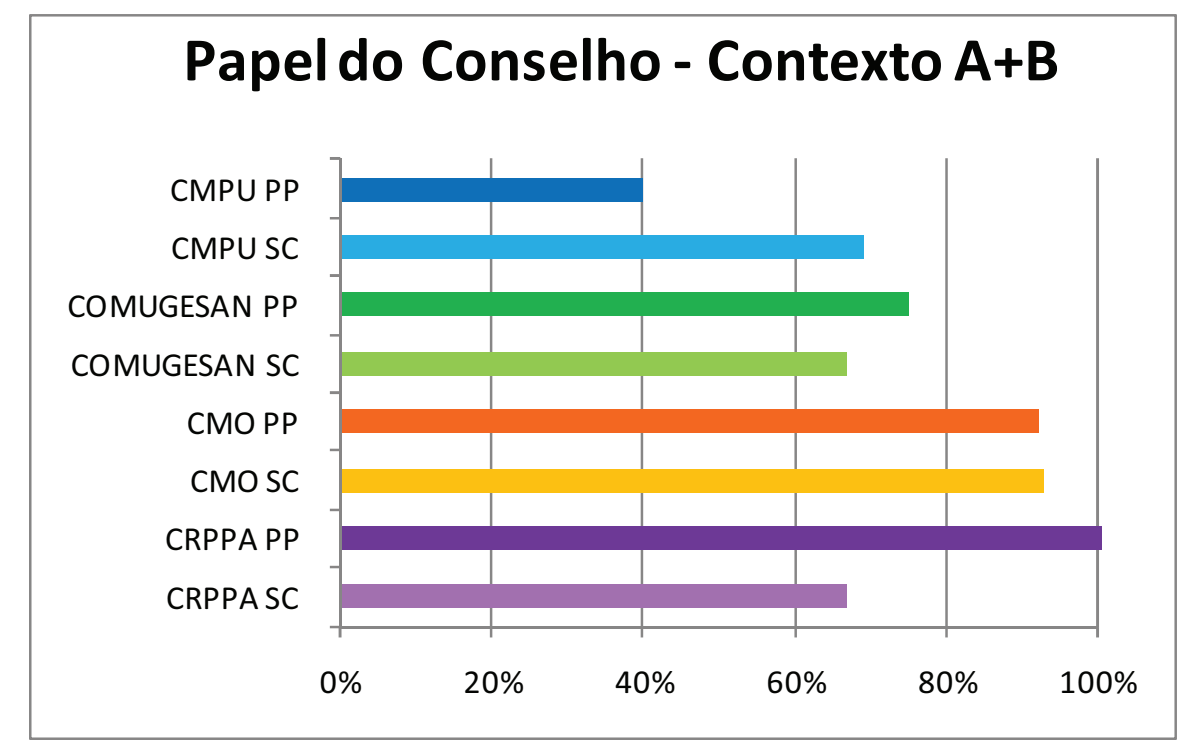

Gráfico 3: Papel do Conselho - contexto A+B

Fonte: Vendramini, 2010.

Papel do Conselho - Contexto C: neste contexto agrupam-se as respostas que falam de elaboração, aprimoramento ou aplicação de plano, programas, projetos e até de leis, mas que não mencionam literalmente o termo política pública;

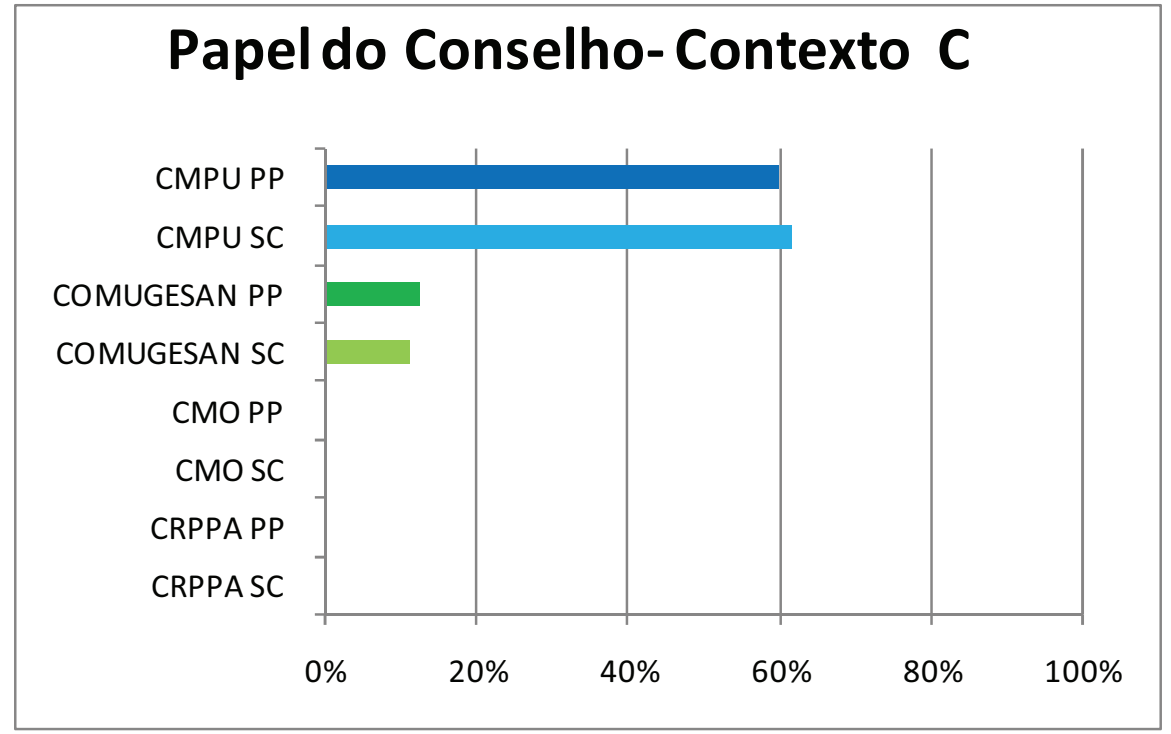

Gráfico 4: Papel do Conselho - contexto C Fonte: Vendramini, 2010. 
Papel do Conselho - Contexto D: neste contexto estão as respostas que citam a discussão ou a deliberação sobre políticas públicas;

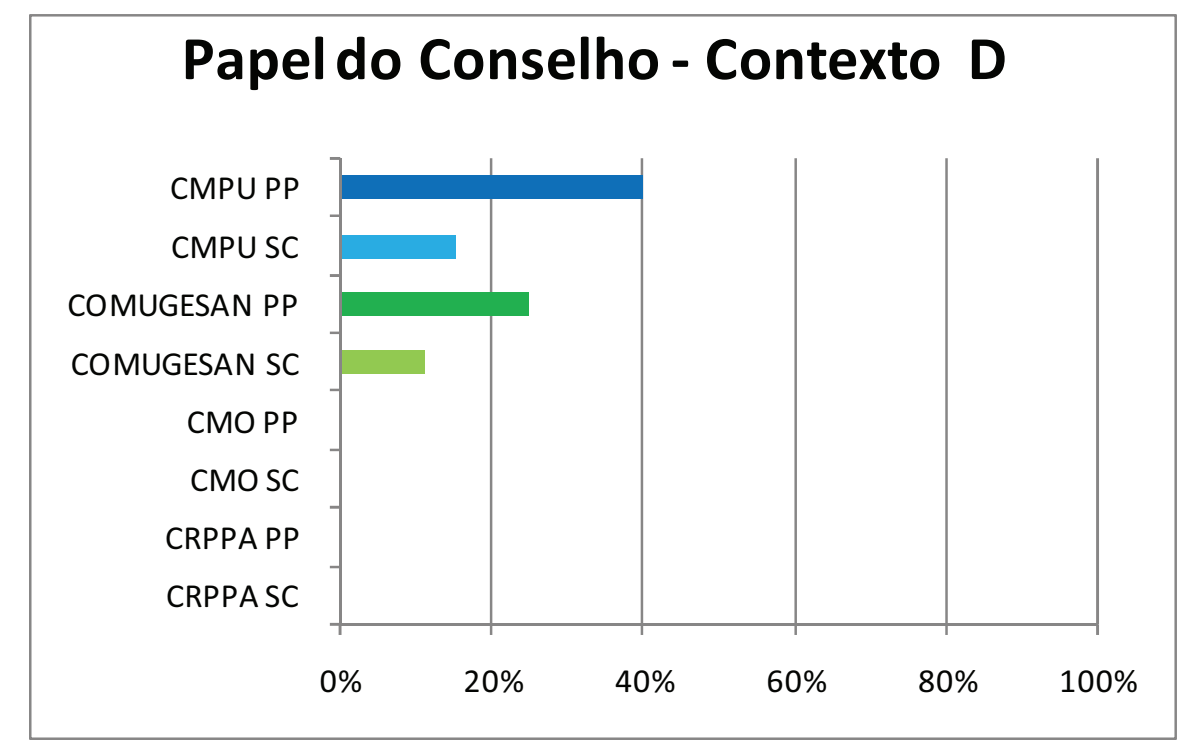

Gráfico 5: Papel do Conselho - contexto D Fonte: Vendramini, 2010.

Papel do Conselho - Contexto C+D: as respostas agrupadas aqui indicam consulta ou tomada de decisão sobre as políticas públicas ou qualquer um de seus desdobramentos;

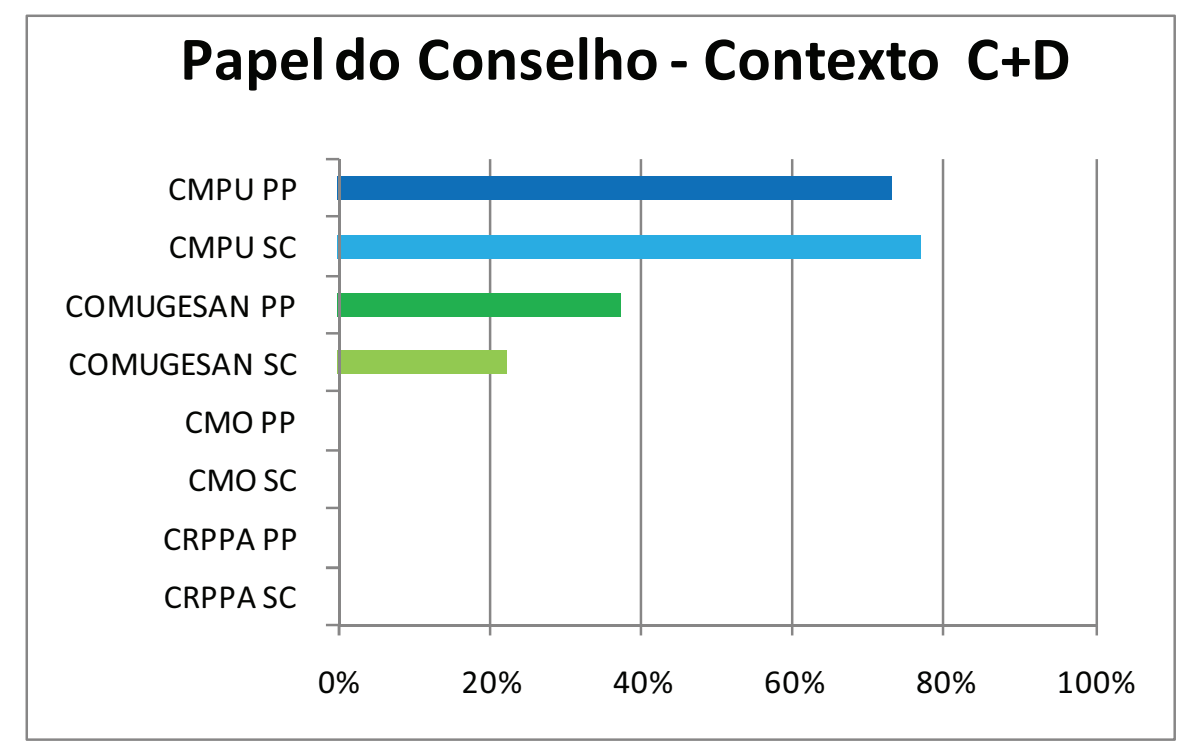

Gráfico 6: Papel do Conselho - contexto C+D Fonte: Vendramini, 2010. 
Papel do Conselho - Contexto E: neste contexto encontramse as respostas que expressam o poder de deliberação dos conselhos;

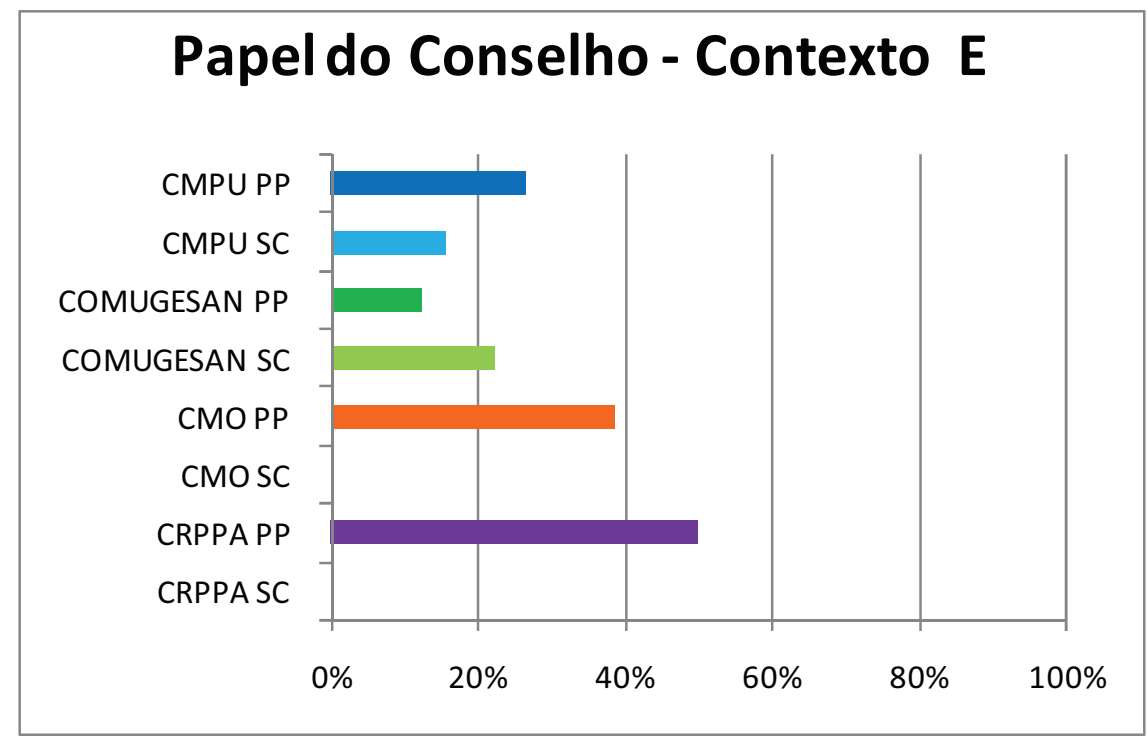

Gráfico 7: Papel do Conselho - contexto E Fonte: Vendramini, 2010.

Papel do Conselho - Contexto F: CMPU e o COMUGESAN são dois conselhos que possuem câmaras técnicas. Neste contexto seguem as respostas que citam os trabalhos dessas câmaras;

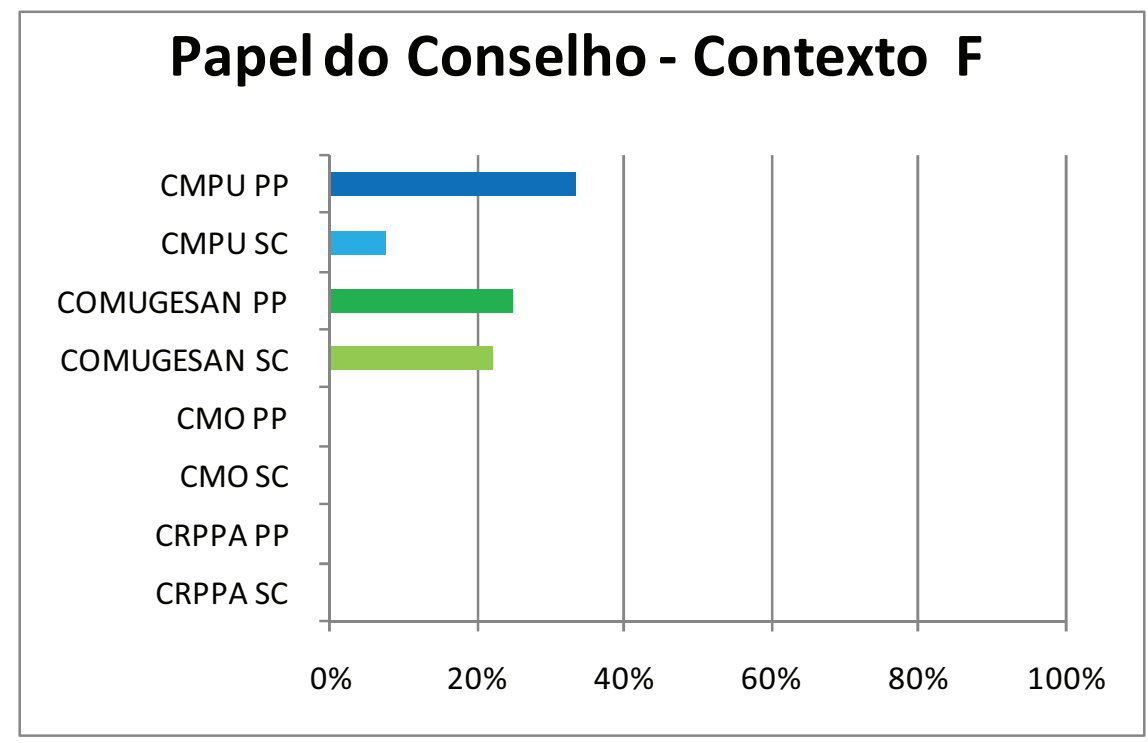

Gráfico 8: Papel do Conselho - contexto $\mathrm{F}$ Fonte: Vendramini, 2010. 
Papel do Conselho - Contexto G: monitoramento e fiscalização da ação pública;

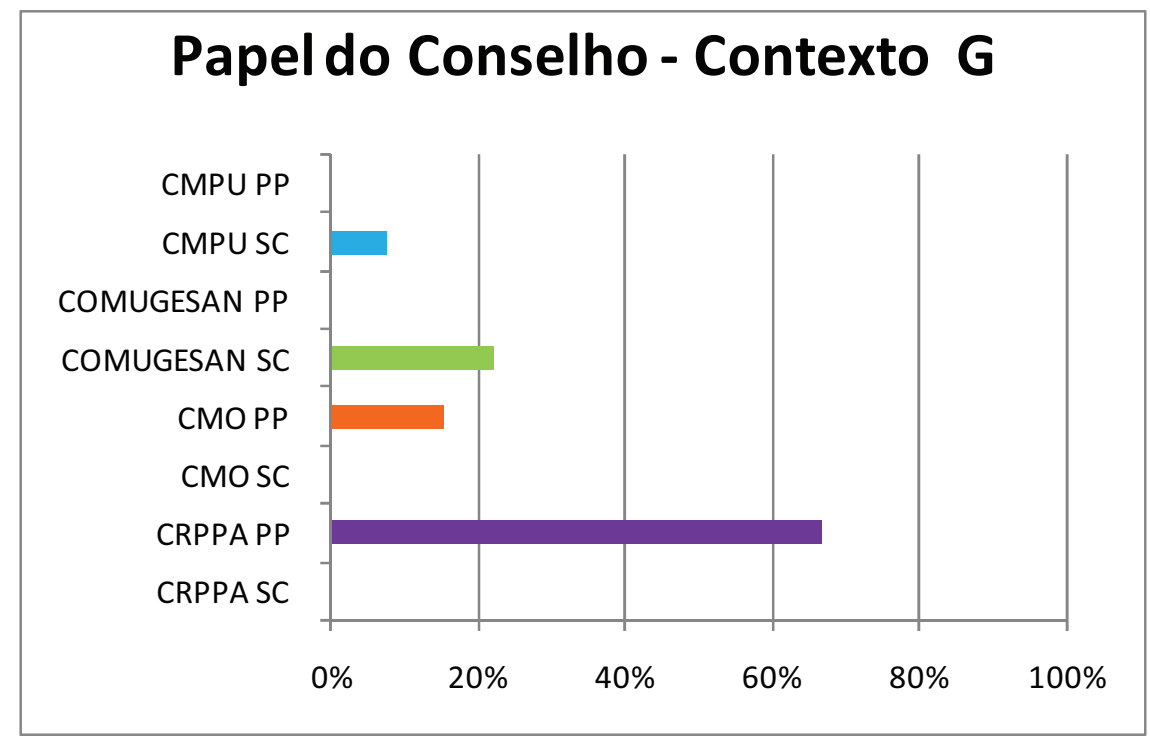

Gráfico 9: Papel do Conselho - contexto G Fonte: Vendramini, 2010.

Papel do Conselho - Contexto H: Gestão do fundo. Esta atribuição é exclusiva do CMPU.

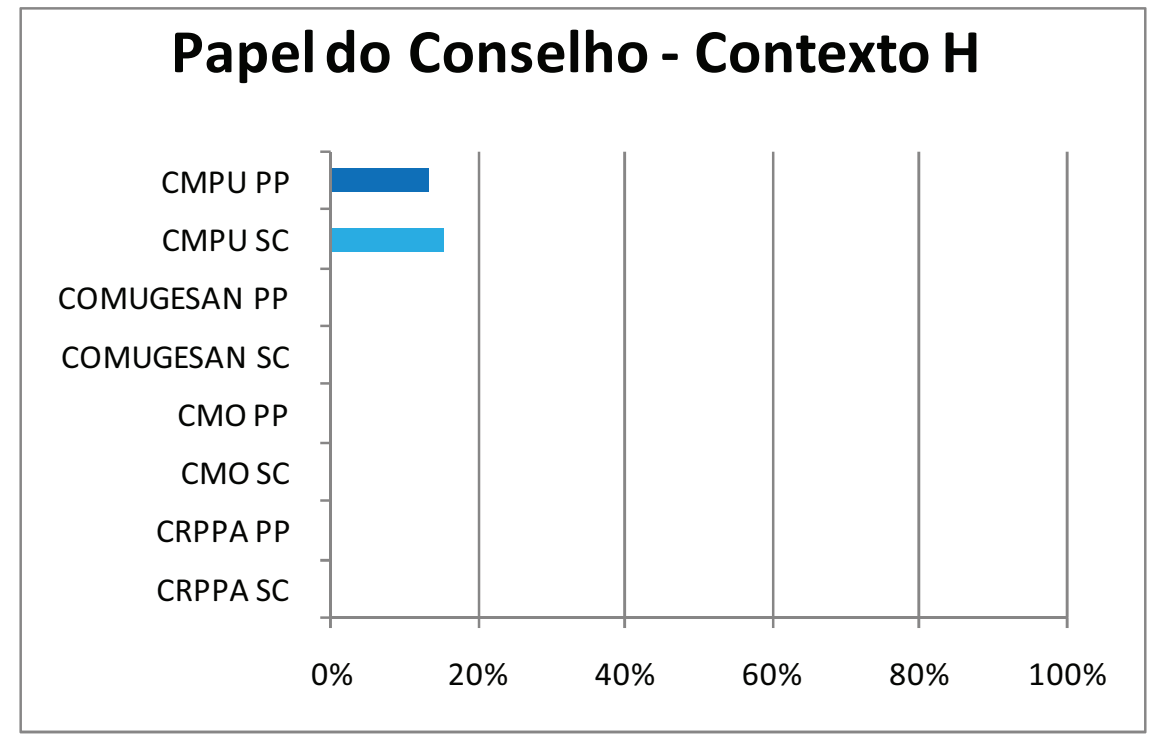

Gráfico 10: Papel do Conselho - contexto H Fonte: Vendramini, 2010.

Cabe ressaltar que no CRPPA um conselheiro da sociedade civil afirmou que o conselho é utilizado para legitimar decisões tomadas pelo 
poder público. Por ser uma única resposta de apenas um conselho, não foi gerado gráfico.

Ao analisar os gráficos, dos contextos explicativos do papel do conselho, pode-se notar que a grande maioria dos conselheiros dos quatro conselhos analisados entende que o papel dele na prática é estabelecer um canal de diálogo. No contexto $\mathrm{B}$, nota-se que o $\mathrm{CMO}$ e o CRPPA são realmente o canal para que o poder público receba as demandas da população. $\mathrm{O}$ que surpreende é que os valores do CRPPA são maiores que os do CMO, dado que este caráter reivindicativo do conselho, como já foi dito, não é explícito.

Os contextos $C$ e $D$, contabilizados no $C+D$ tratam do papel de gestor de políticas públicas que realmente é apenas do CMPU e do COMUGESAN. Pode-se notar que no CMPU este caráter é mais presente, reiterando o que foi encontrado nas entrevistas com os gestores de políticas públicas conforme apresentado. Na entrevista realizada com o SEMASA, o COMUGESAN é vagamente citado e lembrado. Menos até que o CMO, enquanto na entrevista realizada com a Secretaria de Desenvolvimento Urbano e Habitação, o CMPU é sempre lembrado inclusive como fruto do plano diretor e seu gestor.

O Contexto E aponta o conselho como espaço de deliberação, o que não é percebido pelos conselheiros representantes da sociedade civil do CMO e do CRPPA, o que faz refletir se essa deliberação realmente existe ou de que forma ela é realizada.

O Contexto $\mathrm{F}$ aponta para a menção às atividades nas câmaras técnicas. O resultado aponta para o efetivo funcionamento dessas câmaras uma vez que apenas uma parcela dos conselheiros fazem partes destes trabalhos. Apenas os conselhos CMPU e COMUGESAN têm câmaras técnicas e é por isso que, no Contexto $F$, apenas estes dois conselhos têm 
dados. Situação similar acontece com o Contexto $H$, visto que ele trata da gestão de um fundo que apenas é atividade do CMPU.

Por fim, no contexto G trata-se do papel de fiscalizador da ação pública. Ele é muito pouco lembrado, com exceção para o CRPPA, onde $67 \%$ membros do poder público o mencionaram. É interessante notar que o poder público, fiscalizado, lembrou desta atividade, mas a sociedade civil, fiscalizadora não a citou nenhuma vez. Isto reitera o caráter reivindicatório deste conselho.

\subsubsection{Questão 02 • As Atividades como Conselheiro}

A segunda questão da entrevista é: "E quais são suas atividades como conselheiro?" O objetivo desta questão é levantar quais são de fato as atividades do conselheiro.

CMPU · poder público

Entre os 15 conselheiros do poder público do CMPU que deram respostas válidas para esta questão, seis (40\%) mencionaram as decisões sobre a outorga onerosa. Realmente está foi uma atividade que demandou muito tempo, gerando uma revisão do seu funcionamento interno, como já foi explicado.

\section{"[...] você acaba deliberando sobre projetos de outorga onerosa na maioria das reuniões, coisa que a gente não tem capacidade técnica para deliberar."}

Quatro (27\%) membros do conselho enumeram como atividade: participar de câmaras técnicas e três (20\%) mencionaram: dar apoio técnico nas reuniões. Participar das reuniões, representar o poder público e desempenhar atividades administrativas foram atividades citadas 
por apenas dois (13\%) conselheiros. Realizar a ligação entre conselhos e colaborar com a elaboração de propostas de melhoria, foram atividades mencionadas por apenas um (7\%) participante do conselho.

\section{"Eu acompanho a proposta do governo sempre [...]." \\ "Basicamente a participação representando a secretaria de cultura $[\ldots] . "$}

Duas das respostas chamaram a atenção: apenas dois (13\%) conselheiros disseram que suas atividades incluíam discutir as políticas públicas, e um (7\%) afirmou que sua atividade é acompanhar as propostas do governo.

CMPU $\cdot$ sociedade civil

Dentre os conselheiros representantes da sociedade civil que deram respostas válidas para esta questão, as respostas mais freqüentes foram dadas por quatro (29\%) pessoas e foram: representar seu segmento da sociedade civil organizada; participar de câmara técnica; discutir políticas públicas e participar de reuniões.

Apenas um (7\%) membro do conselho citou que sua atividade seria monitorar a ação pública. Outras respostas dadas por apenas um conselheiro são: discutir e desempenhar atividades administrativas.

\footnotetext{
"Como conselheiro do CMPU eu sou representante da sociedade civil."

"Eu sou conselheiro representando uma entidade de classe (engenharia e arquitetura) [...] faço parte da câmara técnica [...] o acompanhamento dos assuntos relacionados à legislação de uso e ocupação do solo."
} 
CMPU

Enquanto apenas um (7\%) dos conselheiros do poder público do CMPU diz ter como atividade discutir políticas públicas, quatro (29\%) membros da sociedade civil têm clareza desta atividade. Outra diferença marcante entre os membros do conselho foi a não menção por parte dos participantes do poder público quanto à representação, resposta que foi lembrada por quatro (29\%) dos conselheiros da sociedade civil.

Vale notar que apenas um conselheiro da sociedade civil disse ser sua atividade monitor as ações públicas.

\section{COMUGESAN · poder público}

Entre os representantes do poder público no COMUGESAN houve apenas nove respostas válidas. Destes, três (33\%) mencionaram: participar das reuniões, participar de câmaras técnicas e discutir políticas públicas. Representar o governo, e votar foram respostas dadas por apenas dois $(22 \%)$ conselheiros.

As respostas menos lembradas por estes membros do COMUGESAN foram agregar conhecimento e deliberar sobre multas.

\section{"[...] Inserir algum conhecimento da forma do Estado no qual eu trabalho, para comunidades que estão participantes."}

\section{COMUGESAN $\cdot$ sociedade civil}

Os representantes da sociedade civil no COMUGESAN também produziram apenas nove respostas válidas. Destes, cinco (56\%) dizem que uma de suas atividades no conselho é discutir, opinar. Participar das reuniões do conselho e representar a sociedade civil foram respostas que foram mencionadas três (33\%) vezes. Discutir políticas públicas e votar foram atividades citadas por dois (22\%) conselheiros. Apenas uma (11\%) 
pessoa disse ser sua atividade participar das câmaras técnicas e outra lembrou a fiscalização da ação pública.

"Eu faço parte de uma Instituição Não Governamental e, dentro do papel do COMUGESAN procuro auxiliar no debate."

"Eu praticamente participo só das reuniões, não participo de nenhum grupo de trabalho. [...] e das decisões sobre os projetos, das apresentações."

\section{COMUGESAN}

No COMUGESAN, discutir políticas públicas está mais presente nas respostas dos conselheiros ${ }^{46}$ : três (33\%) do poder público e dois (22\%) da sociedade civil. Além disso, a discussão nas reuniões, sem menção a políticas, aparece nas respostas de dois (22\%) membros do poder público e 5 (56\%) da sociedade civil. Portanto, o diálogo parece estar muito presente nas reuniões do COMUGESAN.

A representação também foi mencionada de forma semelhante entre poder público (dois conselheiros - 22\%) e sociedade civil (três conselheiros - 33\%).

CMO - poder público

Os representantes do poder público do CMO deram 13 respostas válidas para esta questão. Parece ser claro para os representantes do poder público no conselho (seis membros - $46 \%$ ) que uma de suas atividades é dar apoio técnico às decisões que serão tomadas ${ }^{47}$. Quatro (31\%) conselheiros dizem que têm como atividade agregar conhecimento e quatro afirmam que discutem as questões do conselho. A participação nas

${ }^{46}$ Na análise de Nunes (2009), a principal atividade do conselho é participar das reuniões e votação.

47 Assis e Vendramini (2009) não quantificam sua análise, mas apresentam resultados semelhantes. 
reuniões apareceu em três (23\%) respostas e representar o governo foi mencionado por dois (15\%) conselheiros. Resolver conflitos, votar e fiscalizar a ação pública foram respostas dadas por apenas um (8\%) conselheiro.

\section{"[...] Meu papel é representar a administração pública enquanto secretaria de finanças, né, que tem papel dentro do conselho, e, quando somos solicitados, inclusive pela comunidade, é dar esclarecimentos. Inclusive na linha de informação e de formação [...]."}

$\mathrm{CMO} \cdot$ sociedade civil

$\mathrm{Na}$ sociedade civil participante do CMO obteve-se 13 respostas válidas. A mais expressiva foi, sem dúvida, o papel de representante da comunidade citado por nove (69\%) conselheiros. Outra atividade bastante lembrada (5 conselheiros $-38 \%$ ), e que tem bastante a ver com a de ser representante, está o papel de buscar e levar informações entre o conselho e os representados. Discutir e fiscalizar a ação pública foram atividades citadas por dois (15\%) conselheiros cada. Apenas um (8\%) membro do conselho afirmou que votar faz parte de suas atividades.

\section{"[...] O papel central é cobrar, fiscalizar, saber o que está acontecendo, se vai acontecer, se não vai $[\ldots . . . "$}

CMO

As respostas encontradas no CMO reiteram o papel do conselho. Os membros da sociedade civil têm a principal função de representar as demandas da população do município, enquanto os conselheiros do poder público devem dar o suporte técnico para que as decisões sejam tomadas. 
CRPPA · poder público

No CRPPA sete respostas válidas foram obtidas para esta questão. Para três (43\%) conselheiros uma das atividades é participar das reuniões. Apenas dois (29\%) membros do conselho citaram a função de dar apoio técnico nas reuniões do colegiado. Representar, exercer atividades administrativas e discutir foram atividades citadas por apenas um (14\%) representante do poder público no CRPPA.

\begin{abstract}
"Eu vou na reunião, contribuir no que é da minha área."
"Vou para as reuniões de Conselho representando o governo [...] você não tem muito como fazer a discussão né, avaliar como a situação de governo né e você representa o pensamento do governo, de uma forma geral."
\end{abstract}

CRPPA $\cdot$ sociedade civil

Na sociedade civil do CRPPA cinco (83\%) das seis repostas válidas mencionam a representação como atividade no conselho. Participar das reuniões, buscar ou levar informações e conseguir algum benefício foram atividades citadas por apenas um (17\%) conselheiro.

"Informar a população. Tentar articular a comunidade pra contrapor ou não alguma ação da prefeitura."

CRPPA

No CRPPA, fornecer apoio técnico foi uma atividade citada por apenas $29 \%$ dos conselheiros do poder público. Por outro lado, representar foi uma resposta dada pela maioria (83\%) dos conselheiros da sociedade civil. Isto reitera o caráter reivindicatório do conselho, semelhante ao do $\mathrm{CMO}^{48}$.

${ }^{48}$ Cezare (2009) não quantifica sua análise, mas apresenta resultados semelhantes.

VENDRAMINI, Paula R. Jorge - A participação em conselhos como instrumento de gestão municipal 


\section{Considerações}

De todas as respostas dadas à questão: "E quais são as suas atividades como conselheiro?" foram identificados nove contextos principais, que são apresentados na tabela 3 e nos gráficos 11 a 19.

Tabela 3: atividades no conselho * contextos

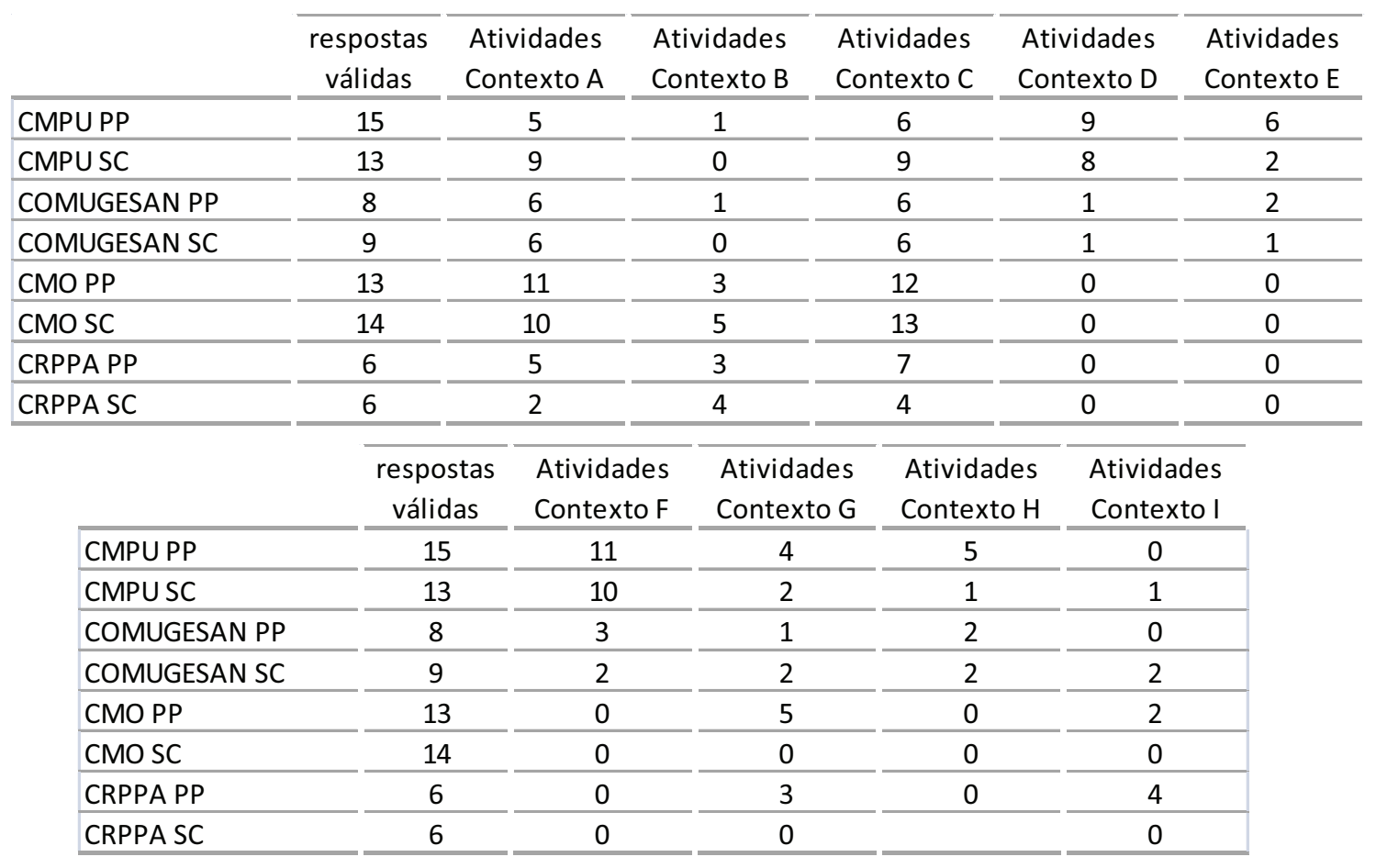

Fonte: Vendramini, 2010.

Atividades - Contexto A: agrupa as atividades burocráticas como participar das reuniões, exercer atividades administrativas no conselho ou votar; 


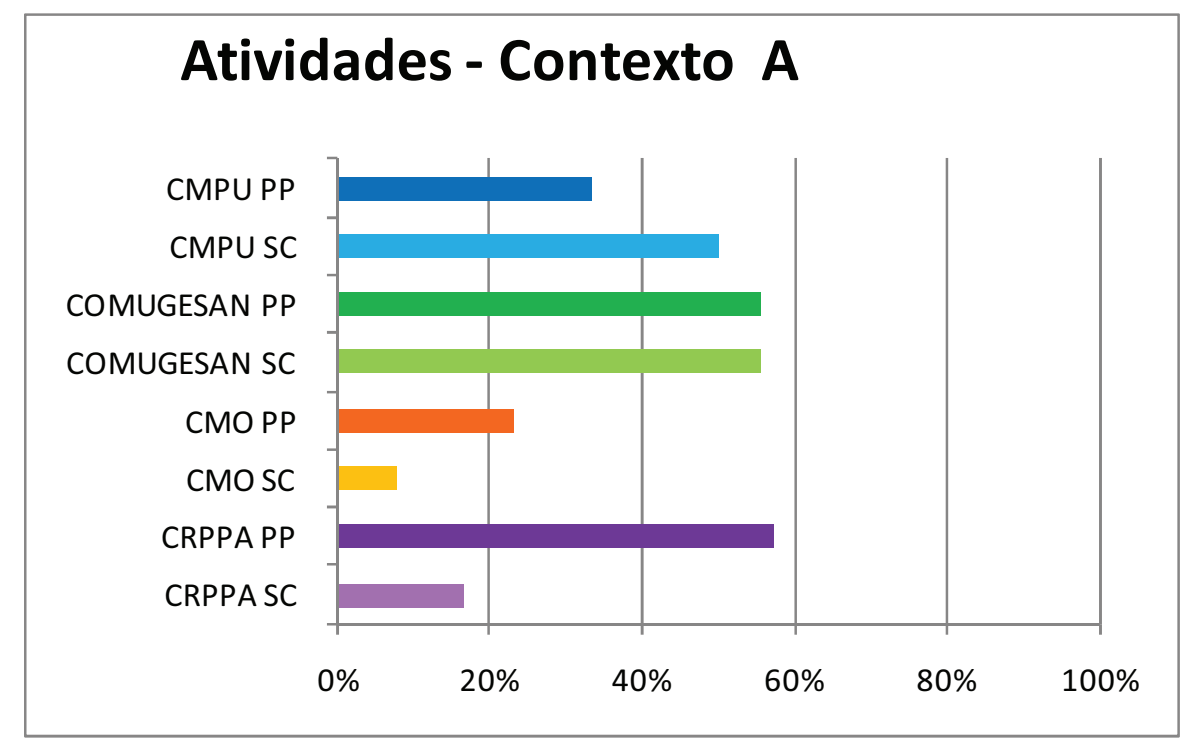

Gráfico 11: Atividades - Contexto A

Fonte: Vendramini, 2010.

Atividades - Contexto B: engloba as atividades que representam a dinâmica interna do conselho, como colaborar com a elaboração de propostas, discutir ou conseguir benefícios;

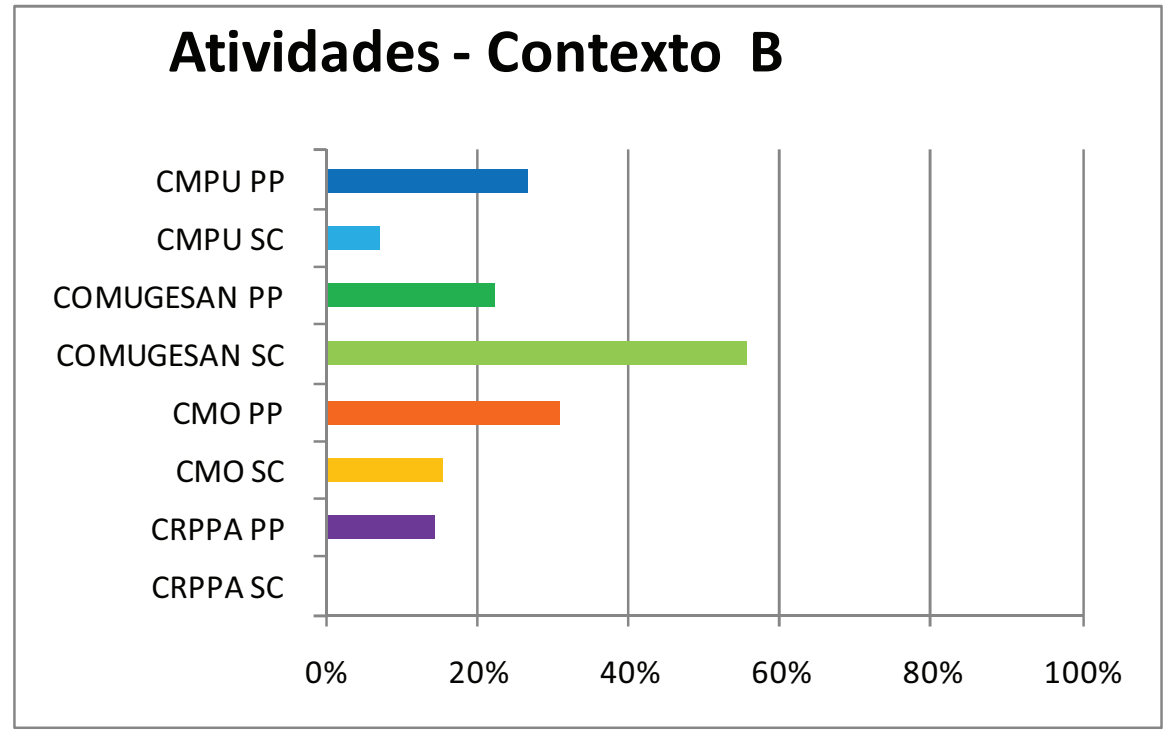

Gráfico 12: Atividades - Contexto B

Fonte: Vendramini, 2010.

Atividades - Contexto C: aqui estão as atividades explicitamente ligadas às políticas públicas do município; 


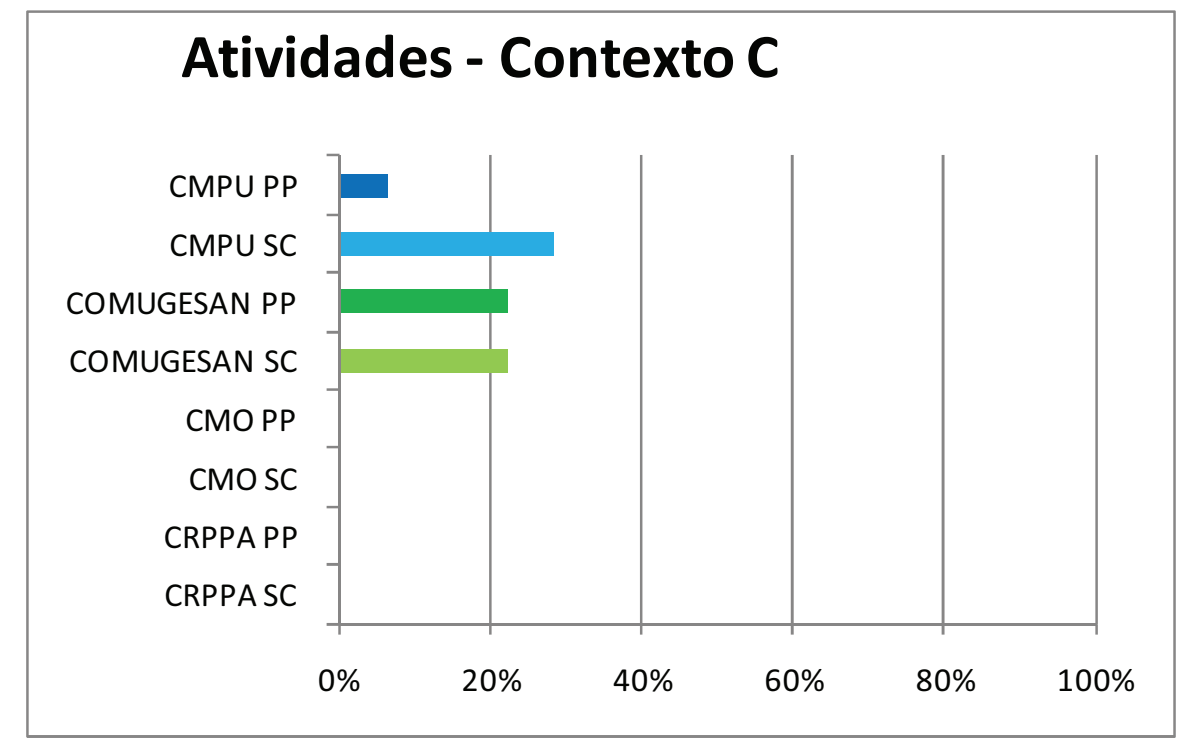

Gráfico 13: Atividades - Contexto C

Fonte: Vendramini, 2010.

Atividades - Contexto $\mathrm{D}$ : estas atividades estão relacionadas à representação, tanto dos interesses do governo, quanto da sociedade civil organizada. Aqui estão englobadas respostas como: representar os interesses do governo e buscar e levar informação entre o poder público e os representados;

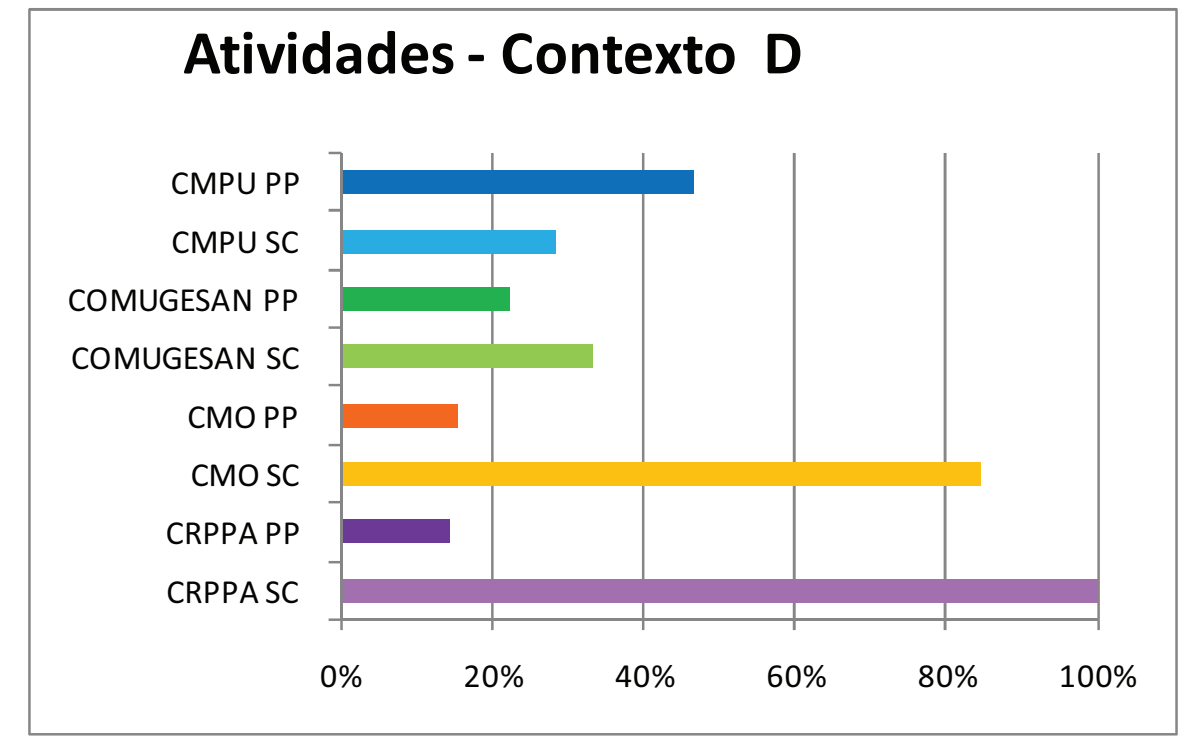

Gráfico 14: Atividades - Contexto D

Fonte: Vendramini, 2010. 
Atividades - Contexto E: estas são as respostas relacionadas com a fiscalização realizada pela sociedade civil sobre as ações do poder público;

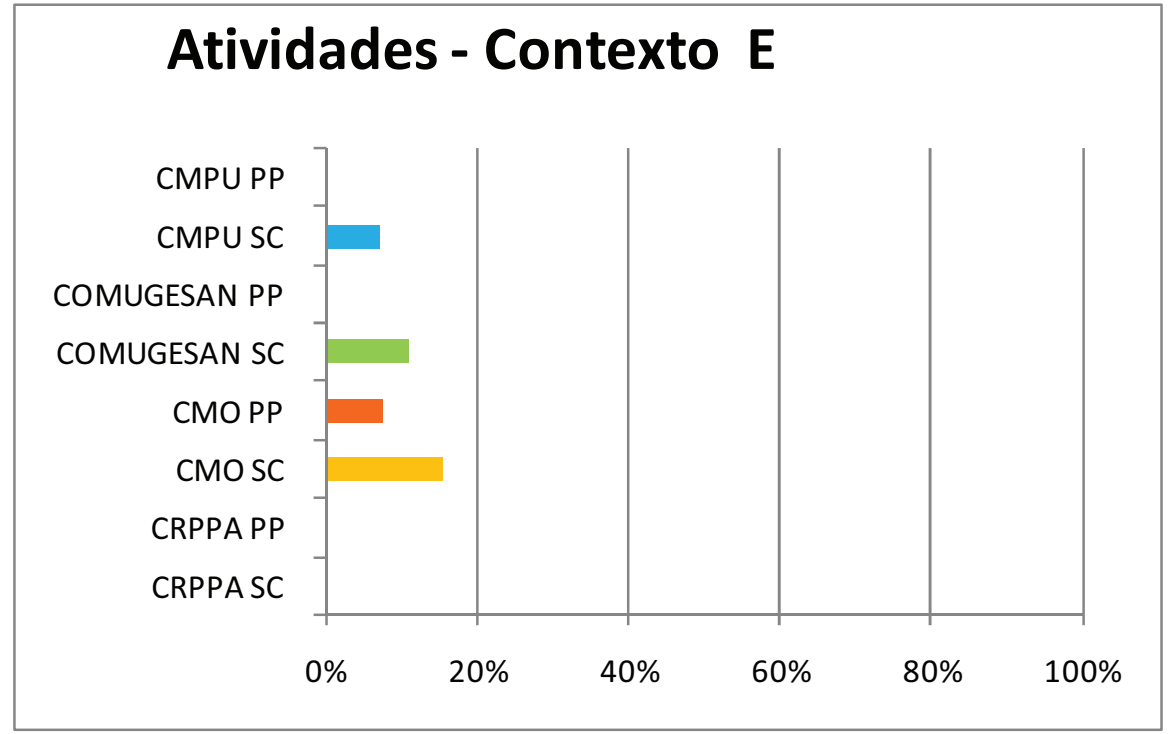

Gráfico 15: Atividades - Contexto E

Fonte: Vendramini, 2010.

Atividades - Contexto F: estas são as repostas que posicionam os conselheiros do poder público como técnicos e conhecedores da máquina pública que dão apoio técnico ao trabalho no conselho;

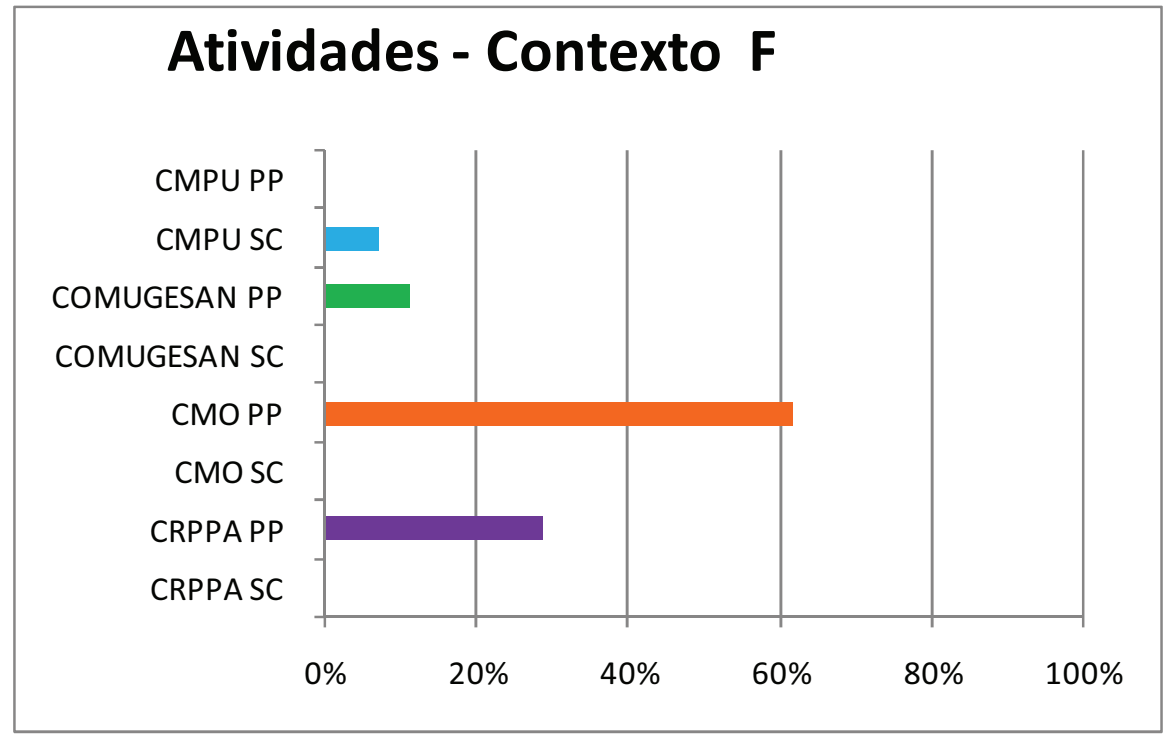

Gráfico 16: Atividades - Contexto F Fonte: Vendramini, 2010. 
Atividades - Contexto G: este contexto agrupa as menções à participação nas câmaras técnicas;

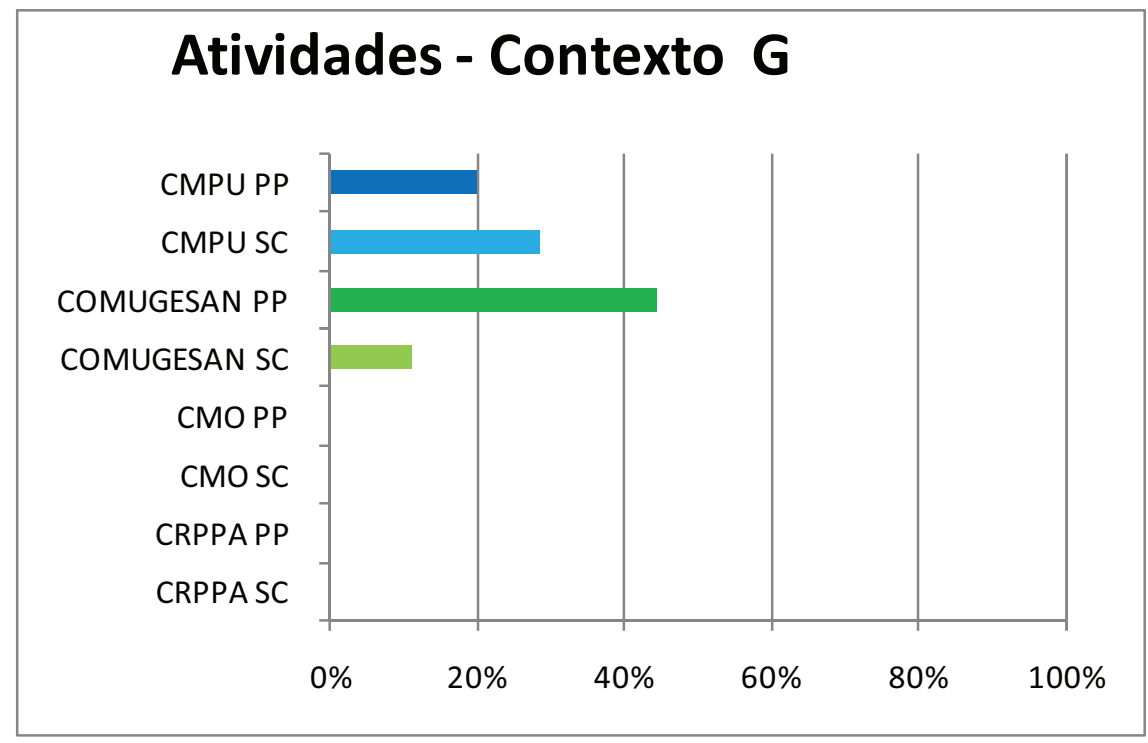

Gráfico 17: Atividades - Contexto G Fonte: Vendramini, 2010.

Atividades - Contexto H: gerenciamento de conflitos;

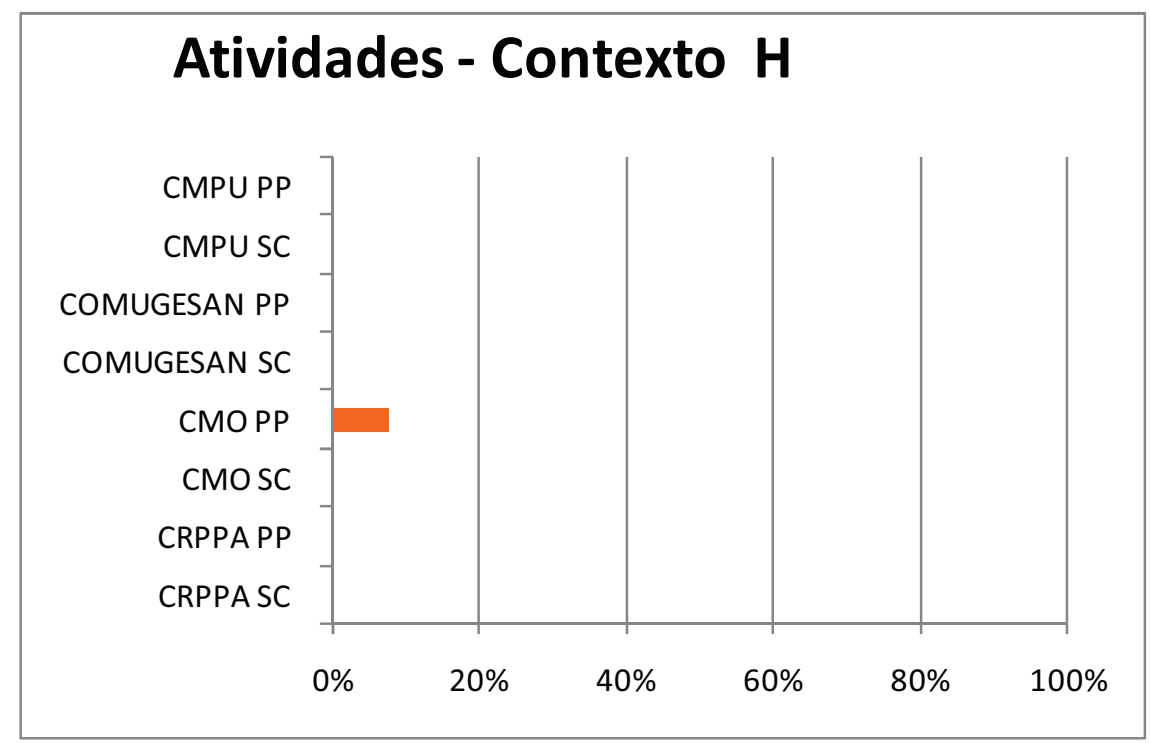

Gráfico 18: Atividades - Contexto $\mathrm{H}$ Fonte: Vendramini, 2010.

Atividades - Contexto I: relação entre conselhos. Conselheiros que participam de mais de um conselho e que fazem a comunicação entre eles. 


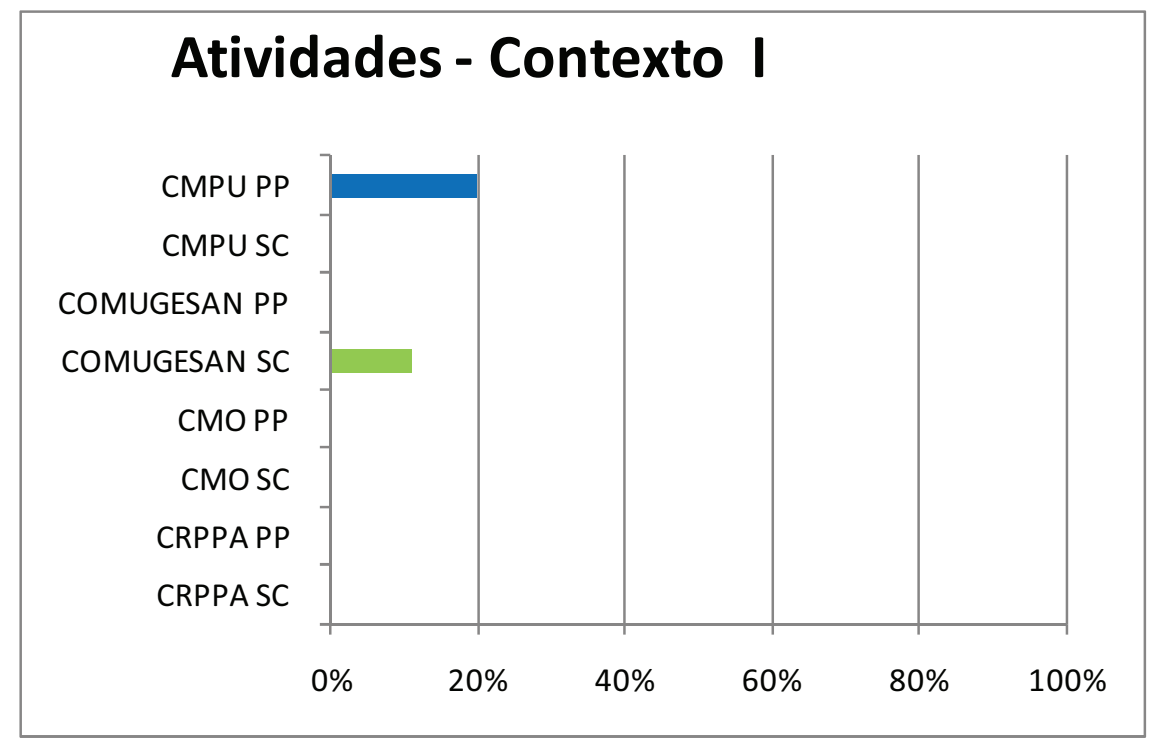

Gráfico 19: Atividades - Contexto I

Fonte: Vendramini, 2010.

De todas as atividades descritas pelos entrevistados, a de representação (Contexto D) foi a mais evidentemente caracterizada. Em todos os conselhos e representações ela esteve bastante presente, mas entre os conselheiros da sociedade civil do CMO e do CRPPA ela foi praticamente unânime. $O$ contraponto é a prevalência de respostas que definem as atividades de fornecer apoio técnico e conhecimento da máquina do governo para os membros da sociedade civil, explicitada nas respostas dos conselheiros do poder público tanto do CMO, quanto do CRPPA (Contexto F).

Como não poderia deixar de ser, as atividades relacionadas diretamente com as políticas públicas estão concentradas no CMPU e no COMUGESAN, haja vista que são os conselhos com esta função (Contexto $C$ ). O que causa estranheza é a baixa freqüência com que esta atividade aparece nas respostas dos conselheiros. Além da gestão das políticas públicas, outra atividade que é exclusiva destes é a participação nas câmaras técnicas (contexto G).

As atividades burocráticas foram expressivamente citadas em todos os conselhos. O CMO foi o que menos mencionou estas atividades na 
pesquisa (Contexto A). As atividades que representam sua dinâmica interna, como discutir ou colaborar também aparecem em todos os conselhos, com exceção para a sociedade civil do CRPPA, onde não é citada e com destaque para a sociedade civil do COMUGESAN, onde é citada por mais da metade dos conselheiros.

O papel de fiscalização da ação pública é muito pouco citado pelos conselheiros. No CRPPA ele não é mencionado por ninguém e apenas no CMO é lembrado por conselheiro do poder público (Contexto E).

Apenas um conselheiro do poder público do CMO mencionou o gerenciamento de conflitos como atividade (Contexto $\mathrm{H}$ ) e poucas foram as citações de comunicação entre conselhos (Contexto I) citadas nas entrevistas.

\subsubsection{Questão 09 • As Principais Vantagens Decorrentes da Existência do} Conselho

A questão número nove da entrevista é: "Pela sua experiência, quais as principais vantagens decorrentes da existência do conselho?" O objetivo desta questão é levantar quais as contribuições reais da existência de cada conselho para a gestão municipal, através dos conselheiros do poder público e, para a sociedade civil, também, através de seus representantes.

\section{CMPU · poder público}

Para os representantes do poder publico do CMPU, os aspectos positivos da existência do conselho mais citados são a participação e a manutenção de um canal de diálogo. Cada um destes dois itens foi dito por seis conselheiros (50\%). A transparência que o conselho proporciona foi 
lembrada por cinco entrevistados (42\%) e o controle social por três (25\%). Todos estes são elementos da democracia participativa e os conselheiros do governo do CMPU os valorizaram nas entrevistas.

Alguns outros elementos foram lembrados pelos membros do conselho e também são relevantes para o processo democrático, como: a oportunidade de realizar o que interessa para o cidadão; permitir que a sociedade civil participe de processos de deliberação; o fato de o poder público deixar de impor decisões à sociedade civil; a transferência de responsabilidade do governo para a sociedade e, por fim, o aspecto de formação para a cidadania que a participação em conselho promove.

CMPU $\cdot$ sociedade civil

Para os conselheiros do CMPU da sociedade civil, a existência de um canal de diálogo foi o item mais lembrado, totalizando seis (42\%) membros do conselho. Quatro (31\%) conselheiros mencionaram a participação como um ponto positivo da existência do conselho e outros quatro (31\%) citaram que o órgão abre a oportunidade para o poder público fazer o que o cidadão deseja.

A gestão democrática foi citada por apenas dois (15\%) entrevistados e o controle social e a cidadania, por um conselheiro cada $(8 \%)$.

É importante notar, que três conselheiros acreditam que, caso não houvesse conselho, não existiria gestão urbana ou plano diretor:

\footnotetext{
"Se não tivesse o conselho, a desordem era total na cidade, cada um fazia o que queria fazer e em um segundo virava bagunça [...]."

"Grande, porque nós tínhamos em Santo André uma cidade praticamente desordenada, sem planejamento nenhum [...]."
} 
CMPU

No CMPU a freqüência que alguns itens foram mencionados pelos conselheiros do poder público e da sociedade civil foi muito parecida. A oportunidade de participação, o canal de diálogo ${ }^{49}$ e a gestão democrática apareceram com freqüência muito próxima nos dois setores. Porém, a sociedade civil citou mais vezes o fato de que, com a existência do conselho, o governo trabalha mais próximo daquilo que o cidadão deseja, e, por outro lado, os membros do poder público citaram com mais freqüência o fato de existir um controle social através do mesmo.

Outro aspecto relevante é que 5 (42\%) conselheiros do poder público consideram que o conselho atribui transparência à gestão e que isso é um fato positivo, mas, nenhum conselheiro da sociedade civil citou transparência.

\section{COMUGESAN · poder público}

Entre os conselheiros do COMUGESAN que trabalham no governo, nove deram respostas válidas a esta questão e apontaram com mais freqüência a manutenção de um canal de diálogo (33\%) como ponto positivo a existência do conselho. Foram citados por dois conselheiros (22\%), o controle social exercido pelo do conselho e a abertura para que o poder público faça o que o cidadão deseja. Outras respostas foram dadas por apenas um conselheiro (11\%), as quais seguem: o conselho organiza o setor de maneira coerente e sustentada; é uma forma de somar esforços entre sociedade civil e poder público; e é um "termômetro da cidade":

\footnotetext{
"Eu acho que o planejamento, a priorização das ações, ele passa a ser um termômetro da cidade. Como ele é representado por vários seguimentos, né, da sociedade civil, passa a ser um termômetro das questões que estão sendo discutidas."
}

${ }^{49}$ Assis (2009) não quantifica sua análise, mas apresenta resultados semelhantes. 


\section{COMUGESAN $\cdot$ sociedade civil}

Os representantes da sociedade civil no COMUGESAN também deram nove respostas válidas para esta pergunta, e, a mais freqüente foi que o conselho está associado à gestão democrática (33\%). Reiterando isto, dois participantes (22\%) citaram que o mais importante é a participação e outros dois que é a manutenção de um canal de diálogo entre poder público e sociedade civil. Outra resposta que apareceu $22 \%$ das vezes é que o conselho tem um papel de formador do cidadão.

"A principal vantagem é a conscientização mesmo. Você está formando uma massa crítica, né, os conselheiros [...] Como há alternância de conselheiros você está formando uma massa crítica prá cidade. É importante por isso."

"Eu acho que este conselho [...] tem um papel fundamental, eu acho, inclusive na educação da comunidade a respeito das questões ambientais."

Entre os conselheiros da sociedade civil, apenas um (11\%) respondeu que o conselho tem o papel de informar, e outro, que ele tem 0 papel de levar o órgão público a fazer o que os cidadãos querem.

\section{COMUGESAN}

No COMUGESAN, o estabelecimento de um canal de diálogo entre sociedade civil e poder público foi o item mais lembrado (28\%). O outro aspecto que aparece tanto entre os conselheiros do poder público e os da sociedade civil é a abertura para que o órgão público faça o que a sociedade deseja (17\%). Todas as demais respostas foram exclusivas do poder público ou da sociedade civil.

As respostas da sociedade civil ficaram mais focadas no aspecto democrático da existência do conselho, o que incluiu gestão 
democrática ${ }^{50}$, participação e formação do cidadão. As dos conselheiros do governo ficaram divididas entre vários aspectos como a organização do setor e o controle social das ações públicas.

CMO * poder público

Entre as 12 respostas válidas do poder público do CMO, a mais freqüente foi que a principal vantagem da existência do conselho é permitir que o poder público faça o que a população deseja, e foi dada por cinco conselheiros (42\%). A gestão democrática e a participação foram citadas por três membros do conselho (25\%). Dois (17\%) conselheiros falaram do papel que exerce no desenvolvimento da cidadania, outros dois (17\%), ressaltaram que a participação faz com que o cidadão passe a pensar na cidade como um todo. A transparência e o controle social exercido através do conselho também foram citados por dois conselheiros cada.

"Tentativa de inserir as discussões de projeto de cidade na comunidade."

O papel formador de cidadania do conselho foi lembrado por um conselheiro ( $8 \%)$ do poder público. Outro aspecto também citado por apenas um conselheiro é o espaço para que a sociedade civil possa deliberar sobre os assuntos da cidade.

\begin{abstract}
"[...] não só eleger seu prefeito, seu representante na eleição e depois achar que ele tem que resolver tudo, quer dizer, é uma forma, não só de acompanhar, mas também de ajudar a decidir onde tem que ser investido."
\end{abstract}

CMO- sociedade civil

Entre os conselheiros da sociedade civil no CMO, a maioria das respostas mencionou (sete conselheiros - 47\%) que a principal

${ }^{50}$ Nunes (2009) enfatiza que este aspecto só aparece na sociedade civil . 
vantagem do CMO é que, através do conselho o governo executa o que a população necessita. A participação e a gestão democrática também foram bastante lembradas, cada um por quatro membros do conselho (27\%). Três (20\%) conselheiros falaram da transparência que o conselho promove e três (20\%) que é um canal de diálogo entre poder público e sociedade civil. A promoção da cidadania, o papel formativo que o mesmo exerce sobre os cidadãos e 0 fato de os cidadãos passarem a pensar na cidade foram lembrados por apenas um conselheiro $(7 \%)$ cada.

"É exatamente o que eu disse no início, é o olhar da população, é um outro ângulo de visão [...]."

Uma reposta que só aparece neste conselho, e que foi citada duas vezes de forma distinta, é o fato de o conselho diminuir as práticas clientelistas no município. Isto pode ser notado nas duas respostas que seguem:

"[...] tirar um pouco aquele clientelismo de vereador, né. Então não é uma pessoa que está pedindo só pra certo vereador. É uma comunidade inteira que está pedindo aquilo, né. Então é um pensamento da comunidade."

"É muito importante porque nós tivemos aí, está certo, em governos anteriores, outro tipo de governo que não é o governo participativo. Porque na verdade este é um canal participativo, tá, um canal popular de participação. Em épocas passadas você ficava com uma demanda no bairro, existia a época da sociedade amigo de bairro, e o presidente da sociedade era amigo do vereador, o vereador era amigo do presidente da câmara e o presidente da câmara era amigo do prefeito. Você tinha um triângulo e existiam os abaixo-assinados. Prá você conseguir melhorar o teu bairro era esse o procedimento. [...] O que é que muda em relação ao o conselho municipal de orçamento e o orçamento participativo? É que você faz uma marcação nos bairros, num conjunto de bairros de cada região, do que tem pra ser feito lá, e aí você vê essa condição de atender ou não a demanda sem 
a necessidade de eu estar preso a político eu como cidadão [...] posso ir lá, dar minha opinião e de repente eu vejo o assunto passar na minha porta [...]."

$\mathrm{CMO}$

No CMO houve certo alinhamento entre o poder público e a sociedade civil quanto às vantagens expostas nas respostas. Nestes dois segmentos houve uma predominância de respostas (12 - 44\%) que apontam o fato de o governo realizar projetos que atendam as necessidades do cidadão como principal vantagem do conselho. A Participação foi colocada por oito (30\%) entrevistados, e, tanto a transparência, quanto a gestão democrática, por seis (22\%) cada uma. Vários outros itens foram lembrados, como expressa o texto acima.

CRPPA $\cdot$ poder público

O CRPPA teve sete conselheiros do poder público que deram respostas válidas para esta questão. A vantagem decorrente da existência do conselho mais citada (43\%) foi a de se estabelecer um canal de diálogo entre poder público e sociedade civil $^{51}$.

"[...] sempre uma experiência de realmente estar próximo de quem a gente presta serviço né, eu trabalho há muito tempo na prefeitura e em outras áreas era sempre, não tinha essa proximidade com quem que a gente trabalha, pra quem a gente presta serviço né, eu trabalhava numa área que eu ficava longe do serviço que eu executava e isso é uma forma diferente e é melhor [...]."

As respostas dadas pelos representantes do governo no conselho foram bem esparsas. Dois (29\%) conselheiros citaram o fato fazer o que o cidadão quer e outros dois $(29 \%)$ ressaltaram que, trabalhar com o

51 Para Cezare (2009) a maior vantagem da existência do conselho para os membros do poder público é a proteção ambiental e a politização da população. 
conselho tem a vantagem de ser parte de uma gestão democrática. Várias outras respostas foram citadas apenas por um conselheiro, como: a transparência, a cidadania, o compartilhamento do poder entre poder público e sociedade civil, a formação do cidadão que decorre de sua participação ${ }^{52}$ e, por fim, o conselho foi citado como uma forma de marcar a presença da prefeitura na região, que até recentemente era alvo de disputa entre Santo André e duas municipalidades vizinhas.

CRPPA $\cdot$ sociedade civil

Entre os membros do CRPPA que são representantes da sociedade civil houve a maior freqüência de resposta da pesquisa. Todos os conselheiros afirmam que uma das principais vantagens decorrentes da existência do conselho é a abertura de um canal de diálogo ${ }^{53}$.

"É a nossa maior vantagem é a população estar próxima aos governantes, essa é a maior vantagem, porque queira ou não queira eles têm que abrir a porta pra responder pra gente. E se você não faz parte desse Conselho você toma um chá de cadeira e ninguém te atende. A maior vantagem do Conselho é isso. [...] E eu acredito que essa nova gestão tem que manter o Conselho porque 0 Conselho é o elo entre a população e a administração."

"Olha eu acho que só em ter o Conselho, só em a gente tá se reunindo, sabendo o que acontece na comunidade inteira, o que os outros conselheiros levam né, o que a prefeitura pretende, manter a gente informado, só isso aí já vale a pena ter o Conselho né e o resto a gente conquista com a força né, com a experiência de cada um, com a vontade de cada um."

"Então eu acho que é assim, o... o morador ele tem condições nessas reuniões de chegar pedir e conversar e

52 Cezare (2009) considerou este aspecto como politização da população.

${ }^{53}$ Análise corroborada pelo trabalho de Cezare (2009). 
pra ver se a gente consegue né arrumar as coisas melhores pro bairro."

No CRPPA, os conselheiros da sociedade civil também deram duas outras respostas. Dois conselheiros (33\%) citaram a participação como ponto positivo da existência do conselho e outros dois falaram do fato de que, através dele, a prefeitura pode realizar o que o cidadão deseja.

CRPPA

Somando-se todos os conselheiros do CRPPA, a resposta mais presente é que o conselho funciona como um canal de diálogo entre poder público e sociedade civil (69\%). Com a presença do conselho, o governo tende a atender as demandas dos cidadãos foi resposta citada por quatro conselheiros (31\%).

\section{Considerações}

Depois das análises individuais por conselhos e setores, foram identificados sete contextos principais que estão quantificados na tabela 4 e expressas nos gráficos 20 a 26 que se seguem:

Tabela 4: vantagens da existência do conselho " contextos

\begin{tabular}{|c|c|c|c|c|c|c|c|c|}
\hline & $\begin{array}{c}\text { respostas } \\
\text { válidas }\end{array}$ & $\begin{array}{l}\text { Vantagens } \\
\text { Contexto A }\end{array}$ & $\begin{array}{l}\text { Vantagens } \\
\text { Contexto B }\end{array}$ & $\begin{array}{l}\text { Vantagens } \\
\text { Contexto C }\end{array}$ & $\begin{array}{l}\text { Vantagens } \\
\text { Contexto D }\end{array}$ & $\begin{array}{l}\text { Vantagens } \\
\text { Contexto } \mathrm{E}\end{array}$ & $\begin{array}{l}\text { Vantagens } \\
\text { Contexto F }\end{array}$ & $\begin{array}{l}\text { Vantagens } \\
\text { Contexto G }\end{array}$ \\
\hline CMPU PP & 15 & 12 & 1 & 1 & 1 & 1 & 5 & 3 \\
\hline CMPUSC & 13 & 8 & 0 & 0 & 1 & 4 & 0 & 1 \\
\hline COMUGESAN PP & 6 & 3 & 1 & 0 & 0 & 2 & 0 & 2 \\
\hline COMUGESAN SC & 9 & 5 & 0 & 0 & 2 & 1 & 0 & 0 \\
\hline CMO PP & 12 & 5 & 2 & 1 & 1 & 5 & 2 & 2 \\
\hline CMO SC & 15 & 9 & 0 & 2 & 3 & 7 & 3 & 0 \\
\hline CRPPA PP & 6 & 5 & 1 & 0 & 1 & 2 & 1 & 0 \\
\hline CRPPA SC & 7 & 0 & 0 & 2 & 0 & 0 & 3 & 2 \\
\hline
\end{tabular}

Fonte: Vendramini, 2010.

Vantagens - Contexto A: a principal vantagem da existência do conselho diz respeito à democracia participativa. Neste contexto foram agrupados significados como gestão democrática, participação, canal de diálogo ou "não haver imposição por parte do governo"; 


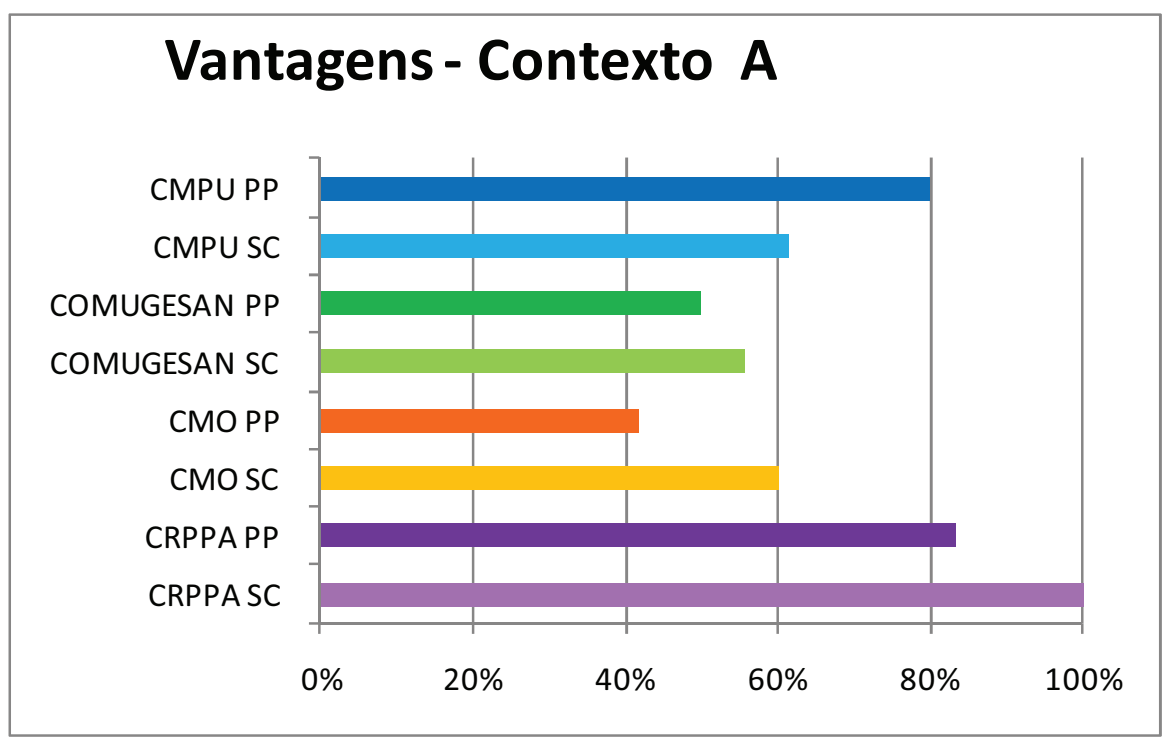

Gráfico 20: Vantagens - Contexto A

Fonte: Vendramini, 2010.

Vantagens - Contexto $\mathrm{B}$ : aqui se ressalta 0 compartilhamento efetivo de poder, identificado por expressões como: soma de esforços, transferência de responsabilidades e compartilhamento de poder;

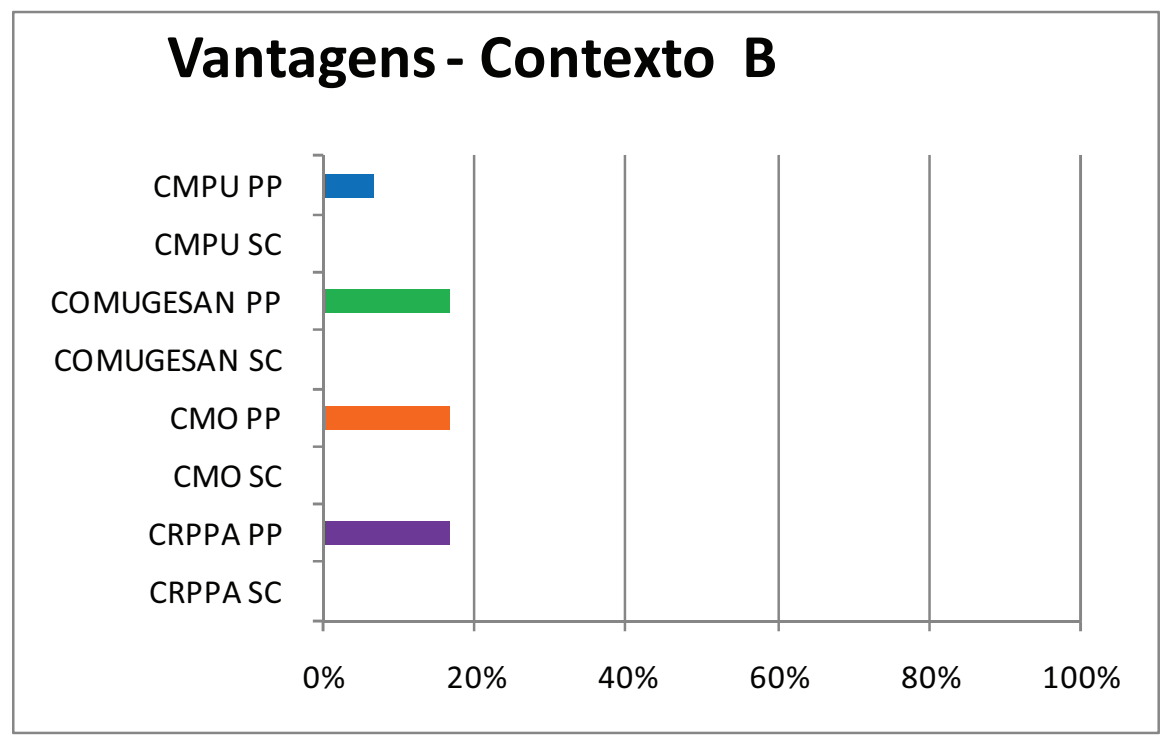

Gráfico 21: Vantagens - Contexto B Fonte: Vendramini, 2010. 
Vantagens - Contexto C: agrupou-se aqui as respostas que explicitam a participação da sociedade civil na tomada de decisão, a deliberação;

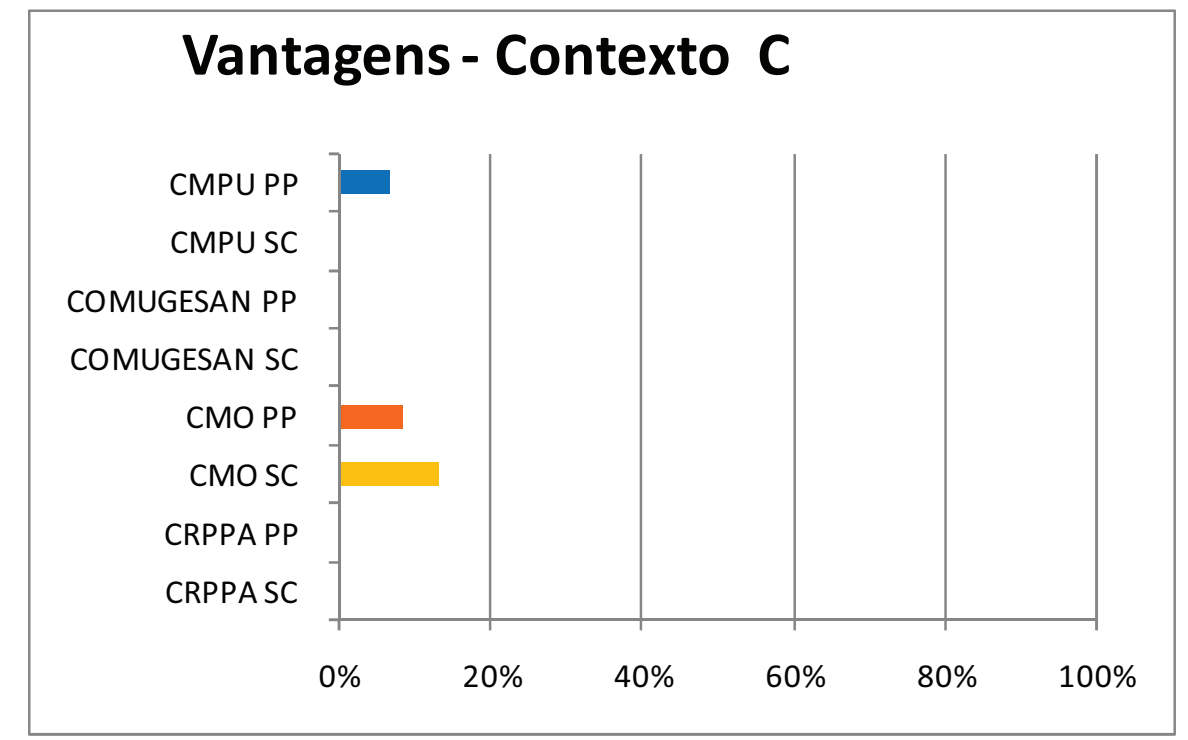

Gráfico 22: Vantagens - Contexto C Fonte: Vendramini, 2010.

Vantagens - Contexto D: neste contexto estão as respostas que indicam que o conselho tem um papel de formação sobre da cidadania, identificada por frases como: o cidadão passa a conhecer seus direitos e deveres, passa a conhecer e a se interessar pela cidade, forma o cidadão ou, simplesmente, cidadania; 


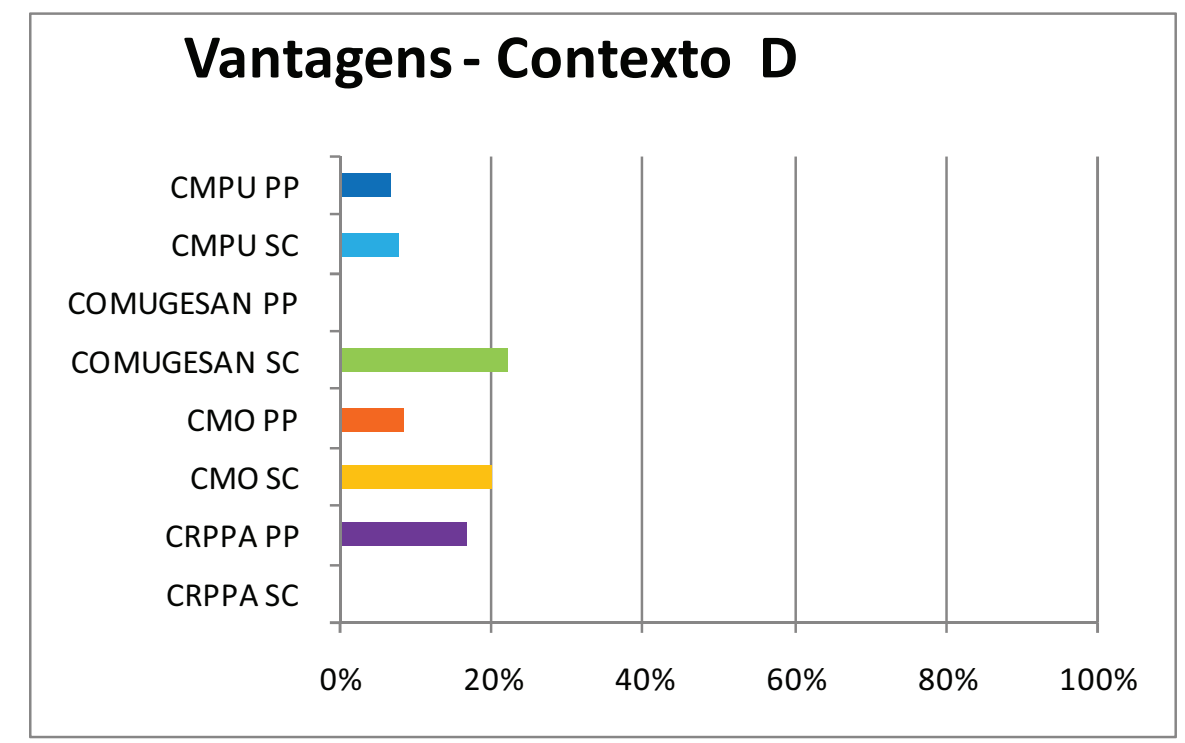

Gráfico 23: Vantagens - Contexto D

Fonte: Vendramini, 2010.

Vantagens - Contexto E: neste estão as indicações de que, através do conselho, pode-se levantar os interesses do munícipe e agir de acordo com eles, de forma a potencializar o conhecimento do "lócus" que o morador tem do seu bairro e da cidade;

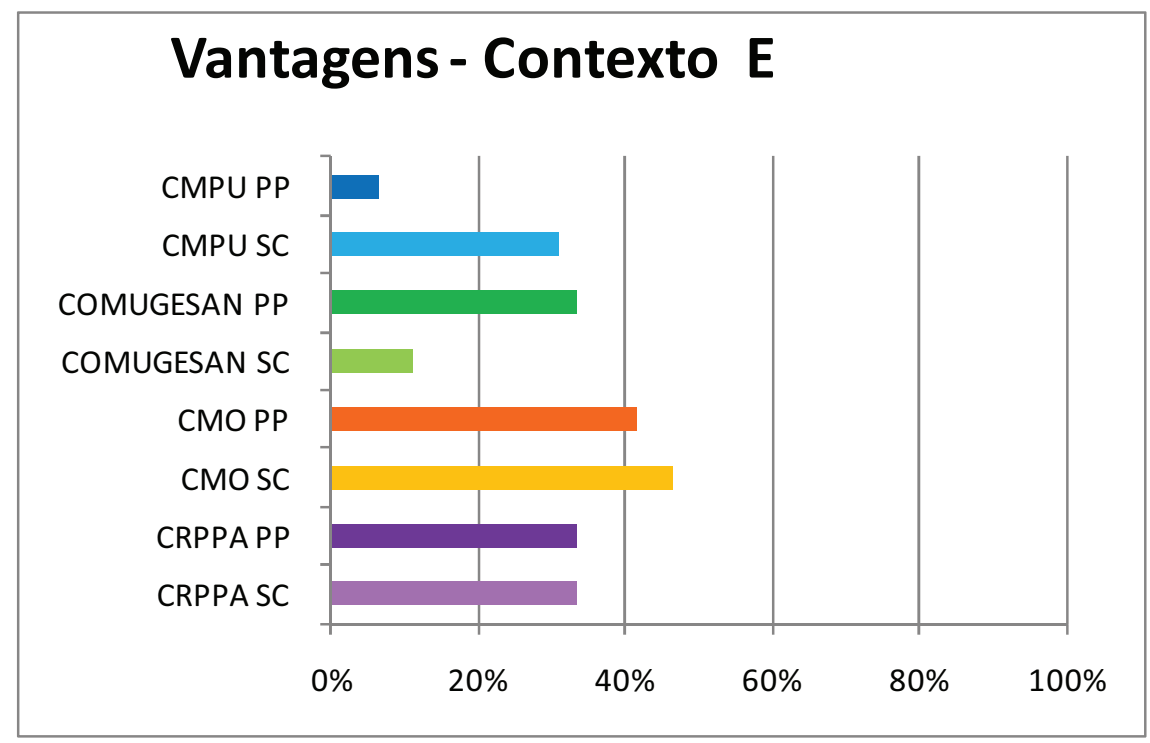

Gráfico 24: Vantagens - Contexto E Fonte: Vendramini, 2010.

Vantagens - Contexto F: transparência, informação; 


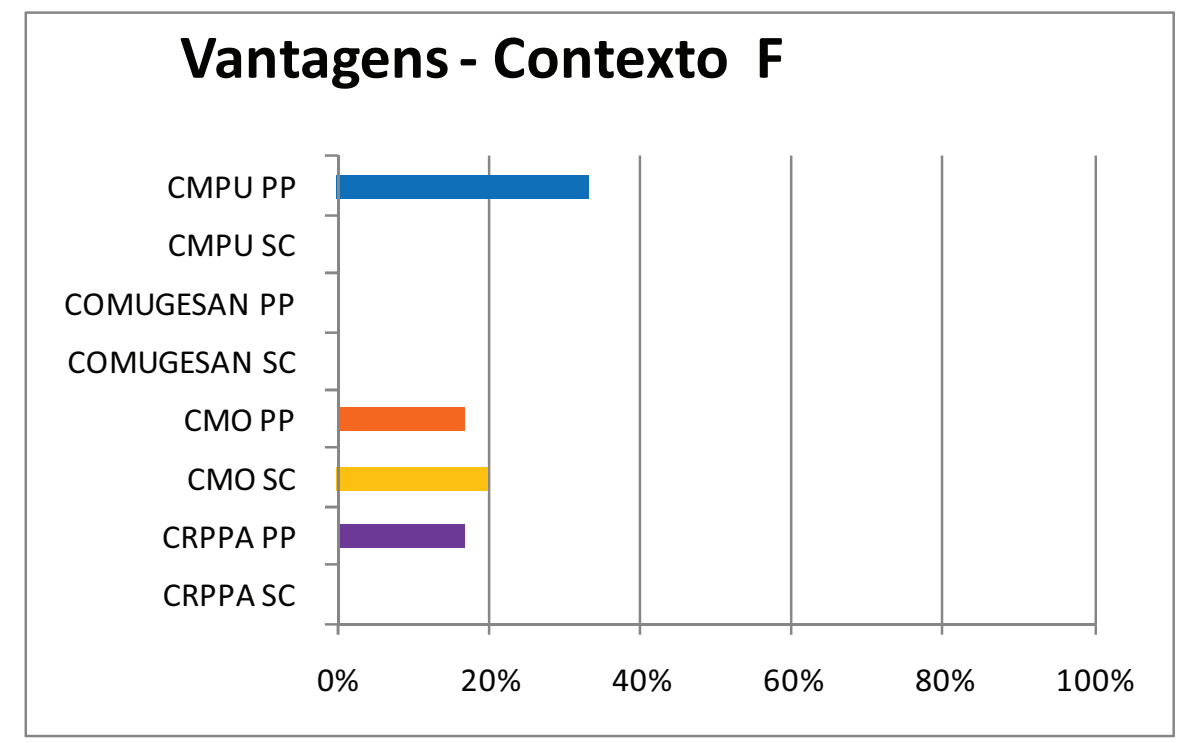

Gráfico 25: Vantagens - Contexto F

Fonte: Vendramini, 2010.

Vantagens - Contexto G: controle social sobre as ações do poder público.

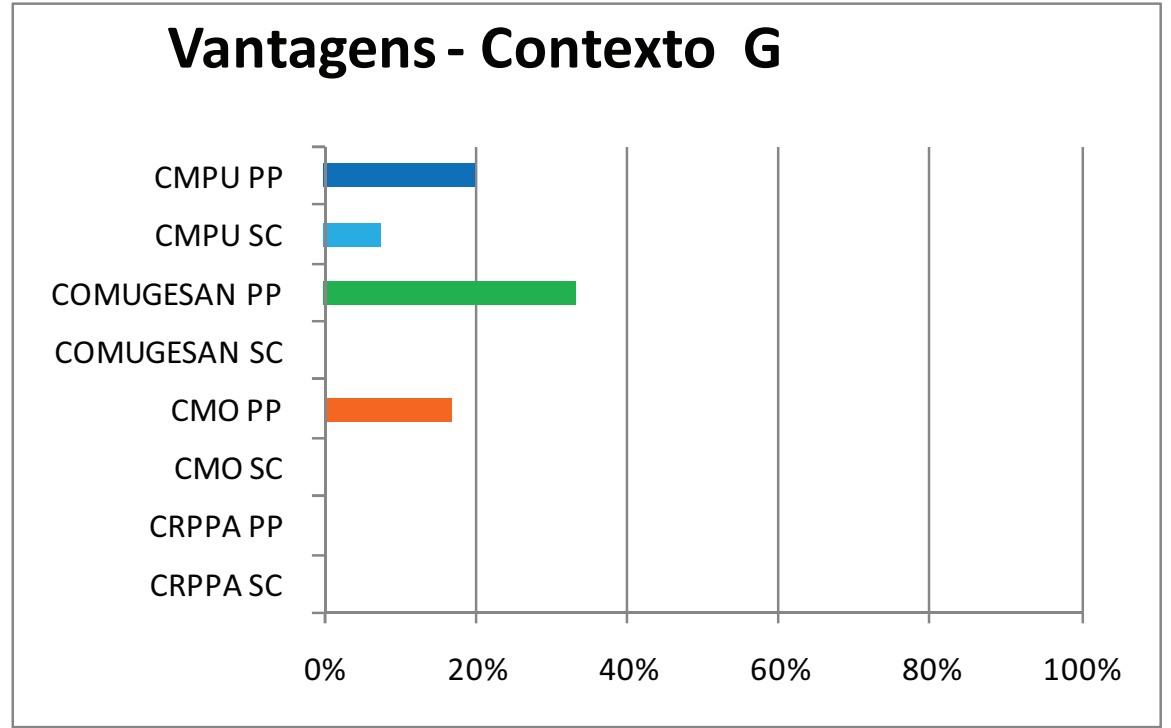

Gráfico 26: Vantagens - Contexto G

Fonte: Vendramini, 2010.

Ao analisar os gráficos apresentados, torna-se evidente a predominância das respostas que compõem o Contexto $A^{54}$, isto é, vantagens

54 Para Assis e Vendramini (2009) esta foi a resposta mais freqüente no CMO, o que se confirma nesta análise. 
da existência do conselho. A única categoria que está presente em 100\% das respostas válidas se encaixa neste contexto (apenas seis dos oito conselheiros entrevistados deram respostas válidas para esta questão). A noção de gestão democrática, participação ou o conselho como canal de diálogo é muito forte entre os conselheiros das duas representações e dos quatro conselhos estudados.

Embora menos citado nas respostas, o Contexto $\mathrm{E}$, das vantagens decorrentes do trabalho com conselhos, também foi bastante mencionado. O conselho abre um canal para que os interesses dos munícipes e o conhecimento que apenas o cidadão tem do lugar onde vive (mora, estuda, trabalha ou se diverte) cheguem ao poder público para que este último possa agir de acordo com as necessidades da sociedade civil.

Com relação ao Contexto $F$, vale notar que os conselheiros da sociedade civil não citaram que o conselho amplia a transparência em três dos quatro conselhos. $E$, com relação ao contexto $B$, apenas membros do poder público mencionaram que o mesmo promove o compartilhamento de poder entre governo e sociedade.

Algumas respostas que apareceram em apenas um conselho/representação e que não foram agrupadas nos contextos acima foram: três membros da sociedade civil do CMPU (23\%) afirmam que, o conselho é o responsável pela existência e funcionamento da política urbana; dois membros da sociedade civil do CMO (13\%) lembram que ele evita as tradicionais manobras clientelistas; um conselheiro do poder público do CRPPA (17\%) o coloca como forma de marcar a presença da prefeitura na região. 
4.4.4 Questão 10 - As Principais Dificuldades para o Funcionamento do Conselho

A questão número dez da entrevista é: " $E$ quais são as principais dificuldades para o funcionamento do conselho?". O objetivo desta questão é levantar quais são os aspectos que podem ser alterados nos conselhos para que seu funcionamento seja mais eficiente.

CMPU • poder público

Os conselheiros do CMPU que são representantes do governo levantaram duas situações principais que dificultam o funcionamento do conselho. A primeira, lembrada por quatro (40\%) dos 10 conselheiros que deram respostas válidas é a falta de tempo, principalmente da sociedade civil, para participar mais das reuniões, pois acumulam suas atividades profissionais com as do conselho. Isto impede que se amplie o tempo de trabalho do CMPU e, às vezes, não permite que estes membros se preparem adequadamente para as reuniões. A segunda, citada também por quatro (40\%) conselheiros, diz respeito à existência de níveis muito diferentes de formação e de acesso a informação, o que, muitas vezes, prejudica também o diálogo.

"Bom, o conselho é relativamente grande, então, as pessoas trabalham durante o dia e as reuniões são durante a noite. Então requer uma dedicação grande das pessoas para participar do conselho."

"[...] o nível de formação muito diferente entre as pessoas, né, tem desde arquitetos, engenheiros, empresários, né, até pessoas que são representantes de movimentos populares, bairros, etc. e tal. Quer dizer que [...] a maneira das pessoas entenderem os problemas é muito diferente. Então existe uma dificuldade de comunicação." 
Várias outras dificuldades foram citadas por apenas um conselheiro (10\%), que seguem: falta de diálogo entre poder público e sociedade civil; falta a cultura de ver a cidade como um todo; o fato de a sociedade civil estar representada, mas não a população; falta de infraestrutura própria do conselho; dificuldades com a coordenação interna e ter havido uma resistência inicial por parte da estrutura da prefeitura.

CMPU $\cdot$ sociedade civil

Entre as dificuldades apontadas pelos representantes da sociedade civil no CMPU, quatro (31\%) conselheiros apontaram a diversidade e os conflitos, e três (23\%) citaram que a falta de tempo e o acúmulo de trabalho dificultam o funcionamento do conselho.

"Essa briga, né, da sociedade civil com o governo. Se você não acha alguma coisa certa você tem que bater de frente, né. Aí vai pra votação, [...]."

A parte técnica e a diferença de níveis de formação entre os conselheiros foi citada por dois (15\%) representantes da sociedade civil no CMPU e outros dois mencionaram a pouca participação como dificuldade no conselho.

"É a participação. Em algumas reuniões, assim, já aconteceu de não ter pessoas suficientes para por alguma coisa em destaque ou mesmo votação."

Houve três respostas que foram citadas por apenas um conselheiro: a burocracia, a alteração do que foi decidido na reunião do conselho e a vontade política.

"O conselho, eu acho que qualquer projeto que se envolva participação popular, ele só funciona de verdade se o governo quer." 
CMPU

Para os 23 conselheiros do CMPU que deram respostas válidas para esta questão, a falta de tempo e o acúmulo de trabalho foi a principal dificuldade, sendo citada por sete (30\%) deles. A diferença de nível de formação também foi mencionada tanto entre os conselheiros da sociedade civil quanto entre os do poder público, por seis (26\%) membros no total. É interessante ressaltar que os conflitos dentro do conselho foram apontados por quatro membros da sociedade civil, o que, aliás, foi a resposta mais freqüente entre estes conselheiros, e, esta mesma dificuldade não foi citada por nenhum membro do poder público.

Entre as respostas menos freqüentes, nenhuma foi mencionada nas duas representações, ou seja, as dificuldades citadas pelos conselheiros do poder público são distintas das citadas pelos da sociedade civil. Os representantes da sociedade civil sentem problemas com a burocracia, com vontade política, com a alteração do que é decidido em plenária, além de problemas com a participação. Os representantes do poder público apontam dificuldades de diálogo, falta de cultura urbana e de um olhar global sobre a cidade, falta de infra-estrutura para o conselho, a falta de representatividade da sociedade, a aparentemente superada resistência ao conselho por parte da estrutura da prefeitura no início de seu funcionamento, e dificuldades com a coordenação do conselho ${ }^{55}$.

\section{COMUGESAN · poder público}

No COMUGESAN, oito conselheiros do poder público deram respostas válidas a esta questão. Dentre eles, dois (25\%) apontaram que 0 conselho deveria ter uma amplitude maior.

\section{"Eu tenho a impressão de que o conselho, ele deveria ter uma amplitude maior."}

\footnotetext{
${ }^{55}$ Assis (2009) não quantifica sua análise, mas apresenta resultados semelhantes.
} 
"Eu acho que o conselho precisava sensibilizar mais o conjunto das entidades para participar. Me passou a impressão de que o conselho ainda está muito ligado a entidades que têm uma certa especialização em meio ambiente. Fiquei com a impressão de que se se ampliasse o conselho para outras áreas, com sindicatos de trabalhadores, organizações de estudantes, essas coisas, acho que ficaria melhor".

As demais respostas citadas foram mencionadas por apenas um (13\%) conselheiro cada: a falta de tempo e disponibilidade dos conselheiros; as diferenças de níveis de formação entre os membros; os conflitos dentro do conselho; a participação; as restrições técnicas sobre o que é decidido, e a transparência.

\section{COMUGESAN $\cdot$ sociedade civil}

Entre os membros da sociedade civil no COMUGESAN, apenas três apontaram dificuldades para seu funcionamento. Aqui não houve respostas coincidentes, portanto, cada uma representa 33\% das respostas válidas, que seguem: diferenças de nível de formação; falta de diálogo entre poder público e sociedade civil; falta de cultura urbana e de enxergar a cidade como um todo; a participação e a falta de representatividade.

"Eu acho que esta questão de não se discutir as políticas mais globais [...] dificulta. [...] Você vai no específico e acaba esquecendo à frete, ou seja, esqueceu o problema. [...] Outra coisa que é complicado também são as INGs, né. Os Indivíduos não governamentais, né. Não se replica muito e isso é um problema da sociedade civil."

\section{COMUGESAN}

Provavelmente decorrente do pouco número de respostas válidas, houve pouca coincidência de respostas entre os conselheiros do poder público e da sociedade civil. As respostas mais freqüentes foram 
citadas por dois (18\%) conselheiros. A necessidade de se aumentar a amplitude do conselho foi lembrada apenas por conselheiros do poder público. A diferença de nível de formação e as dificuldades de participação foram lembradas por um membro de cada representação no conselho.

CMO - poder público

Entre os membros do governo no $\mathrm{CMO}$, onze deram respostas válidas para esta questão. Três (27\%) apontaram a dificuldade em atrair as classes média e alta para participar do conselho. Dois (18\%) mencionaram a falta de tempo e disponibilidade para participar das reuniões, e outros dois citaram as limitações orçamentárias como dificuldade para o próprio funcionamento.

"Acho que é assim. Você consegue chegar muito mais fácil a uma população carente do que a essa população de classe média-alta que é fundamental, né, porque assim, se você quer criar uma igualdade, né, uma igualdade social, [...] Por exemplo, a gente faz reunião, né, nos vários bairros, o centro é sempre o mais esvaziado, né, por que no centro está a elite local. Isso eu acho falta, né, eu acho que as pessoas reclamam muito sem saber a realidade local. [...] porque hoje a gente só consegue atrair quem tem necessidade, mas a cidade tem que ser pensada como um todo, né, [...] a participação do público, vamos dizer, mais carente é muito maior do que quem é esclarecido, quem podia contribuir com idéias, inclusive, ou seja, quem tem a possibilidade de elaborar de uma forma mais criativa, mais sustentável, né, porque, quer queira quer não tem mais informação que essa população mais carente, né, no sentido de conseguir elaborar, né. Tem que partilhar, né."

Outras oito respostas foram lembradas pelos membros do governo no CMO, mas, cada uma delas foi mencionada por apenas um (9\%) conselheiro. Elas são: diferenças de nível de formação, entendimento e 
linguagem; participação; disputa política entre grupos; o fato de todos quererem suas demandas aprovadas; falta de informação; os limites da ação municipal; e duas repostas complementares: alguns setores da sociedade são refratários à mudança e alguns conselheiros do governo têm dificuldade de entender a participação como política de governo.

"[...] você tem setores da sociedade que são totalmente refratários a essas mudanças de paradigma, né, isso é normal, isso acontece em qualquer região. O caso especificamente do Brasil, pelo histórico que nós tivemos, pela formação da nossa sociedade, é um pouco mais complexo, né, vou te dar um exemplo muito interessante que é o seguinte. Na primeira gestão do prefeito Celso Daniel, 89-92 [1989 a 1992], quando o Celso começou a discussão do orçamento participativo, naquela época era só consultivo, não era deliberativo, saiu um editorial do jornal aqui, Diário do Grande $A B C$, falando que, ou ele não sabia o que estava fazendo, ou, sabe, ele é maluco, coisa assim em outras palavras, né [...]. Então você tem setores que são refratários que têm a imprensa na mão, às vezes o judiciário ajuda nesse sentido, né. $E$ também não basta só o executivo fazer essa mudança, a gente tem que ter maior permeabilidade nessas questões de democratização [...]."

"Eu acho que seria o entendimento por parte dos conselheiros do governo, né, enquanto projeto de governo realmente, né. A gente tem bastante dificuldade da participação dos conselheiros do governo."

CMO - sociedade civil

Entre os membros da sociedade civil no CMO, a dificuldade mais presente nas respostas foi o limite orçamentário, presente em 5 (50\%) das 10 respostas válidas. Um problema citado por dois (20\%) conselheiros diz respeito à tendência de alguns representantes da sociedade civil não quererem abrir mão de suas demandas em favor do todo. Dois (20\%) outros membros do conselho disseram que a diferença de nível de formação, e às 
vezes, a diferença de linguagem decorrente disto dificulta o entendimento de alguns conselheiros.

"É quando um do conselho ele cisma que ele quer, isto aconteceu este ano, que ele quer aquela demanda pra região dele, independente se pode ou não pode".

"Quando chega na parte técnica da coisa. Porque nós somos leigos em muitas coisas, então, quando chega na parte técnica, quando chega nos custos, quando chega na forma de isso se concretizar [...]."

"Eu acho que aí é assim, o tempo dele é muito curto e teria que ter um aprendizado. É uma coisa que a gente vem trabalhando e que é difícil e que a gente vai ter que trabalhar com isso. Eu diria que teria que ser o preparo do conselheiro. Isso é dificuldade. Porque tem conselheiro que ele não tem visão ampla e ele não sabe como tem que negociar com a prefeitura".

As demais dificuldades levantadas pelos conselheiros da sociedade civil foram citadas por apenas um de seus membros: falta de infra-estrutura e verba próprias do conselho; dificuldades com a participação; falta de transparência; dificuldades para atrair as classes média e alta para participar, a falta de mobilização. $\mathrm{O}$ fato de ser um ano político dificulta os trabalhos no conselhos e, por fim, a sociedade civil deveria se mobilizar antes do início do processo do orçamento participativo para existir mais representatividade.

CMO

Somando-se as 21 respostas válidas dos conselheiros do CMO em Santo André, o que mais se repete é o limite orçamentário, apontado por sete (33\%) membros do conselho como a maior dificuldade 
para seu funcionamento ${ }^{56}$. Quatro (19\%) conselheiros disseram ser difícil atrair para o conselho as classes média e alta para participar do orçamento participativo, uma vez que seus bairros têm poucas demandas de infraestrutura. Três conselheiros (14\%) disseram ser difícil lidar com as diferenças de nível de formação entre conselheiros e dois (10\%), um de cada setor, disseram que é a participação no conselho.

Todas as demais respostas apareceram em apenas um setor, sociedade civil ou poder público.

\section{CRPPA $\cdot$ poder público}

No CRPPA houve sete respostas válidas entre os membros do poder público. Para três $(43 \%)$ deles, a maior dificuldade para 0 funcionamento do conselho é a participação. A distância também é uma dificuldade importante para os membros daquele conselho ${ }^{57}$, pois a região é muito grande, pouco habitada e carente de transporte público. Por ser composta por dois pólos principais e distantes entre si (Vila de Paranapiacaba e os loteamentos que compõem o Parque Andreense), este foi um problema apresentado por dois (29\%) conselheiros. Outro item também citado por dois membros do governo foi a falta de representatividade dos conselheiros.

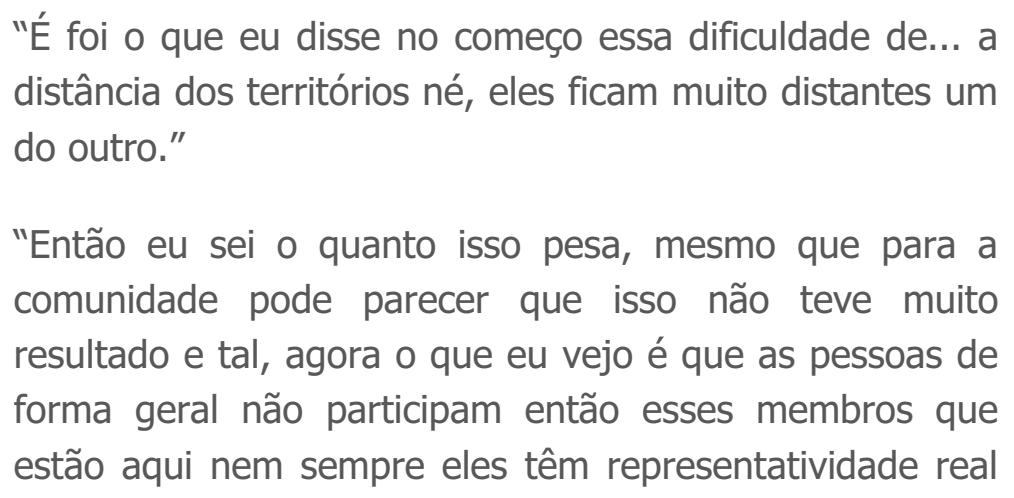
distância dos territórios né, eles ficam muito distantes um do outro."

"Então eu sei o quanto isso pesa, mesmo que para a comunidade pode parecer que isso não teve muito resultado e tal, agora o que eu vejo é que as pessoas de forma geral não participam então esses membros que estão aqui nem sempre eles têm representatividade real

\footnotetext{
${ }^{56}$ Assis e Vendramini (2009) não quantifica sua análise, mas apresenta resultados semelhantes.

${ }^{57}$ Análise corroborada pelo trabalho de Cezare (2009).
} 
na comunidade né, são as pessoas muitas vezes que têm mais disponibilidade, mais interesse, que vem lutar por causas particulares né, que a gente fala que vem pelo próprio umbigo, então essas pessoas elas muitas vezes elas não têm o crédito da própria comunidade e elas também não reproduzem isso na comunidade, elas não repercutem, elas não se, elas não se organizam fora do Conselho pra trazer uma discussão mais consolidada, pra trazer uma demanda mais forte, formatada."

Dos sete conselheiros do poder público, apenas um (14\%) respondeu cada uma das dificuldades que se seguem: os conselheiros da sociedade civil às vezes não abrem mão de um ponto na discussão e isso causa frustração; a diferença de nível de formação e de linguagem; e o fato de 2008 ter sido um ano político.

"[...] então você vai pra um debate meio que desigual né, tanto que do lado do governo tem todas as informações tem toda a capacidade técnica de fazer a discussão, a sociedade civil está sempre em desvantagem nesse sentido, e de uma certa forma acaba é... prevalecendo né a opinião da parte do governo né."

CRPPA $\cdot$ sociedade civil

Dentre a sete respostas válidas dadas pelos conselheiros representantes da sociedade civil no CRPPA, a mais freqüente foi a dificuldade que alguns conselheiros apresentam de abrir mão de causas pessoais e lidar com a frustração, mencionada por três (43\%) membros:

"É assim ó, muitas vezes a gente consegue, vai lá vê as coisas chega fala né, mas aí depois nem tudo que a gente quer eles podem fazer né. Então a dificuldade se torna aí né, um pouquinho aí."

"A dificuldade é fazer com que as idéias sejam entendidas no coletivo né, porque as pessoas às vezes são muito... tem muito o ego delas que tem que satisfazer. Às vezes 
você lutar por uma causa pra uma pessoa e no final descobre que aquela causa não é uma causa que ela entende como coletiva da comunidade, ela entende como uma coisa pessoal."

"O compromisso dos conselheiros, o compromisso de todos os conselheiros, seja o compromisso de entender a importância do Conselho e o papel que cada um tem nisso tudo, seja também limitar a disputa que existe entre as pessoas, porque acaba pessoas é... uma querendo se sobressair mais que as outras e a gente acaba fragilizado".

A falta de diálogo com a prefeitura no conselho foi citada por três $(43 \%)$ de seus membros e a dificuldade para participar por motivo de tempo ou da distância foi mencionada por outros dois (29\%).

Apenas um conselheiro sentiu dificuldade com a falta de participação e outro com alterações de decisões tomadas em reunião.

"Então tem conselheiro no plano de regularização fundiária, por exemplo, eles falam que trabalha com o povo né, eles não trabalharam com a gente, nós ia nas reuniões, mas era feito tudo do jeito deles. A proposta final quando eles fecharam o documento eles não perguntaram se nós aceitava, se nós concordava ou não, entendeu. Simplesmente mandaram, nós queria, nós eu, por exemplo, que sou vice-presidente do Conselho, queria um documento daquilo que foi discutido e eles não nos deram. Nem sabe se aquilo que foi discutido foi mandado pra lá porque eles não nos deram cópia nenhuma. Então teve o Conselho, teve reunião, várias reuniões, mas eles não nos deram documento comprovando que era aquilo que eles estão mandando pro juiz. Então... eles falam, eles chegam e falam - ah, mas foi, esse projeto foi desenvolvido com a população. Não foi, porque eles simplesmente eles chegavam nas reuniões e falavam - é assim, assim, assim, que nós vamos fazer e pronto. Eles não deixaram nós escolher, entendeu, mas alguns pontos nós conseguimos reverter, várias casas que ia ser 
demolida, que eles alegavam que existia nascente, nós fomos fazer vistoria e não existia mais nascente, viu. Mas era assim, era lá eles fizeram e pronto, nós só fomos laranja na história."

CRPPA

As dificuldades descritas quanto à participação e aos problemas relacionados com tempo e distância foram, cada um, citado por quatro (29\%) conselheiros, entre eles membros da sociedade civil e do poder público. Todas as demais dificuldades citadas foram exclusivas do poder público, tais como a falta de representatividade, ou da sociedade civil, como a intransigência de alguns conselheiros sobre suas demandas.

Considerações

Depois das análises individuais por conselhos e setores, foram identificados oito contextos principais. Os resultados foram tabulados como mostram a tabela 5 e os gráficos 27 a 34 a seguir: 
Tabela 5: dificuldades para o funcionamento do conselho - contextos

\begin{tabular}{|c|c|c|c|c|c|}
\hline & $\begin{array}{l}\text { respostas } \\
\text { válidas }\end{array}$ & $\begin{array}{c}\text { Dificuldades } \\
\text { Contexto A }\end{array}$ & $\begin{array}{c}\text { Dificuldades } \\
\text { Contexto B }\end{array}$ & $\begin{array}{c}\text { Dificuldades } \\
\text { Contexto C }\end{array}$ & $\begin{array}{c}\text { Dificuldades } \\
\text { Contexto D }\end{array}$ \\
\hline CMPU PP & 10 & 2 & 5 & 4 & 0 \\
\hline CMPU SC & 13 & 6 & 2 & 3 & 0 \\
\hline COMUGESAN PP & 8 & 1 & 1 & 2 & 2 \\
\hline COMUGESAN SC & 3 & 0 & 2 & 2 & 0 \\
\hline CMO PP & 11 & 0 & 1 & 3 & 3 \\
\hline CMO SC & 10 & 1 & 2 & 1 & 2 \\
\hline CRPPA PP & 7 & 0 & 1 & 0 & 0 \\
\hline CRPPA SC & 7 & 0 & 0 & 2 & 0 \\
\hline
\end{tabular}

\begin{tabular}{|c|c|c|c|c|c|}
\hline & $\begin{array}{l}\text { respostas } \\
\text { válidas }\end{array}$ & $\begin{array}{c}\text { Dificuldades } \\
\text { Contexto E }\end{array}$ & $\begin{array}{c}\text { Dificuldades } \\
\text { Contexto F }\end{array}$ & $\begin{array}{l}\text { Dificuldades } \\
\text { Contexto G }\end{array}$ & $\begin{array}{c}\text { Dificuldades } \\
\text { Contexto H }\end{array}$ \\
\hline CMPU PP & 10 & 0 & 0 & 2 & 0 \\
\hline CMPUSC & 13 & 0 & 0 & 3 & 0 \\
\hline COMUGESAN PP & 8 & 0 & 0 & 1 & 1 \\
\hline COMUGESAN SC & 3 & 1 & 0 & 1 & 0 \\
\hline CMO PP & 11 & 0 & 3 & 2 & 2 \\
\hline CMO SC & 10 & 0 & 3 & 1 & 5 \\
\hline CRPPA PP & 7 & 2 & 1 & 0 & 1 \\
\hline CRPPA SC & 7 & 0 & 3 & 2 & 0 \\
\hline
\end{tabular}

Fonte: Vendramini, 2010.

Dificuldades - Contexto A: neste grupo estão dificuldades internas, tais como: falta de infra-estrutura e verba próprias, dificuldades com a coordenação do conselho, conflitos dentro do conselho, debates, diversidade. 


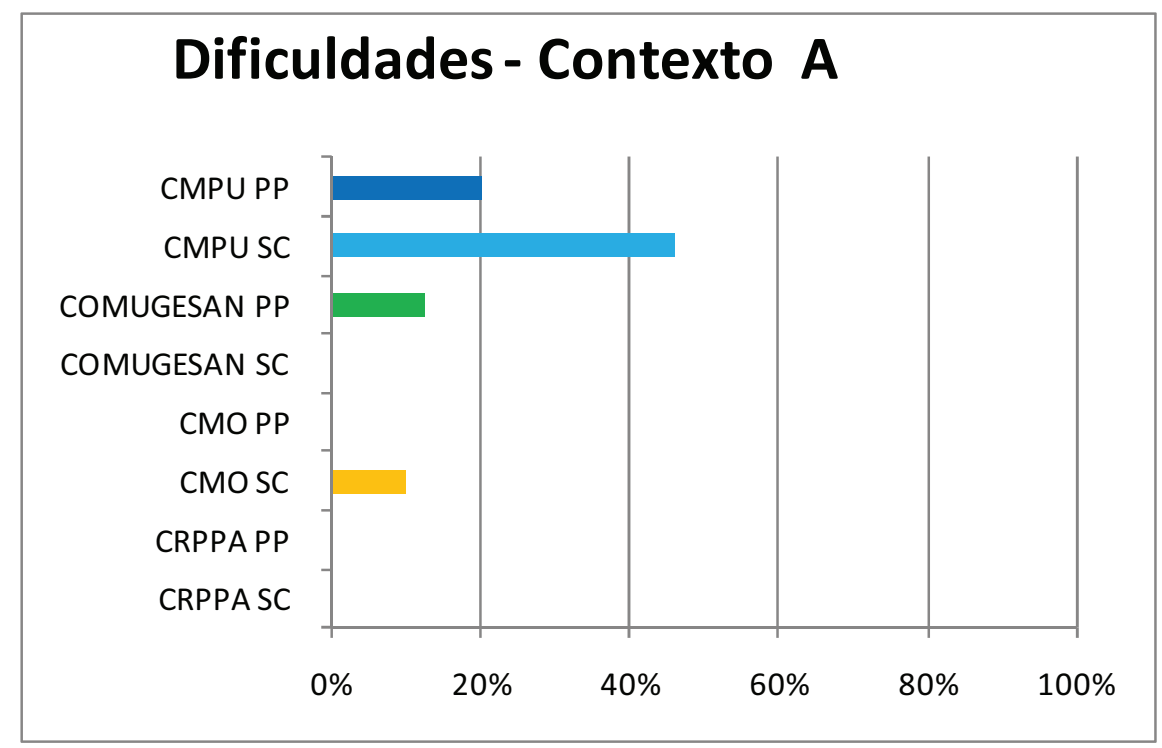

Gráfico 27: Dificuldades - Contexto A Fonte: Vendramini, 2010.

Dificuldades - Contexto B: neste conjunto, estão dificuldades relacionadas com deficiência de capacitação, tais como: diferenças de nível de formação no conselho, falta de conhecimento técnico, problemas com a linguagem utilizada, falta de cultura urbana, o não compreender a cidade como um todo.

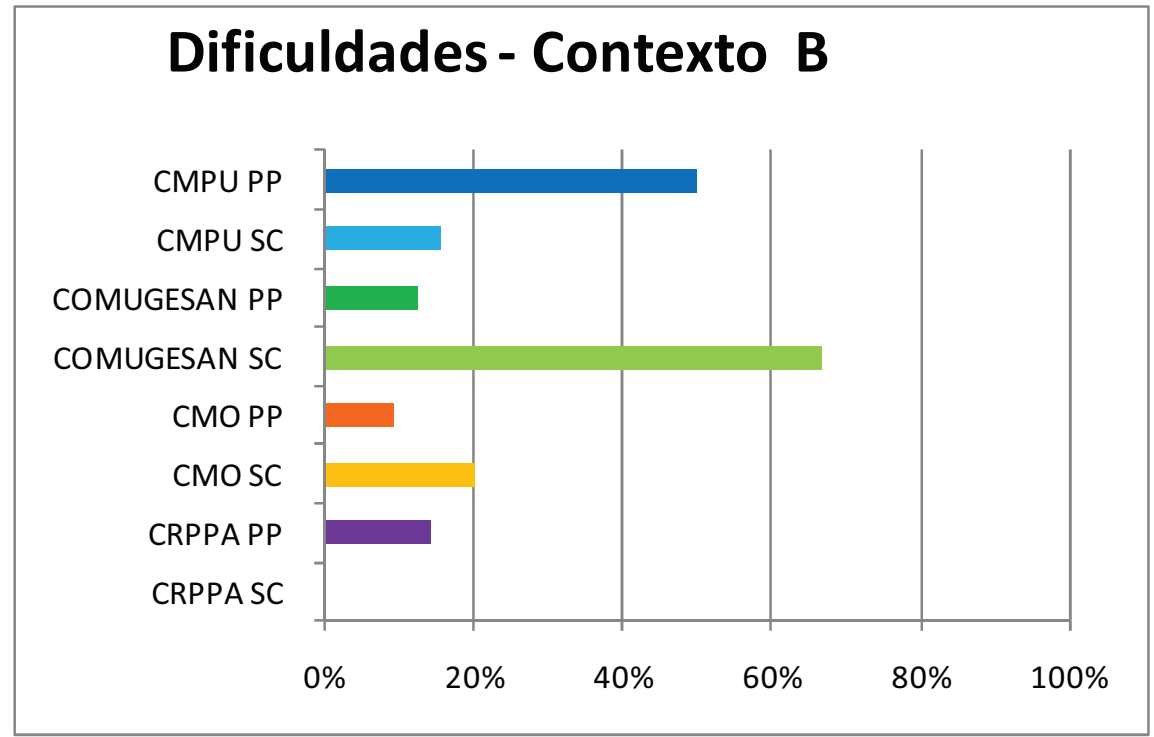

Gráfico 28: Dificuldades - Contexto B

Fonte: Vendramini, 2010. 
Dificuldades - Contexto C: aqui foram concentradas as dificuldades relacionadas à participação, incluindo falta de tempo, disponibilidade e transporte para as reuniões.

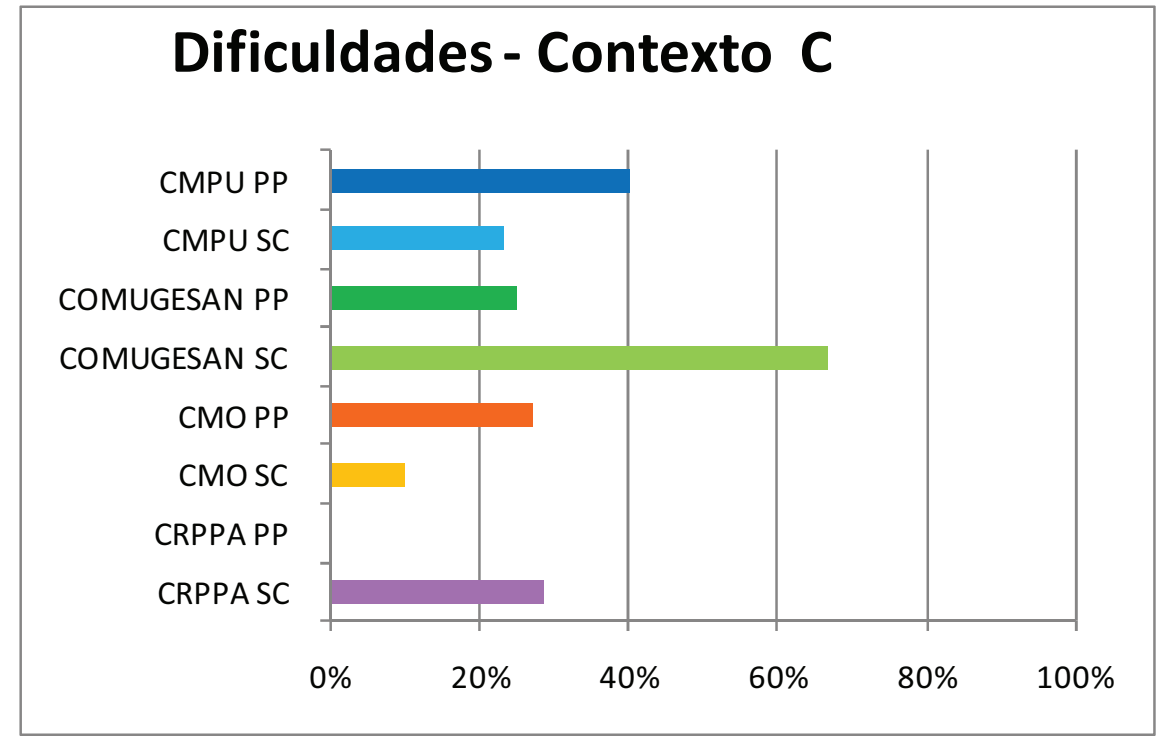

Gráfico 29: Dificuldades - Contexto C

Fonte: Vendramini, 2010.

Dificuldades - Contexto D: neste grupo foram concentradas as dificuldades relacionadas à mobilização para a participação no conselho, desde falta de amplitude dos participantes, às dificuldades de atrair as classes mais altas e diretamente falta de mobilização. 


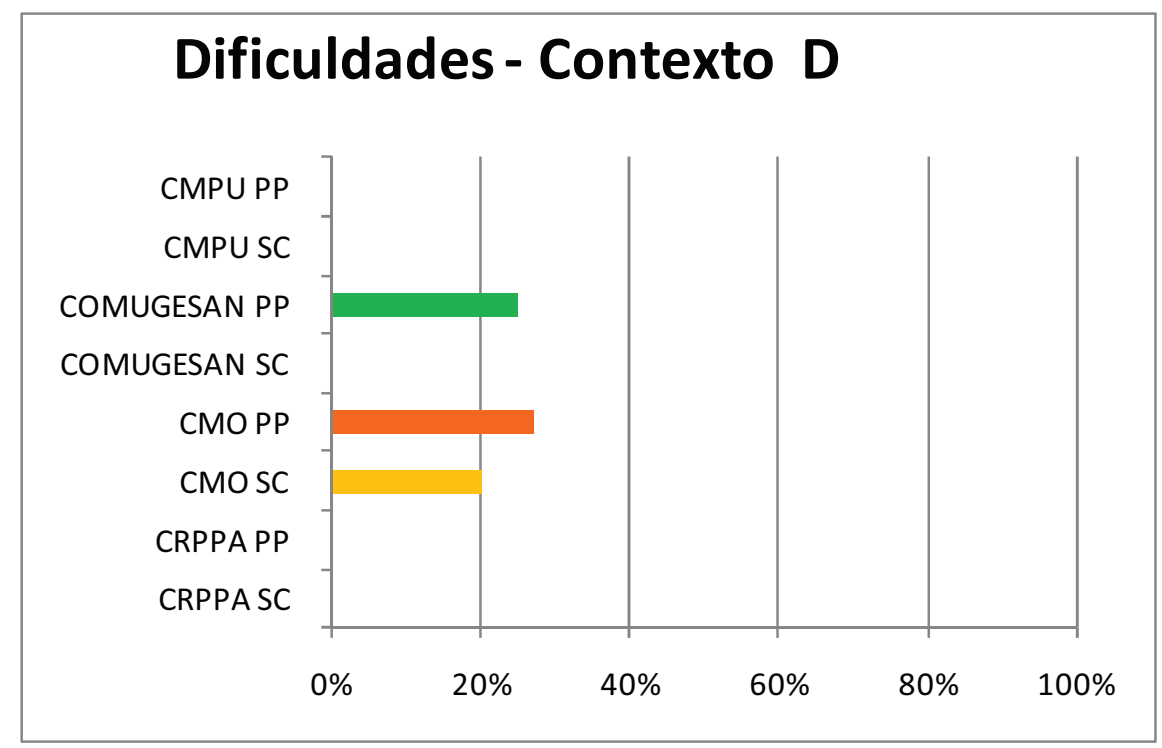

Gráfico 30: Dificuldades - Contexto D

Fonte: Vendramini, 2010.

Dificuldades - Contexto E: aqui foram concentradas a dificuldades de representatividade do conselho.

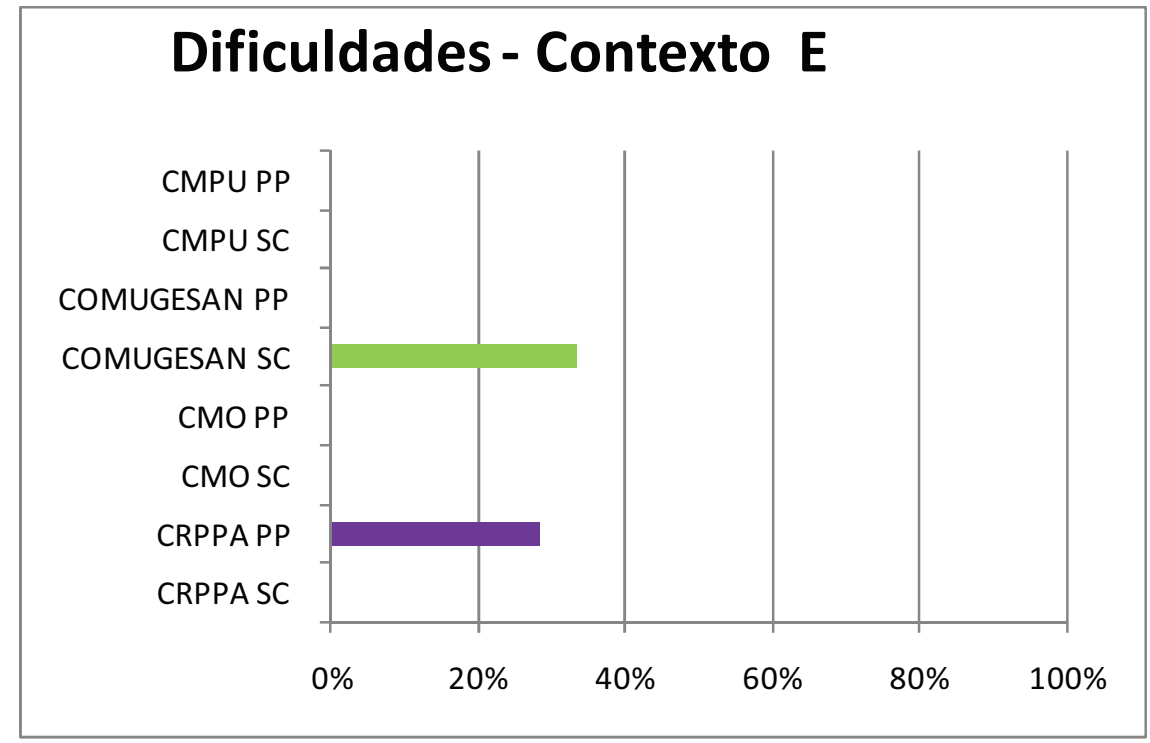

Gráfico 31: Dificuldades - Contexto E Fonte: Vendramini, 2010.

Dificuldades - Contexto F: neste contexto, ficaram reunidas as dificuldades diretamente ligadas à sociedade civil, tais como a disputa política entre grupos, às lutas por demandas individuais, à falta de 
organização da sociedade e aos setores da sociedade que são refratários aos processos participativos.

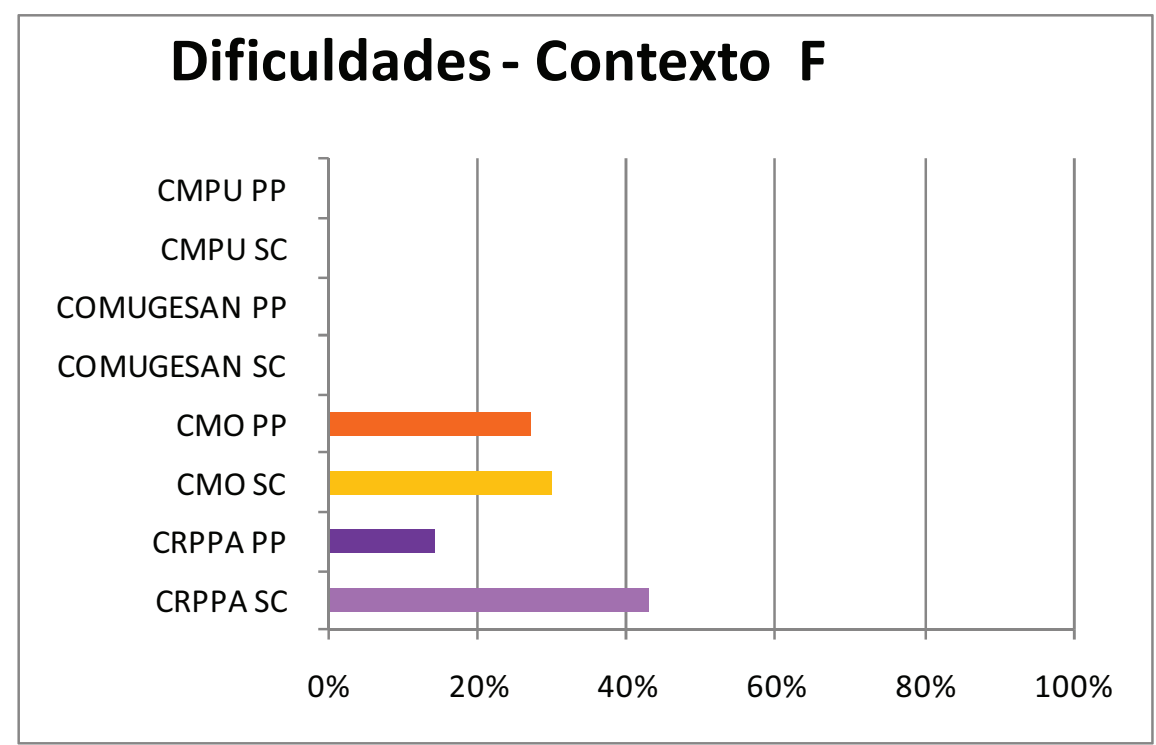

Gráfico 32: Dificuldades - Contexto F Fonte: Vendramini, 2010.

Dificuldades - Contexto G: as dificuldades agrupadas neste estão diretamente ligadas ao poder público, tais como: falta de diálogo com a sociedade civil, resistência inicial da prefeitura aos processos participativos, a falta entendimento dos conselhos como pertencentes à política de governo por parte de alguns conselheiros, burocracia, falta de vontade política, alteração pelo poder público do que foi decidido em conselho e transparência. 


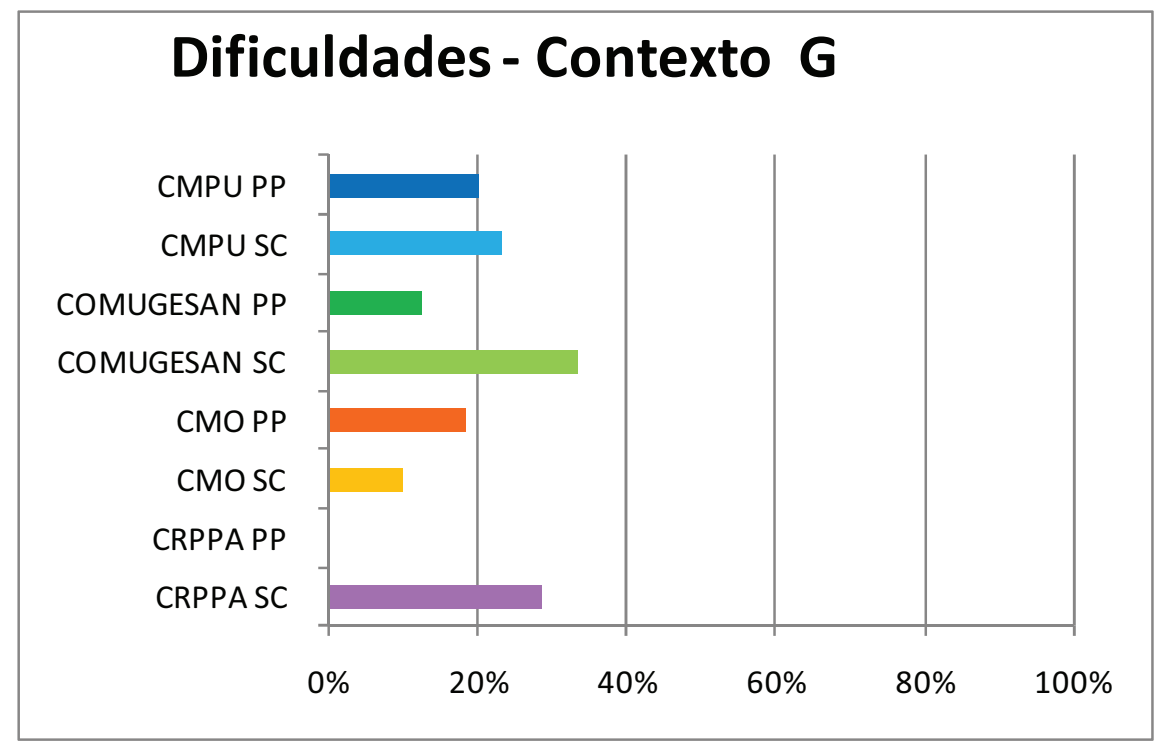

Gráfico 33: Dificuldades - Contexto G Fonte: Vendramini, 2010.

Dificuldades - Contexto $\mathrm{H}$ : os limites para a ação dos conselhos mostraram ser dificuldades para alguns conselheiros e ficaram agrupados neste contexto, tais como: as restrições técnicas para atender algumas demandas, limites orçamentários, limites da ação municipal e os processos de um ano político.

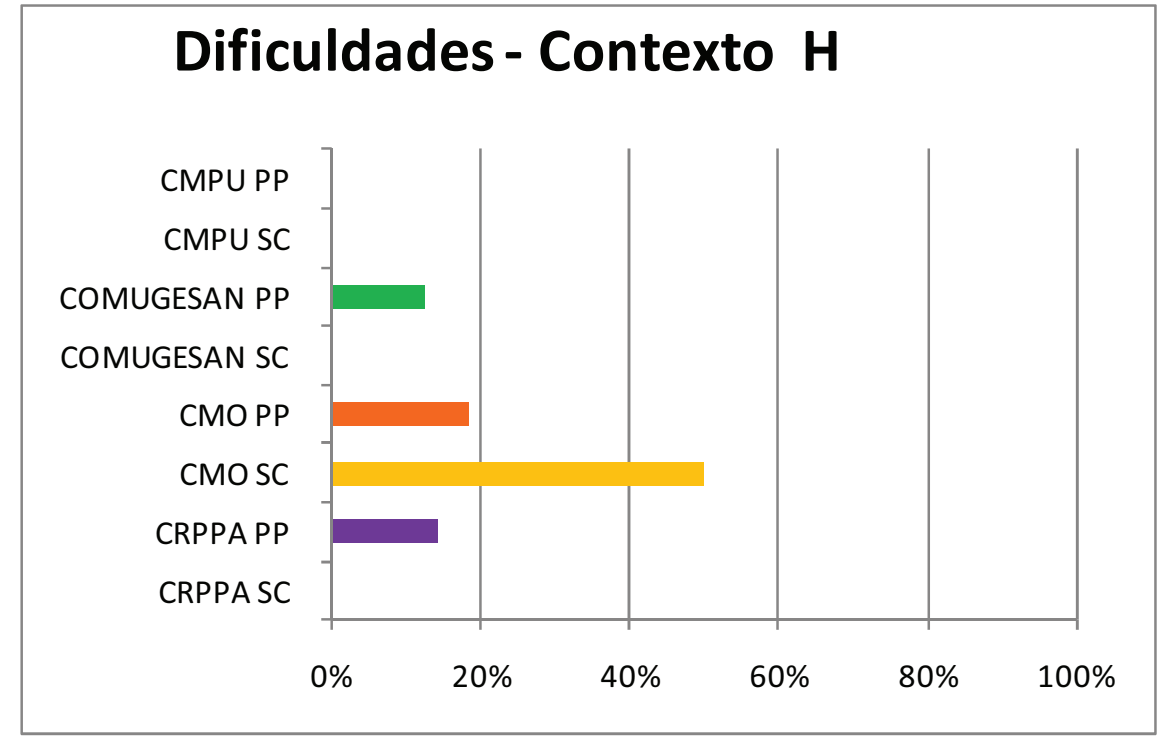

Gráfico 34: Dificuldades - Contexto H

Fonte: Vendramini, 2010. 


\section{Considerações}

Em relação às dificuldades não houve uma clara concentração de respostas. Três contextos obtiveram respostas em sete dos oito grupos de conselheiros (grupos compostos pelos quatro conselhos com duas representações em cada, poder público e sociedade civil). São eles: Contexto $B$, que trata de deficiências de capacitação para a ação no conselho, o Contexto C, que aborda as dificuldades para a participação nas reuniões, incluindo tempo, transporte, entre outros, e o Contexto G que trata das dificuldades de atuação por parte do poder público.

Os Contextos $\mathrm{F}$ e $\mathrm{H}$ são dificuldades apontadas principalmente pelos conselhos reivindicativos, que são: as dificuldades relacionadas com a atuação da sociedade civil, como disputas internas e falta de organização e os limites de atuação dos conselhos, como restrições orçamentárias, impossibilidades técnicas, entre outros.

O Contexto $A$, que diz respeito às dificuldades internas ao conselho, foi mais evidenciado pelo CMPU. O Contexto $D$, relacionado à mobilização para participação foi citado majoritariamente pelo $\mathrm{CMO}$, pois este é o que depende da mobilização do cidadão comum para seu pleno funcionamento. $O$ contexto $E$, que diz respeito às dificuldades de representatividade foi evidenciado pelo poder público do CRPPA e pela sociedade civil no COMUGESAN.

4.4.5 Questão 15 - Diferenças de Atuação entre os Conselheiros que são Funcionários e Gestores Públicos e os da Sociedade Civil

A questão número 15 da entrevista é: "Na sua opinião existe diferença de atuação entre os conselheiros que são funcionários público e os 
da sociedade civil? O objetivo desta questão é levantar as diferenças de atuação entre as duas representações no conselho.

CMPU • poder público

O CMPU teve 14 respostas válidas de conselheiros do poder público. Dos entrevistados, três conselheiros afirmam que seguem a orientação do governo para votação, o que representa $21 \%$ das respostas. Outros $5(36 \%)$ também deram a entender que existe sim, uma postura de apoio à decisão oficial, mas com ressalvas, como, por exemplo, este conselheiro da prefeitura, que mostra que existe maior ou menor liberdade de ação dependendo do tipo de funcionário: comissionado ou de carreira ${ }^{58}$.

"Existe. Existe diferença entre o conselheiro que é
comissionado, existe a diferença entre o conselheiro que
é de carreira e da sociedade civil. Isso é latente nas
reuniões. É muito claro. [...] O conselheiro do governo
comissionado, [...], sempre vai com um objetivo,
defender o interesse do governo, isso é claro, isso acima
de qualquer situação às vezes, né. No caso do conselheiro
funcionário de carreira, ele tem uma certa pressão, claro
que isso é sempre negado lá, de que a coisa não caminhe
por um lado, mas ele tem vontade, você percebe, de que
a coisa fluísse por outro, e aí, dependendo de como é
colocada a coisa técnica, até por esse funcionários de
carreira que fazem parte do conselho, a sociedade civil
ganha força ali prá reclamar, boicotar, esse tipo de coisa,
né."

Este conselheiro afirma que pode existir divergência entre a opinião do conselheiro do poder público e a orientação recebida, mas às vezes ela é muito mal recebida por parte do governo.

"[...] lá [no CMPU], nem sempre o governo é uníssono. Tanto que a gente já teve $\mathrm{N}$ casos de destituições de

${ }^{58}$ Assis (2009) não quantifica sua análise, mas apresenta resultados semelhantes. 
funcionários públicos como representantes no conselho. A gente já teve pessoas extremamente atuantes, mas insatisfeitas com essa postura da coordenação, chegaram a manifestar em plenária que estavam contrárias a essa postura do governo e foram destituídas da sua representação e de seus cargos, muitas vezes, da própria prefeitura [em seguida ele cita um exemplo]."

Este afirma que no CMPU é mais raro que se peça concordância com uma proposta oficial do que no outro conselho que ele participa, mas que isto acontece.

"[...] porque existe alguma matéria que é interesse do governo, então existe, claro, uma solicitação pra você estar encaminhando aquela coisa e se posicionando de determinada maneira. É muito esporádico, mas pode existir essa possibilidade."

Nesta resposta fica claro que o poder público aprova o que ele próprio decide no conselho.

"A gente é que toma as decisões finais. A gente que assina o papel que o conselho deliberou como coisa importante."

Por fim, este conselheiro afirma que os membros do poder público são indicados de forma a "não por a perder o trabalho".

"[...] e na hora, inclusive de fazer a escolha dos representantes de governo, a gente também tria isso. Não vou colocar lá uma pessoa que seja um técnico cego, porque senão ele pode por a perder o trabalho."

Ao considerarmos estas cinco respostas como indicadores de que o poder público orienta a atuação de seus representantes no conselho, sobe para $57 \%$ dos conselheiros do poder público que afirmam existir uma atuação do poder público em bloco. 
Duas pessoas (14\%) dizem que não existe diferença de atuação, afinal, apesar de os interesses serem outros, o comportamento dos conselheiros é o mesmo.

Outros quatro conselheiros (29\%) afirmaram que existem mais diferenças de formação e interesses entre os componentes da sociedade civil do que entre os representantes do poder público.

Para dois (14\%) representantes do governo, os membros da sociedade civil são mais críticos e envolvidos, enquanto que para outro (7\%) conselheiro acontece justamente o oposto: os conselheiros do poder público, por lidarem com questões relacionadas ao município no seu dia a dia, são mais envolvidos com as questões do governo que os da sociedade civil.

Por fim, um (7\%) membro do poder público sinalizou que o número de conselheiros da sociedade civil varia mais que os do poder público nas reuniões.

\section{CMPU $\cdot$ sociedade civil}

Dos 14 conselheiros da sociedade civil entrevistados, seis (43\%) afirmaram não existir diferença de atuação entre conselheiros do poder público e da sociedade civil. Dois destes conselheiros, apesar de dizer que não existem tais distinções, apontaram pequenas diferenças: um (7\%) disse que o governo tem um papel de promover a contextualização dos demais conselheiros sobre os assuntos tratados; o outro disse que a única diferença é que os conselheiros do poder público são remunerados e os da sociedade civil, não. Sabe-se, porém, que não existe remuneração para participação no conselho e que as reuniões são realizadas fora do horário de expediente destes conselheiros.

Em três respostas (21\%) pôde-se notar indícios de que o poder público tem uma atuação amarrada aos interesses do governo, o que 
faria com que houvesse uma atuação em bloco. Este considera normal que o superior oriente a atuação no conselho de seus subordinados

"Existe. [...] Tem alguns funcionários que está na gestão do conselho, que esse, evidentemente tem o seu interesse, e a cada momento tem um interesse. $E$ os que não são gestores do conselho, esses têm um pensamento livre, né. Mas, conforme o grau maior ou menor do vínculo que cada um tenha com a estrutura do conselho, e essas ramificações evidente são teias que se tecem lá dentro do próprio organograma da prefeitura, é claro que existe um influência, né. Então o secretário de desenvolvimento urbano e habitação exerce uma influência sobre a diretora de obras e assim por diante, isso é meio obvio, né? Isso com certeza deve acontecer. Então ele fala: - Eu preciso que você faça... que aconteça isso lá no conselho, vocês precisam analisar esse assunto. E com certeza isso é natural, né?".

Este outro conselheiro considera normal que exista uma relação entre a atuação no conselho e a permanência no emprego entre os funcionários do poder público.

"Existe sim [...] Quem está na bancada civil tem uma preocupação mais direta [...] com aquela área onde mora [...] e quem está na bancada do governo se preocupa mais com a gestão, mas, tem uns que são empregados, claro, tem essa questão do emprego, acho, também. Mas no fundo acho que eles acabam se preocupando mais com a gestão."

Este conselheiro afirma que a sociedade civil é desunida e os membros do poder público votam de uma forma pré-determinada.

"Existe sim. Nós sentimos que a sociedade civil, quando há um desemboque de idéias em torno de uma discussão, nós não temos uma unanimidade na sociedade civil. [...] O governo tem uma unanimidade muito maior. Quer dizer, "quando temos que ter uma maioria, a sociedade civil tem divergência de opiniões, o que é natural. E é 
raro, não que nós não temos, mas é raro que isso aconteça do lado do governo. [...] Normalmente o governo, quando determina e vota de uma forma, todo mundo vota de uma forma. [...] mas, na sociedade civil há mais divergências do que no governo, e isso, de alguma forma, acaba acontecendo que o governo consiga aprovar mais as suas idéias que a sociedade civil."

Outras três (21\%) falam claramente que os funcionários do poder público têm mais facilidade de atuação por ter a formação e as informações necessárias para tomar decisões com mais disponibilidade. Isso pode ser percebido no seguinte trecho:

"Eles têm muito mais facilidade de entender o processo. A sociedade deveria ter mais formas de entender mais e poder se manifestar mais ainda."

Para um conselheiro,

"O do poder público tem interesse no trabalho dele o a sociedade civil tem interesse na melhoria da cidade."

CMPU

Entre as respostas dos conselheiros do poder público fica mais evidente que os representantes do governo seguem a posição oficial do que entre os membros da sociedade civil. Os da sociedade civil também percebem, embora menos, as diferenças de atuação entre os dois setores, mas evidenciam a necessidade de informação mais rápida e ampla para poder melhorar sua atuação no conselho.

COMUGESAN · poder público.

Dos nove conselheiros do COMUGESAN do governo que responderam a esta questão, apenas uma pessoa afirma que não existe diferença de atuação entre as representações (11\%). 
Quatro membros (44\%) afirmam que o poder público é mais uníssono. Alguns complementaram suas respostas com argumentos como: organização fora do conselho, mais tempo dedicado às questões relacionadas ao assunto ou têm mais conhecimento técnico. Um entrevistado, falando justamente sobre a união dos representantes do poder público, afirmou que:

"Talvez não exista da sociedade civil esta cumplicidade. Como o conselho se renova a cada dois anos, no momento que eles estão fazendo o fechamento como grupo [o grupo se desfaz] [...]."

E continuou

"[...] tanto que já teve uma pessoa que votou contra o poder público, mas é difícil isso acontecer."

Um dos membros do governo afirmou que os representantes do poder público são mais presentes, e que os membros da sociedade civil faltam mais.

COMUGESAN $\cdot$ sociedade civil

Dos oito respondentes, dois (25\%) afirmam não haver diferença de conduta, sendo que um destes dois afirma:

"Não, às vezes na reunião a gente nem sabe quem é quem."

Este não saber quem é quem, pode ser um indício de que a ação de todos os conselheiros é realmente semelhante no plenária, mas, também pode indicar que, justamente por "não saber quem é quem", este conselheiro não percebe se existe diferença de atuação ou uma opinião préestabelecida.

Apenas dois (25\%) membros do conselho afirmaram que os conselheiros do poder público defendem os interesses do governo. E outros 
dois afirmam que os conselheiros do poder público estão muito mais interessados no conselho que os da sociedade civil.

A resposta que mais se destaca entre os conselheiros da sociedade civil diz respeito à diferença de nível de conhecimento sobre o assunto que está sendo tratado, tanto quanto à formação dos participantes, quanto á informação específica sobre o assunto. Metade (50\%) destes, percebe a diferença no nível de informação para tomada de decisão.

Um (13\%) conselheiro da sociedade civil argumentou que os funcionários, por serem pagos, estão mais envolvidos. Porém, vale novamente ressaltar que estes funcionários não são pagos diretamente para participar do conselho e sim pelo seu trabalho na prefeitura.

\section{COMUGESAN}

Analisando o material sobre a forma de atuação dos conselheiros do poder público e da sociedade alguns aspectos ficam evidentes. Em primeiro lugar, os conselheiros do poder público percebem com mais clareza que existe uma união sobre a decisão do governo, e explicitam que existem reuniões prévias para acertar a conduta antes da reunião do conselho. Corroborando este fato, nota-se que mais pessoas da sociedade civil pensam não haver diferença de atuação entre os dois tipos de conselheiros ( $25 \%$ da sociedade civil e $11 \%$ do poder público).

Pode-se resumir a opinião dos conselheiros do COMUGESAN quanto à forma de participação no conselho da seguinte forma: O poder público (44\%) reconhece que há uma posição de grupo para a deliberação e a sociedade civil $(50 \%)$ se sente menos informada para poder tomar a decisão. 
CMO - poder público

Foram entrevistados 13 conselheiros do CMO pertencentes ao poder público. Apenas dois (15\%) alegaram que não há diferença de atuação, sendo que um deles argumentou que no CMO evita-se a votação através da busca do consenso. Mesmo com essa postura de se evitar que haja votação, 38\% dos entrevistados afirmam que poder público discute antes das reuniões que postura tomar, agindo em bloco. Isto pode ser percebido no seguinte comentário:

"O governo já tem o cenário desenhado quando vai para a reunião. Ele sabe até aonde ele pode ceder ou não. $A$ sociedade civil não sabe."

Entretanto, no $\mathrm{CMO}$, oito (63\%) dos conselheiros do poder público percebem a diferença de atuação de outra maneira. Para eles, os membros do conselho do governo trazem o caráter e os limites técnicos para as reuniões, enquanto os conselheiros da sociedade civil trazem 0 conhecimento local e as demandas da população. Esta é a principal diferença apontada por eles.

Somente quatro (31\%) conselheiros dizem perceber que existe uma atuação em bloco por parte dos conselheiros do poder público, e afirmam que existe uma política de se buscar o consenso para evitar o confronto através da votação.

\section{CMO $\cdot$ sociedade civil}

Das 14 respostas válidas dadas por conselheiros da sociedade civil do CMO, duas (14\%) pessoas afirmaram não haver diferença de atuação entre os conselheiros da sociedade civil e do poder público e outra $(7 \%)$ disse que não se pode generalizar, o que também será considerado com um não. Portanto, $21 \%$ dos conselheiros da sociedade civil afirmam que não existem diferenças, ou melhor, que não existem diferenças 
generalizáveis de atuação entre os conselheiros do poder público e da sociedade civil no CMO.

Do total, cinco (36\%) entrevistados reiteram a posição dos conselheiros do poder público de que estes últimos têm uma participação mais técnica, o que inclui apresentar os limites na possibilidade de realização das demandas apresentadas, enquanto os conselheiros da sociedade civil têm um caráter mais reivindicativo.

Apenas dois conselheiros (14\%) afirmam que os membros da sociedade civil participam menos das reuniões do conselho, e cinco (36\%), em suas respostas, indicam a existência de dois blocos distintos nas reuniões: a sociedade civil e o poder público. Neste ponto, aparece um dado importante. Um conselheiro que também participa de outro conselho, respondendo esta mesma questão em sua entrevista para esta pesquisa, afirmou:

"Se você tiver falando da OP eu falo a mesma coisa, da OP eles chegaram lá na última, vai, nós tivemos eleição aqui no bairro dos seus problemas no bairro, passou três. Chegou lá eles queriam que mandasse a proposta, eu mandei a proposta das três causas. Eles me mandaram a contraproposta, dois pontos. E se eu não aceitasse esses dois pontos eu perdia tudo. Você imagina que eles fizeram um, eu não participei né porque eu entrei agora então eu não participei do documento das normas da leis da OP, aí é assim, se for pra eleição em último caso se for pra eleição, nós temos 19 região, Santo André tem 19 região, das 19 só 12 deu quorum. Então só 12 conselheiros têm direito a voto. Aí o que acontece? Você tem de ter 12 votos a seu favor lá na eleição né e mais 4 do governo votando a seu favor. Ou o governo tem os 12 e 4 dos conselheiros votar no governo, se der empate não faz nada. Aí como você me diz isso, existe? Aí como é que eles fazem? Ou você aceita ou aceita, entendeu. Já pensou se eu bato o pé? - não, eu quero os três que foi eleito. Aí eu vou pra votação e perco, aí não é feito, a 
população vai cair em cima de quem? Do conselheiro. Porque aí eles vão reclamar pra prefeitura e - não, o seu conselheiro que não aceitou. Aí, esse é o problema, lá nós tivemos vários problemas, foi do começo ao final, foi 2 meses, 3 vezes por semana e sabe muita discussão, mas no fim deu nisso. Foi feito o que? O que eles queriam. Porque nós não tínhamos como lutar entendeu. Se nós fôssemos pra... né, nós perdia. Eu não sei como que pode isso e depois fala que dá tapa a cara. Isso eu vejo, esse conselho tanto conselheiro do bairro como da OP que eles utilizam os conselheiros como laranja."

$\mathrm{CMO}$

No CMO, as visões entre os componentes do poder público e da sociedade civil parecem coincidir mais, tanto no que diz respeito a inexistência de diferença de atuação (3 na sociedade civil e 2 no poder público), quanto na formação de bloco por parte do poder público (38\% no poder público e $36 \%$ na sociedade civil).

Os componentes do governo explicitaram mais as diferenças de posições no conselho, isto é, quanto ao que cada setor representa: os membros da sociedade civil como conhecedores das necessidades locais, explicitadores de demandas e fiscalizadores do cumprimento dessas demandas por parte do governo; os membros do poder público aparecem como os conhecedores da máquina do governo e das possibilidades e limites técnicos de cada uma das demandas apresentadas. No poder público, 63\% dos conselheiros explicitaram esta diferença de atuação, enquanto apenas $36 \%$ dos membros da sociedade civil o fizeram.

CRPPA $\cdot$ poder público

Entre os conselheiros do CRPPA, um entrevistado não respondeu à questão 15 , portanto, serão trabalhadas apenas sete respostas. Dentre elas, dois conselheiros do governo (29\%) afirmaram que não existe 
diferença de atuação entre os membros do poder público e os da sociedade civil.

Quanto à união entre os blocos - sociedade civil e poder público - quatro conselheiros (57\%) afirmam que o poder público se prepara antes das reuniões e adotam uma postura uniforme. Agravando esse quadro de união do governo, três conselheiros (43\%) afirmam que a sociedade civil é muito desunida e desarticulada, o que somado à dificuldade de transporte para ir às reuniões, faz com que muitas reuniões nem aconteçam por falta de "quórum".

Estes aspectos podem ser percebidos nos discursos dos próprios conselheiros:

"Sim né, porque na verdade a gente fala como ... em unicidade no Conselho e a sociedade civil nem sempre eles concordam entre si né, cada um representa um segmento diferente, um bairro diferente, então eles vêm com propostas diferentes. Se a gente discorda de algum assunto no conselho, normalmente a gente discutiu esse assunto antes, várias vezes nós tivemos reuniões antes da reunião do conselho, né, reuniões internas pra fechar uma postura de governo. Então a gente normalmente a diferença de atuação é essa, mesmo que, por exemplo, eu não concordasse muito com algo que vai ser levado internamente resolveu-se que aquele era a melhor forma de encaminhar um assunto, então tudo bem, na hora de votar eu voto com o governo."

$\mathrm{Ou}$

"Sim [...] é eu que tenho que ir, eu vou mesmo que é longe mesmo que não sei o que mesmo que não sei o que lá. E eu vejo a atuação, é isso que eu te falo, quando eles estão juntos eu acho que a discussão é boa eles têm propriedade de discutir, pode ser até que não é uma coisa que eu concorde, mas tem fundamento naquilo que ele está falando, mas a... eu acho que nós do governo vamos, não estou dizendo que somos bons, a gente vai 
se compromete a ir e vai, só que a gente chega lá e não tem a reunião."

CRPPA $\cdot$ sociedade civil

Entre os conselheiros da sociedade civil também houve um que não respondeu esta questão, ficando então um total de sete respostas válidas. Quando analisadas estas respostas, nota-se que apenas um membro afirmou não haver diferença entre a atuação dos representantes do poder público e da sociedade civil.

Três pessoas (43\%) indicaram que o poder público atua de forma unida e três ( $43 \%$ novamente) que a sociedade civil é muito desunida. Como pode exemplificar o discurso a seguir:

"Olha o poder público é aquilo. Eles fazem o que [nome da pessoa] manda, eles são obrigados. [...] Então, esse é o problema. O problema é esse é que os conselheiros desacreditam né, porque eles reivindica uma coisa, duas, três e não é feita nenhuma, desiste. E é o que acontece aqui, infelizmente muitos dos conselheiros não vão. Tem os puxa saco deles que aonde tá eles tão, mas a maioria não vai por causa disso daí, entendeu."

Um participante do conselho contestou a falta de informações para que eles possam participar das reuniões com propriedade $^{59}$.

Nesta questão, houve, porém, uma resposta diferente. Um conselheiro questiona as decisões tomadas em reuniões com pouca participação da sociedade civil, onde o poder público traz um assunto e o conselho incompleto delibera sobre ele. Veja a fala deste conselheiro:

"É porque é uma coisa que tinha que tinha que ter uma ética uma... deixar se eles decidirem, mas não foi a administração que decidiu, porque na verdade foi porque

${ }^{59}$ Cezare (2009) não quantifica sua análise, mas apresenta resultados. 
a última pessoa que assina um decreto uma coisa é a administração, não jogar a culpa pra cima de um Conselho que nem viu ou não participou por não estar lá. Então foi complicado, foi um caso, os conselheiros que estavam... agora você vê o Conselho aqui parou, do meio do ano pra cá o Conselho não tá ativo, não sei se vocês sabem, e foi por esse motivo de tomarem algumas decisões lá na administração e dizerem pra pessoa que foi decidido no Conselho. Aí os conselheiros ficaram amedrontados porque tem em ata, tem discussão, (...) e vinham perguntar o que aconteceu tirar satisfação, outros bravos outros nem falam mais comigo, então por conta de algumas atitudes que foi tomada do governo né que é uma administração que toma as atitudes, não é o Conselho é discutido no Conselho, mas se não tem paridade se não está igual então quem toma as atitudes tinha que assinar embaixo e dizer - olha foi a administração que tá fazendo. E não jogar pra cima do Conselho - foi o Conselho que decidiu. E aí? Nós ficamos numa situação do Conselho se desfazer todinho né. Foi por conta disso que o Conselho parou um pouco aqui, você pode ver que teve pessoas que foram saíram do Conselho por ter faltado tantas vezes, porque acho que por três faltas você já era cassado, então teve pessoas, todo Conselho foi cassado por não irem e foi por conta disso daí. Então não sei, teve coisas que foram tomadas."

CRPPA

No Conselho de Representantes de Paranapiacaba e Parque Andreense, dois conselheiros do poder público e um da sociedade civil não notam diferença de atuação entre os dois segmentos: $50 \%$ dos conselheiros (quatro do poder público e três da sociedade civil) mencionam a atuação em bloco por parte dos funcionários do governo e, 43\% (três conselheiros de cada setor) apontam que os membros da sociedade civil são desunidos e freqüentam menos as reuniões do conselho ${ }^{60}$.

${ }^{60}$ Análise corroborada pelo trabalho de Cezare (2009). 
Considerações

De todas as respostas dadas à questão: "Na sua opinião existe diferença de atuação entre os conselheiros que são funcionários público e os da sociedade civil?" foram identificados quatro contextos principais. Estas respostas estão quantificadas na tabela 6 e nos gráficos 35 a 38 que seguem:

Tabela 6: diferenças de atuação no conselho • contextos

\begin{tabular}{|c|c|c|c|c|c|}
\hline & $\begin{array}{l}\text { respostas } \\
\text { válidas }\end{array}$ & $\begin{array}{c}\text { Atuação - } \\
\text { Contexto A }\end{array}$ & $\begin{array}{l}\text { Atuação - } \\
\text { Contexto B }\end{array}$ & $\begin{array}{l}\text { Atuação - } \\
\text { Contexto C }\end{array}$ & $\begin{array}{l}\text { Atuação - } \\
\text { Contexto D }\end{array}$ \\
\hline CMPU PP & 15 & 1 & 8 & 1 & 1 \\
\hline CMPU SC & 14 & 6 & 3 & 1 & 3 \\
\hline COMUGESAN PP & 9 & 1 & 4 & 1 & 1 \\
\hline COMUGESAN SC & 8 & 2 & 2 & 0 & 5 \\
\hline CMO PP & 13 & 2 & 5 & 0 & 0 \\
\hline CMO SC & 14 & 3 & 4 & 2 & 0 \\
\hline CRPPA PP & 7 & 2 & 4 & 3 & 0 \\
\hline CRPPA SC & 7 & 1 & 3 & 3 & 1 \\
\hline
\end{tabular}

Fonte: Vendramini, 2010.

Atuação - Contexto A: o entrevistado não vê diferença de atuação entre os conselheiros da sociedade civil e os do poder público, ou, pelo menos, não vê diferença significativa para poder caracterizar cada setor. 


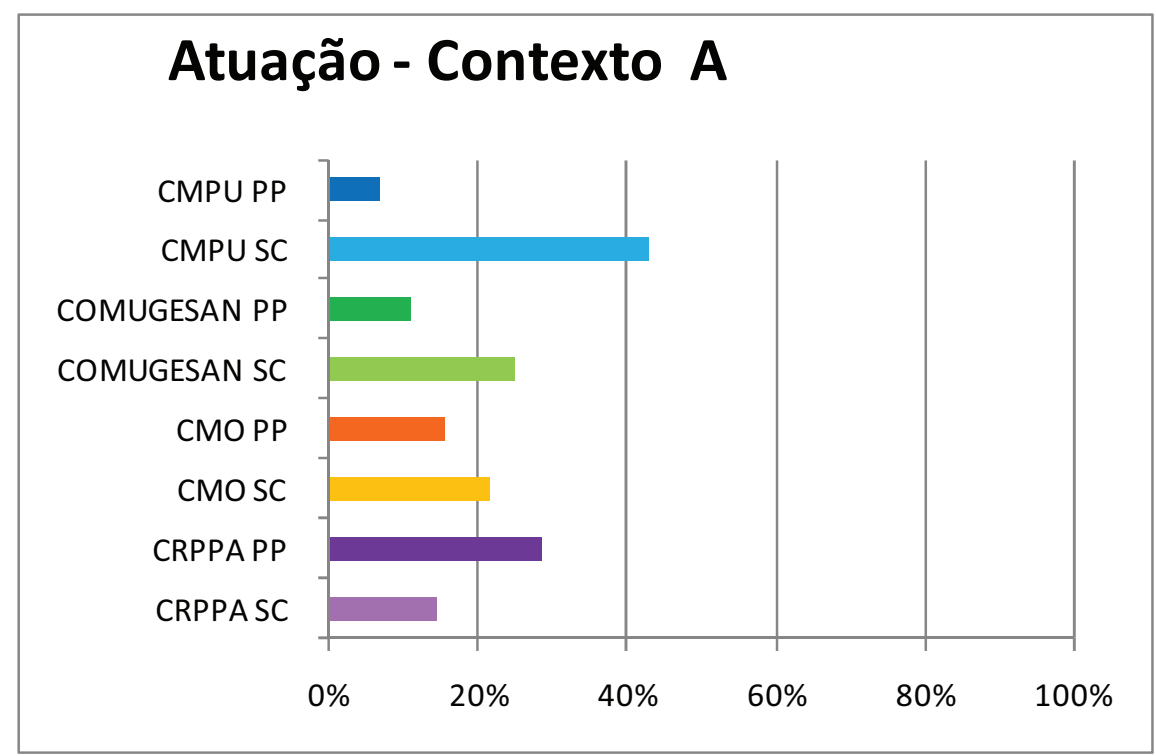

Gráfico 35: Atuação - Contexto A Fonte: Vendramini, 2010.

Atuação - Contexto B: o poder público faz reuniões internas e define que posição que deve defender na reunião do conselho; o funcionário público sabe como deve votar ou o que deve defender, ou por estar ciente da linha de conduta do governo, ou por receber orientação superior. Isto caracteriza uma ação em bloco por parte dos representantes do poder público.

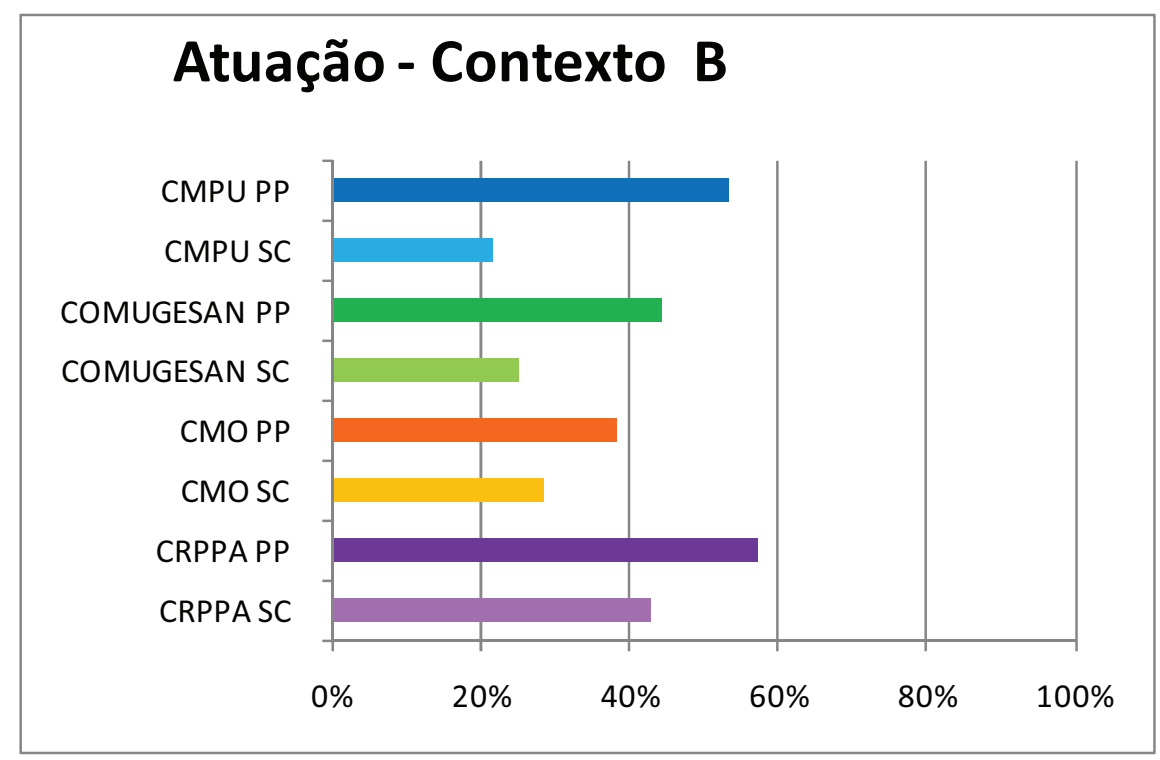

Gráfico 36: Atuação - Contexto B

Fonte: Vendramini, 2010. 
Atuação - Contexto C: a sociedade civil é menos organizada: por ter pouco tempo de convivência, uma vez que o mandato é de dois anos. Por ter interesses distintos entre si, já que alguns conselhos têm representantes de empresários e ONGs; por ser de locais muito diferentes, como Paranapiacaba e Parque Andreense; ou por ter que conciliar suas atividades de conselheiro com suas atividades profissionais - coisa que os funcionários do governo também têm que fazer, mas, para estes, ambas as atividades têm um grau elevado de continuidade.

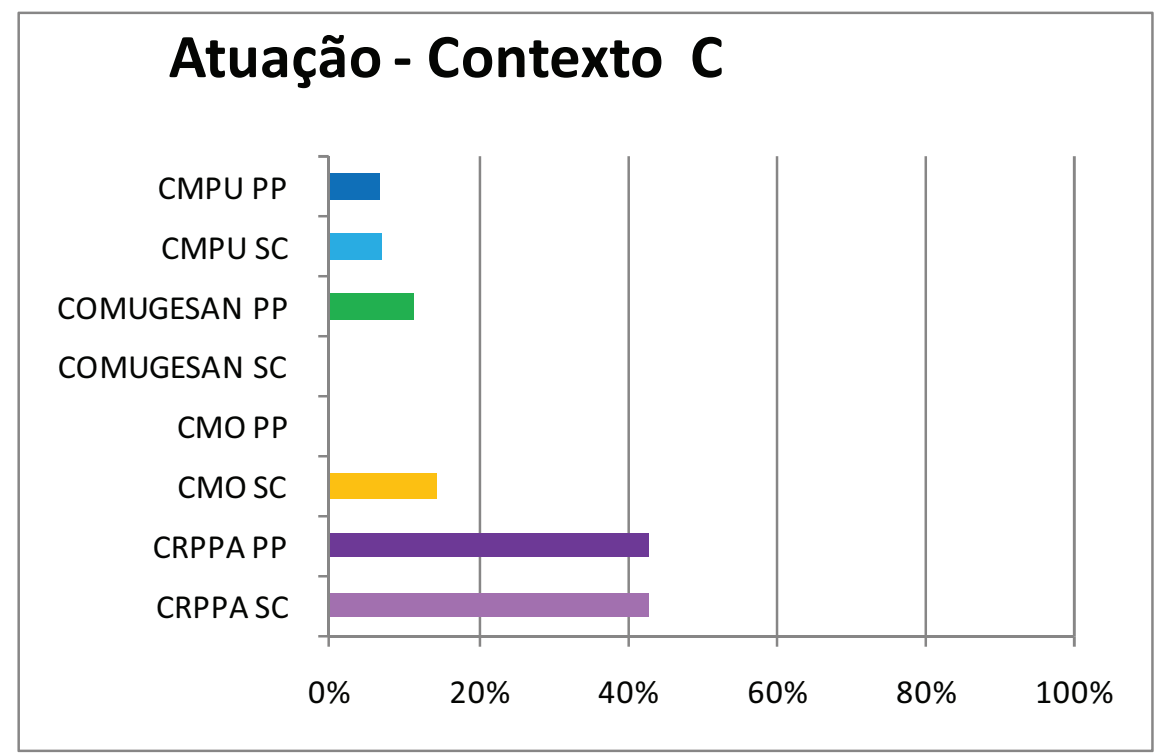

Gráfico 37: Atuação - Contexto C

Fonte: Vendramini, 2010.

Atuação - Contexto D: a sociedade civil tem menos acesso a informações sobre os assuntos a serem tratados nas reuniões, em contraponto aos funcionários que trabalham com elas no seu dia a dia. Isto traz dependência dos conselheiros da sociedade civil em relação com os do poder público, traz desvantagem na hora de argumentar, traz incapacidade de tomar uma posição consciente. 


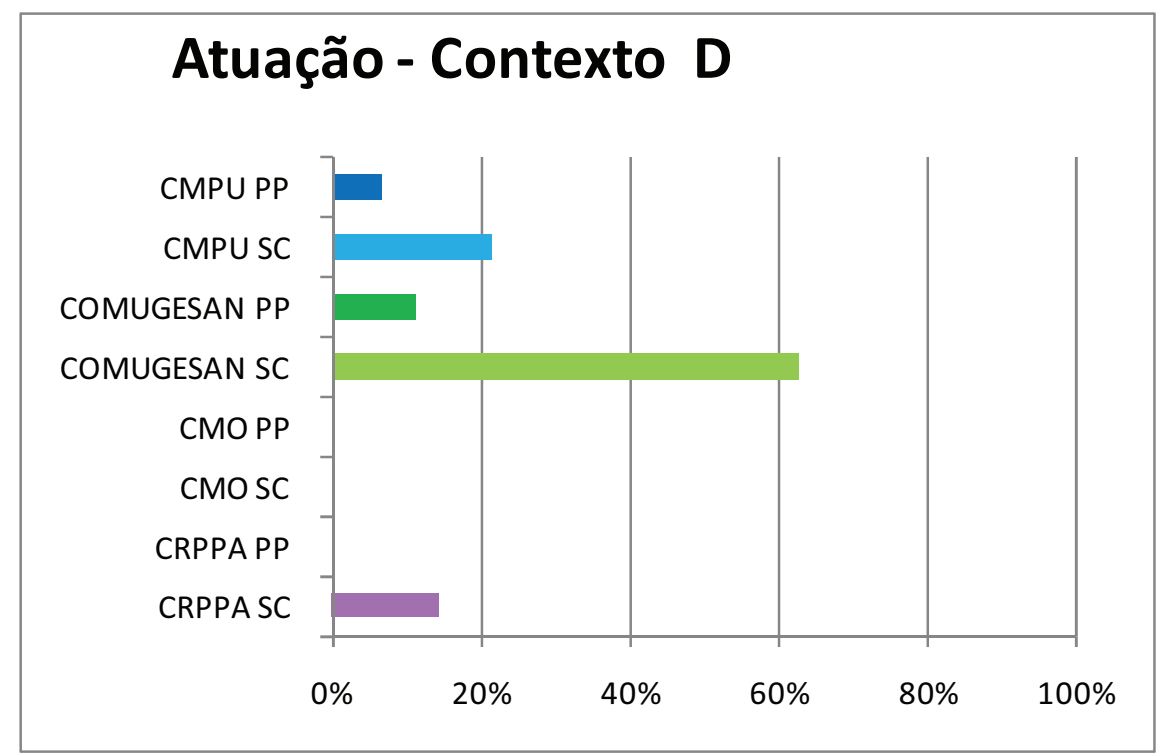

Gráfico 38: Atuação - Contexto D

Fonte: Vendramini, 2010.

Nota-se que o contexto $B$ foi o mais descrito nas respostas de todos os conselhos. Existe realmente uma tendência do poder público votar em bloco, e isto foi expresso pelos próprios conselheiros do governo, mais do que pelos conselheiros da sociedade civil. São os conselheiros da sociedade civil que menos percebem diferenças de atuação entre os dois setores (contexto $A$ ), o que corrobora os números do contexto $B$.

Quanto ao contexto C, que indica uma desorganização da sociedade civil com relação à participação no conselho, fica evidente que este é um problema que se concentra no Conselho de Representantes de Paranapiacaba e Parque Andreense. Segundo um dos entrevistados, o conselho tem conseguido se reunir muito pouco devido às desavenças entre a sociedade civil e o poder público nas reuniões.

No contexto D, que expressa a necessidade de os conselheiros da sociedade civil terem acesso a mais informações, pode-se notar que o CRPPA, que passa por um momento de crise, aponta este problema, e que, os conselheiros da sociedade civil do CMPU e do 
COMUGESAN, conselhos com caráter mais técnico, também sentem falta de informações para deliberar com mais tranqüilidade.

4.4.6 Questão 11 a Questão 14 - Questões Relacionadas à Informação para a Participação nos Conselhos

- Questão 11. Você acha que os conselheiros são suficientemente informados para participar do conselho?

- Questão 12. Como você se mantém informado para participar do conselho?

- Questão 13. Que tipo de informação você acha que os conselheiros deveriam receber para melhorar a qualidade de sua participação no conselho?

- Questão 14. De que forma estas informações poderiam chegar até os conselheiros?

Estas quatro questões foram formuladas para levantar se os conselheiros têm informações suficientes para a tomada de decisão. Nas respostas dos conselheiros, os assuntos destas quatro questões às vezes se misturavam. Buscou-se então, na categorização destas respostas, respeitar os conteúdos apresentados pelos entrevistados, relevando o fato do conteúdo ter sido apresentado em outra questão deste grupo de quatro perguntas. Esta análise resultou em 14 contextos. Por entender que estes contextos já oferecem detalhamento suficiente, optou-se por apresentar a análise utilizando-se diretamente os agrupamentos em contextos, sem antes explicitar as categorias encontradas como foi feito nas questões apresentadas anteriormente. 
4.4.7 Questão 11 - Você acha que os Conselheiros são Suficientemente Informados para Participar do Conselho?

CMPU · poder público

Dentre as 15 respostas válidas para estas questões dadas pelos representantes do poder público no CMPU, 11 (73\%) afirmam que sim, os conselheiros são suficientemente informados para participar do conselho. Um dele diz que a capacitação interna é responsável pelo nível adequado de informação. Dois (13\%) conselheiros, ao contrário, pensam que as pessoas não estão suficientemente informadas para atuar no colegiado, e seis (40\%) afirmam que existe informação, mas ela é deficiente.

\footnotetext{
"Informados são, mas acho que falta um pouco de qualificação técnica para eles. Não que isso seja um prérequisito para participar do conselho, mas acho que o conselho é o lugar para se capacitar".
}

CMPU $\cdot$ sociedade civil

Entre os 14 conselheiros da sociedade civil no CMPU que deram respostas válidas, seis (43\%) afirmam que os conselheiros estão bem informados, mas nenhum atribuiu este nível adequado à capacitação. Quatro (29\%) dizem que as pessoas não estão suficientemente informadas e sete (50\%) que a informação que eles têm não é suficiente.

\footnotetext{
"Não, acho que não. Eles têm uma super boa vontade, eu acho isso muito legal".

"Sim, informados são. Porque a gente, desde a formação do conselho pego várias pessoas para formar o conselheiro, desde a formação do conselheiro até a formalidade mesmo. E sem tem dúvidas sempre tem pessoas dispostas a esclarecer".
} 
CMPU

Pode-se notar que, no CMPU os membros do poder público confiam mais no nível de informação para a atuação no conselho que os da sociedade civil. Apesar do CMPU ter um processo interno de capacitação, apenas um conselheiro do governo afirmou que ele contribui para o nível de informação de seus membros.

\section{COMUGESAN · poder público}

Dos dez conselheiros do governo no COMUGESAN que deram respostas válidas a estas questões, quatro (40\%) disseram acreditar que os conselheiros têm informação adequada para atuar no conselho e um (10\%) conselheiro afirma que isto se deve à capacitação interna. Por outro lado, três $(30 \%)$ dos membros dizem que as pessoas não têm informação suficiente para participar do conselho e três (30\%) que a informação que os conselheiros possuem é deficiente.

"Acho que sempre precisa. Porque acho que você tem um processo de formação inicial, mas acho que esse processo é permanente $[. .$.$] a grande dificuldade nossa é o tal do$ tempo, né. Como você equaciona o tempo?".

\section{COMUGESAN $\cdot$ sociedade civil}

Os conselheiros têm sim informações suficientes para atuar no colegiado para sete (70\%) dos dez membros do COMUGESAN que deram respostas válidas para esta questão. Um (10\%) atribui este nível adequado de conhecimento à capacitação dada no próprio conselho. Corroborando com esta maioria de aprovação, apenas um (10\%) conselheiro afirmou que os participantes não têm informações suficientes para participar no conselho e outro (10\%) disse que existe informação, mas que não é completa.

"O COMUGESAN não tem contribuído para a formação do conselheiro, tá, não contribui. O [outro conselho], por 
exemplo, ele fez um curso de capacitação para os conselheiros, apresentou. Então trabalhamos o que no conselho? Todas as leis. O papel do conselho eu sei qual é, no COMUGESAN, mas todas as outras coisas com que eu posso trabalhar ele tem uma capacitação. Foi até proposto no ano passado, uma capacitação dos conselheiros, foi proposto, foi discutido, no final do ano ela ia acontecer, em dezembro, aí, conselheiros "Horácios", acharam que não deveria acontecer em dezembro e pediram para fevereiro. Aí, não aconteceu até hoje. [...] falta capacitação".

\section{COMUGESAN}

Ao contrário do CMPU, no COMUGESAN os conselheiros da sociedade civil confiam mais no seu nível de informação e dos seus colegas para atuar no conselho. A capacitação interna foi novamente pouco responsabilizada pelo bom nível de conhecimento.

CMO - poder público

No CMO o nível de satisfação com o grau de informação para a participação no conselho é bastantes auto. Das 13 respostas válidas para estas questões entre os membros do poder público, nove (69\%) afirmam acreditar que sim, os conselheiros estão suficientemente informados para participar do conselho. Chama a atenção que seis (46\%) deles atribuem este fato à capacitação interna ao conselho. Apenas dois (15\%) membros do governo pensam que o nível de informação não é suficiente, e cinco (38\%) dizem que é intermediário.

"Eu acho que sim. [...] são lideranças, são eleitos pelos bairros. É lógico que é feito um trabalho de formação deles. Entendimento do que é orçamento, isso é importante e é pré-requisito para ser conselheiro, então, acho que tem que ter mesmo". 
"Então, esta é uma preocupação que foi evoluindo ao longo... é que o orçamento participativo de Santo André tem mais de 10 anos, né? Bem mais [...] Formamos, então quem é escolhido vai entender o que vai discutir, né, porque não vem só - Eu quero, eu quero, eu quero. Espera um pouquinho, funciona dessa forma, discute-se 0 regimento, ou seja, partilha-se todo o processo desde 0 início, então tem-se a preocupação de discutir e formar os conselheiros".

$\mathrm{CMO} \cdot$ sociedade civil

Os membros da sociedade civil apresentaram respostas similares aos do poder público a esta questão. Das 15 respostas válidas, nove $(60 \%)$ afirmam que sim, os conselheiros estão bem informados para participar do conselho. E cinco (33\%) que a capacitação interna ao colegiado cumpre este papel. Apenas três (20\%) membros dizem que não existe informação suficiente e quatro (27\%) acreditam que existe uma situação intermediária.

"Na primeira gestão não. Você só vai conhecer o conselho quando começa a participar dele".

"Nem sempre, né? Porque chega um momento que tem muitos fatores técnicos e administrativos. A própria administração faz a capacitação e clareia um pouco pro conselheiro participar da reunião".

$\mathrm{CMO}$

No CMO, a situação é bem homogênea entre poder público e sociedade civil organizada. Ambos, em sua maioria, acreditam que os conselheiros estão bem informados para a participação no conselho e que a capacitação interna é a responsável por este fato. Chama a atenção que as porcentagens das respostas foram similares para os quatro contextos definidos. 
CRPPA - poder público

Dentre as oito respostas válidas para estas questões dadas pelos representantes do governo no CRPPA, apenas dois (25\%) consideram que os conselheiros têm informações suficientes para participar do conselho e nenhum membro atribui este fato à capacitação interna, que parece não existir. Dois (25\%) outros membros acreditam que os conselheiros não têm informações suficientes para participar das reuniões e, por fim, outros dois (25\%) pensam que os conselheiros têm informações, mas não de forma completa.

\footnotetext{
"Nesse último não, mas nos conselhos anteriores nós fizemos formação política pra todos eles dentro do perfil do conselho daqui. Agora esse ano eles não aprovaram essa formação, mas mesmo assim a gente pega todos os conselheiros a gente leva eles em toda região porque os conselheiros eles são, a área aqui é muito grande e às vezes um conselheiro do Parque Andreense não conhece a realidade daqui ou de outro bairro, então a gente faz tipo uma caravana o dia todo com eles mostrando as características de cada bairro que tem conselheiro eleito".

"Você sabe que lá eu acho? As pessoas que estão lá são muito (...), pelo menos um que eu já conheço há muitos anos participa de movimentos é... ambiental, uma outra pessoa que é uma professora super, esta que inclusive é candidata ela é uma pessoa que sabe o que está falando é uma pessoa envolvida na comunidade lá, busca as coisas pra resolver. Então assim, eu acho que as pessoas lá, eu considero inclusive que lá se eles fossem um pouquinho mais organizados eles iam ser muito bons, do ponto de vista assim da discussão".
}

CRPPA $\cdot$ sociedade civil

Entre os oito membros da sociedade civil no CRPPA que deram respostas válidas a estas questões, apenas um (13\%) afirma que sim. Os conselheiros estão bem informados para participar do conselho, um 
(13\%) diz que existe informação, mas, não é suficiente e quatro (50\%) dizem que não existe informação suficiente para participar do colegiado.

"Aí que tá, não. Os conselheiros deviam ser... eu já vi, porque é assim, eleição fica as pessoas vão lá votar, mas pra votar as pessoas tinham que saber que as pessoas tinha que ter o mínimo de conhecimento, as pessoas tem uma personalidade forte, não são pessoas que negociam suas idéias à toa né, e saber que ele tá ali não pra representar a pessoa e sim a comunidade, porque se você foi eleito pela comunidade você não pode levar problema particular seu pra ser resolvido no Conselho e isso acontece muito. Deveria ter uma formação, tem os cursos né e tudo, mas o povo que precisa aprender não vai. $\mathrm{A}$ gente vai fica lá escutando coisa que tá cansado de saber e quem realmente precisava tá ouvindo não vai".

CRPPA

No CRPPA fica evidente que não se acredita que exista informação suficiente, principalmente por parte dos representantes da sociedade civil, e que a capacitação é totalmente inadequada! Poucos membros do conselho, independente da representação, acreditam que exista informações suficientes para a participação no CRPPA.

\section{Considerações}

De todas as respostas para: "Você acha que os conselheiros são suficientemente informados para participar do conselho?' foram identificados quatro contextos principais, que são apresentados na tabela 7 e nos gráficos 39 a 42 . 
Tabela 7: informações no conselho ' contextos

\begin{tabular}{|c|c|c|c|c|c|}
\hline & $\begin{array}{l}\text { respostas } \\
\text { válidas }\end{array}$ & $\begin{array}{c}\text { Informações } \\
\text { Contexto A }\end{array}$ & $\begin{array}{c}\text { Informações } \\
\text { Contexto B }\end{array}$ & $\begin{array}{c}\text { Informações } \\
\text { Contexto C }\end{array}$ & $\begin{array}{c}\text { Informações } \\
\text { Contexto D }\end{array}$ \\
\hline CMPU PP & 15 & 11 & 2 & 1 & 6 \\
\hline CMPU SC & 14 & 6 & 4 & 0 & 7 \\
\hline COMUGESAN PP & 10 & 4 & 3 & 1 & 3 \\
\hline COMUGESAN SC & 10 & 7 & 2 & 1 & 1 \\
\hline CMO PP & 13 & 9 & 2 & 6 & 5 \\
\hline CMO SC & 15 & 9 & 3 & 5 & 4 \\
\hline CRPPA PP & 8 & 2 & 2 & 0 & 2 \\
\hline CRPPA SC & 8 & 1 & 4 & 0 & 1 \\
\hline
\end{tabular}

Fonte: Vendramini, 2010.

Informações - Contexto A: Sim, os conselheiros são suficientemente informados para participar do conselho;

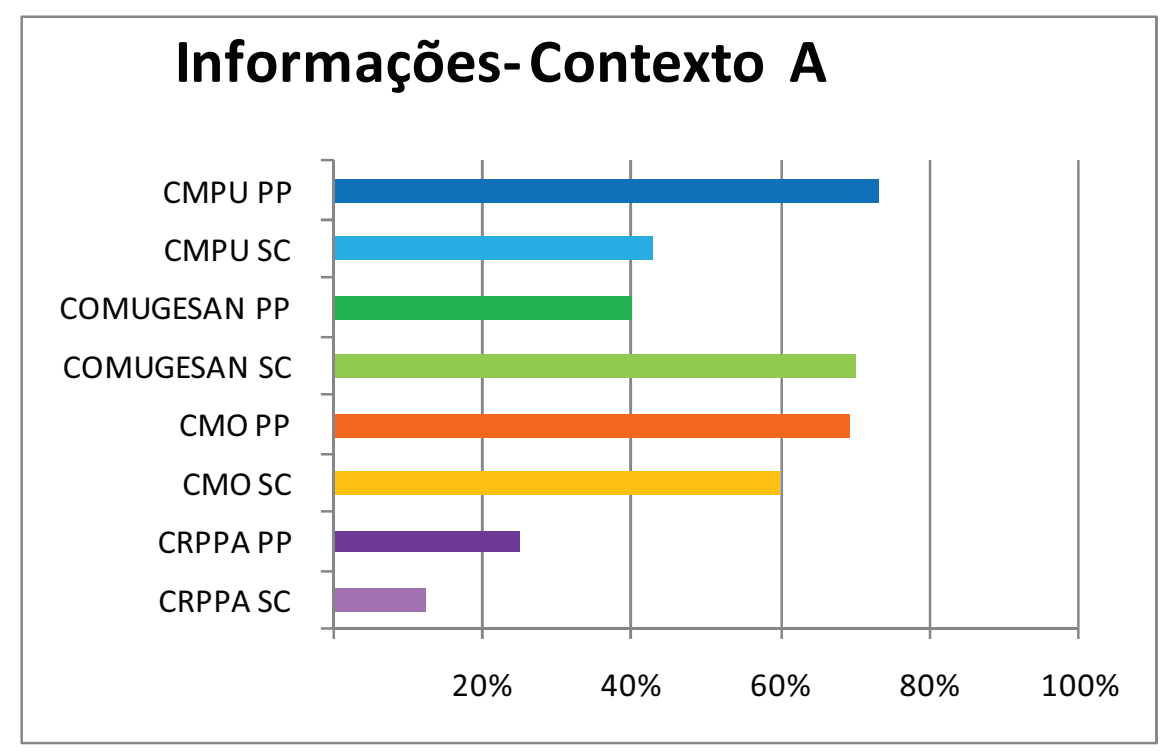

Gráfico 39: Informações - Contexto A Fonte: Vendramini, 2010.

Informações - Contexto B: Não, os conselheiros não são suficientemente informados para participar do conselho; 


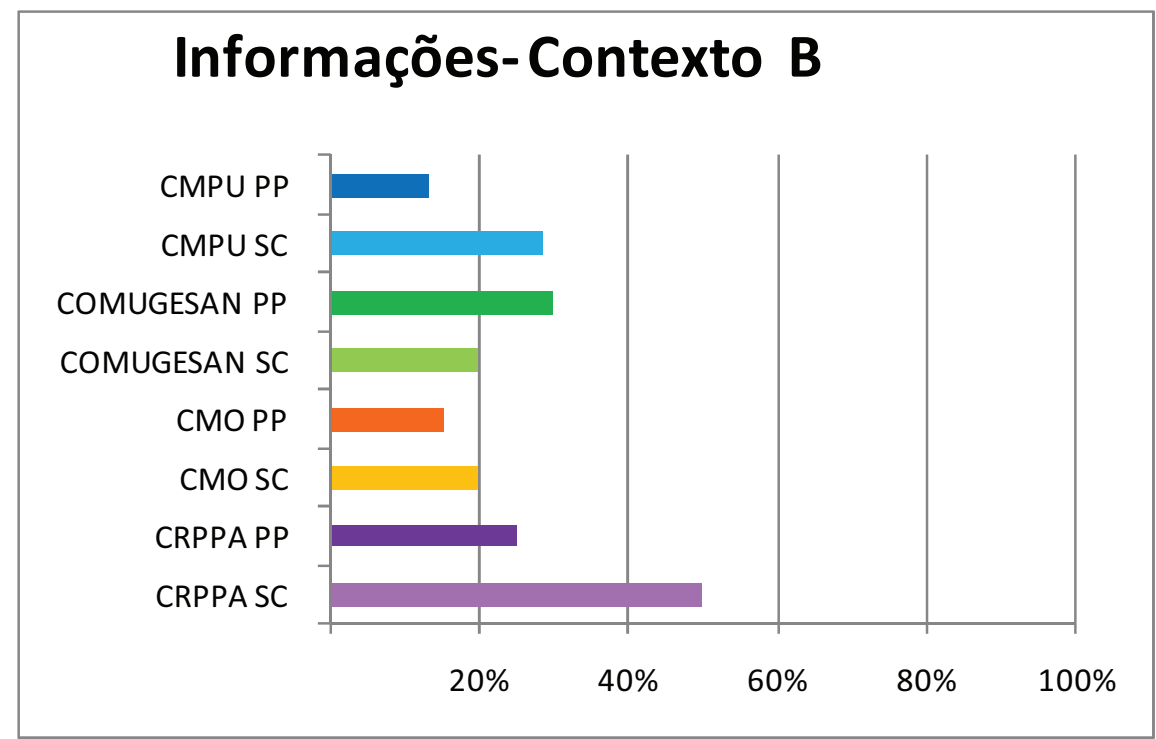

Gráfico 40: Informações - Contexto B

Fonte: Vendramini, 2010.

Informações - Contexto C: Sim, a capacitação dada no conselho cumpre este papel;

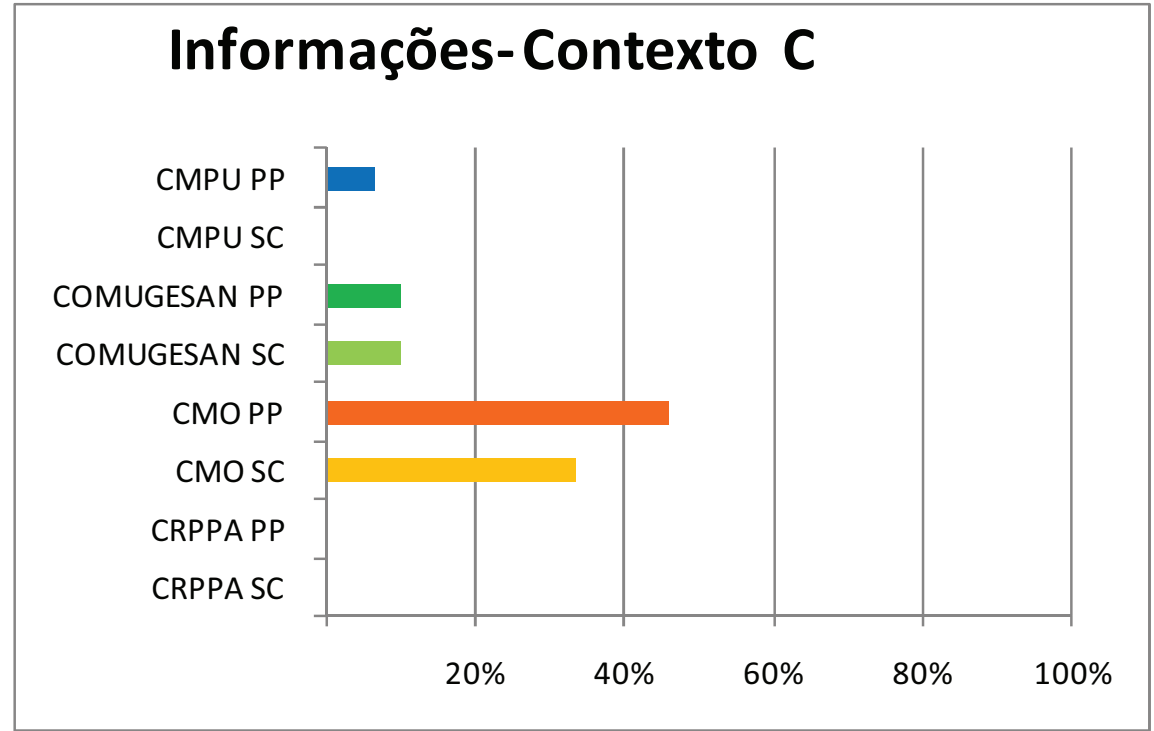

Gráfico 41: Informações - Contexto C

Fonte: Vendramini, 2010.

Informações - Contexto D: Não, o processo de transmissão de informações do poder público para os conselheiros da sociedade civil é deficiente. 


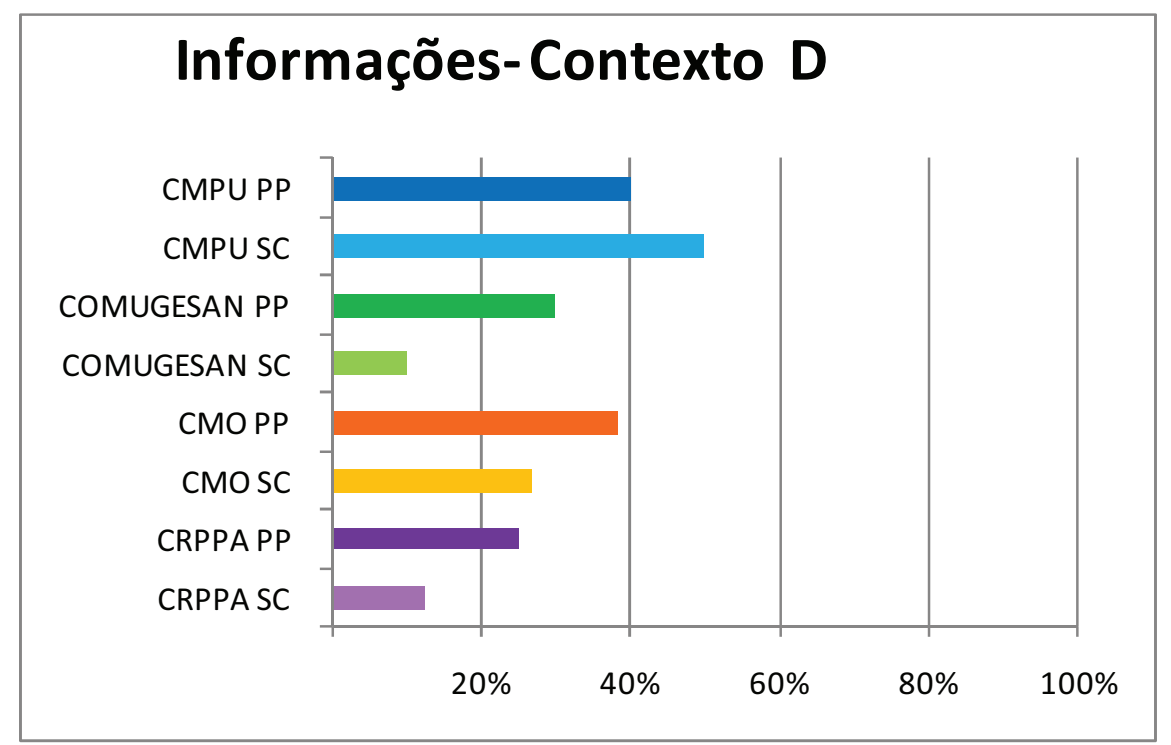

Gráfico 42: Informações - Contexto D

Fonte: Vendramini, 2010.

Com exceção do CRPPA, existem mais conselheiros que acreditam que existe informação suficiente para a participação no conselho do que os que pensam que não existe, embora estes primeiros não sejam maioria em todas as representações. Nota-se que a capacitação interna como provedora dessas informações foi bastante citada no CMO, mesmo não tendo sido perguntado diretamente sobre ela, o que aponta para um alto grau de eficiência deste processo. Por outro lado, a capacitação interna, ainda valendo a ressalva de que não foi perguntado diretamente sobre ela, foi muito pouco citada no CMPU e no COMUGESAN, o que faz questionar seus resultados.

A quantidade de repostas que apontam que os conselheiros não estão suficientemente informados para participar do conselho foi menor que as que dizem "sim", mas não foi inexpressiva. Uma situação intermediária também foi bastante mencionada, como apresentado no Contexto D. 
4.4.8 Questão 12 - Como você se mantém Informado para Participar do Conselho?

CMPU • poder público

Dentre os 15 membros do governo no CMPU que deram respostas válidas para estas questões, seis (40\%) afirmam que se mantém informados para participar das reuniões através do material oficial, como as pautas, atas, relatórios, entre outros. Quatro (27\%) disseram que trabalhar ou morar na cidade faz com que se mantenham informados, e outros quatro (27\%) dizem que buscam informações de maneira ativa.

"[...] São questões ligadas à cidade, ligadas à própria administração que muitas delas a gente tem convivência no dia a dia".

"Normalmente pela pauta que é colocada para a próxima reunião. Quando tem algum tema polêmico, sempre se requisita uma apresentação de alguém, ou de universidade, ou de outros países, outra cidade que venham expor aquele assunto: como está sendo feito, qual o critério usado $[\ldots]^{\prime \prime}$.

CMPU $\cdot$ sociedade civil

Entre os 14 representantes da sociedade civil no CMPU, sete (50\%) afirmam que se mantêm informados através do material oficial, como as atas, pautas e relatórios. Apenas um (7\%) diz que, pelo fato de morar ou trabalhar na cidade, tem acesso à informação. Seis (43\%) mencionaram que se posicionam de forma ativa para conseguir as informações necessárias, enquanto apenas um (7\%) mencionou a capacitação interna.

"Primeiro porque o conselho nos dá, antes das reuniões, ele manda a pauta informativa da próxima reunião. Quais são as discussões que vai ter nela, quais são os assuntos. Isso ele manda tudo certinho. Então você tem que 
estudar isso em casa. Não vai pegar isso e guardar na gaveta. Os conselheiros que estudam isso. Que pegam essas apostilas, então eles ficam atentos, eles aprendem e conseguem. Você tem também no começo, a gente foi fazer o curso, eles deram o material de outorga onerosa, se não me falha a memória, que foi dado a apostila [...] então você tem a apostila, você tem algumas coisas na mão para você também estudar [...] eles não deixam você em branco".

CMPU

No CMPU tanto os representantes do governo, quanto os da sociedade civil têm duas formas de se manter informados: o material oficial do conselho e o movimento de buscar as informações que sente necessidade. Os membros do poder público no conselho mencionam mais que o fato de trabalhar na cidade (ou morar) ajuda a mantê-lo informado, o que parece obvio, uma vez que o objeto de trabalho deles é justamente a administração pública.

COMUGESAN - poder público

Das 10 respostas válidas no CMPU para estas questões, seis (60\%) afirmam que utilizam o material oficial para se manter informados e quatro (40\%) dizem que o fato de trabalhar e morar no município auxilia nesse processo. Nenhum membro desta representação disse buscar ativamente por informações ou apontou a capacitação interna como fonte de dados.

"Nós recebemos uma memória de todas as reuniões que a gente participa e, em alguns momentos, a gente participa desse trabalho. Então, dessa maneira a gente está sempre ativo no conselho e recebe e partilha das informações necessárias". 
"Eu me mantenho informado porque eu estou dentro da área de meio ambiente".

COMUGESAN $\cdot$ sociedade civil

Na sociedade civil participante do COMUGESAN foram dadas 10 respostas válidas. Seis $(60 \%)$ delas apontam o material oficial do conselho como provedor de informações. Apenas duas outras respostas foram dadas a esta questão: um conselheiro (10\%) afirmou que o fato de morar ou trabalhar na cidade o mantém informado e outro disse que procura informações de forma ativa.

"Recebo informação, correspondência, correspondência eletrônica, postagem, tenho outros colegas que participam que defendem outras entidades, que a gente conversa muito, interage. Quer dizer, informação não falta".

\section{COMUGESAN}

No COMUGESAN o material oficial tem uma importância extrema na informação dos membros do conselho (60\% dos conselheiros), enquanto o processo de capacitação não foi citado nenhuma vez. Novamente os representantes do poder público deram um destaque ao fato de trabalharem (ou morarem) no município (40\%) maior que os da sociedade civil (10\%), o que seria esperado. Chama a atenção o fato de os conselheiros pouco manifestarem a busca ativa por informações, seja na própria prefeitura, na mídia, com amigos, ou através de qualquer outro meio.

CMO * poder público

$\mathrm{Na}$ representação do governo no CMO foram dadas 13 respostas válidas. Destas, seis (46\%) apontam o material oficial como provedor de informações para a participação nas reuniões do conselho. 
Outros seis membros destacam que o fato de trabalhar ou morar no município contribui para o nível de informação que apresenta e, apenas dois (15\%) dizem que procuram se manter informados de forma ativa.

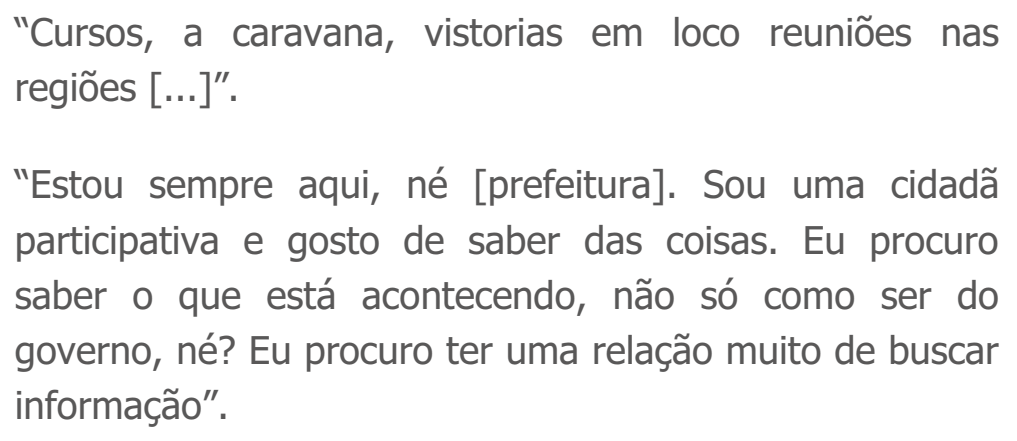
participativa e gosto de saber das coisas. Eu procuro saber o que está acontecendo, não só como ser do governo, né? Eu procuro ter uma relação muito de buscar informação".

CMO $\cdot$ sociedade civil

Dos 15 representantes da sociedade civil no CMO com respostas válidas para estas questões, nove (60\%) afirmam que o material oficial os mantém informados. Quatro (27\%) disseram que buscam as informações que necessitam de forma ativa e apenas um disse que o fato de morar ou trabalhar na cidade o mantém informado.

\footnotetext{
"São. O próprio governo liga para a gente, manda carta. O regimento interno você não pode faltar mais que três vezes senão você sai. Então, para isso nos temos calendário, o orçamento participativo liga pra gente, fala conosco, dá recado, [...] Então a gente está sempre ciente. $[\ldots]^{\prime \prime}$.

"Primeiro porque eu moro no bairro há 30 anos, conheço as pessoas do bairro, cada buraco lá que sobrevive às várias administrações eu sei, cada aniversário de buraco eu vou lá e boto uma cruzinha. Eu conheço as pessoas, eu conheço a cidade, eu conheço o grupo que está no poder lá desde 1980, 79. [...] além de Assistir os canais de televisão da região $[. . .]^{\prime \prime}$.
} 
$\mathrm{CMO}$

Assim como nos conselhos anteriores, o material oficial tem um impacto positivo na informação dos conselheiros. Os membros do poder público se beneficiam do fato de trabalharem ou morarem na cidade, como não poderia deixar de ser, e alguns membros do conselho (15\% do poder público e $27 \%$ da sociedade civil) buscam ativamente por informações.

CRPPA · poder público

No CRPPA, dos oito conselheiros que deram respostas válidas para estas questões, sete (88\%) dizem que se mantêm informados através do material oficial. Três (38\%) dizem que se beneficiam do fato de morar ou trabalhar na cidade e apenas dois (25\%) afirmam que buscam informações de forma ativa.

\footnotetext{
"Chega dentro de um envelope com a pauta e eu acho que vem a ata, eu não me lembro se vem ata, eu acho que não".

"Da prefeitura, jornal. - Não, porque as reuniões são mensais né, então nós temos as reuniões e além das reuniões do Conselho, em Paranapiacaba e Parque Andreense tem duas câmaras técnicas que funcionam para os conselheiros para assuntos específicos desses bairros. Então aí você tem mais duas reuniões mensais, e eu acompanho, então você acompanha de perto o que está acontecendo".
}

CRPPA $\cdot$ sociedade civil

Dentre os conselheiros da sociedade civil que deram respostas válidas a estas questões (oito), três (38\%) dizem que o material oficial do conselho, como a pautas, atas e relatórios, os mantém informados e quatro (50\%) buscam ativamente por informações. 


\begin{abstract}
"Ah... ah, eu além das reuniões dos conselhos né que eu faço parte é conversando com outras pessoas que... amigos que a gente acaba deixando no meio da... e informação de rádio, TV, internet".

"Eles sempre mandam relatório, as atas de todas as reuniões, todas as atividades que é feita em Paranapiacaba eles mandam todos os panfletos tudo pra nós tá acompanhando, ter um pouquinho de paciência pegar ler participar até pra você vim pra uma reunião e já tem mais ou menos uma noção. $\mathrm{E}$ isso aí tem muitos conselheiros não tem essa habilidade entendeu, eles chega entrega na casa, que a prefeitura vai e entrega, deixa em cima do armário e não lê, aí depois na reunião não tá nem sabendo o que tá acontecendo".
\end{abstract}

CRPPA

No CRPPA há uma diferenciação maior entre poder público e sociedade civil na forma de adquirir informações. Os representantes do governo se baseiam mais fortemente no material oficial, enquanto os representantes dos moradores buscam ativamente por informações. Os membros do poder público demonstram facilidade em se manter informados justamente por trabalharem ou morarem no município.

Considerações

De todas as respostas para: "Como você se mantém informado para participar do conselho?' foram identificados quatro contextos principais, que são apresentados na tabela 8 e nos gráficos 43 a 46 . 
Tabela 8: informações no conselho • contextos (continuação)

\begin{tabular}{|c|c|c|c|c|c|}
\hline & $\begin{array}{c}\text { respostas } \\
\text { válidas }\end{array}$ & $\begin{array}{c}\text { Informações } \\
\text { Contexto E }\end{array}$ & $\begin{array}{c}\text { Informações } \\
\text { Contexto F }\end{array}$ & $\begin{array}{c}\text { Informações } \\
\text { Contexto G }\end{array}$ & $\begin{array}{c}\text { Informações } \\
\text { Contexto H }\end{array}$ \\
\hline CMPU PP & 15 & 6 & 4 & 0 & 4 \\
\hline CMPU SC & 14 & 7 & 1 & 1 & 6 \\
\hline COMUGESAN PP & 10 & 6 & 4 & 0 & 0 \\
\hline COMUGESAN SC & 10 & 6 & 1 & 0 & 1 \\
\hline CMO PP & 13 & 6 & 6 & 0 & 2 \\
\hline CMO SC & 15 & 9 & 1 & 0 & 4 \\
\hline CRPPA PP & 8 & 7 & 3 & 0 & 2 \\
\hline CRPPA SC & 8 & 3 & 0 & 0 & 4 \\
\hline
\end{tabular}

Fonte: Vendramini, 2010.

Informações - Contexto E: o conselheiro se mantém informado através das atas, pautas, relatórios, telefonemas, reuniões. Para este conselheiro, na maioria das vezes, manter-se informado é saber quando, onde e para que será realizada cada reunião;

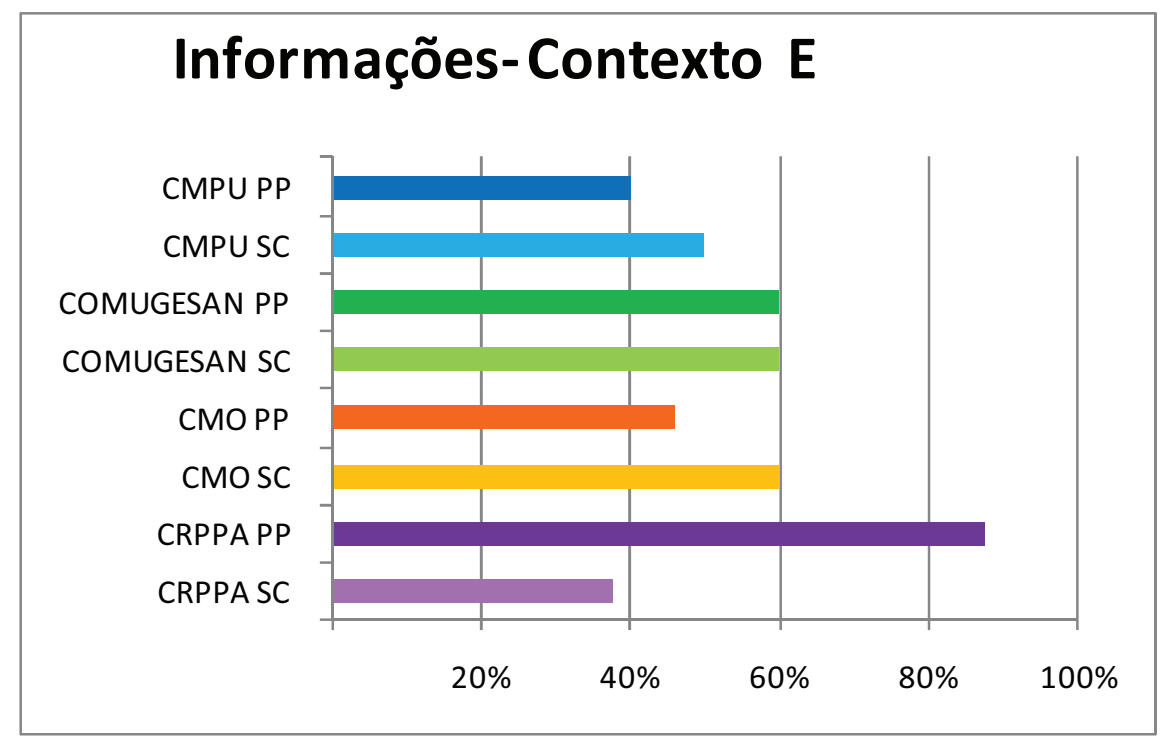

Gráfico 43: Informações - Contexto E Fonte: Vendramini, 2010.

Informações - Contexto $\mathrm{F}$ : o conselheiro se mantém informado pois mora e/ou trabalha no município; 


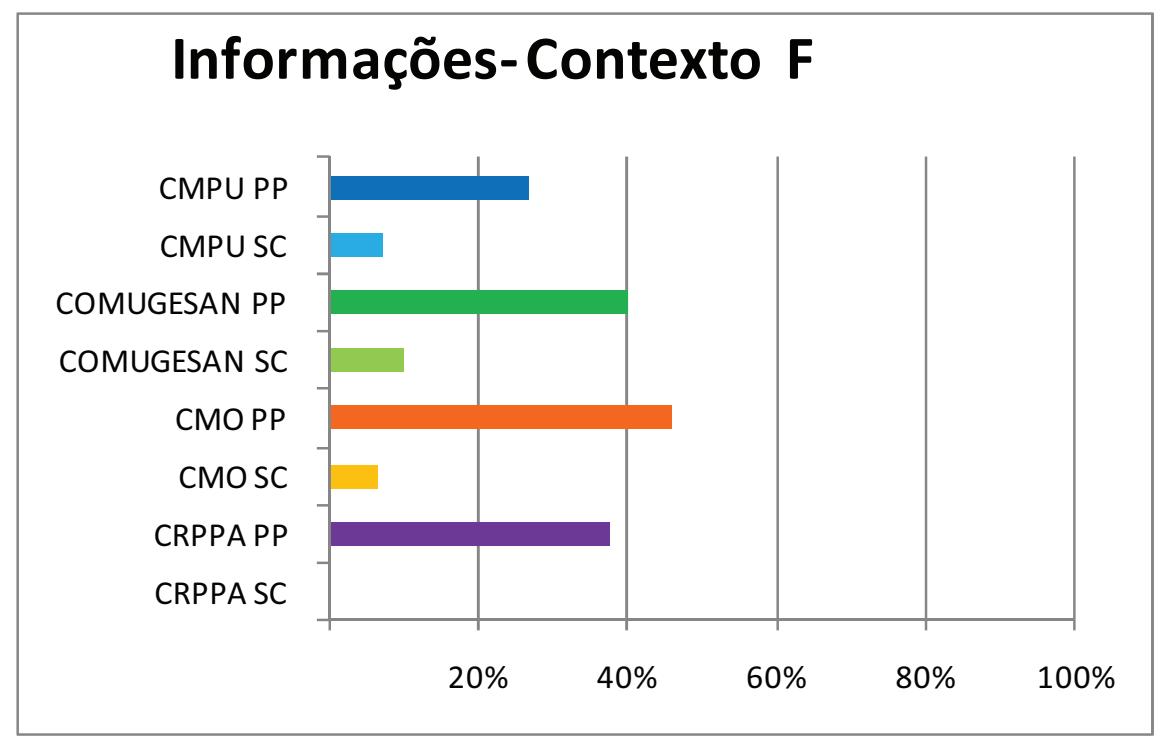

Gráfico 44: Informações - Contexto F Fonte: Vendramini, 2010.

Informações - Contexto G: a capacitação interna mantém o conselheiro suficientemente informado;

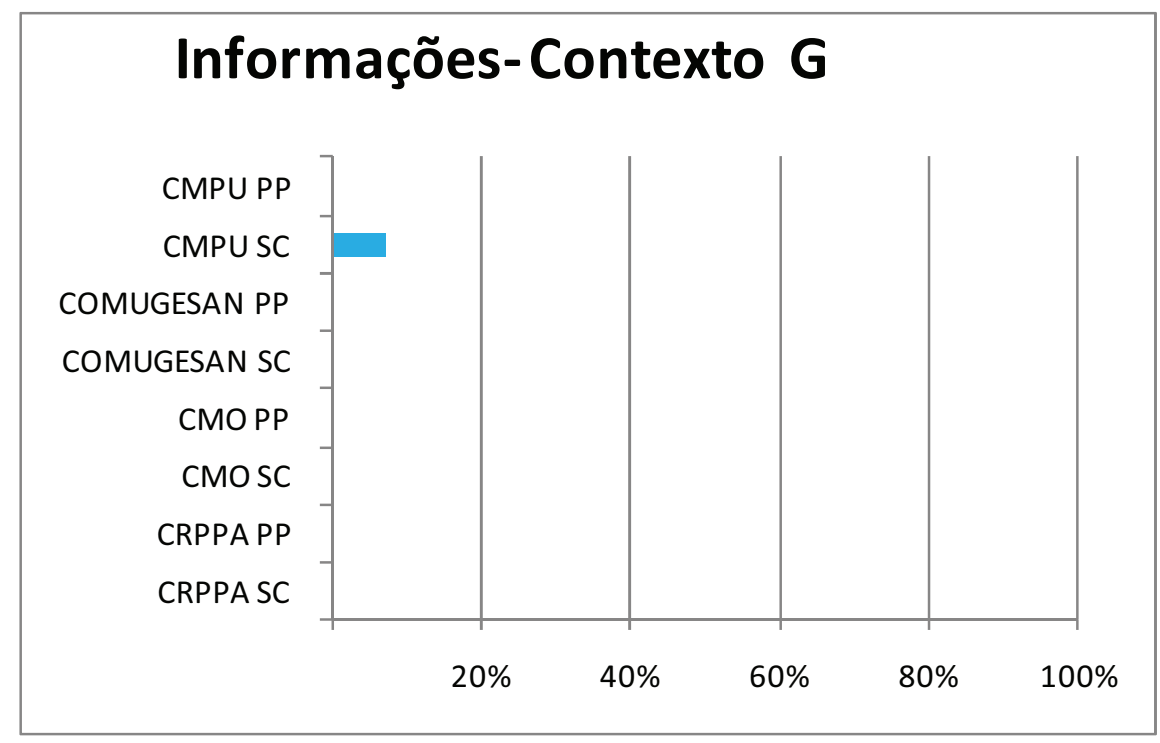

Gráfico 45: Informações - Contexto G Fonte: Vendramini, 2010.

Informações-Contexto H: o membro do conselho se posiciona ativamente para se manter informado buscando informações na prefeitura, na mídia, conversando com amigos, entre outras formas. 


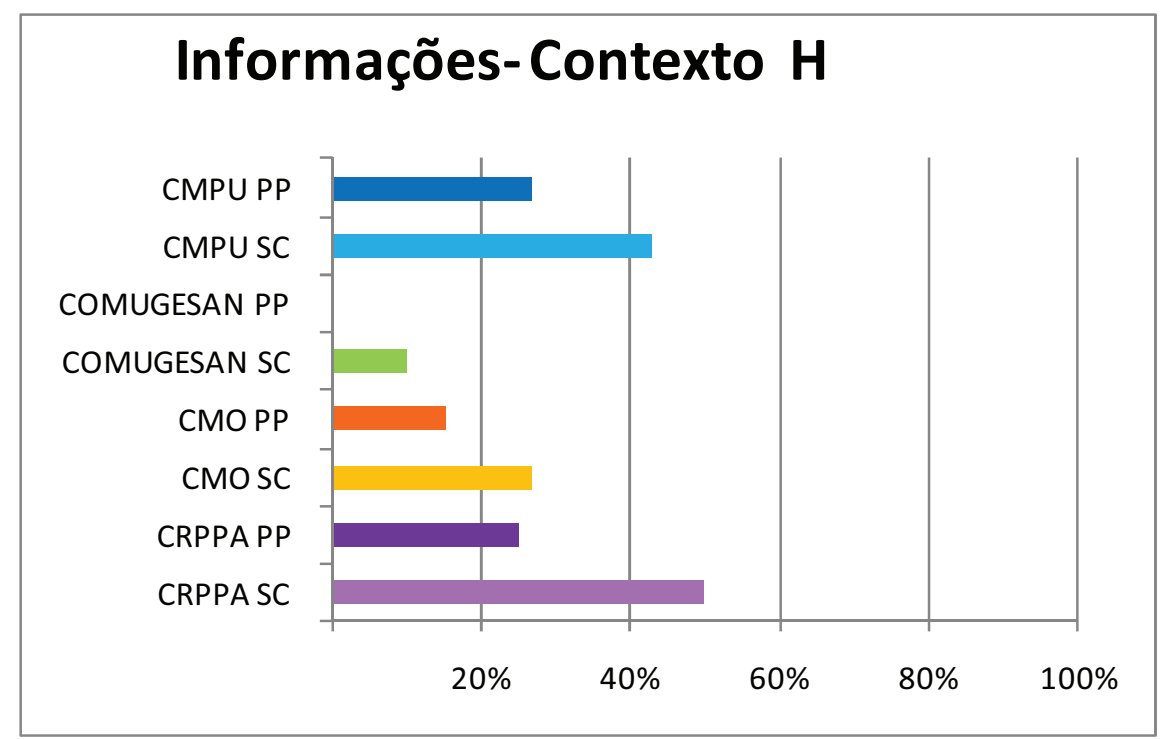

Gráfico 46: Informações - Contexto H

Fonte: Vendramini, 2010.

Os membros dos quatro conselhos estudados se apóiam fortemente no material oficial dos conselhos para se manter informados. Isto aparece nos quatro colegiados em suas duas representações no Contexto E. o Contexto $\mathrm{F}$ evidencia, como não poderia deixar de ser, que os funcionários públicos têm mais acesso à informação simplesmente pelo fato de trabalharem na prefeitura. Existe uma busca ativa por informações, sempre mais evidente entre os representantes da sociedade civil nos quatro conselhos. Eles procuram os dados que necessitam entre seus colegas do poder público, na mídia, com amigos, entre outras formas, como explicitado no Contexto $\mathrm{H}$.

O Contexto G só teve uma resposta. Diz respeito ao processo de capacitação interno aos conselhos como provedor de informação, citado por apenas um membro da sociedade civil no CMPU. Três conselheiros do governo no CMPU, em momentos distintos da análise destas respostas, dizem que o conselho provê palestras temáticas sempre que um assunto novo surge na pauta ou nas discussões internas. 
4.4.9 Questão 13 - Que tipo de Informação você acha que os Conselheiros deveriam receber para Melhorar a Qualidade de sua Participação no Conselho?

Diversas respostas distintas foram dadas para esta questão, para que não fosse perdida a diversidade e para que não fossem construídos inúmeros contextos com apenas uma resposta, optou-se por enumerá-las:

- uma visão macro do município;

- informações de outros órgãos, conselhos e municípios;

- informações técnicas;

- capacitação técnica;

- balanços internos;

- melhoria dos processos internos;

- assuntos diversos de acordo com as discussões;

Assim, as respostas mais freqüentes foram presentes nos dois conselhos reivindicativos: CMO e CRPPA, e serão apresentadas a seguir:

CMO * poder público

Entre as 13 respostas validadas dadas a estas questões no CMO, cinco (38\%) afirmam que os membros do conselho deveriam ser informados sobre a máquina do governo e o funcionamento do conselho e dois (15\%) dizem que os conselheiros deveriam saber o valor do orçamento.

\footnotetext{
"Olha, algumas coisas são chave realmente, né. Tipo assim, a totalidade do orçamento que a gente acaba investindo no orçamento participativo. É uma coisa que não tinha, né, e isso acabava me incomodando enquanto agente de participação cidadã e depois como conselheiro, né $[\ldots]^{\prime \prime}$.

"Por exemplo [...] o volume de investimento que a gente tem recebido de outras esferas de governo $[\ldots] "$.
} 
CMO $\cdot$ sociedade civil

Dos 15 membros da sociedade civil no CMO com respostas válidas, três (20\%) dizem que os conselheiros deveriam ser informados através de prestações de contas. Dois (13\%) pensam que os membros do conselho deveriam conhecer melhor o funcionamento da máquina do governo e do conselho e outros dois dizem que o valor do orçamento deveria ser informado.

\footnotetext{
"Sim, eu acho que falta transparência nas prioridades do governo. Eu diria que se claramente antes do que vai fazer, qual é a proposta de cada secretaria. Porque depois mistura tudo. Tem demanda que é do governo e que é da população e eles colocam como se fosse só da população. E quando é só da população e o governo não tem interesse, eles cortam. Isso para quem está um pouco mais no outro nível, percebe, né? Não estou dizendo nível intelectual, não. É de percepção mesmo [...]".

"[...] você não sabe qual é o orçamento da cidade".
}

$\mathrm{CMO}$

Os membros da sociedade civil no CMO sentem falta de mais prestação de contas. Nas duas representações, mas, principalmente entre os conselheiros do governo, foi mencionado que o funcionamento do governo e do conselho deveria ser informado aos conselheiros. Nota-se que alguns participantes, tanto do poder público quanto da sociedade civil sentem falta de conhecer o valor do orçamento.

CRPPA $\cdot$ poder público

Entre os oito membros do poder público do CRPPA que deram respostas válidas a estas questões, três (38\%) dizem que seria importante informar sobre o funcionamento da máquina e do conselho e dois 
(25\%) afirmam que deveriam ser realizadas prestações de contas aos conselheiros.

\begin{abstract}
"Eu acho que em primeiro lugar é conhecer como é que funciona o poder público, o que é competência dele. Porque às vezes eles confundem o que é competência que é do Governo Federal ou do Estado e eles acham que a competência é do município. Eu acho que primeiro pra conhecer as competências, e depois conhecer todos os projetos que tem na cidade, porque embora sendo afastado de uma região ela faz parte de uma cidade, então eu acho que o primeiro passo eles deviam estar conhecendo o funcionamento mesmo, a competência de cada secretaria de cada departamento pra poder, até para eles poderem encaminhar seus, suas demandas já ter canais mais... né, já fica mais dirigido".

"Olha, eu acho, lá eu gostaria de receber mais a coisa assim olha - como que a gente está fazendo, o que está acontecendo. Por exemplo, eu fui lá e ia iluminar não sei quantas ruas, um espaço aqui que fica tudo escuro, tananá, tananá, eu não sei se isso foi feito ou não. [...] acho que não seria o caso de pedir, seria assim é uma informação que o conselheiro tem que ter pra acompanhar".
\end{abstract}

CRPPA $\cdot$ sociedade civil

Na sociedade civil do CRPPA houve oito respostas válidas. Destas apenas uma (13\%) menciona que deveria ser informado aos conselheiros o funcionamento da máquina do governo e do conselho.

CRPPA

Para os membros do CRPPA é necessário que seja explicado aos conselheiros o funcionamento do governo e do conselho. Apenas duas pessoas do poder público disseram que seria importante prestar contas das ações do governo, no caso da SPPA, aos conselheiros. 
"Eu acho que se a gente tivesse alguns cursos né pra gente participar, tivesse algumas pessoas interessadas e investir nisso e chegar e pegar o representante e mostrar pra eles tudo o que precisa fazer pra acompanhar né e de que forma se pode acompanhar, eu acho que seria bem legal né, até melhoraria a atuação $[\ldots] "$..

Considerações

De todas as respostas para: "Que tipo de informação você acha que os conselheiros deveriam receber para melhorar a qualidade de sua participação no conselho?' foram identificados três contextos principais, que são apresentados na tabela 9 e nos gráficos 47 a 49 .

Tabela 9: informações no conselho • contextos (continuação)

\begin{tabular}{|c|c|c|c|c|}
\hline & $\begin{array}{c}\text { respostas } \\
\text { válidas }\end{array}$ & $\begin{array}{c}\text { Informações } \\
\text { Contexto I }\end{array}$ & $\begin{array}{c}\text { Informações } \\
\text { Contexto J }\end{array}$ & $\begin{array}{c}\text { Informações } \\
\text { Contexto K }\end{array}$ \\
\hline CMPU PP & 15 & 0 & 0 & 0 \\
\hline CMPUSC & 14 & 0 & 0 & 0 \\
\hline COMUGESAN PP & 10 & 0 & 0 & 0 \\
\hline COMUGESAN SC & 10 & 0 & 0 & 0 \\
\hline CMO PP & 13 & 0 & 5 & 2 \\
\hline CMO SC & 15 & 3 & 2 & 2 \\
\hline CRPPA PP & 8 & 2 & 3 & 0 \\
\hline CRPPA SC & 8 & 0 & 1 & 0 \\
\hline
\end{tabular}

Fonte: Vendramini, 2010.

Informações - Contexto I: o conselheiro sente falta de receber prestação de contas periódicas por parte da prefeitura; 


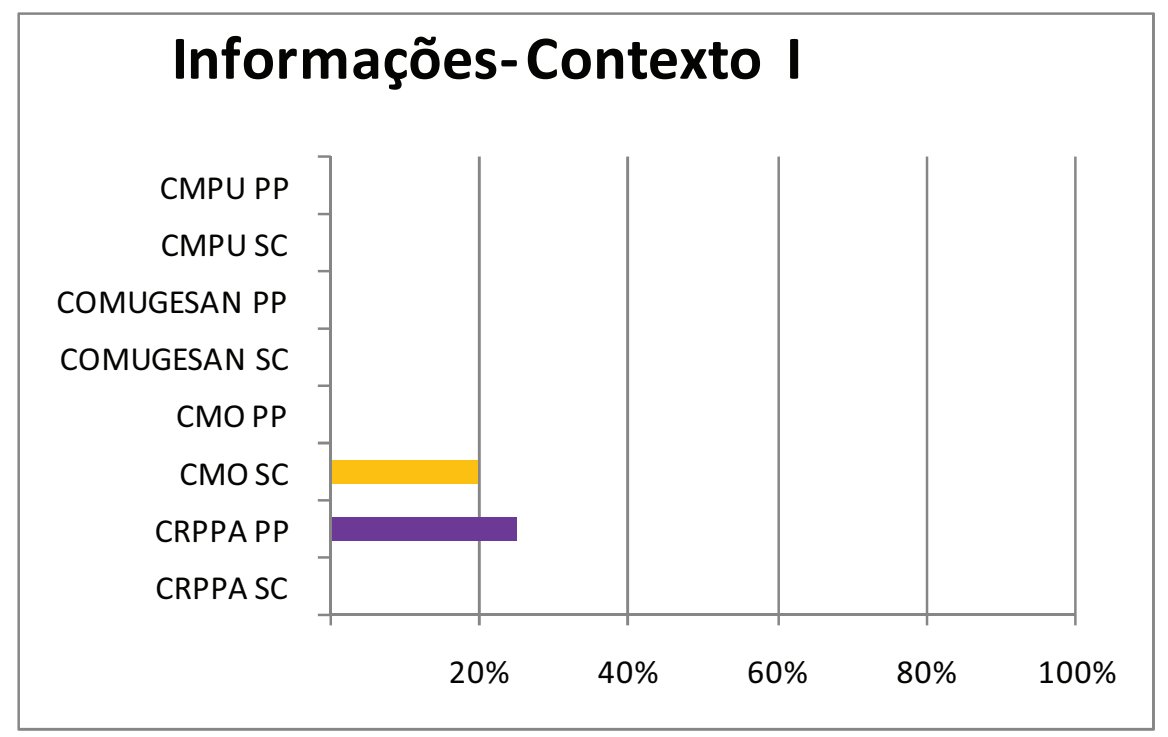

Gráfico 47: Informações - Contexto I

Fonte: Vendramini, 2010.

Informações - Contexto J: agrupa os conselheiros que sentem falta de informações sobre o funcionamento do governo e do conselho;

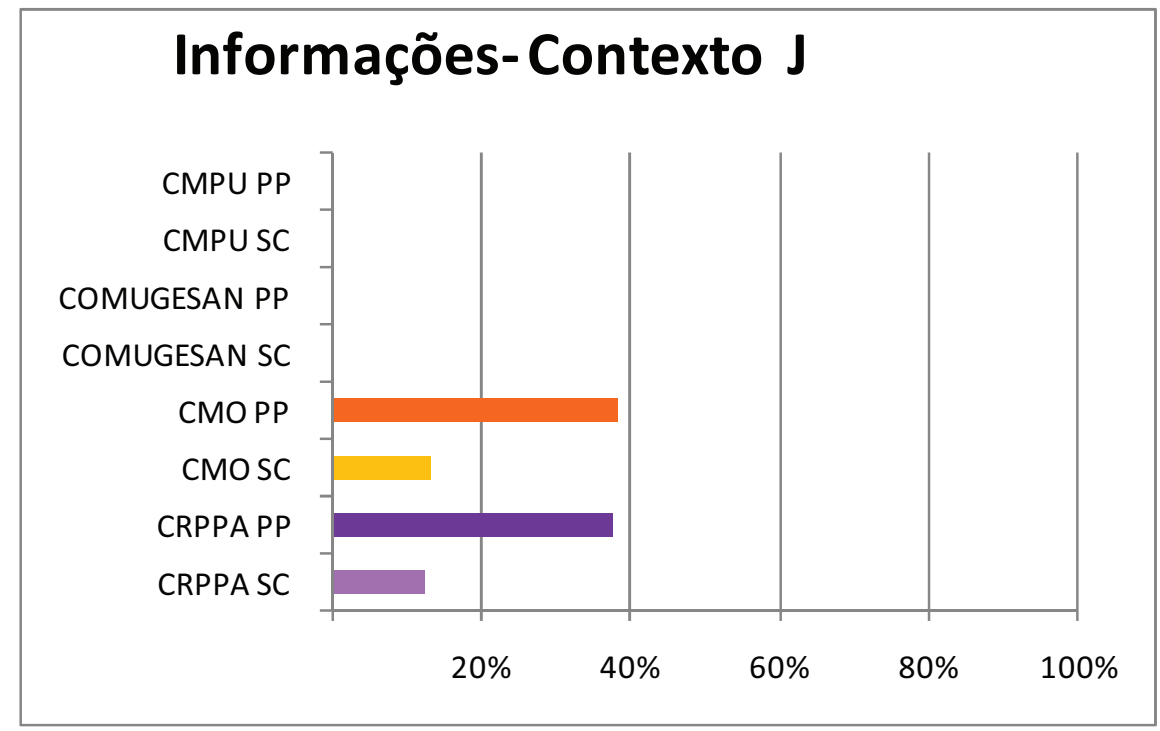

Gráfico 48: Informações - Contexto ]

Fonte: Vendramini, 2010.

Informações - Contexto K: composto pelos conselheiros que gostariam de receber informações sobre o valor do orçamento. 


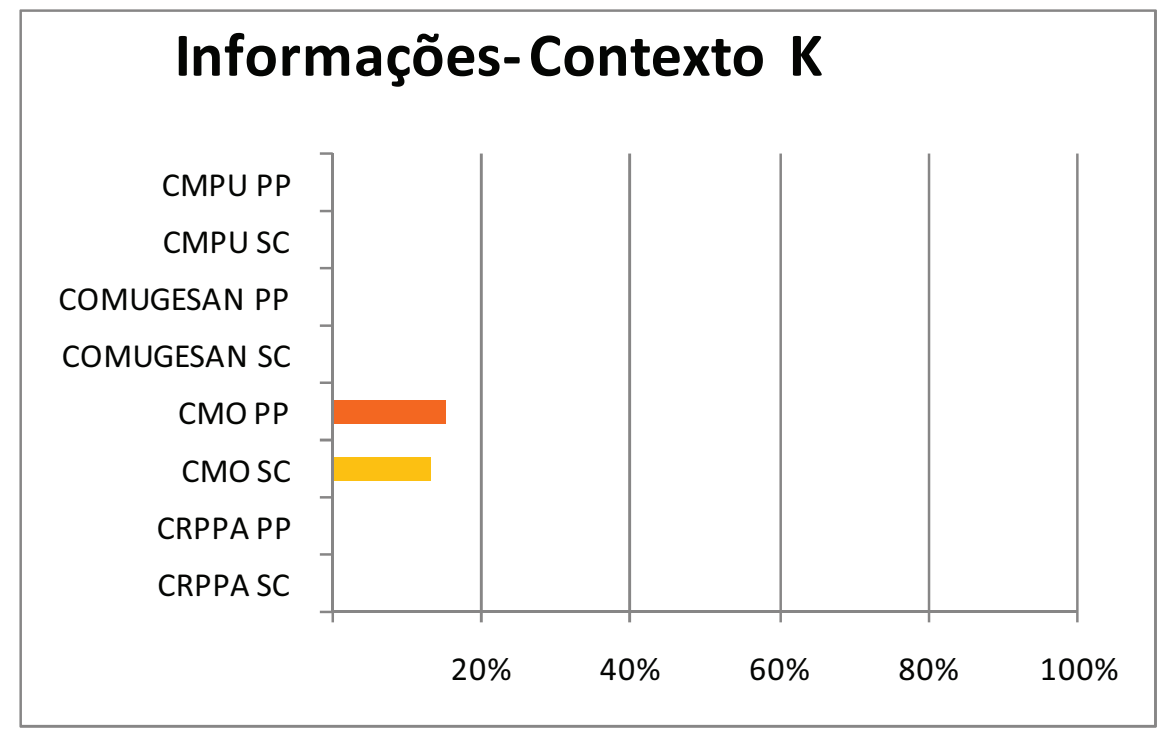

Gráfico 49: Informações - Contexto K Fonte: Vendramini, 2010.

Nota-se que, para esta questão, surgiram diversas respostas importantes, mas que não há um consenso. As respostas foram bastante esparsas e pouco freqüentes. A demanda pelo valor do orçamento é um dado que aparece apenas no $\mathrm{CMO}$, conselho que delibera sobre o orçamento municipal e que não conhece o montante com que trabalha. As respostas dadas podem ser encaradas como um rol de sugestões para os conselhos.

- uma visão macro do município;

- informações de outros órgãos, conselhos e municípios;

- informações técnicas;

- capacitação técnica;

- balanços internos;

- melhoria dos processos internos;

- assuntos diversos de acordo com as discussões;

- prestação de contas;

- funcionamento da máquina do governo e do conselho;

- o valor do orçamento (CMO). 
4.4.10 Questão 14 - De que forma estas Informações poderiam chegar até os Conselheiros?

CMPU • poder público

Dentre os 15 representantes do governo no CMPU que deram respostas válidas a estas questões, quatro (27\%) pensam que os conselheiros deveriam ir atrás das informações de que sentem falta. Três (20\%) dizem que a melhor forma é a oficial já existente: as atas, pautas, relatórios, entre outras e dois (13\%) pensam que deveriam ser dadas em alguma forma de capacitação.

\begin{abstract}
"Eu acho que cada um deve buscar. Eu acho que as informações passadas já são suficientes, mas se tiver alguma a mais, eu acho que os conselheiros interessados naquele tema específico, naquela informação específica, deve ir buscar".

"Talvez você criar dentro do conselho algumas comissões que se dediquem integralmente a estar passando informações. [...] estar proporcionando periodicamente informação".
\end{abstract}

CMPU $\cdot$ sociedade civil

Entre os 14 conselheiros da sociedade civil no CMPU que deram respostas válidas a estas questões, cinco (36\%) acham que as informações deveriam ser dadas na forma de capacitação. Apenas dois (14\%) participantes acham que a melhor forma seriam as oficiais e um (7\%) diz que o conselheiro deve buscar os dados que necessita.

"Só através de cursos, não é fácil não. [...] Você tem que aprender primeiro para depois poder passa para alguém que te pergunta, né?".

"Dessa forma, quer dizer, a informação pode chegar algum material prévio que é encaminhado juntamente 
para uma reunião, isto já é feito, e o debate pode ser precedido por uma contextualização do tema.

CMPU

Nota-se que no CMPU os conselheiros do poder público delegam aos conselheiros, o papel de se manter informado de forma ativa e os membros representantes da sociedade civil gostariam de ser capacitados nos assuntos que sentem falta.

COMUGESAN · poder público

Das dez respostas válidas do poder público no COMUGESAN, poucas explicitaram a forma como as informações deveriam chegar. Dois (20\%) conselheiros dizem que os meios oficiais são a melhor forma e dois acham que os participantes devem buscar as informações de que precisam. Apenas um (10\%) diz que deveria der realizado um processo de capacitação.

"Um processo de formação mais sistematizado. A
universidade poderia ter um papel mais forte. [...] Cursos
que contribuíssem para atender os diversos atores, do
gestor público à sociedade civil [...] o próprio
empresariado, né. Cursos de curta duração, não precisa
ser um processo de graduação".

COMUGESAN $\cdot$ sociedade civil

Dentre os 10 membros da sociedade civil organizada no COMUGESAN que apresentaram respostas válidas a estas questões, três (30\%) gostariam de receber informações na forma de capacitação e outros três acham que os meios oficiais dariam conta de informar os conselheiros.

"Eu acho que está bom, porque ela vem através de e-mail e vem através de mala direta. Então mais do que isso é difícil, né?". 
"Através de um apostilado, através de um curso. Eu acho que isso ajudaria um pouco".

\section{COMUGESAN}

Assim como no CMPU, no COMUGESAN os conselheiros da sociedade civil gostariam de receber as informações que necessitam na forma de capacitação, enquanto os membros do poder público pensam que os conselheiros devem buscar as informações que necessitam. Conselheiros de ambas as representações dizem que os documentos oficiais também são uma boa forma para que as informações cheguem até eles.

CMO - poder público

Os representantes do governo do CMO deram 13 respostas válidas para estas questões. Destes, seis (46\%) afirmam que a melhor forma para que as informações cheguem aos conselheiros é a capacitação. Dois (15\%) dizem que os documentos oficiais podem cumprir esse papel e quatro (31\%) pensam que eles devem buscar as informações de que precisam.

\footnotetext{
"Eu acho que deve existir aulas, seminários, apresentações, acho que a internet, neste caso, não funciona tão bem, diferente do [outro conselho] que é outro tipo de público".

"Elas podem chegar através dos cursos, das palestras que são oferecidas para todos os conselhos, podem chegar pela busca dos conselheiros da sociedade civil das informações na prefeitura nas diversas secretarias".
}

CMO $\cdot$ sociedade civil

Foram 15 as respostas válidas para estas questões dadas pelos representantes da sociedade civil no CMO. Cinco (33\%) deles pensam que os documentos oficiais são a melhor forma para que as informações cheguem aos conselheiros; três (20\%) consideram que os conselheiros 
devem buscar as informações que necessitam e apenas dois (13\%) mencionam a capacitação como forma de obter tais informações.

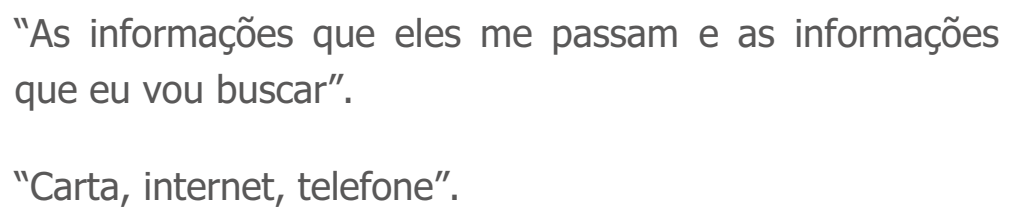

CMO

Ao contrário dos conselhos anteriores, no CMO os membros do governo, mais que os da sociedade civil, indicam a capacitação como forma de se apresentar as informações que devem ser agregadas, e os da população dizem, mais que os do poder público, que os documentos oficiais são uma boa forma de comunicação. Ambas as representações indicam a possibilidade dos membros do conselho irem buscar as informações que necessitam.

CRPPA - poder público

Foram oito as respostas válidas dadas a estas questões pelos representantes do poder público no CRPPA. Metade destes participantes (quatro - 50\%) afirma que a capacitação seria a melhor forma de distribuir as informações necessárias. Apenas um (13\%) conselheiro diz que as pessoas devem buscar os dados de que sente falta.

\footnotetext{
"[...] é quando a pessoa, o representante da sociedade civil entendendo e compreendendo o tamanho da responsabilidade e a necessidade de se capacitar ir buscar né informações de outros espaços e conferir aquilo que foi recebido".

"Talvez de uma solicitação, qualquer demanda deles de qualquer coisa de qualquer pauta de qualquer assunto a gente traz pessoas especializadas aqui né, isso sendo pautado a gente traz".
} 
CRPPA $\cdot$ sociedade civil

Novamente foram oito as respostas válidas a estas questões na sociedade civil do CRPPA. Quatro (50\%) conselheiros afirmam que eles devem buscar as informações complementares. Dois (25\%) membros dizem que devem ser utilizados os documentos oficiais e outros dois que a melhor maneira seria através de capacitação.

CRPPA

No CRPPA os membros do poder público citam mais a capacitação como forma de informar e os da sociedade civil dizem que os conselheiros devem buscar as informações que necessitam. Nenhum participante do governo cita os documentos oficiais como forma de informar para atuar no conselho.

\footnotetext{
"Eu acho que se a gente tivesse alguns cursos né pra gente participar, tivesse algumas pessoas interessadas e investir nisso e chegar e pegar o representante e mostrar pra eles tudo o que precisa fazer pra acompanhar né e de que forma se pode acompanhar, eu acho que seria bem legal né, até melhoraria a atuação e precisava realmente a gente precisava ter tempo né pra isso, então o essencial é o tempo né que a gente não tem pra funcionar".

"Você se mantém informado indo nas casas da população né, jornal".
}

Considerações

De todas as respostas para: "De que forma estas informações poderiam chegar até os conselheiros?' foram identificados três contextos principais, que são apresentados na tabela 10 e nos gráficos 50 a 52. 
Tabela 10: informações no conselho ' contextos (continuação)

\begin{tabular}{|c|c|c|c|c|}
\hline & $\begin{array}{c}\text { respostas } \\
\text { válidas }\end{array}$ & $\begin{array}{c}\text { Informações } \\
\text { Contexto L }\end{array}$ & $\begin{array}{c}\text { Informações } \\
\text { Contexto M }\end{array}$ & $\begin{array}{l}\text { Informações } \\
\text { Contexto N } \\
\end{array}$ \\
\hline CMPU PP & 15 & 2 & 3 & 4 \\
\hline CMPU SC & 14 & 5 & 2 & 1 \\
\hline COMUGESAN PP & 10 & 1 & 2 & 2 \\
\hline COMUGESAN SC & 10 & 3 & 3 & 0 \\
\hline CMO PP & 13 & 6 & 2 & 4 \\
\hline CMO SC & 15 & 2 & 5 & 3 \\
\hline CRPPA PP & 8 & 4 & 0 & 1 \\
\hline CRPPA SC & 8 & 2 & 2 & 4 \\
\hline
\end{tabular}

Fonte: Vendramini, 2010.

Informações - Contexto L: As informações deveriam chegar na forma de capacitação;

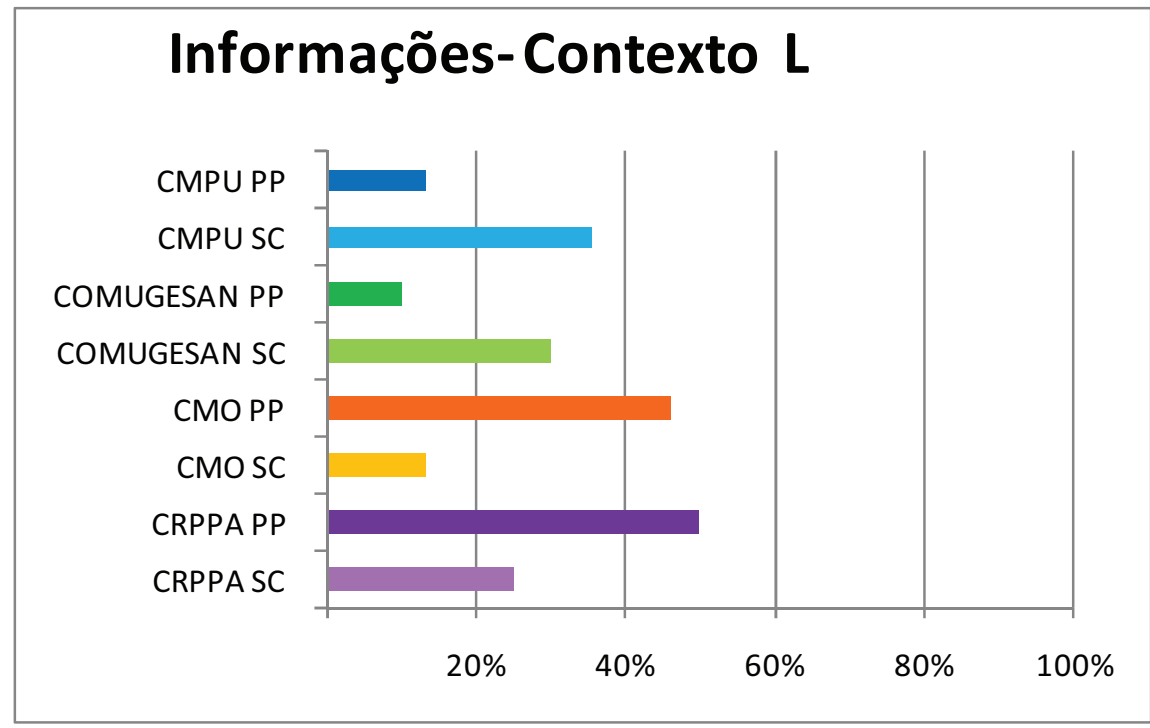

Gráfico 50: Informações - Contexto L Fonte: Vendramini, 2010.

Informações-Contexto M: A maneira atual de envio de informações poderia trazer as informações que faltam, tais como atas, pautas, relatórios, entre outros; 


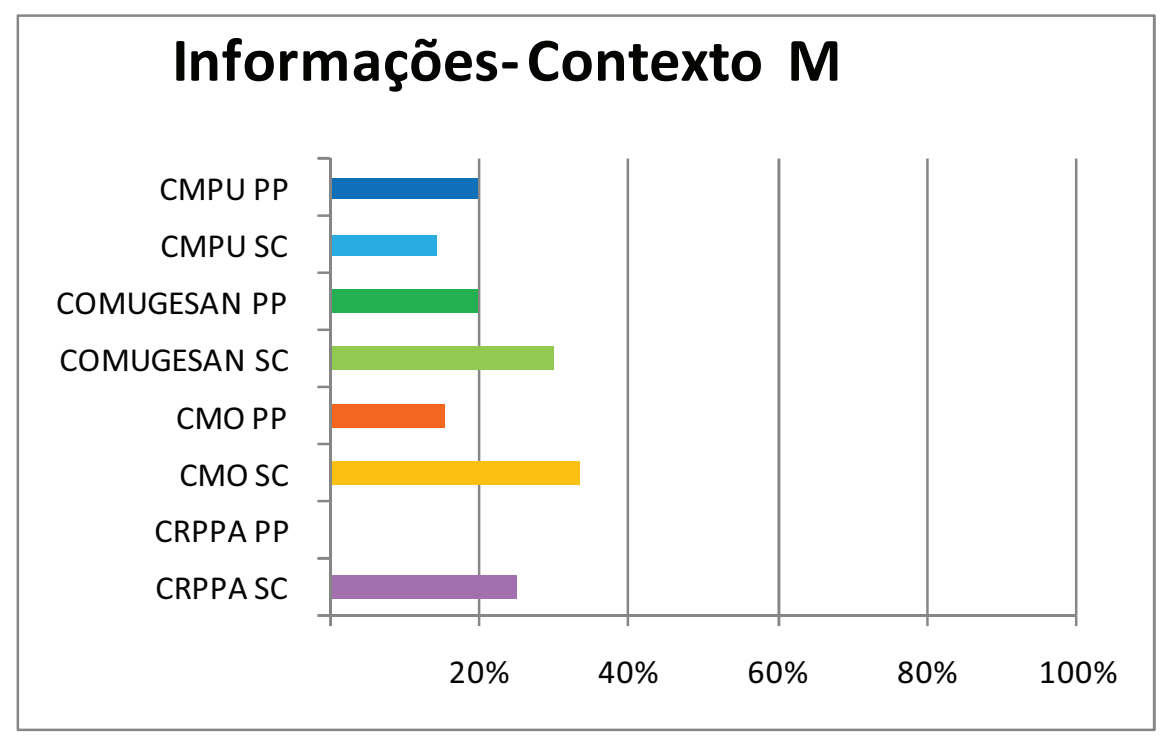

Gráfico 51: Informações - Contexto M Fonte: Vendramini, 2010.

Informações - Contexto N: O conselheiro deve buscar as informações que sente falta em locais como a mídia, as redes sociais e os eventos, por exemplo.

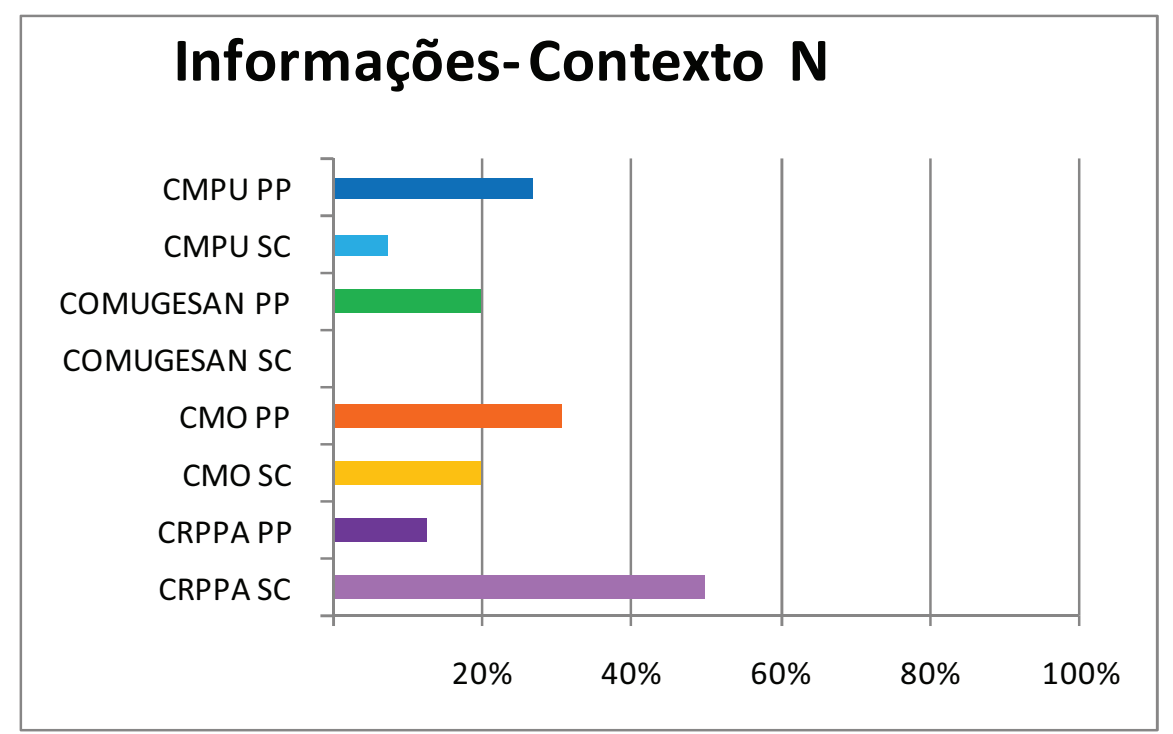

Gráfico 52: Informações - Contexto N Fonte: Vendramini, 2010.

Cabe aqui ressaltar semelhanças e diferenças. Nos dois conselhos de políticas públicas, o CMPU e o COMUGESAN, os membros do poder público citam menos a capacitação como forma de informar (contexto 
L) e mais a necessidade do conselheiro buscar as informações de que necessita (Contexto $\mathrm{N}$ ). Nestes conselhos os documentos oficiais são lembrados de forma razoavelmente uniforme (Contexto $M$ ). Nos conselhos reivindicativos, o CMO e o CRPPA, os representantes do poder público apostam mais no papel da capacitação, mesmo com a diferença de existir processo de formação no CMO e não existir no CRPPA (Contexto L). Parece que o fato de os primeiros conselhos terem caráter mais técnico, a formação dos conselheiros preocupa menos os membros do poder público, mas, este conforto não aparece entre os participantes da sociedade civil.

Chama a atenção também o fato de os conselheiros do governo no CRPPA não citarem os documentos oficiais como forma de informar e de mencionarem muito pouco a postura ativa dos conselheiros em busca de informação.

\subsection{CONSIDERAÇÕES FINAIS DO CAPÍTULO}

Neste capítulo foram organizados e analisados os dados de campo colhidos para fundamentar esta tese: reconhecimento do município de Santo André, entrevistas com os gestores de políticas públicas, os regulamentos dos conselhos e as entrevistas com os conselheiros.

Pode-se notar em linhas gerais que desde 1989, com 0 primeiro mandato do ex-prefeito Celso Daniel, já após a constituição de 1988, Santo André iniciou a abertura de fóruns participativos com o orçamento participativo. Em seu segundo mandato, que teve início em 1997, foram iniciados inúmeros projetos apoiados na participação de seus cidadãos, incluindo os conselhos municipais, previstos na legislação, e que neste município têm funcionamento exemplar: reuniões mensais, quórum, 
atividades relacionadas aos seus propósitos, são paritários e deliberativos, conselheiros representantes da sociedade civil são eleitos, seu mandato respeitado e são substituídos quando não exercem suas atividades de forma assídua, conforme os regulamentos dos conselhos. Em função das inúmeras propostas participativas levadas a cabo por Santo André e dos resultados alcançados, alguns projetos foram reconhecidos em fóruns nacionais e internacionais e premiados. Por um lado, é por este motivo que diversas municipalidades se apóiam no exemplo deste município como referência para sua gestão municipal participativa. Por outro, Santo André tem dificuldades em encontrar exemplos de gestão democrática em municipalidades com características similares às suas para servir de referência para a formulação de políticas participativas.

No município de Santo André existe um forte respeito ao plano de governo, eleito com o prefeito. Para o mandato de 2005 a 2008, em estudo nesta tese, foram definidas cinco diretrizes para a formulação das políticas públicas: educação e identidade cultural; inclusão social; desenvolvimento urbano e ambiental; participação cidadã; e modernização e desenvolvimento econômico. A participação cidadã mostra-se importante como linha condutora dos trabalhos no município. Outros fatores que facilitam a gestão das políticas públicas em Santo André da forma que vem sendo realizada são a continuidade política por três mandatos consecutivos e o alto grau de instrução dos gestores municipais. Notou-se que dentre as quatro instituições pesquisadas, o SEMASA tem um funcionamento diferenciado, provavelmente por ser uma autarquia e não uma secretaria de meio ambiente. O gestor entrevistado teve dificuldade com os termos relacionados à formulação e implementação de políticas públicas. Mencionou o planejamento estratégico da instituição como forma de formulação de políticas e falou muito pouco do COMUGESAN como conselho gestor das políticas públicas ambientais. Dentre os quatro conselhos estudados, o mais citado pelos gestores de políticas de Santo André foi, sem dúvida, o CMO que 
organiza o orçamento participativo. O CMPU também foi bastante relacionado à gestão das políticas pela Secretaria de Desenvolvimento Urbano e Habitação, como era de se esperar. O monitoramento do andamento dos planos, programas e projetos decorrentes das políticas estabelecidas foi um aspecto que não pareceu estar bem resolvido e que é atribuição dos conselhos municipais.

Dos quatro conselhos, apenas dois estão regulados por lei, o COMUGESAN e o CRPPA, o que abre espaço para a dissolução do CMO e do CRPPA no caso de mudança política na troca de prefeito. Este último tem o agravante de ter um regulamento interno pouco claro. Existem relações entre conselhos materializadas de duas formas. A mais tênue abre uma cadeira para funcionários de secretarias específicas entre os representantes do poder público, trazendo para a discussão pessoas de secretarias que têm conselhos próprios e que podem, como representantes que são, fazer a comunicação entre os dois colegiados. Seria mais proveitoso se fosse requerido que estes funcionários fossem participantes dos conselhos da instituição de origem. A relação mais forte é realizada pelos representantes da sociedade civil em outros conselhos. Alguns regimentos, quando especificam as representações requeridas nos seus colegiados, separam cadeiras para membros eleitos de conselhos específicos. O CRPPA e o CMO, por exemplo, têm cadeira para um conselheiro do $\mathrm{CMO}$ e outro do COMUGESAN, como mostra a figura 50.

As entrevistas com os conselheiros trazem informações importantes sobre os quatro conselhos estudados. Elas mostram que os conselhos, de modo geral, realmente funcionam de acordo com seus regulamentos, existe discussão e deliberação em suas reuniões. Eles são canais de diálogo entre governo e sociedade civil e, segundo os membros do poder público, ampliam a transparência e são uma forma de compartilhamento do poder entre governo e sociedade civil. Porém existem problemas importantes no funcionamento destes conselhos. O CRPPA tem 
problemas de desorganização da sociedade civil, de conflitos internos e de falta de informações para a plena atuação nas reuniões. De maneira geral, os conselhos sofrem com falhas na capacitação dos conselheiros, eles realizam pouca fiscalização da ação pública, e, mais importante, as deliberações são tendenciosas, uma vez que os representantes do governo votam de acordo com o interesse do poder público, em uníssono, o que, associado à desorganização da sociedade civil tem feito com que os interesses do poder público prevaleçam. 


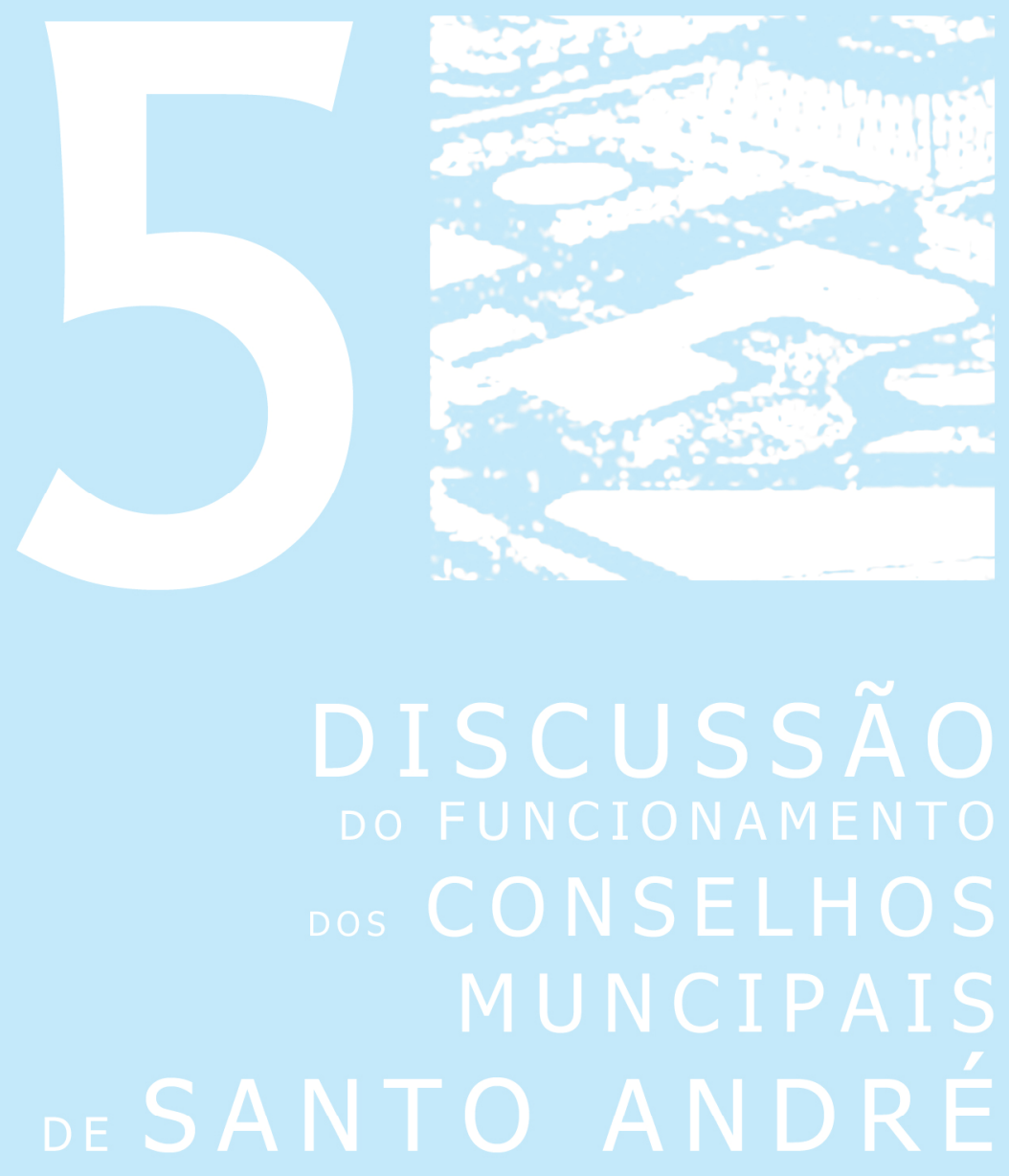



\section{DISCUSSÃO DO FUNCIONAMENTO DOS CONSELHOS MUNICIPAIS DE SANTO ANDRÉ}

Neste capítulo discutem-se os resultados da pesquisa para esta tese, buscando confirmar a hipótese de que o processo de tomada de decisão nos conselhos municipais, apesar de apresentar progressos importantes, apresenta fragilidades, mesmo em municípios que incorporam e estimulam a democracia deliberativa a partir da Constituição Federal de 1988.

Observou-se que Santo André é realmente um caso exemplar em gestão compartilhada por meio de seus conselhos em diversos aspectos. Estes conselhos têm funcionamento mensal regular, assim como suas câmaras técnicas estabelecidas; têm auxiliado na diminuição das tradicionais práticas clientelistas; neles a representatividade é exercida por seus membros, entre outros aspectos [gráficos 11, 14 e 17]. Porém, mesmo com este funcionamento exemplar, apresentam alguns entraves: ainda existem questões de falta de transparência que precisam ser resolvidas [gráficos 25 e 49]; o papel de fiscalização da ação pública não é devidamente exercido pelos representantes da sociedade civil; dentre os conselho [gráficos 15 e 26], o CRPPA tem conflitos internos importantes, que somados a problemas de logística têm esvaziado as reuniões; a capacitação dos conselheiros precisa ser criada ou ampliada conforme o caso [gráficos 41, 45 e 50]; e, mais importante, o processo decisório precisa ser revisto, pois a paridade tem, em alguns casos, dificultado que as decisões sejam de fato compartilhadas.

A Prefeitura Municipal de Santo André vem passando por sucessivas administrações com continuidade política, o que tem contribuído com a gestão participativa de suas políticas públicas. Quando o prefeito é 
eleito, o Plano de Governo é iniciado, o que é facilitado pela seqüência de administrações do mesmo partido. Deste Plano de Governo decorrem cinco diretrizes para a formulação das políticas públicas municipais: educação e identidade cultural; inclusão social; desenvolvimento urbano e ambiental; modernização e desenvolvimento econômico; e, destaca-se, a participação cidadã. Grande parte dos setores da administração municipal conta com um conselho gestor, que tem seu papel disciplinado pela Lei Orgânica Municipal (LOM) que prevê que a "Gestão Democrática dar-se-á, dentre outras formas, através da participação da população em canais institucionais denominados conselhos" (SANTO ANDRÉ, 1990). Os instrumentos administrativos são formulados em função do plano de governo e das políticas públicas de cada setor da prefeitura. O Plano Plurianual é construído para vigorar do segundo ano de mandato da administração que o cria, até o primeiro ano do mandato da administração seguinte. Nele constam as novas políticas e os planos, programas e projetos decorrentes das diversas políticas públicas do município. A lei de diretrizes orçamentárias é o detalhamento deste plano plurianual (BALCÃO; TEIXEIRA, 2003).

Os conselhos municipais de Santo André são instituídos de acordo com a LOM. Assim, os conselhos são paritários; as representações do poder público e da sociedade civil, assim como dos movimentos populares são garantidas; os mandatos dos membros da sociedade civil são de dois anos com direito a uma reeleição; existe possibilidade de renovação dos conselheiros representantes do governo quando há troca de prefeito; seus membros não recebem nenhuma forma de remuneração; as entidades e movimentos populares interessados em participar do conselho são cadastrados e eleitos por seus pares; e as reuniões são abertas à participação de todos os cidadãos, pelo menos uma vez por ano, para que haja análise do trabalho realizado e encaminhamento de propostas para 0 futuro. Além da regulamentação dada pela LOM, cada conselho tem seu regimento, e alguns têm leis específicas que normatizam seu funcionamento 
quanto a: quantidade de membros titulares e suplentes; eleição das entidades da sociedade civil que serão representadas; estrutura administrativa interna, como presidência, secretaria e grupos de trabalho; atribuições do conselho; caráter deliberativo; e freqüência das reuniões, bem como estrutura de trabalho e controle de faltas (SANTO ANDRÉ, 2008; SANTO ANDRÉ, 2005; SEMASA, 2004; SPPA, 2001?), sendo que o regimento interno do CRPPA é o menos preciso. O CMO revê seu regimento interno a cada ciclo de OP de dois anos, o que o torna mais dinâmico.

Discutindo as questões acima, observa-se que entrevistas realizadas com os conselheiros corroboram alguns daqueles aspectos. Os conselheiros afirmaram que o conselho tem o papel de propiciar o diálogo entre o poder público e a sociedade civil [gráfico 1]; que nos dois conselhos de políticas estudados são tomadas decisões sobre políticas públicas [gráfico 6]; que há participação adequada nas reuniões [gráficos 11 e 12] - com exceção dos já mencionados problemas enfrentados pelo CRPPA, que serão detalhados a diante; discutem os assuntos propostos; e exercem seu papel de representantes das organizações da sociedade civil. Claramente, ao enumerar as vantagens da existência dos conselhos [gráfico 20], o caráter de promoção da democracia participativa foi valorizado por uma parcela grande de seus membros.

Além deste funcionamento exemplar dos conselhos municipais, cabe ressaltar novamente o pioneirismo que a PMSA tem exercido quanto à adoção desses instrumentos participativos na gestão municipal, o que, por um lado, faz de Santo André um caso de estudo para outras municipalidades e, por outro, restringe a quantidade de casos que possam servir de inspiração para a administração andreense ${ }^{61}$. 61 Dado apresentado em entrevista pela gestora de políticas públicas da Secretaria de
Desenvolvimento Urbano e Planejamento de Santo André. 
A autonomia das secretarias e instituições que administram as políticas públicas municipais é limitada em função da própria estrutura da gestão municipal. Segundo um dos gestores entrevistados, autonomia é diferente de independência. Assim, o Plano de Governo é o instrumento que dita as principais políticas de governo e os conselhos são consultados sobre cada política pública a ser adotada ou um de seus desdobramentos - planos, programas ou projetos. As entrevistas com os gestores mostram que existe uma firme linha de conduta direcionando o trabalho da gestão, sem engessar as ações dos setores, cabendo a cada um destes discutir como irá contribuir com o Plano de Governo.

A pesquisa mostrou que vários resultados positivos desta forma de gestão compartilhada tornam-se claros em Santo André. As práticas clientelistas [item 4.4.3], por exemplo, foram inibidas, conforme as declarações de conselheiros do CMO, e abriu-se um caminho democrático para que as demandas da população chegassem ao poder público através das representações da sociedade civil nos conselhos. Os limites que estas práticas costumam impor à instalação e funcionamento dos conselhos, como apontado por Gohn (2007a), foram ultrapassados em Santo André.

A promoção da eqüidade tem sido atestada em pesquisas sobre o orçamento participativo. Avritzer (2002) aponta que o orçamento participativo de Porto Alegre tem demonstrado a capacidade de criar maior equidade e eficiência administrativa. Já em Santo André, os trabalhos Proyecto Incluir (2006) e de Gragnani (2007) também concluem que o orçamento participativo promove a eqüidade, comprovando que o maior volume de gastos da prefeitura, decorrentes das prioridades eleitas no OP, tem sido direcionado para as áreas com menos infra-estrutura e maior vulnerabilidade social. Outro avanço do CMO resulta do crescente volume de demandas atendidas, como foi mostrado no capítulo 4 desta tese. 
A integração da política urbana com a ambiental é essencial para a promoção da sustentabilidade urbana. Em função disto foram analisadas as relações entre os quatro conselhos estudados, conforme mostra a figura 50. Os quatro conselhos selecionados têm relação com este contexto ambiental urbano. Então, é imprescindível que eles tenham um grau satisfatório de interação. O CMPU contribui muito para isto, uma vez que tem entre seus membros representantes da sociedade civil, conselheiros do COMUGESAN e do CMO. Também tem entre os componentes da bancada do governo membros do SEMASA, SPPA e SOPP, as três instituições que gerem os outros três conselhos.

O CMO, por seu regimento, não define a instituição de origem dos membros do poder público, e os membros da sociedade civil são representantes da população, vinculados ao território, o que não permite determinar a participação em dois conselhos. A ligação entre o CMO e os demais conselhos se estabelece claramente quando seus membros são requeridos pelo regimento de outros conselhos.

O COMUGESAN requer apenas um membro do poder público representando a SPPA e outro representando a sociedade civil do CRPPA, ambos ligados à Área de Proteção e Recuperação de Mananciais, que, até 2001, era de responsabilidade do próprio SEMASA. Como via de mão dupla, o CRPPA requer representante do SEMASA e do COMUGESAN, além do representante do CMO.

Com exceção da importante ligação entre CMPU e CRPPA, que não é estabelecida, os quatro conselhos criaram canais de intercâmbio consistentes entre si, o que contribui para a desejada gestão integrada das políticas (PHILIPPI JR.; BRUNA, 2004).

No entanto, ao contrário do que se esperava na pesquisa, poucos conselheiros citaram que o conselho de que participam contribui para a transparência das ações públicas [gráficos 25 e 49]. Esta menção à 
transparência está mais presente entre os conselheiros que representam o poder público - o que, por um lado, pode indicar que estes têm mais conhecimento teórico de gestão pública e por isto sabem reconhecer que o conselho atribui transparência à gestão; ou, por outro lado, que esta transparência é demagógica e não chega, de fato, aos membros da sociedade civil.

Considera-se que a primeira destas hipóteses é mais plausível, pois, apenas pelo fato de o poder público se reunir mensalmente com a população, discutir assuntos públicos e fornecer os dados solicitados pelos conselheiros da sociedade civil com presteza - o que foi confirmado nas entrevistas - já é uma ampliação da transparência, se comparado ao modelo tradicional de gestão pública.

Outro fato que surpreende é que entre os conselhos, o que mais citou um ganho na transparência foi o $\mathrm{CMO}$, que, em outro ponto da entrevista, reclamou da falta de informações sobre os valores do orçamento com que trabalha [gráfico 49]. Wampler (2008) também aponta, com relação a administração anterior, a falta de transparência sobre os valores do orçamento em sua pesquisa. O outro conselho que lida diretamente com as demandas da população - o CRPPA - também mostra sentir falta de "prestação de contas" por parte da SPPA [gráfico 47]. Estas questões relacionadas à transparência do governo necessitam de decisões políticas para que se determine o que informar e como informar para atingir as diversas camadas da população, distanciando-se assim das formas de gestão tradicionais e autoritárias (SILVA; CRUZ; MELO, 2007). Segundo Satterthwaite (2005) um dos requisitos para a boa governança municipal é a transparência na gestão e no uso dos recursos públicos.

A política de orçamento participativo foi, sem dúvida, a mais citada entre os gestores de políticas públicas entrevistados. Isto se deve: ao fato deste ser o maior canal receptor de demandas da população do 
município; ao alinhamento à diretriz de Participação Cidadã; à longa história de existência do OP em Santo André; e também ao papel de "marketing " de cidades que ele representa na municipalidade.

Nas entrevistas com os gestores de políticas públicas das duas instituições que têm conselhos setoriais - o SDUH e o SEMASA -, o OP foi citado antes dos próprios conselhos, mostrando sua importância.

$\mathrm{Na}$ entrevista com a Secretaria de Desenvolvimento Urbano e Habitação, o CMPU recebeu um enfoque similar ao do OP, isto é, os dois conselhos parecem ter a mesma importância quando da formulação de políticas públicas da secretaria. Observa-se também nas entrevistas com os conselheiros, que os planos que estão sendo produzidos para detalhar 0 plano diretor - como, por exemplo, o Plano de Habitação - têm sido discutidos nas reuniões do CMPU.

Por outro lado, no Serviço Municipal de Saneamento Ambiental de Santo André (SEMASA), o COMUGESAN foi muito pouco valorizado como componente do sistema de gestão de políticas públicas daquela autarquia, pelos gestores entrevistados. Os elementos ressaltados na entrevista foram: o planejamento estratégico; as reuniões trimestrais de diretoria realizadas fora da instituição; e os indicadores estratégicos, que são utilizados juntamente com o Plano de Governo e com as demandas do OP para apoiar a tomada de decisão.

Frases retiradas das entrevistas permitem questionar se 0 COMUGESAN tem realmente dedicado a necessária atenção às questões relacionadas às políticas ambientais municipais: "Esse conselho [COMUGESAN] também define algumas diretrizes, algumas tomadas de decisões são submetidas neste conselho"; "[...] para eu fazer uma obra nem sempre preciso perguntar para o conselho se pode [...]"; "Todos os planos foram apresentados para eles [COMUGESAN], eles têm consciência de como 
o SEMASA funciona [...]"; e "[...] eles são muito demandados para uma tomada de decisões de algumas questões do licenciamento ambiental".

Durante a entrevista notou-se um desconforto quando foram levantados detalhes do processo de implementação das políticas públicas, pois foi necessário que houvesse um ajuste de vocabulário para que a entrevista com o gestor do SEMASA pudesse continuar. Houve também um conselheiro da sociedade civil no COMUGESAN, que, por participar de mais de um conselho, pôde afirmar comparativamente que "a gente tem, no fundo, recebido informes de ações que a administração tem preparado ou feito na cidade. Não tem sido um fórum de decisões". No Contexto "Papel do Conselho - $C+D^{\prime \prime}$ [gráfico 6] também fica evidente que, comparado com o CMPU, o COMUGESAN é menos citado como gestor de políticas públicas. Soma-se a isto o fato de os conselheiros da sociedade civil no COMUGESAN se sentirem com menos capacidade argumentativa nas reuniões [gráfico 38].

Ainda, com relação a estes conselhos, assuntos técnicoadministrativos ligados às políticas públicas, consomem muito tempo nas reuniões. O CMPU toma decisões sobre impacto de vizinhança e outorga onerosa. O COMUGESAN delibera sobre licenciamento ambiental e pedidos de perdão de multas relacionadas aos serviços de saneamento básico. Já afirma Teixeira (2000) que o exercício de funções importantes dos conselhos pode ser postergados pelo envolvimento com questões administrativas. No CMPU o problema foi detectado internamente e já foi corrigido, de modo que a câmara técnica - que já era a responsável por analisar os pedidos antes das reuniões - agora pode deliberar sobre estas questões. Mas, este problema ainda precisa ser resolvido no COMUGESAN.

A pesquisa mostrou que a representatividade aparece duas vezes nas respostas dos conselheiros.

A primeira menção à representatividade, e a mais significativa, aparece quando se questiona aos entrevistados sobre as 
atividades no conselho [gráfico 14]. Neste momento, a representatividade foi a atividade mais lembrada entre aquelas não burocráticas. $\mathrm{O}$ destaque aqui é dado para os membros da sociedade civil dos dois conselhos reivindicativos CMO e CRPPA - que têm uma auto-imagem de representantes da sociedade civil mais estabelecida.

A segunda vez em que a representatividade aparece nas entrevistas é quando se focalizam os problemas dentro dos conselhos [gráfico 31], mas, nesta ocasião, as questões sobre representatividade aparecem com pouca freqüência e em situações pontuais. Não fica clara a representatividade dos conselheiros da sociedade civil nos conselhos de políticas públicas - CMPU e COMUGESAN -, pois esta atividade não foi muito citada por seus membros. A representatividade nos conselhos torna-se ainda mais importante quando se verifica que, de maneira geral, as políticas públicas são divulgadas para a população, majoritariamente, através dos conselhos e das plenárias do orçamento participativo municipal.

Segundo as entrevistas, o papel que os conselhos deveriam ter de monitorar e fiscalizar a ação pública, não parece muito claro nos conselhos de Santo André [gráficos 15 e 26]. O CMPU, por exemplo, não tem esta atividade como atribuição na legislação que o regulamenta. Mesmo assim, a gestora de políticas públicas entrevistada afirmou que 0 monitoramento do andamento das políticas públicas é de competência do conselho e um dos membros da sociedade civil afirmou em entrevista, que o conselho tem este papel. Nesse sentido, apesar de em teoria ser este um dos papeis do conselho, não está regulamentado no CMPU, e, como conseqüência, é pouco mencionado nas entrevistas.

Com relação ao COMUGESAN, a lei que estabelece Política Municipal de Gestão e Saneamento Ambiental (SANTO ANDRÉ, 1998) atribui ao conselho a competência de "fiscalizar a correta aplicação dos recursos financeiros e a qualidade dos serviços prestados à população pelo SEMASA", 
mas isto não é reiterado em seu regimento interno. Esta pouca precisão aparece no CRPPA, cujo regimento diz apenas que os conselheiros podem "pedir vista de documentos" (SPPA, 2001?). O único dos quatro colegiados que apresenta clareza sobre este aspecto é o $\mathrm{CMO}$, que no Artigo $1^{\circ}$ de seu regimento diz:

O Conselho Municipal do Orçamento (CMO) é o instrumento de controle e planejamento das ações da Prefeitura, tendo por finalidade propor, fiscalizar e decidir sobre a utilização do Orçamento da Cidade. É um espaço de compartilhar poder e responsabilidades entre Prefeitura e População (SANTO ANDRÉ, 2008).

Este caráter vago do papel de fiscalizador da ação pública expresso por três conselhos fica claro nas entrevistas, uma vez que quase não é citado. O que causa estranheza é justamente não ter sido explicitado pelos membros do CMO, já que naquele regimento o papel fiscalizador é expresso com nitidez.

A população que participa da tomada de decisão normalmente se apropria do projeto, cuidando e fiscalizando (DOWBOR, 1993). Os conselhos têm a atribuição de formular, implementar e fiscalizar a ação pública, principalmente os membros da sociedade civil devem controlar o poder público, o que inclui a fiscalização e a cobrança pela transparência, assim como a participação na gestão e no planejamento (TEIXEIRA, 2000). Esta falta de solidez na atribuição de monitoramento da implementação de políticas públicas encontrada em Santo André enfraquece o potencial de alcançar a boa governança para o desenvolvimento sustentável (MONTEIRO, 2006).

Internamente à prefeitura parece não existir uma política unificada de monitoramento das políticas públicas. A Secretaria de Orçamento e Planejamento Participativo afirma que as políticas municipais são monitoradas tanto financeiramente quanto fisicamente por eles próprios, uma vez que é uma entidade que trabalha horizontalmente na prefeitura. $A$ 
SPPA afirma que um agente de planejamento realiza este acompanhamento apenas pelo cronograma financeiro. Já o SEMASA diz que o monitoramento é feito através de indicadores do programa de qualidade, que são indicadores de resultado, e não de ações, portanto, suas atuações são avaliadas pelos resultados. E a SDUH diz que este é um papel do conselho, como mencionado. Desse modo, pode-se concluir que não existe na PMSA uma política unificada de monitoramento das políticas públicas, mostrando uma fragilidade da gestão municipal.

Nos quatro conselhos trabalhados, as limitações nas possibilidades de ação decorrentes da falta de tempo e do acúmulo de trabalho foram ressaltadas, principalmente com relação aos conselheiros da sociedade civil [gráfico 29]. No contexto da SPPA este problema tem um agravante uma vez que existe a dificuldade de locomoção, dada pelo pouco transporte público e pelas grandes distâncias da região, polarizada pelo Parque Andreense e pela Vila de Paranapiacaba distantes um do outro aproximadamente $20 \mathrm{~km}$. Estas dificuldades materiais, associadas às diferenças de formação e informação entre os conselheiros das duas representações [gráficos 40 a 42] causam uma assimetria nas condições de participação, como apontado por Monteiro e Fleury (2006) e Teixeira (2000).

A PMSA, a SPPA e o SEMASA disponibilizam sempre que necessário, salas adequadas às reuniões do conselho e de suas câmaras técnicas, ao contrário de outras prefeituras, onde a infra-estrutura disponível é precária.

O CRPPA é o conselho que mais tem problemas de funcionamento. As grandes distâncias, o baixo grau de instrução dos membros da sociedade civil, as imprecisões de seu regulamento e as dificuldades de comunicação entre poder público e cidadãos estão na raiz destes problemas. Tanto os representantes do governo quanto os da população afirmam em entrevista [gráficos 39 e 40] que seus membros não 
estão suficientemente informados para participar do CRPPA. Neste caso, reuniões de conselho acabam não acontecendo por falta de quórum e desunião por parte dos conselheiros representantes da sociedade civil. Existe também um clima de tensão entre as duas representações, enfraquecendo o papel de ativador da democracia esperado dos conselhos [vide também gráfico 37].

Mesmo em uma única prefeitura, existem diversos níveis de funcionamento de conselhos municipais. Isto é expresso tanto pelos problemas apresentados pelo CRPPA, quanto pelas diferenças entre CMPU e COMUGESAN - dois conselhos a função de gerir políticas públicas apresentadas anteriormente. Isto, somado às diferenças de funcionamento dos conselhos entre as diversas municipalidades, reitera a afirmação de TONELLA (2006) quando diz que não é possível estabelecer ainda um padrão único de comportamento para os conselhos.

Com exceção do CRPPA, os conselheiros declararam que se sentem suficientemente informados para participar das reuniões de conselho [gráfico39], graças ao material que Ihes é enviado oficialmente e à busca de dados na prefeitura, na mídia ou em conversas com amigos realizadas por eles próprios [gráficos 43 e 46]. Mesmo tendo feito estas declarações, as entrevistas apontaram deficiências no processo informativo, como ressaltado nos resultados desta tese. Existe uma disparidade de condições entre os conselheiros das duas representações. Os membros do governo trabalham com a matéria do conselho em seu dia a dia, normalmente têm um grau de instrução mais elevado, conhecem os termos técnicos e o funcionamento da prefeitura, têm acesso a informações e apoio administrativo [gráficos 38 e 44]. Isto é um dos fatores que provoca uma assimetria de condições para participar do conselho, como afirma Teixeira (2000). Torna-se necessário ampliar o conhecimento dos membros da sociedade civil nos conselhos com uma visão ampla do município e do funcionamento da administração pública. Seria importante também que o governo apresentasse prestação de contas e 
informações técnicas relacionadas tanto à matéria do conselho quanto a assuntos em pauta. Isto ajudaria a incrementar o nível das discussões ocorridas nas reuniões. Estas informações poderiam chegar a eles tanto da forma como vem acontecendo - materiais oficiais produzidos para 0 funcionamento do conselho e busca individual por informações [gráficos 51 e 52] - quanto, e principalmente, através de capacitação específica, que só é realizada sistematicamente no CMO [gráficos 28, 38, 41 e 50]. Estes cursos precisam ser estruturados de forma a diminuir as diferenças de nível de formação existentes entre os conselheiros do poder público e da sociedade civil, que, muitas vezes, dificulta a comunicação em plenária .

Quando examina o CMO de Santo André, Wampler (2007) descortina que, embora o poder público e a sociedade civil tenham igualdade de votos, os representantes da prefeitura têm muito mais acesso à informação, mais entendimento e sabem usar melhor o poder político, além de serem mais unidos. A sociedade depende do governo para ter acesso à informação e o governo não produz uma informação relevante para tomada de decisão. Além disso, os membros da sociedade civil não têm a habilidade de argumentar com o governo. Atualmente, porém, os conselheiros da sociedade civil dizem que qualquer informação solicitada por eles a seus pares do poder público é trazida com presteza. Entretanto, observa-se que existe um desnível de formação persistente na maioria dos conselhos entre os representantes do governo e da sociedade civil organizada e isto, embora não seja desejado, decorre naturalmente das lideranças e dos representantes escolhidos. Embora sem solução, este aspecto pode ser minimizado com uma capacitação mais abrangente.

Nos resultados apresentados pela pesquisa, principalmente entre as respostas dadas à Questão $15^{62}$ [gráficos 35, 36, 37 e 38] das entrevistas com os conselheiros, fica claro que, os representantes do

62 Questão 15 - Na sua opinião existe diferença de atuação entre os conselheiros que são funcionários público e os da sociedade civil? 
governo nos conselhos exercem a sua representação de acordo com o interesse do poder público, muitas vezes independente de suas convicções. Os próprios conselheiros do governo expressam haver reuniões de alinhamento de conduta e a tendência é acompanhar a orientação dada. Os membros da sociedade civil mencionam este comportamento em bloco do poder público com menos freqüência. Por um lado, esta atitude de alinhamento com os interesses de uma instituição é esperada daqueles que a representam, mas por outro, em um contexto de paridade, onde metade da bancada representa uma única instituição e a outra parte é diversificada, o colegiado pode vir a ter um papel exclusivamente de legitimação das questões apresentadas. Esta postura do poder público não coincide com os achados de Tonella (2006) em que, nos conselhos estudados pela autora, os representantes do poder público não se comportam como porta-vozes do primeiro escalão.

Gohn (2007a) aponta que a paridade é uma das questões cruciais para os conselhos gestores, pois não existem critérios que assegurem a igualdade de condições quanto ao acesso à informação ou disponibilidade de tempo, entre as duas representações.

Wampler (2007) notou alguns aspectos deficientes no CMO de Santo André que já foram solucionados, como, por exemplo, o volume de demandas aprovadas pelo conselho que foram efetivamente realizadas ${ }^{63}, 0$ que reitera a expectativa de que os conselhos tendem a corrigir rumos em aspectos de seu funcionamento, e que a "fórmula ideal" está em construção. É necessário, porém cuidado para que estes colegiados não sejam espaços de legitimação de decisões tomadas, como acontecia nos anos 1980, onde em alguns casos de participação popular os processos eram "arquitetados de cima para baixo, objetivando legitimar um pseudo-processo democrático em

\footnotetext{
${ }^{63}$ Ver nos resultados desta pesquisa.
} 
curso" (GOHN, 2007a, p.54). Na pesquisa de Wampler (2007) ${ }^{64}$, a paridade do CMO permitiu que, na prática, o governo dominasse as decisões, podendo bloquear a agenda; afinal, os conselheiros trabalham sob as regras do governo. Este autor coloca que o empoderamento e aprendizado público desconectados com a real delegação de autoridade são, na verdade, conceitos ocos. Nota-se que no formato atual dos conselhos é difícil para os conselheiros da sociedade civil barrar as propostas do governo. As entidades representadas são diversas, com interesses diversos e caso os membros do poder público atuem em uníssono, há necessidade de unanimidade para que a sociedade civil empate uma disputa em plenária. Como agravante tem-se 0 fato de que os membros do poder público se reúnem e se preparam para as reuniões, enquanto questões como limitações de tempo, local, diversidade de interesses, escolaridade e até de mobilização tornam inviável que esta organização aconteça por parte da sociedade civil. Os conselhos seriam então instrumentos onde as decisões do governo seriam legitimadas pela população.

Kjaer (2004) expõe que a legitimidade do governo deve ser instituída através do resultado da associação de duas formas de legitimação, que podem pender mais para um lado ou para o outro, como segue: orientada pela "entrada" ou orientada pela "saída" ${ }^{25}$. Quando orientada pela "entrada" a legitimidade se estabelece através de procedimentos democráticos aceitos pela maioria e decorre de acordos entre os que devem obedecer as regras, no caso os cidadãos através de suas representações. Por outro lado, quando orientada pela "saída", a legitimidade deriva da efetividade das políticas, dos resultados alcançados para o bem comum. Existe então, baseado na legitimidade orientada pela entrada, a necessidade de que os representantes da sociedade civil

\footnotetext{
${ }^{64}$ É importante relembrar que a pesquisa desenvolvida por Wampler (2007 e 2008) teve foco apenas nos processos de Orçamento Participativo.

65 No original diz-se "imput-oriented" e "output-oriented".
} 
concordem com as decisões, mas eles não demonstraram perceber a dificuldade em barrar as propostas do governo trazidas para a deliberação nos conselhos.

Vale lembrar aqui as duas formas para saber quem exerce 0 poder apresentadas por Fulks e Perissinotto (2006, p.68): o "método posicional" e o "método decisional". O primeiro está relacionado a posições estratégicas ocupadas pelos indivíduos em uma comunidade, o que coloca todos os membros de um conselho deliberativo em situação de poder. 0 segundo associa-se ao "indivíduo ou grupo que, num processo decisório específico e conflituoso, [consiga] fazer com que suas preferências [prevaleçam] sobre as preferências dos demais". Assim, o empoderamento da sociedade civil fica fragilizado pelo alinhamento de conduta expresso pelo poder público, associado à assimetria de condições para a participação verificada.

A participação digna necessita de um certo grau de politização, um envolvimento sério dos participantes, o reconhecimento da dignidade de todos e procedimentos que garantam que tanto a participação em si, quanto seus resultados sejam reais e eficazes (BÜHLER, 2002). 0 trabalho de Bühler é bastante crítico da participação, e, para o autor, existe uma ênfase exagerada em fórmulas e técnicas e as dinâmicas de participação nas instâncias formais são negligenciadas (BÜHLER, 2002). Monteiro e Fleury (2006) também levantam esta questão quando afirmam que uma das principais metas é tornar a participação nos conselhos igualitária na tomada de decisão. Por fim, Gohn (2004, p.22) alerta para o perigo de os conselhos serem instrumentos para responsabilizar os cidadãos, "via parcerias nas políticas sociais governamentais".

Como afirma Jacobi (2002), os governos locais devem estar pré-dispostos a criar espaços que sejam base da legitimidade, para que a população participe tornando os conflitos visíveis. Mas é necessário, por 
outro lado, que a população continue com seus grupos de pressão ativos para que o Estado mantenha a real deliberação de poder (BAVA, 2005)

Portanto é necessário que o poder público diminua a pressão que seus representados expressam receber; mas também é preciso que os representantes da sociedade civil organizada estabeleçam redes de comunicação e se fortaleçam pressionando o poder público quando necessário, ocupando, assim, mais espaço na esfera pública. 


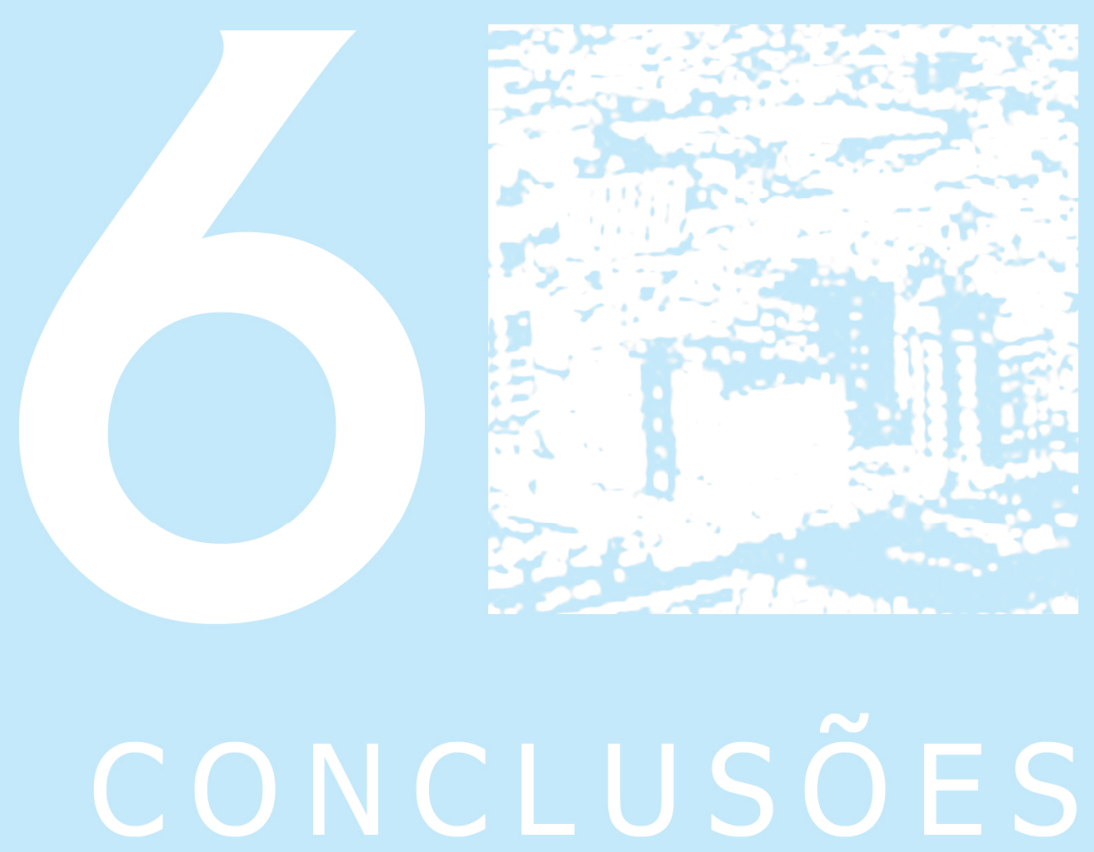



\section{CONCLUSÕES}

Os estudos aqui realizados buscaram verificar se os conselhos municipais de Santo André cumprem seu papel de incluir os atores sociais na tomada de decisão nos assuntos relacionados às políticas públicas municipais, principalmente àquelas ligadas à promoção do desenvolvimento urbano sustentável: a política urbana; a política ambiental; o orçamento participativo, que é o fórum mais expressivo de recepção das demandas da população e de priorização destas demandas por parte dos cidadãos; e o conselho que busca estabelecer diálogo e poder de deliberação com os habitantes da Área de Proteção e Recuperação dos Mananciais. Assim, a pesquisa aqui realizada teve como objetivo analisar o funcionamento de conselhos municipais de Santo André, visando identificar progressos e fragilidades para propor ajustes e melhorias.

Para tanto, foi construído referencial teórico que deu suporte à análise e interpretação dos dados levantados em campo (capítulo 3); o município de Santo André foi caracterizado tanto do ponto de vista do território e sua ocupação, quanto dos processos de gestão participativa que vem construindo (item 4.1); o processo de gestão de políticas públicas em Santo André foi descrito e discutido a partir das entrevistas com os gestores (item 4.2); e o funcionamento dos conselhos foi analisado e discutido por meio de entrevistas cedidas pelos conselheiros (itens 4.3 e 4.4).

Santo André é um município que se caracteriza por atender as demandas dos cidadãos abrindo espaço para a participação do conjunto da sociedade. Esta abertura decorre do tipo de governo que propõe o diálogo, antecipando-se à legislação, seja por meio do envolvimento direto da população, seja por meio de representações sociais nas instâncias de decisão. Esta pesquisa só pôde analisar a gestão municipal através destes quatro conselhos estudados dada a abertura por parte da prefeitura, que, 
desta forma, se expõe a criticas. Sem esta predisposição, Santo André não teria participado de premiações e realizado convênios para pesquisa com universidades. Isto mostra que o município realmente se posiciona na busca de melhoria contínua de seus processos participativos.

Tem havido evolução dos processos de participação cidadã em Santo André. Os projetos participativos do município não são estáticos e acompanham a dinâmica local. Isto pode ser visto no Projeto Cidade Futuro que foi se adaptando às recentes colocações da ONU e no OP que evoluiu de consultivo a participativo e que revê seu regimento a cada ciclo de dois anos. Sabe-se que a continuidade política pela qual o município vinha passando contribuiu para isto.

Os conselhos municipais de Santo André têm funcionamento pautado no regimento que é realmente cumprido, garantindo-se as reuniões, a paridade, as discussões e a busca por consensos. Isto acontece mesmo nos conselhos que não são regulamentados por lei. Desta forma, observouse que as práticas clientelistas perderam espaço no município e que, através das escolhas da população no orçamento participativo tem-se promovido a eqüidade. A transparência, por outro lado, não é muito citada nas entrevistas, principalmente pelos membros da sociedade civil, mas estes membros afirmam que todas as informações que pedem para seus pares do poder público são atendidas com presteza. Assim, parece que a prefeitura de Santo André poderia ser mais ativa na divulgação de informações para seus conselheiros e para a sociedade civil como um todo. Um problema de falta de transparência está relacionado ao montante de recursos financeiros gerido pelo CMO, que não é divulgado.

Dos quatro conselhos estudados, o CMO é o mais citado, tanto pelos gestores municipais quando enumeram os parâmetros para a definição de políticas públicas, quanto pelos autores citados neste estudo, cabe mencionar que o CMO de Santo André foi inclusive caso de análise 
internacional. Ao contrário dos conselhos, que muitos são criados por exigência legal e até para repasse de verbas de outras instâncias de governo, o orçamento participativo é um processo voluntário dos municípios e muito valorizado como canal de diálogo e de deliberação mais ampla incluindo a população. Sua criação e divulgação tem valor para a democracia deliberativa, mas também está associada ao "marketing" de cidades.

O CRPPA, conselho também relacionado com o diálogo direto com a população e recepção de demandas, tem alguns problemas internos decorrentes, em parte, de seu regimento impreciso, e, em parte, por problemas de diálogo entre os membros do poder público e da sociedade civil, e ainda, de logística, como por exemplo, de transporte. A capacitação tornou-se imprescindível para que este conselho possa trabalhar na construção de consensos e objetivos comuns. As mencionadas disparidades de condições para a participação nos conselhos entre os membros do poder público e da sociedade civil tornam-se evidentes neste conselho. 0 regimento interno impreciso é um dos responsáveis por esta situação, mas os representantes do governo precisam estar preparados para dialogar com a população através de seus representantes no conselho, e, por sua vez, a sociedade civil organizada precisa ser capacitada para compreender 0 objetivo do conselho, seu funcionamento, as restrições ambientais a que estão submetidos por se localizar em área de proteção de mananciais e ter uma visão mais ampla do município e da estrutura do governo. A experiência com a revisão sistemática do regimento interno e o processo de capacitação que ocorrem no CMO deveriam ser aproveitadas no CRPPA.

Os dois conselhos diretamente relacionados com a gestão das políticas públicas municipais enfrentam problemas com o excesso de deliberações sobre assuntos administrativos nas reuniões, deixando pouco espaço para a discussão de políticas públicas acontecerem. O CMPU vem se mostrando o conselho mais ativo e recentemente solucionou este problema, permitindo que as câmaras técnicas, que já faziam a analise prévia dos 
pedidos de licenciamento, passassem a deliberar sobre eles, o que libera tempo de reunião para discutir as políticas e os planos, programas e projetos. O COMUGESAN tem menos participação nas deliberações sobre políticas públicas. Isto foi expresso tanto na entrevista com os gestores do SEMASA, quanto nas entrevistas com os conselheiros. Novamente tem-se que a experiência do CMPU deveria ser aproveitada no COMUGESAN para torná-lo um conselho mais direcionado à gestão das políticas públicas do município.

Existe integração entre os quatro conselhos estudados, mas ainda persiste uma desconexão entre o CMPU e o CRPPA. Isto pode ser melhorado com o fortalecimento do CRPPA, abrindo-se uma cadeira para um representante do CRPPA no CMPU ou vice versa. Afinal, mesmo assegurando-se a integração entre as políticas urbana e ambiental, assim como as necessidades da população expressas parcialmente nas demandas do OP, se a política urbana e a gestão da área de mananciais do município não estiverem integradas, a possibilidade de uma política geral de desenvolvimento urbano sustentável fica enfraquecida. Além disto, Santo André utiliza os conselhos e as plenárias do orçamento participativo como os principais canais de divulgação das políticas públicas, o que torna esta integração dos conselhos ainda mais importante.

O poder público precisa criar formas de integração entre os conselhos, tanto para que as diversas políticas setoriais se integraem, quanto para que os ganhos de qualidade na atuação dos conselhos sejam disseminados nos diversos fóruns municipais. Para que isto ocorra é necessário que o município crie um evento periódico com os conselheiros expondo as principais políticas em andamento, os avanços e as dificuldades encontradas. Ou mesmo trazendo palestrantes com as inovações de outros municípios, ou ainda de outros países, estimulando o debate. 
Um problema a ser enfrentado é o papel de monitorar e fiscalizar a ação pública que não é claramente atribuído aos conselhos, e os conselheiros, como conseqüência não assumem esta atribuição. Isto se agrava quando se constata que o governo andreense não apresenta uma política unificada de monitoramento das políticas públicas.

Outro desafio é a disparidade de condições para participar entre os membros do poder público e da sociedade civil que está presente de forma generalizada nos conselhos brasileiros, e também em Santo André. Os membros do governo muitas vezes trabalham com a matéria em questão no conselho, os da sociedade civil não necessariamente trabalham diretamente com o assunto. Novamente os conselheiros do poder público têm grau de instrução relacionado ao seu cargo e a sua atuação no conselho, sendo que os demais conselheiros não necessariamente têm a escolaridade e, muito menos, o conhecimento técnico equivalente ao dos seus colegas. Por outro lado, os conselheiros da sociedade civil têm o conhecimento do "lócus" ou da prática profissional de mercado que os conselheiros do poder público dificilmente têm. Assim, este entrave precisa ser minimizado, principalmente através de capacitação adequada, para que existam condições horizontais de relacionamento e a ação comunicativa possa acontecer.

Cabe ao poder público dar condições adequadas ao funcionamento dos conselhos. Isto implica na necessidade de oferecer local de apoio onde ficam disponíveis materiais físicos e eletrônicos trazidos tanto pelo poder público quanto pela sociedade civil. A ausência destes espaços dificulta a atuação dos conselheiros, uma vez que estes têm restrições de tempo para a participação. Outra forma de preparar os conselheiros da sociedade civil para atuar é elegê-los com no mínimo seis meses de antecedência da data da posse, sendo que neste período ele deverá participar das reuniões de conselho como ouvinte e participar de capacitação, preferencialmente junto a universidades de referência. Assim, o representante da sociedade civil chegará em plenária conhecendo o 
funcionamento do conselho e do governo municipal, o significado democrático da existência do conselho, o que significa sua representatividade, tendo uma visão abrangente do município, a política de governo e as principais políticas públicas de cada área, assim como conceitos chave que fazem parte da matéria do conselho em que atua. Esta capacitação deve focar também as deficiências encontradas, como, por exemplo, as relacionadas com o papel de fiscalizador da ação pública que é do conselheiro e que se apresenta frágil em Santo André. Para manter a experiência da maioria, a renovação dos conselheiros deve se pelo terço, com exceção do CMO, por exemplo, que tem ciclos de funcionamento. Por fim, o regimento deve ser revisto regularmente para que se efetive um processo de melhoria contínua de seu funcionamento. Desta forma tem-se o fortalecimento dos representantes da sociedade civil.

A paridade numérica nos conselhos é um avanço em termos de democracia neste país e deve ser valorizada como tal. É necessário que haja diversidade de participantes no conselho promovendo a discussão e a ampliação dos pontos de vista para a produção do entendimento e mesmo do consenso. Com a paridade, já instituída, tem-se metade dos membros do poder público representando uma única instituição, o governo, e muitas vezes votando de acordo com os interesses de seu representado, e metade, membros da sociedade civil organizada, representando instituições diversas com interesse diversos, e também votando de acordo com os interesses de seus representados. Assim, quando não acontece o consenso em plenária e determinada matéria vai para votação, as possibilidades reais de a sociedade civil barrar a proposta do poder público, de acordo com as declarações dos conselheiros, ficam extremamente reduzidas. Desta forma, a bancada da sociedade civil, que é diversificada em seus interesses terá que se organizar previamente e unir-se em torno de um interesse único para empatar uma disputa, o que é difícil, devido as mencionadas disparidades de condições. 
Assim sendo, torna-se ainda mais evidente a necessidade do fortalecimento dos representantes da sociedade civil para participar do conselho. O engajamento do governo andreense em abrir canais de participação é essencial para que o empoderamento da sociedade civil aconteça, mas a responsabilidade de pressionar o governo e tomar uma posição ainda é da sociedade civil. A descrita capacitação tem papel essencial no aprendizado para a democracia, e não se pode relevar os problemas brasileiros com a educação de base que não conduz objetivamente à cidadania, mas pode aperfeiçoá-la. Observa-se que, mesmo os conselheiros ocupando uma posição de poder, não necessariamente exercem este poder plenamente. Com esta fragilidade, os conselhos se apresentam então como instrumentos onde as decisões seriam legitimadas pela população, que não demonstra perceber que seu poder decisório está enfraquecido. Se o exercício de poder não for pleno, o empoderamento e o aprendizado público se esvaziam de significado e a democracia deliberativa não acontece. Os governos deste século XXI devem estar predispostos a compartilhar plenamente a tomada de decisão, o que exige a correção destes entraves e que o empoderamento seja exercido em todo seu potencial através dos conselhos municipais. Somando-se à necessária capacitação pode-se estabelecer nos regimentos dos conselhos um mandato para os representantes do governo, de forma que estes se sintam mais livres para votar de acordo com seus ideais, mesmo que isto implique às vezes, em discordar da orientação recebida.

Santo André é um município com duas décadas de experiência em gestão participativa, tendo conquistas importantes e projetos premiados por organizações nacionais e internacionais, sendo considerado um caso de sucesso. Ficou evidenciado que existem fragilidades importantes no funcionamento dos conselhos, como as acima indicadas, que precisam ser superadas através do melhor aparelhamento dos conselhos, para ampliar o compartilhamento de poder entre governo e sociedade civil, confirmando-se 
a hipótese deste trabalho de que "o processo de tomada de decisão nos conselhos municipais, apesar de apresentar progressos importantes, apresenta fragilidades, mesmo em municípios que incorporam e estimulam a democracia deliberativa a partir da Constituição Federal de 1988".

Dada a proliferação dos conselhos e a pré-disposição de Santo André em manter canais de gestão compartilhada é muito provável que os problemas enfrentados neste município também ocorram em outras cidades brasileiras. Assim, tanto os avanços nos trabalhos dos conselhos andreenses, quanto os problemas enfrentados podem, mais uma vez, servir de exemplo para outros municípios. O estudo permitiu, portanto, estabelecer relações entre a teoria e a prática em questões relativas ao funcionamento de conselhos, oferecendo elementos para a reflexão e decisão quanto aos sistemas de gestão municipal e suas conexões com princípios de governança. 


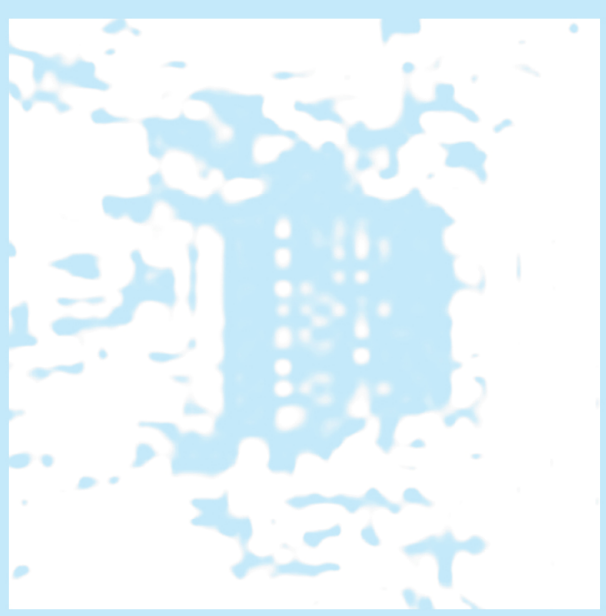

REFERENCIAS 



\section{REFERÊNCIAS}

ACSELRAD, Henri. A duração das cidades: sustentabilidade e risco nas políticas urbanas. Rio de Janeiro: Lamparina, 2009.

ALVA, Eduardo Neira. Metrópoles (In)sustentáveis. Rio de Janeiro: Relume Dumará, 1997.

ALVIM, Angélica A; Tanus Benatti. Desafios das Políticas Urbanas no Brasil: a importância dos instrumentos de avaliação e controle social. Cadernos de Pós-Graduação em Arquitetura e Urbanismo. p. 1-24, 2007.

ANASTASIA, Fátima; AZEVEDO, Sérgio. Governança, "Accountability" e Responsividade. Revista de Economia Política, v. 22, n. 1, p. 85, jan.mar. 2002.

ASSIS, Marcelo Prudente. Funcionamento do Conselho Municipal de Política Urbana [CMPU]. In: Relatório de pesquisa, parte integrante do projeto MEGA - Avaliação Estratégica do Processo de Implementação das Políticas de Desenvolvimento e Meio Ambiente no Município de Santo André - SP. 2009.

ASSIS, Marcelo Prudente; VENDRAMINI, Paula R. Jorge. Funcionamento do Conselho Municipal de Orçamento [CMO]. In: Relatório de pesquisa, parte integrante do projeto MEGA - Avaliação Estratégica do Processo de Implementação das Políticas de Desenvolvimento e Meio Ambiente no Município de Santo André - SP. 2009.

ASSIS, Marluce Maria Araújo; VILLA, Tereza Cristina Scatena. Um processo em construção. Revista Latino-am Enfermagem, v. 11 n. 3, p.376-382, mai.-jun. 2003.

AVRITZER, Leonardo. $\mathbf{O}$ orçamento Participativo: As experiências de porto alegre e Belo Horizonte. DAGNINO, Evelina (Org.). Sociedade civil espaços públicos no Brasil. São Paulo: Paz e Terra, 2002.

AVRITZER, Leonardo; PEREIRA, Maria de Lourdes Dolabela. Democracia, participação e instituições híbridas. Teoria e Sociedade, Número especial, p. 14-39, mar. 2005. 
BALCÃO, Nilde; TEIXEIRA, Ana Claudia (org.). Controle social do orçamento público. Revistas Pólis, São Paulo, n. 44, nov. 2003.

BAUMAN, Zygmunt. Globalização: as conseqüências humanas. Rio de Janeiro: Jorge Zahar, 1999

BAVA, Silvio Caccia. Democracia e Participação. in: TEIXEIRA, Ana Claudia Chaves, (Org.). Os sentidos da democracia e da participação. São Paulo: Instituto, Pólis, 2005.

BESSERMAN, Sergio. Indicadores. In: TRIGUEIRO, André (org). Meio ambiente no século 21. Rio de janeiro, Sextante, 2003. p. 91-106.

BEZERRA, Maria do Carmo de Lima; FERNANDES, Marlene Allan (coordenação). Cidades Sustentáveis: subsídios à elaboração da Agenda 21 Brasileira. Brasília: Ministério do Meio Ambiente. Instituto Brasileiro do Meio Ambiente e dos Recursos Naturais Renováveis; Consórcio Parceria 21 IBAM - ISER - REDEH, 2000.

BONFIM, Washington Luís de Sousa; SILVA Irismar Nascimento. Instituições políticas, cidadania e participação: a mudança social ainda é possível?

Revista Sociol. Polít., Curitiba, v. 21, p.109-123, nov. 2003.

BOSCHI, Renato Raul. Descentralização, Clientelismo e Capital Social na Governança Urbana: Comparando Belo Horizonte e Salvador. Dados, Rio de Janeiro, v.42, n.4, 1999.

BOSSEL, Hartmut. Indicators for Sustainable Development: Theory, Method, Applications. Winnipeg: IISD, 1999.

BOURDIN, Alain. A questão local. Rio de Janeiro: DP\&A, 2001.

BOURDIN, Alain. Gouvernance, appartenances sociales et gestion dês services urbains. Les Annales de la Recherche Urbaine, Paris, n. 80-81, p. 181-187, dez. 1998.

BOVAIRD, Tony, and LOFFLER Loffler. Evaluating the Quality of Public Governance: Indicators, Models and Methodologies. International Review of Administrative Sciences. v. 69, n. 3, p. 313-328, 2003. 
BOVAIRD, Tony. Public governance: balancing stakeholder power in a network society. International Review of Administrative Sciences, v.71, n. 2, p. 217-226, 2005. DOI: 10.1177/0020852305053881

BRASIL. Constituição (1988). Constituição da República Federativa do Brasil. Brasília, DF: Senado, 1988.

BRASIL. Lei $\mathrm{n}^{\circ} 10.257$ de 10 de julho de 2001. Regulamenta os arts. $182 \mathrm{e}$ 183 da Constituição Federal, estabelece diretrizes gerais da política urbana e dá outras providências. Disponível em:

<http://www.planalto.gov.br/ccivil/leis/LEIS_2001/L10257.htm>. Acesso em: 4 de março de 2010.

BRESSER-PEREIRA, L. C. O modelo estrutural de governança pública. RERE - Revista Eletrônica sobre a Reforma do Estado, Salvador, 2007. Disponível em: <http://www.direitodo estado.com/revista/RERE-10-JUNHO2007-BRESSER\%20PEEREIRA.pdf>.

BRUNA, Gilda C. et al. Estruturação Urbana e Arranjos Produtivos Locais: identificação e análise das relações entre processos sociais, efeitos espaciais e políticas urbanas através de estudo dos casos das cidades de Franca e Limeira no estado de São Paulo. Relatório de Pesquisa. São Paulo, MackPesquisa (Mimeo), 2006.

BRUNDTLAND, Gro Harlem (cood.); Comissão Mundial sobre Meio Ambiente e Desenvolvimento. Nosso Futuro Comum. Rio de Janeiro: Fundação Getúlio Vargas, 1991.

BÜHLER, U. Participation 'with justice and dignity': Beyond 'the new tyranny'. Peace, conflict and development. An interdisciplinary journal, v.1, n. 1, p. $1-16,2002$

BURTON, Paul. Conceptual, Theoretical and Practical Issues in Measuring the Benefits of Public Participation. Evaluation, v. 15, n. 3, p. 263-284, july 2009. DOI: $10.1177 / 1356389009105881$

CAETANO, João Ricardo Guimarães. Políticas públicas municipais de gestão ambiental e estratégias de ação em áreas sob proteção ambiental: o caso de Santo André - SP. 2006. Dissertação (Mestrado em engenharia urbana) - Universidade Federal de São Carlos, São Carlos, 2006. 
CALDERÓN, Adolfo Ignácio; MARIM, Vlademir. Educação e políticas públicas: os conselhos municipais em questão. Teias: Rio de Janeiro, ano 3, n. 6, jul/dez 2002.

CAMARGO. Aspásia. Governança In: TRIGUEIRO, André (org). Meio ambiente no século 21. Rio de janeiro, Sextante, 2003. p. 307-322.

CARPIM, Thais Regina Pavez. Políticas públicas e ampliação de capital social em comunidades segregadas: o programa Santo André Mais Igual. 2005. Dissertação (Mestrado em Ciência Política) - FFLCH Universidade de São Paulo, São Paulo, 2005.

CARSON, Rachel. Primavera Silenciosa. São Paulo: Melhoramentos, 1964. CASTELLS, Manuel. A sociedade em rede. São Paulo: Paz e Terra, 2003.

CEZARE Juliana Pellegrini. CRPPA. In: Relatório de pesquisa, parte integrante do projeto MEGA - Avaliação Estratégica do Processo de Implementação das Políticas de Desenvolvimento e Meio Ambiente no Município de Santo André SP. 2009b.

CHEVALIER, Dominique. La politique urbaine domaine réservé du maire. Les Annales de la Recherche Urbaine, Paris, n. 80-81, p. 121-127, dez. 1998.

CIDADES HISTÓRICAS BRASILEIRAS. Disponível em: < http://www.cidadeshistoricas.art.br/paranapiacaba/pnphisp.php> Acesso em: jan.2010.

CKAGNAZAROFF, Ivan Beck. Reflexões sobre estratégias de governança local. Gestão e Sociedade. v. 3, n. 5, p. 23-47, jan/jun 2009.

COSTA, Heloisa. Desenvolvimento Urbano Sustentável: uma contradição de termos? R. B. Estudos Urbanos e Regionais. n. 2, p. 55-71, nov. 1999.

DAGNINO, Evelina. Sociedade civil e espaços públicos no Brasil. In: DAGNINO, Evelina (Org.). Sociedade civil espaços públicos no Brasil. São Paulo: Paz e Terra, 2002. p. 9-16.

DANIEL, Celso. Conselhos, esfera pública e co-gestão. In: CARVALHO, Maria do Carmo; TEIXEIRA, Ana Claudia (Org.). Conselhos gestores de políticas públicas. São Paulo: Pólis, 2000. p. 123-133. 
DOWBOR, Ladislau. Descentralização e meio ambiente. IBAMA, 2003.

Disponível em:

<http://www.aprece.org.br/site/downloads/TextoLadislauDowbor913911648 10399.doc>. Acesso em: out. 2008.

EATY, Daniel; IVANOVA, Maria. Governança Ambiental Global. São Paulo: SENAC, 2005.

FARIA, Carlos Aurélio Pimenta. Idéias, conhecimento e políticas públicas: um inventário sucinto das principais vertentes analíticas recentes. Revista

Brasileira de Ciências Sociais, v. 18, n. 51, p. 21-29, fev. 2003.

FERNANDES, Marlene. Agenda Habitat para Municípios. Rio de Janeiro: IBAM, 2003

FERREIRA, João Sette Whitaker. São Paulo: o mito da cidade-global. Tese de Doutorado. Faculdade de Arquitetura e Urbanismo da Universidade de São Paulo. São Paulo: FAUUSP, 2003.

FOLADORI, Guillermo. Sustentabilidad ambiental y contradicciones sociales. Ambiente \& Sociedade, ano 2, n. 5, 20 Semestre de 1999.

FREY, Klaus. A dimensão político-democrática nas teorias de desenvolvimento sustentável e suas implicações para a gestão local.

Ambiente \& Sociedade, Ano 4, n. 9, 2 semestre de 2001.

FREY, Klaus. Development, good governance, and local democracy.

Brazilian Political Science Review [Online]. Rio de Janeiro, v.2, n.2, p. 39-73, july-dec. 2008. Disponível em: < http://socialsciences.scielo.org/scielo.php?pid=S1981-

38212008000100007\&script=sciarttext\&tlng=es >. Acesso em: dez. 2009.

FREY, Klaus. Governança Urbana e Participação Pública. RAC-Eletrônica, v. 1, n. 1, p. 136-150, jan.-abr. 2007. Disponível em < http://www.anpad.org.br/rac-e >. Acesso em 2008.

FREY, Klaus. Políticas públicas: um debate conceitual e reflexões referentes à prática da análise de políticas públicas no Brasil. Planejamento e políticas públicas, n. 21, p. 211-259, jun. 2000. 
FULKS, Mario; PERISSINOTTO, Renato. Recursos, decisão e poder: conselhos gestores de políticas públicas de Curitiba. Revista Brasileira de Ciências Sociais, v. 21, n. 60, p. 67-81, fev. 2006.

GAUTHIER, Mario. La planification des transports et le développement durable à Montreal : quelles procédures de débat public pour quelles solutions intégrées ? Flux n. 60/61, p. 50-63, abr.-set. 2005.

GAVENTA, John. Em direção a uma Governança Local Participativa: Seis Propostas para a Discussão. Brighton, UK: LogoLink, 2001. Disponível em: <www.ids.ac.uk/logolink/>. Acesso em: jun. 2008.

GERRA, Isabel Carvalho. Participação e acção coletiva: interesses, conflitos e consensos. Estoril: Princípia, 2006.

GIL, Antonio Carlos. Métodos e técnicas de pesquisa social. São Paulo: Atlas, 1999.

GOHN, Maria da Glória. Conselhos Gestores e participação

sociopolítica. São Paulo: Cortez, 2007a.

GOHN, Maria da Glória. Empoderamento e participação da comunidade em políticas sociais. Saúde e Sociedade, v.13, n.2, p. 20-31, mai.-ago. 2004.

GOHN, Maria da Glória. Movimentos sociais no início do século XXI: antigos e novos atores sociais. Petrópolis, RJ: Vozes, 2007b.

GRAGNANI, Renato. 0 processo do orçamento participativo de Santo André. 2007. Dissertação (Mestrado em Administração) - Universidade municipal de São Caetano do Sul, São Caetano do Sul, 2007.

HABERMAS, Jürgen. Direito e democracia: entre a facticidade e a validade. Volume II. Rio de Janeiro, Tempo Brasileiro, 2003.

HABERMAS, Jürgen. Técnica e ciência como "ideologia". Lisboa: Edições 70, 2009.

HADDAD, Sergio. Diálogo e controvérsia entre governo e sociedade civil. in: TEIXEIRA, Ana Claudia Chaves, (Org.). Os sentidos da democracia e da participação. São Paulo: Instituto, Pólis, 2005. p. 91-117.

HARVEY, David. Condição pós-moderna. São Paulo: Loyola, 2004. 
IVO, Anete Brito Leal. Governabilidade e governança na América Latina : teses e paradoxos. VII Congreso Internacional del CLAD, Lisboa, Portugal, 8-11 Oct. 2002.

JACOBI, Pedro R.. Políticas sociais locais e os desafios da participação citadina. Ciência \& Saúde Coletiva, v. 7, n. 3, p. 443-454, 2002.

KISSLER, Leo; HEIDEMANN, Francisco G.. Governança pública: novo modelo regulatório para as relações entre Estado, mercado e sociedade? RAP Rio de Janeiro v. 40, n. 3, p. 479-99, mai.-jun. 2006.

KJAER, Anne Mette. Governance. Cambridge: Polity Press, 2004.

LATENDRESSE, Anne. Porto Alegre: La nouvelle gouvernance urbaine. 2004. Revista de debates do Contro de Acessoria e Estudos Urbanos Cidade. Ano 1, n. 1, dez. 2008. Disponível em: <www.ongcidade.org/rev>. Acesso em: dez.2009.

LEE, Kai N. Urban sustainability and the limits of classical environmentalism. Environment \& Urbanization. V. 18 n.1, p. 9-22. Abr. 2006. DOI:10.1177/0956247806063940

LEFÈVRE, Ana Maria Cavalcanti, LEFRÈVE, Fernando. 0 discurso do sujeito coletivo. Um novo enfoque em pesquisa qualitativa. Desdobramentos Caxias do Sul: EDUCS, 2003.

LEPAGE, Martine. Um Exercice démagogique. Jornal La PResse, Montreal, Canadá, p. A26, 18 jun. 2008.

LEVY, Evelyn. Democracia nas cidades globais: um estudo sobre Londres e São Paulo. São Paulo: Nobel, 1997.

LÜCHMANN, Lígia Helena Hahn. A representação no interior das experiências de participação. Lua Nova, São Paulo, v. 70 p. 139-170, 2007

MAGNAGHI, Alberto. Territorial Heritage: a genetic code for sustainable development. In: International Network for Urban Research and Action (INURA). Possible Urban Worlds: urban strategies at the end 20th century. Zurich: Birkhäuser Verlag, 1998. 
MARICATO, Ermínia. As idéias fora do lugar e o lugar das idéias: Planejamento urbano no Brasil. In: ARANTES, Otília; VAINER, Carlos; MARICATO, Ermínia. A cidade do pensamento único: desmanchado consensos. Petrópolis, RJ: Vozes, 2000.

MARQUES, Juliana Di C. M. Territórios da Indústria Revisitados: a trajetória da atividade industrial no Município de São Paulo. Tese de Doutorado. Faculdade de Arquitetura e Urbanismo da Universidade de São Paulo. São Paulo, FAUUSP, 2010.

MASSUTTI, Emeri Angela. Gestão participativa e urbanização: de favela para o bairro Capuava em Santo André, SP. 2007. Dissertação (Mestrado em Urbanismo) - PUC-Campinas, Campinas, 2006.

MEADOWS, Donella H. Leverage points: places to intervene in a system. Hartland: The Sustainability Institute, 1997. Disponível em: < http://www.sustainer.org/pubs/LeveragePoints.pdf>. Acesso em: abr. 2008.

MEADOWS, Donella H. Limites do Crescimento. São Paulo: Editora Perspectiva, 1974.

MEADOWS, Donella H; RANDERS, Jorgen; MEADOWS, Dennis. Limites do Crescimento: A Atualização de 30 Anos. Rio de Janeiro: Qualitymark, 2008.

MELO, Marcus André. Crise federativa, guerra fiscal e "hobbesianismo municipal" efeitos perversos da descentralização? São Paulo em perspectiva, v. 10, n. 3, 1996.

MENDES, Rosilda; BÓGUS, Cláudia Maria; AKERMAN, Marco. Agendas urbanas intersetoriais em quatro cidades de São Paulo. Saúde e Sociedade, v. 13, n. 1, p.47-55, jan.-abr. 2004.

MILARÉ, Édis. Direito do Ambiente: doutrina, jurisprudência, glossário. São Paulo: Revista dos Tribunais, 2004.

MINAYO, Cecília de Souza. O desafio do conhecimento: pesquisa qualitativa em saúde. São Paulo: Ucitec, 2008.

$\mathrm{MOL}$, Arthur. The environmental movement in na era of ecological modernisation. Geoforum, v. 31, p. 45-56, 2000. 
MONTEIRO, Maria Gabriela; FLEURY, Sonia. Democracia deliberativa nas gestões municipais de saúde: um olhar sobre a importância dos conselhos municipais de saúde nas gestões. Saude em Debate, Rio de Janeiro, v. 30, n. 73/74, p.219-233, mai./dez. 2006.

MONTERO, Sergio Graf et al. Collaborative governance for sustainable water resources management: the experience of the Inter-municipal Initiative for the Integrated Management of the Ayuquila River Basin, Mexico.

Environment and Urbanization, v. 18, n.2, p. 297-313, out. 2006. DOI: 10.1177/0956247806069602.

MORAIS, Mário Maurici de Lima. A gestão pública e a transformação da auto-imagem da comunidade: estudo de caso de Santo André (SP) 19972000. 2004. Dissertação (Mestrado em administração) - Universidade Municipal de São Caetano do Sul, São Caetano do Sul, 2004.

NUNES, Marcela Ricome. COMUGESAN. In: Relatório de pesquisa, parte integrante do projeto MEGA - Avaliação Estratégica do Processo de Implementação das Políticas de Desenvolvimento e Meio Ambiente no Município de Santo André - SP. 2009.

OSMONT, Annick. La Governance: concept mou, politique ferme. Les Annales de la Recherche Urbaine, Paris, n. 80-81, p.19-27, dez. 1998.

PHILIPPI JR. Arlindo; BRUNA, Gilda C.. Política e Gestão Ambiental. In: PHILIPPI JR. Arlindo; ROMERO, Marcelo A.;BRUNA, Gilda C.. Curso de gestão ambiental. Barueri, SP: Manole, 2004. p. 657-714.

PINHO, José Antônio G. de e SANTANA, Mercejane W. Inovação na gestão pública no Brasil: uma aproximação teórico-conceitual. In: ENCONTRO NACIONAL DA ASSOCIAÇÃO NACIONAL DE PÓS-GRADUAÇÃO E PESQUISA EM ADMINISTRAÇÃO, 22, 1988, Foz do Iguaçu. Anais...: Rio de Janeiro: ANPAD, 1988. p.1-12.

PLATEAU-MONT-ROYAL. Le budget participative du Plateau: guide du rèsidant. Montréal, 2008.

PONTUAL, Pedro. ARAÚJO, Laudicéia. Uma agenda da participação popular para os próximos anos. in: TEIXEIRA, Ana Claudia Chaves, (Org.). Os sentidos da democracia e da participação. São Paulo: Instituto, Pólis, 2005. 
PROYECTO INCLUIR (Cord.) El Presupuesto Participativo como instrumento de lucha contra la exclusión social y territorial. Venecia: Centro Internacional de Gestión Urbana, 2006.

PUTNAM, Robert D. Comunidade e Democracia: a experiência da Itália moderna. Rio de Janeiro: FGV, 2006.

RAMOS-PINTO, P. Social capital as a capacity for collective action, Assessing social capital: concept, policy, practice, Cambridge Scholars Press, Newcastle, 2006.

REPENTE -- participação popular na construção do poder local. Instituto polis, n. 10, dez. 2000.

ROGERS, Richard. Cidades para um Pequeno Planeta. Barcelona: Gustavo Gili, 2001.

ROLNIK, Raquel; SOMEKH, Nadia. Governar as metrópoles: dilemas da descentralização. In: ENCONTRO ANUAL DA ANPOCS, 25, 2001, Caxambu. Anais... Caxambu: [s.n.], 2001.

SACHS, Ignacy. Desenvolvimento includente, sustentável, sustentado. Rio de Janeiro: Garamond, 2004.

SANTO ANDRÉ. Prefeitura Municipal. Decreto no 15.236, de 28 de junho de 2005. Aprova o Regimento Interno do Conselho Municipal de Política Urbana - CMPU, criado pela Lei no 8.696, de 17 de dezembro de 2004. Disponível em <http://www.santoandre.sp.gov.br>. Acesso em: 6 mai. 2008.

SANTO ANDRÉ. Prefeitura Municipal. Disponível em:

<http://www.santoandre.sp.gov.br>. Acesso em: nov. 2009.

SANTO ANDRÉ. Prefeitura Municipal. Lei no 7.733 de 14 de outubro de 1998. Dispõe sobre Política Municipal de Gestão e Saneamento Ambiental e dá outras providências. Disponível em <http://www.santoandre.sp.gov.br>. Acesso em: 6 mai. 2008. 
SANTO ANDRÉ. Prefeitura Municipal. Lei no 8.696 de 17 de dezembro de 2004. Institui o novo Plano Diretor do município de Santo André, nos termos do artigo 182 da Constituição Federal, do capítulo III da Lei no 10.257, de 10 de julho de 2001 - Estatuto da Cidade - e do Título V, Capítulo III, da Lei Orgânica do Município de Santo André. Disponível em <http://www.santoandre.sp.gov.br>. Acesso em: 6 mai. 2008.

SANTO ANDRÉ. Prefeitura Municipal. Lei Orgânica (1990). Lei Orgânica de Santo André. Santo André, SP: Câmara. Disponível em <http://www.santoandre.sp.gov.br>. Acesso em: 6 mai. 2008.

SANTO ANDRÉ. Prefeitura Municipal de Santo André. Regimento Interno do Orçamento Participativo. 2008. Disponível em <http://www.santoandre.sp.gov.br>. Acesso em: 12.mar.2008.

SANTORO, Paula. Relação entre políticas territoriais e reestruturação econômica: a Operação Urbana Eixo Tamanduatehy, Santo André - São Paulo, 2005. Disponivel em:< http://direitoacidade.org.br/download/177.pdf> . Acesso em: fev. 2009.

SANTOS JUNIOR. Orlando Alves dos. Democracia e governo local: dilemas e reforma municipal no Brasil. Rio de Janeiro: Revan, 2001.

SATTERTHWAITE, David. The Scale of Urban Change Worldwide 1950-2000 and its Underpinnings. London: International Institute for Environment and Development, 2005. Disponível em: <WWW.iied.org/urban/urbanchange.html>. Acesso em: jun.2010.

SEMASA, Saneamento Ambiental de Santo André. Regimento para o Conselho Municipal de Gestão e Saneamento Ambiental de Santo André. 2004. Disponível em:< http://www.semasa.sp.gov.br/scripts/display.asp?idnot=506> . Acesso em: 29.maio.2010.

SILVA, Alessandra Ximenes; CRUZ, Eliane Aparecida; MELO, Verbena. A importância estratégica da informação em saúde para o exercício do controle social. Ciência \& Saúde Coletiva, v. 12, n. 3, p. 683-688, 2007.

SIRKIS, Alfredo. Cidade. In: TRIGUEIRO, André (org). Meio ambiente no século 21. Rio de janeiro: Sextante, 2003. 
SOMEKH, Nadia; CAMPOS NETO, Candido Malta. Desenvolvimento local e projetos urbanos. Arquitextos, São Paulo, 05.059, Vitruvius, abr. 2005.

Disponivel em:

<http://www.vitruvius.com.br/revistas/read/arquitextos/05.059/470>.

Acesso em: out. 2009.

SOUAMI, Taoufik. Participer à la gouvernance. Les Annales de la

Recherche Urbaine, Paris, n. 80-81, p. 163-171, dez. 1998.

SOUZA, Celina. Políticas Públicas: uma revisão da literatura. Sociologias, Porto Alegre, ano 8, n. 16, p. 20-45, jul.-dez. 2006,

SPPA. Subprefeitura de Paranapiacaba e Parque Andreense. Regimento Interno do Conselho de Representantes de Paranapiacaba e Parque Andreense, 2001?.

STOKER, Gerry. Governance as theory five propositions. Oxford: UNESCO, 1998.

TATAGIBA, Luciana. Os conselhos gestores de políticas públicas.

DAGNINO, Evelina (Org.). Sociedade civil espaços públicos no Brasil. São Paulo: Paz e Terra, 2002.

TEIXEIRA, Elenaldo Celso. Conselhos de políticas públicas: Efetivamente uma nova institucionalidade participativa?. In: CARVALHO, Maria do Carmo; TEIXEIRA, Ana Claudia (Org.). Conselhos gestores de políticas públicas. São Paulo: Pólis, 2000. p. 97-120.

TEIXEIRA, Elenaldo. Organização da sociedade civil e poder público. Teoria e Sociedade, número especial, p. 72-93, mar. 2005.

TONELLA, Celene. Poder local e políticas públicas: o papel dos conselhos gestores. Maringá, PR: Eduem, 2006.

TÓTORA, Silvana. CHAIA, Vera. Conselhos Municipais: descentralização, participação e limites institucionais. Cadernos Metrópole, n. 8, p. 59-86, $2^{\circ}$ sem. 2002.

UN HABITAT. The Habitat Agenda Goals and Principles, Commitments and the Global Plan of Action. 1996 
VOJNOVIC, Igor. Advancing towards urban sustainability: the pursuit of equity. No prelo. s/d.

WAMPLER, Brian. A difusão do Orçamento Participativo brasileiro: "boas práticas" devem ser promovidas? Opinião Pública, Campinas, v. 14, n. 1, p. 65-95, jun. 2008.

WAMPLER, Brian. Participatory budgeting in Brasil: contestarion, cooperation and accountability. Pensilvania: The Pennsilvania State University Press, 2007.

WILLARD, Terri. Social Networking and Gevernance for Sustainable Development. Winnipeg, CA: International Institute for Sustainable Development (IISD), 2009. Disponível em:

<http://www.iisd.org/pdf/2009/socialnetgov.pdf>. Acesso em: dez.2009.

ZMITROWICZ, Witold; BISCARO, Cibele. A organização administrativa do município e o orçamento municipal. Texto técnico. São Paulo: Escola Politécnica da USP - Departamento de Engenharia de Construção Civil, 1998. (TT/PCC/20). 



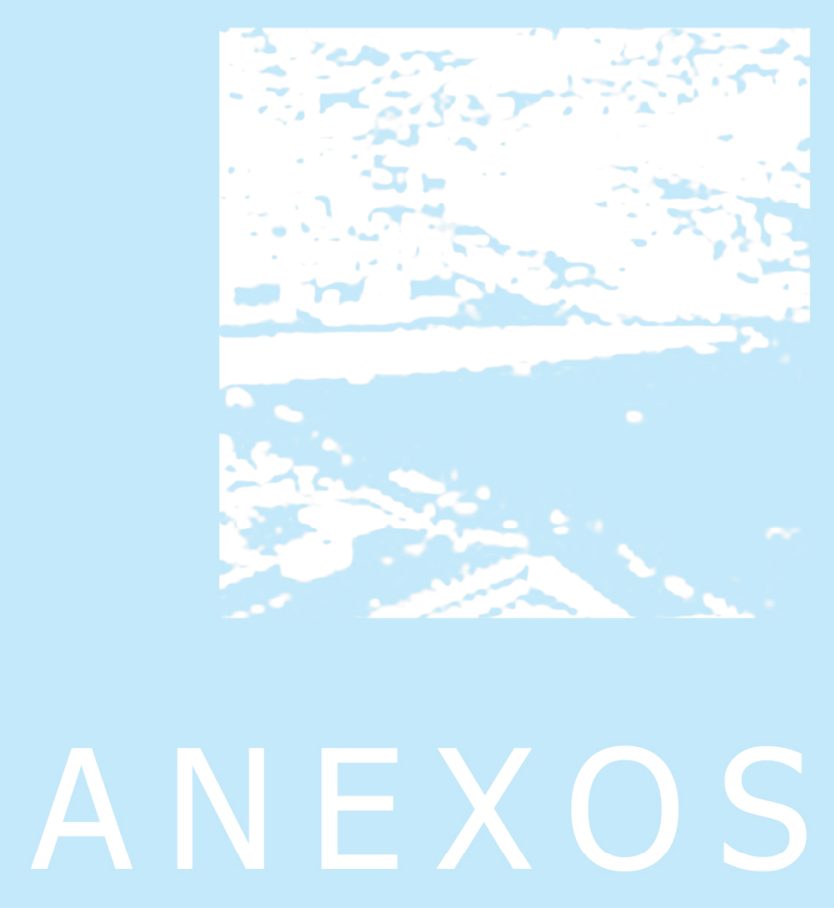





\section{ANEXO A - TERMO DE CONSENTIMENTO ESCLARECIDO}

$\mathrm{Eu}$,

aceito participar

da pesquisa para qual fui convidado (a), contribuindo com um entrevista, parte da pesquisa intitulada "Avaliação Estratégica do Processo de Implementação da Política de Desenvolvimento e Meio Ambiente no Município de Santo André", financiado pela Fundação de Amparo à Pesquisa do Estado de São Paulo - FAPESP e realizado na Faculdade de Saúde Pública da Universidade de São Paulo - FSP/USP em parceria com a Prefeitura Municipal de Santo André - SP, de responsabilidade do Prof. D.r Arlindo Philippi Jr.

Sei que minha participação é livre, não obrigatória, podendo ser interrompida por minha decisão a qualquer momento, sem qualquer prejuízo.

Assinatura:

Data://

Esta pesquisa em Políticas Públicas visa contribuir para o desenvolvimento e proposição de Metodologia de Avaliação Estratégica de Processo de Gestão Ambiental para implementação de Políticas Públicas, e sua aplicação no Município de Santo André, como estímulo à implementação de sistemática de avaliação de políticas públicas socioambientais na região como todo. Desse modo, como pesquisador, comprometo-me tanto a devolver os resultados e conclusões obtidos ao final da pesquisa, quanto a garantir o anonimato associado ao conteúdo da entrevista.

Para qualquer informação adicional terei disponível para contato o telefone:

(11) 30617712 R224

Professores Responsáveis: Prof. Dr. Arlindo Philippi Jr e Prof. Dr. Tadeu Fabrício Malheiros

Pesquisador:

Comitê de Ética em Pesquisa - Faculdade de Saúde Pública da USP

Av. Dr. Arnaldo, 715 - térreo - Cerqueira César - CEP: 01246-904 - São Paulo

Fone: 3061-7779/7742 e-mail: coep@fsp.usp.br 


\section{ANEXO B - QUESTIONÁRIO PARA ENTREVISTA COM OS GESTORES DE POLÍTICAS PÚBLICAS DE SANTO ANDRÉ}

Entrevistador:

Entrevistado:

Instituição:

Data, hora e local:

Contato:

DOCUMENTOS:

- Organograma da instituição

- Quadro de funcionários com a formação dos mesmos e o tipo de vínculo

- Políticas, programas, planos e projetos da instituição em vigor ou em desenvolvimento completo ou síntese.

\section{ENTREVISTA:}

\section{Estrutura da Instituição:}

1. Quantos funcionários a instituição possui? Quantos deles são administrativos? Quantos são de carreira, cursado ou comissionados?

2. Qual o perfil das gerências ou diretores [formação e experiência]?

3. Como é a política de capacitação dos funcionários?

\section{Planos, Programas, Políticas e Projetos}

4. Classifique as políticas, planos, programas e projetos de acordo com o estágio de andamento em que se encontra. 


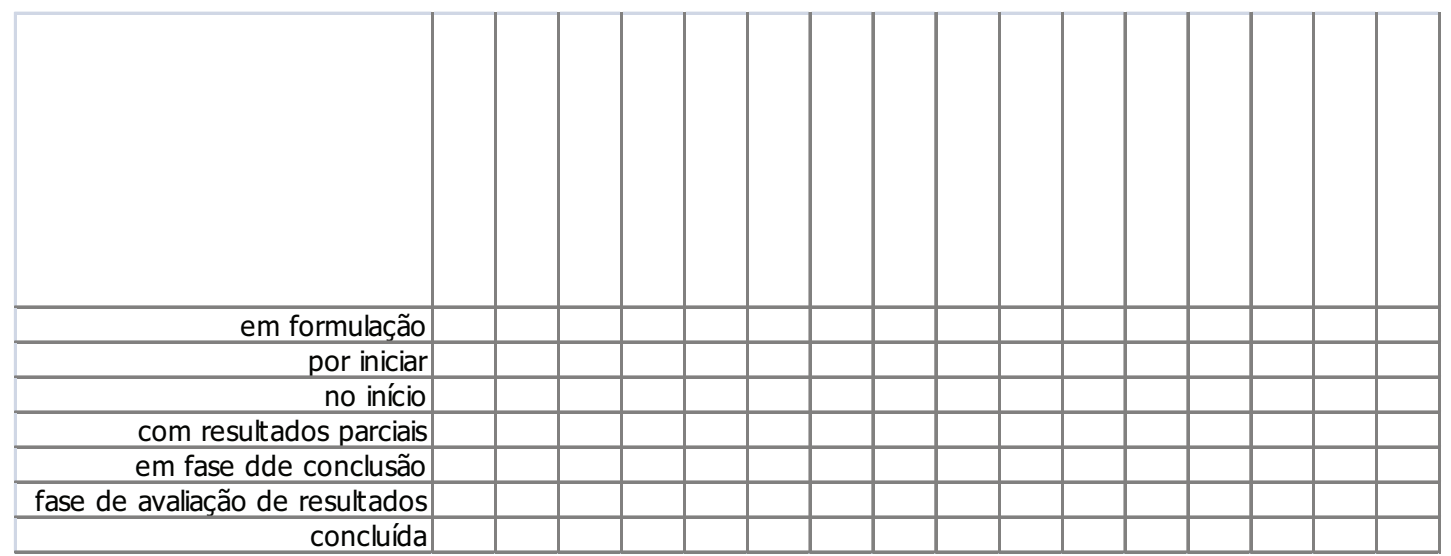

\section{Fase de Planejamento da Política Pública}

5. Como é o processo de formulação de uma PG ou PP?

6. Em que vocês se apóiam na tomada de decisão?

7. Como são conseguidos dos dados necessários para a tomada de decisão?

[ ] são dados prontos da própria instituição

[ ] são preparados na própria instituição para apoiar a tomada de decisão

[ ] são levantados especificamente para cada política

[ ] vêm de outras instituições

Quais:

[ ] vêm do departamento de indicadores sócio-econômicos

8. Como vocês consideram as políticas existentes no processo de formulação de uma nova política?

9. Como vocês consideram as metas do "Cidade Futuro" no processo de formulação de uma nova política?

10. O processo de formulação das políticas inclui participação social?

[ ]não

Sim, por meio de:

[ ]audiências

[ ]conferencias

[ ]conselhos, quais?

[ ]outros, quais?

11. As políticas passam por aprovação publica antes da aprovação da câmara?

[ ] $\operatorname{sim}$

[ ]não 
12. Como é feita a divulgação das políticas depois de aprovadas?

13. Como e qual é o envolvimento de técnicos na formulação das políticas

[ ]não há envolvimento DE TECNICOS;

[ ]são do corpo da instituição;

[ ]são contratados para projetos específicos;

[ ] ]pertencem à comunidade e são envolvidos no processo.

14. Qual o grau de autonomia da instituição no processo de formulação de políticas?

15. Como chegaram a esta forma de formulação de políticas [sempre foi assim?]?

16. Indique cinco pontos fortes, em ordem de importância, do processo de formulação de políticas de sua instituição :

[1]

[2]

[3]

[4]

[5]

17. Indique cinco dificuldades principais, em ordem de importância, do processo de formulação de políticas de sua instituição:

[1]

[2]

[3]

[4]

[5]

18. Você considera o processo de formulação de políticas tranparente?

[ ] não

[ ] quase nunca

[ ] às vezes

[ ] quase sempre

[ ] sempre

\section{Fase de execução decorrente da política Pública}

19. Como é o processo de formulação de uma PG ou PP?

20. Em que vocês se apóiam em processo de decisão? 
21. Como são definidas as prioridades na implementação de políticas?

22. Como a variável ambiental se encaixa nestas prioridades?

23. Como é a atribuição de verbas e como são feitos os ajustes?

24. Como é feito o monitoramento dos PPP?

25. Com que freqüência o monitoramento é realizado?

26. De que forma as informações do monitoramento interferem no rumo e no andamento das políticas? 
27. As políticas costumam caminhar de acordo com os prazos estabelecidos?

[ ] não

[ ] quase nunca

[ ] às vezes

[ ] quase sempre

[ ] sempre

28. As políticas costumam ser implementadas ate a obtenção dos resultados propostos?

[ ] não

[ ] quase nunca

[ ] às vezes

[ ] quase sempre

[ ] sempre

29. Os resultados parciais das políticas, assim como seu andamento são divulgados com freqüência?

[ ] não

[ ] quase nunca

[ ] às vezes

[ ] quase sempre

[ ] sempre

30. Como são divulgados:

31. Por quem são divulgados?

32. Indique cinco pontos fortes, em ordem de importância, no processo de implementação de políticas de sua instituição:

[1]

[2]

[3]

[4]

[5] 
33. Indique cinco dificuldades principais, em ordem de importância, do processo de implementação de políticas de sua instituição:

[1]

[2]

[3]

[4]

[5]

34. Você considera o processo de implementação de políticas transparente?

[ ] não

[ ] quase nunca

[ ] às vezes

[ ] quase sempre

[ ] sempre

\section{MAIS}

35. Existem políticas multissetoriais? Quais e com quem?

36. Qual a relação com as outras instituições?

[ ] trabalham de maneira individual; quais

[ ] se apóiam quando necessário; quais

[ ] trabalham freqüentemente em conjunto; quais

[ ] sempre trabalham em conjunto; quais 


\section{ANEXO C - QUESTIONÁRIO PARA ENTREVISTAS COM OS CONSELHEIROS MUNICIPAIS}

1. Você pode me explicar qual o papel do Conselho na prática?

2. Quais são as suas atividades como conselheiro?

3. Nas reuniões do conselho surgem muitas idéias? ... Fale um pouco sobre isso.

4. As idéias que surgem nas reuniões são sempre consideradas?...

5. Na sua opinião, as decisões do conselho se tornam realidade no município? ... Por que?

6. Você pode me explicar o caminho que uma idéia surgida no conselho percorre até virar realidade?

7. Você acompanha se as idéias aceitas são de fato implantadas? (se sim)...Como você acompanha?

8. Como são negociadas as diversas questões dentro do conselho?

9. Pela sua experiência, quais são as principais vantagens decorrentes da existência do conselho?

10. Quais são as principais dificuldades para o funcionamento do Conselho?

11. Você acha que os conselheiros são suficientemente informados para participar do conselho?

12. Como você se mantém informado?

13. Que tipo de informação você acha que deveria receber para melhorar a qualidade da sua atuação no conselho?

14. De que forma você acha que estas informações poderiam chegar até você?

15. Na sua opinião, existe uma diferença de atuação entre os conselheiroas que são funcionários e gestores públicos e os da sociedade civil?

16. Na sua opinião, o Conselho leva em consideração os aspectos ambientais no momento das decisões? ... Poderia explicar?

17. Quais as principais dificuldades para a inserção das questões ambientais no Conselho?

18. Na sua opinião, qual a importância do Conselho na Política Ambiental de Santo André?

19. Na sua opinião, o que é desenvolvimento sustentável?

20. Você acha que os debates dentro do conselho consideram Desenvolvimento Sustentável 
Arlindo Philippi Junior concluiu o doutorado em Saúde Pública pela Universidade de São Paulo em 1988. E Professor Titular da Universidade de São Paulo, Pesquisador USP, FAPESP, CAPES e CNPq. Exerce atualmente a função de Pró-Reitor Adjunto de Pós-Graduação da USP, Coordenador de Área Interdisciplinar da CAPES e é membro titular do Conselho Técnico Científico de Ensino Superior (CTC-ES) da CAPES. Publicou 32 artigos em periódicos especializados e 198 trabalhos em anais de eventos. Possui 96 capítulos de livros e 28 livros publicados. Possui 179 itens de produção técnica. Participou de 426 eventos no no Brasil e exterior. Orientou 15 dissertações de mestrado, 10 teses de doutorado e 2 teses de pósdoutorado nas áreas de Política, Planejamento e Gestão Ambiental, Engenharia Sanitária e Ambiental, Planejamento Urbano e Regional, e Saúde e Ambiente. Participou de 48 projetos de pesquisa, entre os quais, coordenou 7 destes nos ultimos 5 anos. Atua em Política, Planejamento e Gestão Ambiental. Em suas atividades profissionais interagiu com 189 colaboradores em co-autorias de trabalhos científicos. Em seu currículo Lattes os termos mais frequentes na contextualização da produção científica e tecnológica são: Política, Planejamento e Gestão Ambiental, Planejamento Urbano e Regional, Saneamento Ambiental, Controle Ambiental, Resíduo Sólido, Saúde Ambiental e Indicadores de Sustentabilidade.

(Texto informado pelo autor)

Última atualização do currículo em 21/06/2010

Endereço para acessar este CV:

http://lattes.cnpq.br/5256254337538114
Certificado

pelo autor em

21/06/10

Dados pessoais

Nome Arlindo Philippi Jr

Nome em citações PHILIPPI JR, Arlindo bibliográficas

Sexo Masculino

Endereço profissional Universidade de São Paulo, Faculdade de Saúde Pública, Departamento de Saúde Ambiental. Dr. Arnaldo 715 Cerqueira Cesar 01246-904 - Sao Paulo, SP - Brasil Telefone: (11) 30667712 Fax: (11) 30667117

URL da Homepage: www.fsp.usp.br

Formação acadêmica/Titulação

2002 Livre-docência

Universidade de São Paulo, USP, Brasil.

Título: O Impacto da Capacitação em Gestão Ambiental, Ano de obtenção: 2002.

Palavras-chave: Gestão Ambiental; Capacitação Profissional; Meio Ambiente.

1989 - 1990 Pós-Doutorado

Massachusetts Institute of Technology.

Grande área: Ciências Sociais Aplicadas / Área: Planejamento Urbano e Regional / Subárea: Fundamentos do Planejamento Urbano e Regional.

1982 - 1988 Doutorado em Saúde Pública (Conceito CAPES 5) .

Universidade de São Paulo, USP, Brasil.

Título: Controle de Poluição Ambiental: Implantação de Sistema de Financiamento, Ano de Obtenção: $198 \varepsilon$ Orientador: Walter Engracia de Oliveira.

Grande área: Engenharias / Área: Engenharia Sanitária / Subárea: Controle e Gestão Ambiental.

1973 - 1979 Mestrado em Saúde Pública (Conceito CAPES 5). Universidade de São Paulo, USP, Brasil.

Título: Sistema de Resíduos Sólidos: Coleta e Transporte no Meio Urbano, Ano de Obtenção: 1979. Orientador: Walter Engracia de Oliveira.

Grande área: Engenharias / Área: Engenharia Sanitária / Subárea: Saneamento Básico / Especialidade: Gerenciamento de Resíduos.

1973 - 1973 Especialização em Higiene, Segurança e Medicina do Trabalho . Universidade de São Paulo, USP, Brasil. 


\section{Paula Raquel da Rocha Jorge Vendramini}

Possui graduação em Arquitetura e Urbanismo pela Universidade de São Paulo (1990) e mestrado em Arquitetura e Urbanismo pela Universidade Presbiteriana Mackenzie (2005).

Atualmente é aluna da Universidade de São Paulo e professor visitante da Universidade Presbiteriana Mackenzie. Tem experiência na área de Arquitetura e Urbanismo, com ênfase em Adequação Ambiental, atuando principalmente nos seguintes temas: desenvolvimento sustentável, sustentabilidade urbana, cidades sustentáveis, apls - arranjos produtivos locais e ecologia urbana.

(Texto informado pelo autor)

Última atualização do currículo em 06/08/2010

Endereço para acessar este CV:

http://lattes.cnpq.br/4297763895930396

Certificado

pelo autor em

$06 / 08 / 10$

Dados pessoais

Nome Paula Raquel da Rocha Jorge Vendramini

Nome em citações JORGE, Paula R.

bibliográficas

Sexo Feminino

Endereço profissional Universidade de São Paulo, Faculdade de Saúde Pública.

Av Prof Arnaldo, 715,

Pinheiros

01246-904 - Sao Paulo, SP - Brasil

Telefone: (11) 30617118 Ramal: 224

URL da Homepage: http://www.fsp.usp.br

Formação acadêmica/Titulação

2006 Doutorado em andamento em Saúde Pública (Conceito CAPES 5).

Universidade de São Paulo, USP, Brasil.

com período sanduíche em Mcgill University(Orientador:prof. Dr. David Brown )

Título: Indiadores de Governaça Municipal para o Desenvolvimento Sustentável, Orientador: Arlindo Philipk Palavras-chave: Desenvolvimento Sustentável; Governança Municipal; Indicadores.

Grande área: Ciências Sociais Aplicadas / Área: Arquitetura e Urbanismo / Subárea: Projeto de Arquitetura e

Urbanismo / Especialidade: Planejamento e Projeto do Espaço Urbano.

Grande área: Ciências da Saúde / Área: Saúde Coletiva / Subárea: Saúde Pública / Especialidade: Instrument Gestão Ambiental.

Setores de atividade: Produtos e Serviços Voltados Para A Defesa e Proteção do Meio Ambiente, Incluindo O Desenvolvimento Sustentado.

2003 - 2005 Mestrado em Arquitetura e Urbanismo (Conceito CAPES 4) .

Universidade Presbiteriana Mackenzie, MACKENZIE, Brasil.

Título: Meio Urbano e Sustentabilidade, Ano de Obtenção: 2005.

Orientador: (9) Profa Dra Gilda Collet Bruna.

Bolsista do(a): Coordenação de Aperfeiçoamento de Pessoal de Nível Superior,

Palavras-chave: Sustentabilidade Urbana; Meio Ambiente Urbano; Cidades Sustentáveis.

Grande área: Ciências Sociais Aplicadas / Área: Arquitetura e Urbanismo / Subárea: Tecnologia de Arquitetur Urbanismo / Especialidade: Adequação Ambiental.

Grande área: Ciências Sociais Aplicadas / Área: Arquitetura e Urbanismo / Subárea: Fundamentos de Arquitet Urbanismo / Especialidade: Teoria do Urbanismo.

Setores de atividade: Desenvolvimento Urbano; Planejamento e Gestão das Cidades, Inclusive Política e

Planejamento Habitacional; Produtos e Serviços Voltados Para A Defesa e Proteção do Meio Ambiente, Incluit Desenvolvimento Sustentado.

1986 - 1990 Graduação em Arquitetura e Urbanismo

Universidade de São Paulo, USP, Brasil.

Título: Macro Zoneamento Regional do Litoral Norte e Regiões Serranas do Vale do Paraíba Paulista.

Orientador: Prof Dra. Gilda Collet Bruna. 



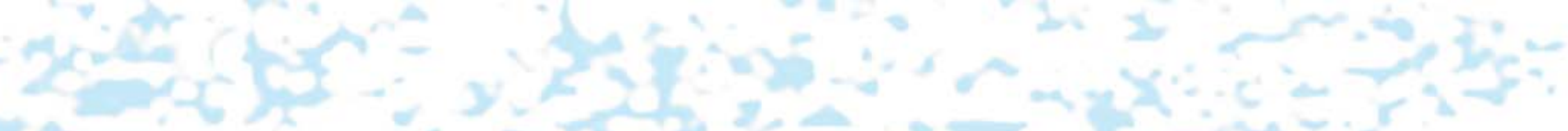

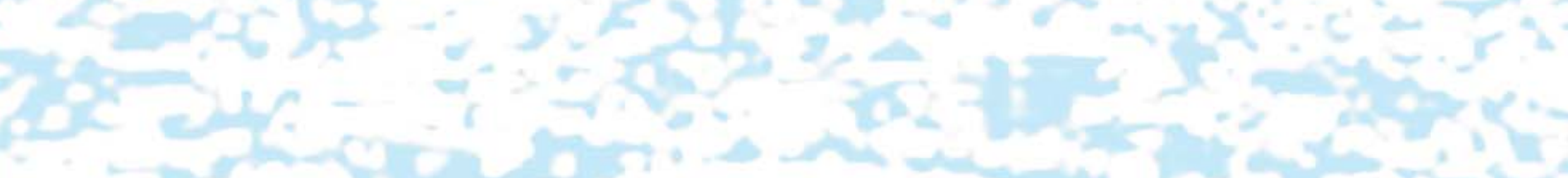

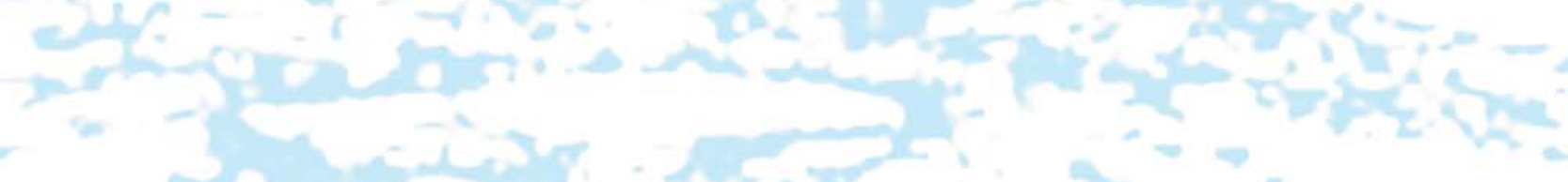

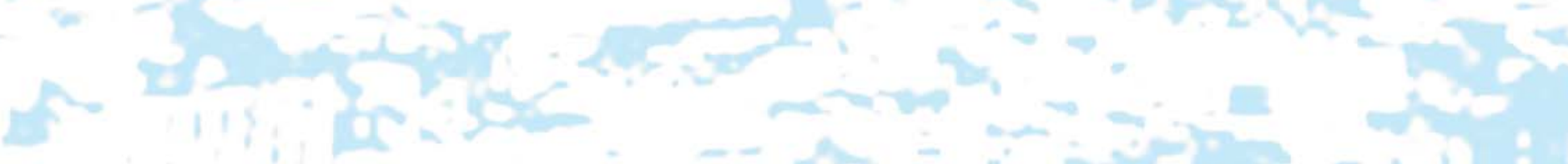

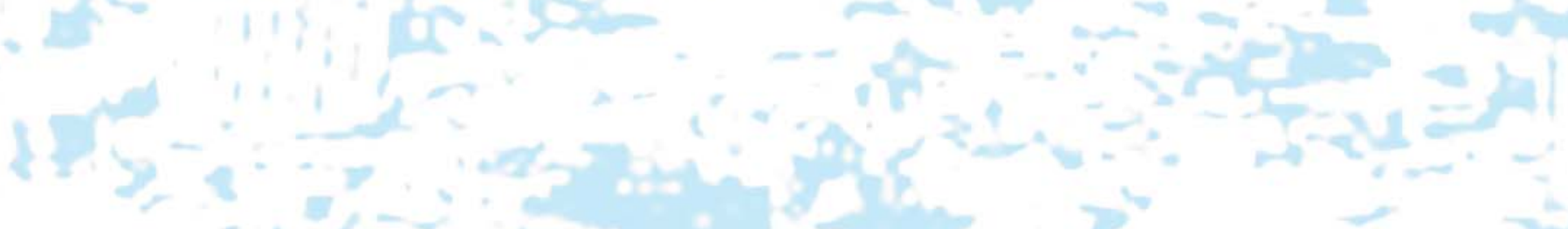

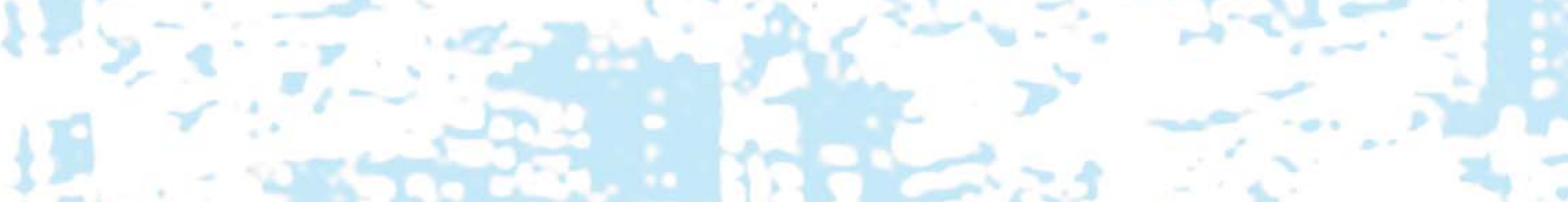
is of hom

ar

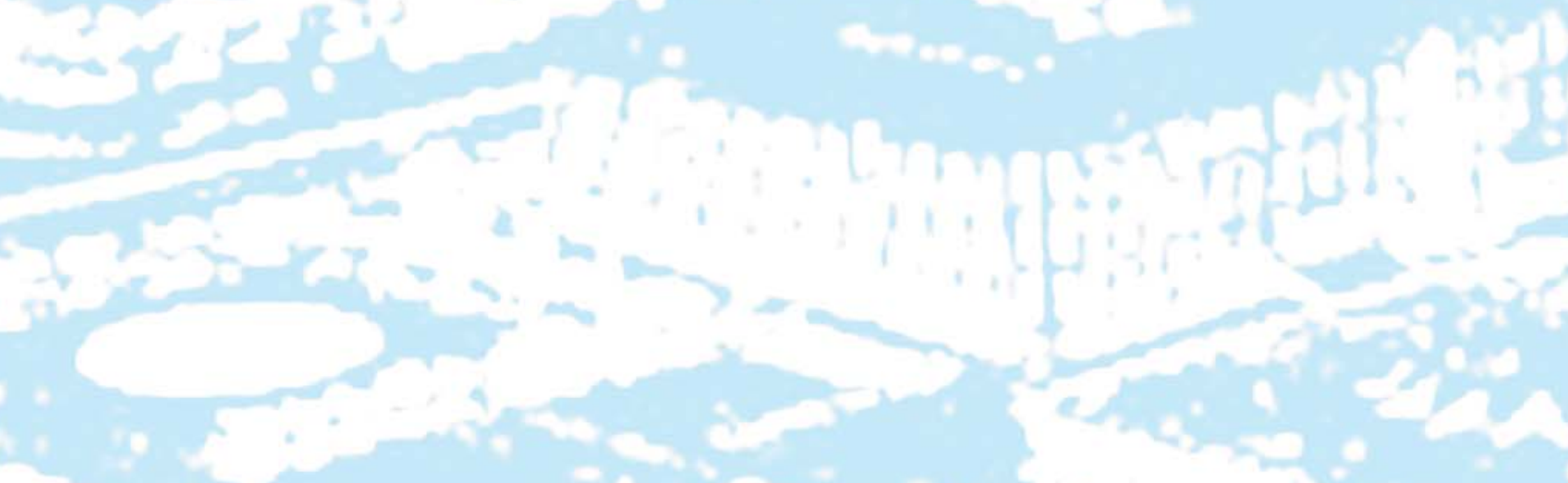

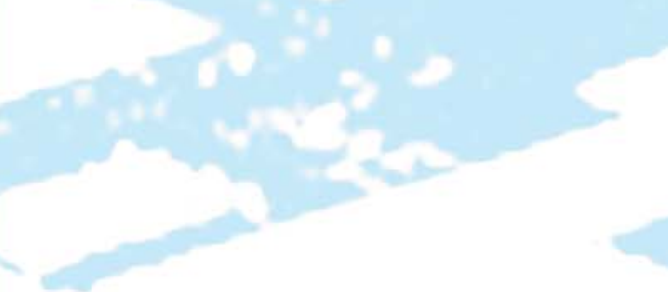

30
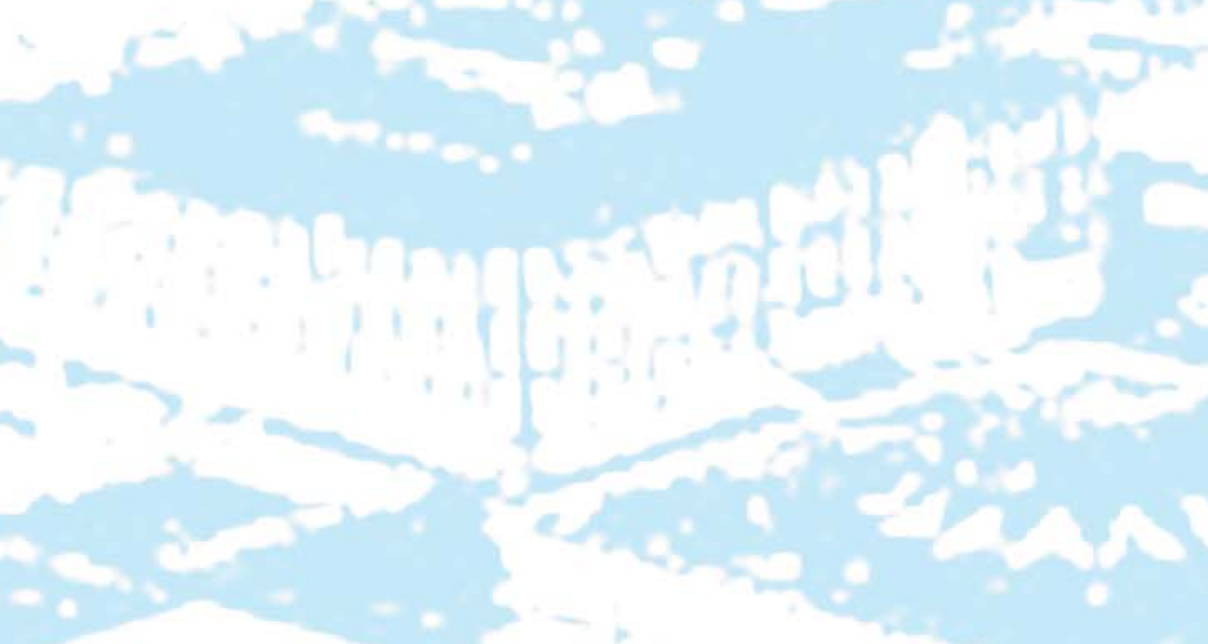

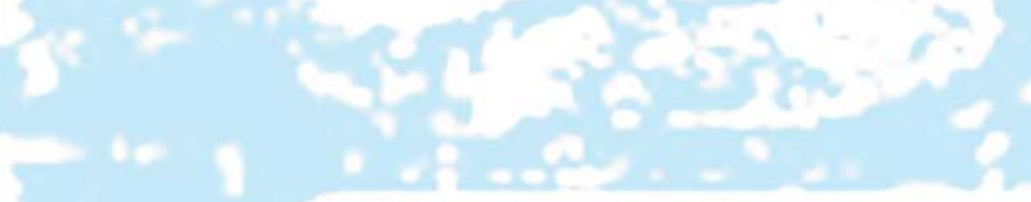

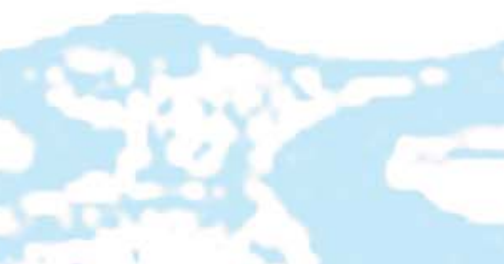

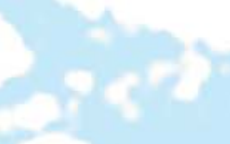

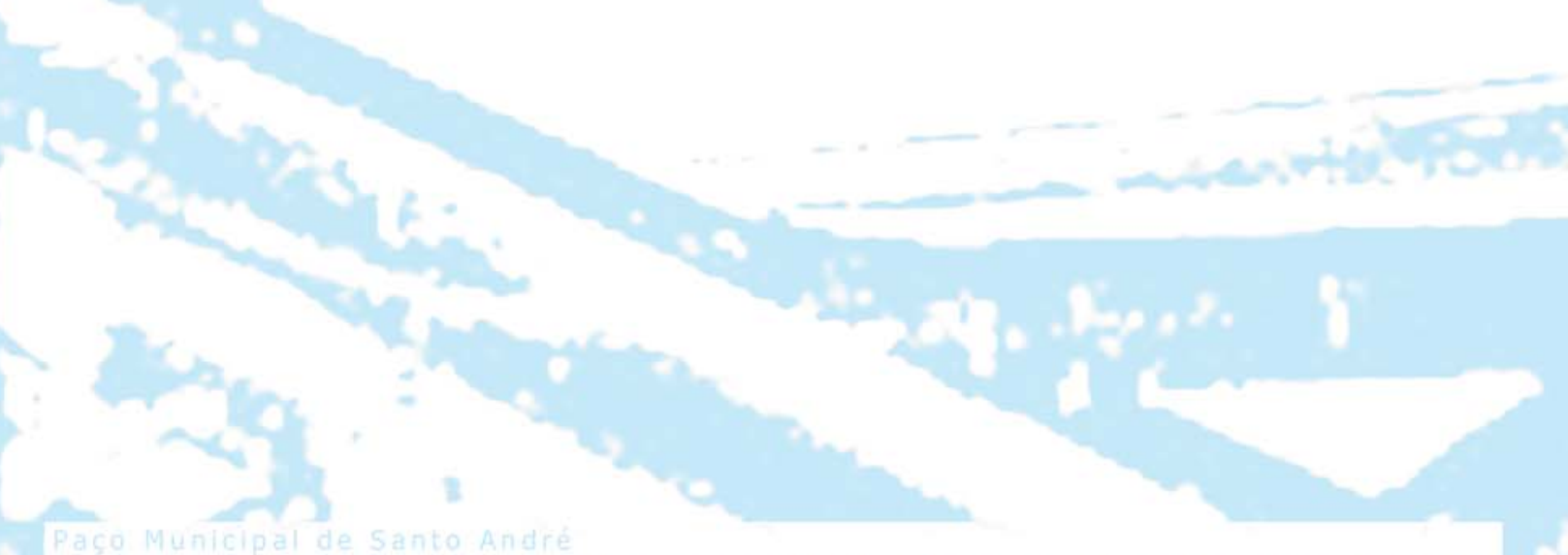

anaters 


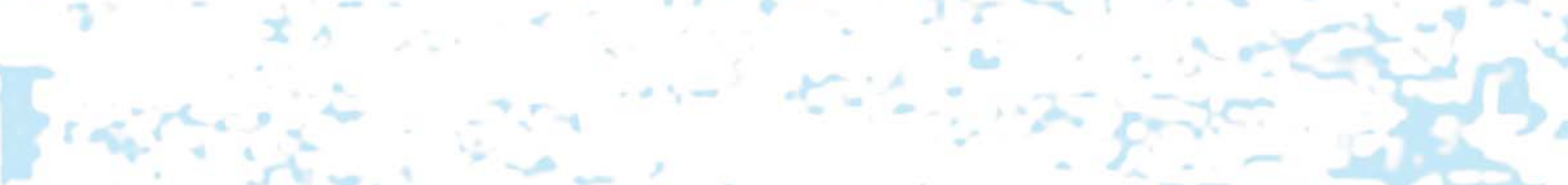

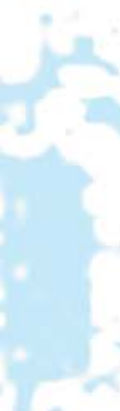

to

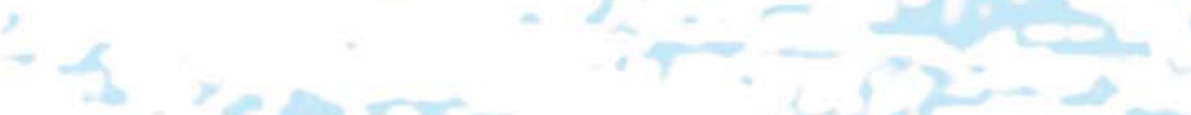
$\therefore \rightarrow-2,3 x-$

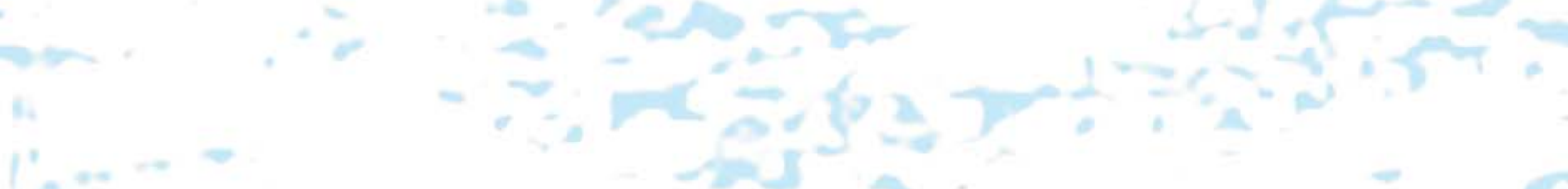

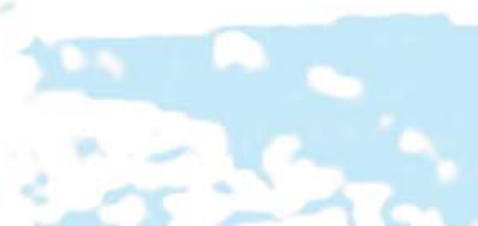

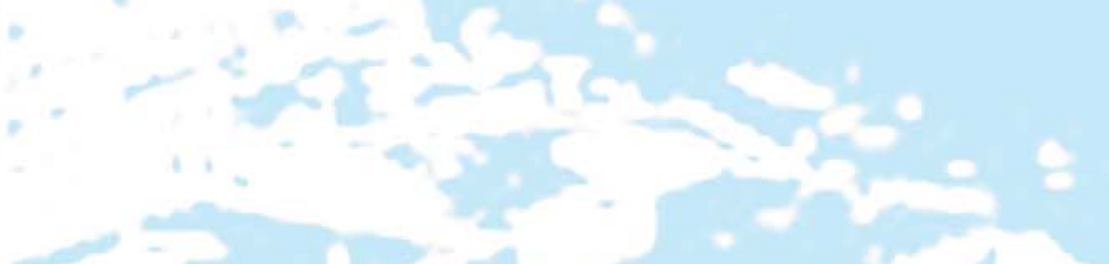

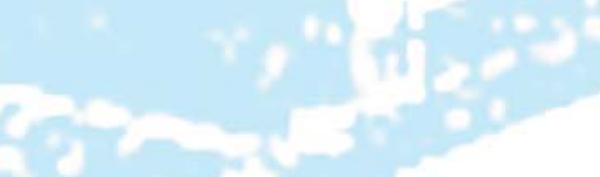

208

है

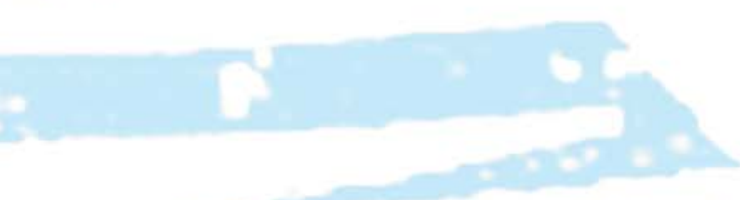

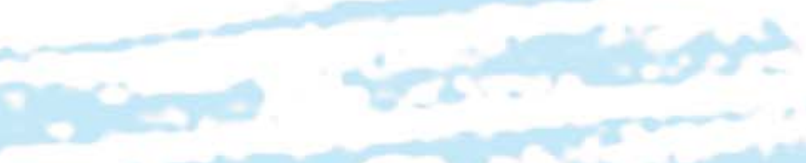

(a) tactit (x) 
Departamento de Saúde Ambiental

Faculdade de Saúde Pública Universidade de São Paulo 